
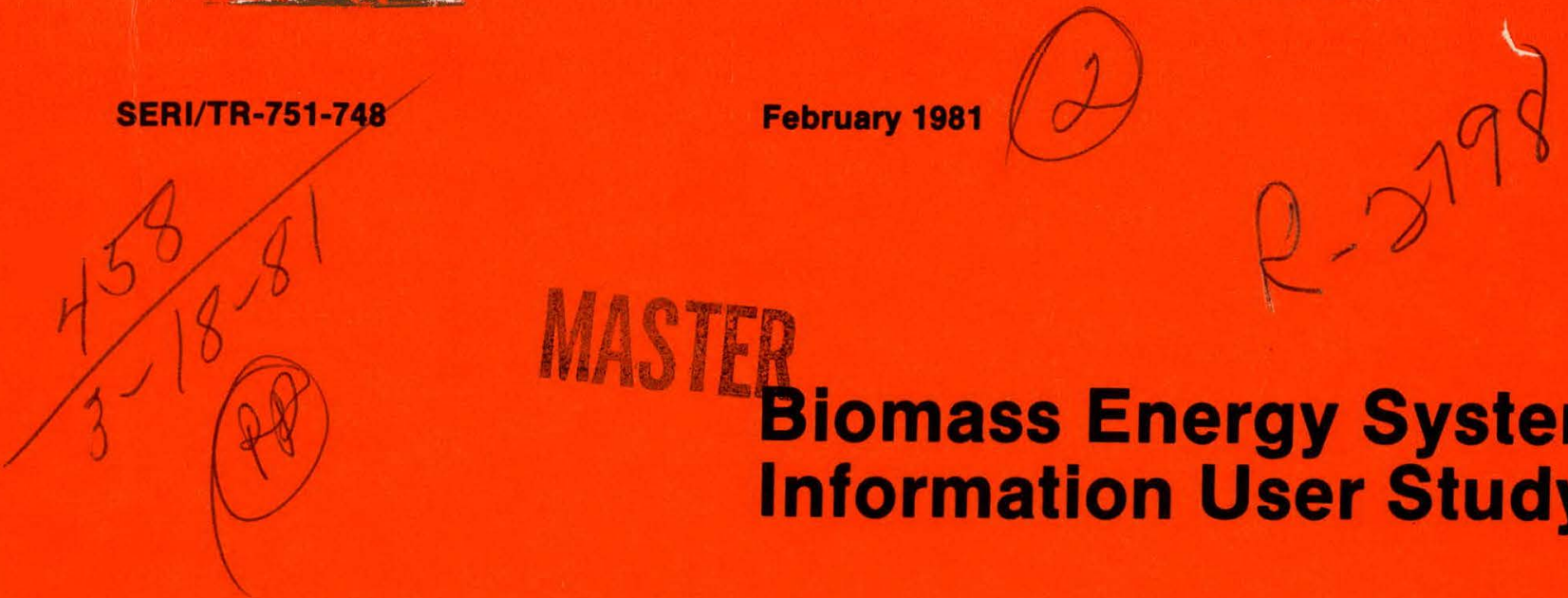

\title{
MASTER \\ Biomass Energy Systems Information User Study
}

\author{
W. W. Belew \\ B. L. Wood \\ T. L. Marle \\ C. L. Reinhardt
}
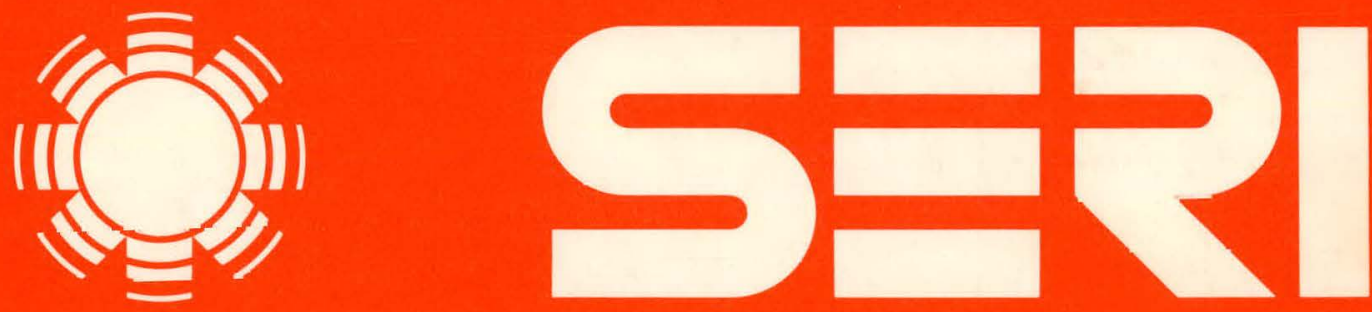

Solar Energy Research Institute

A Division of Midwesl Research Instıtute

1617 Cole Boulevard

Golden, Colorado 80401

Operated for the

U.S. Department of Energy

under Contract No. EG-77-C-01-4042 


\section{DISCLAIMER}

This report was prepared as an account of work sponsored by an agency of the United States Government. Neither the United States Government nor any agency Thereof, nor any of their employees, makes any warranty, express or implied, or assumes any legal liability or responsibility for the accuracy, completeness, or usefulness of any information, apparatus, product, or process disclosed, or represents that its use would not infringe privately owned rights. Reference herein to any specific commercial product, process, or service by trade name, trademark, manufacturer, or otherwise does not necessarily constitute or imply its endorsement, recommendation, or favoring by the United States Government or any agency thereof. The views and opinions of authors expressed herein do not necessarily state or reflect those of the United States Government or any agency thereof. 


\section{DISCLAIMER}

Portions of this document may be illegible in electronic image products. Images are produced from the best available original document. 


\section{DISCLAIMER}

This report was prepared as an account of work sponsored by an agency of the United States Government. Neither the United States Government nor any agency Thereof, nor any of their employees, makes any warranty, express or implied, or assumes any legal liability or responsibility for the accuracy, completeness, or usefulness of any information, apparatus, product, or process disclosed, or represents that its use would not infringe privately owned rights. Reference herein to any specific commercial product, process, or service by trade name, trademark, manufacturer, or otherwise does not necessarily constitute or imply its endorsement, recommendation, or favoring by the United States Government or any agency thereof. The views and opinions of authors expressed herein do not necessarily state or reflect those of the United States Government or any agency thereof. 


\section{DISCLAIMER}

Portions of this document may be illegible in electronic image products. Images are produced from the best available original document. 


\author{
Printed in the United States of America \\ Available from: \\ National Technical Information Service \\ U.S. Depurtment of Commerse \\ 5285 Port Royal Roud \\ Springfield, VA 22161 \\ Price: \\ Microfiche $\$ 3.00$ \\ Printed Copy $\$ 10.75$
}

\begin{abstract}
NOTICE
This report was prepared as an account of work sponsorcd by the United States Government. Neither the United States nor the United States Department of Energy, nor any of their employees, nor any of their contractors, subcontractors, or their employees, makes any warranty, express or implied, or assumes any legal liability or responsibility for the accuracy, completeness or usefulness of any information, apparatus, product or process disclosed, or represents that its use would not infringe privately owned rights.
\end{abstract}


SERI/TR-751-748

UC CATEGORIES: UC- $\$ 1 a, 58 \mathrm{c}$

BIOMASS ENERGY SYSTEMS

INFORMATION USER STUDY

W. W. BELEW

B. L. WOOD

T. L. MARLE

C. L. REINHARDT

FEBRUARY 1981

PREPARED UNDER TASK No. $8420.11,1023.11$

\section{Solar Energy Research Institute}

A Division of Midwest Research Institute

1617 Cole Boulevard

Golden, Colorado 80401

Prepared for the

U.S. Department of Energy

Contract No. EG-77-C-01-4042

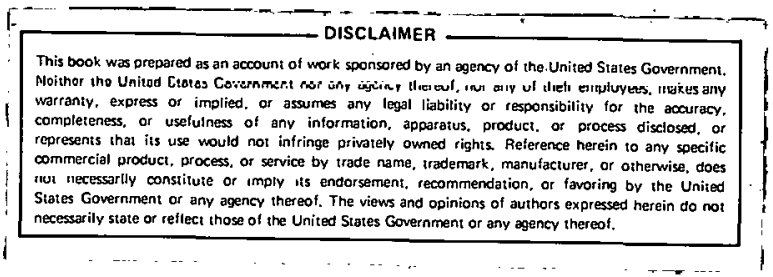




\section{THIS PAGE}

WAS INTENTIONALLY

LEFT BLANK 


\section{FOREWORD}

This document reports the results of a series of studies of users of biomass energy system information. It identifies specific biomass information user group needs, the priority of those needs, and methods of disseminating information to each group. This is one of a series of ten reports covering many different solar technologies. These results will play an integral part in the planning of new information products and data bases for the Solar Energy Information Data Bank (SEIDB).

This study was performed under Contract No. EG-77 C-01-4042, FY 1980 Task Number 8420.11.

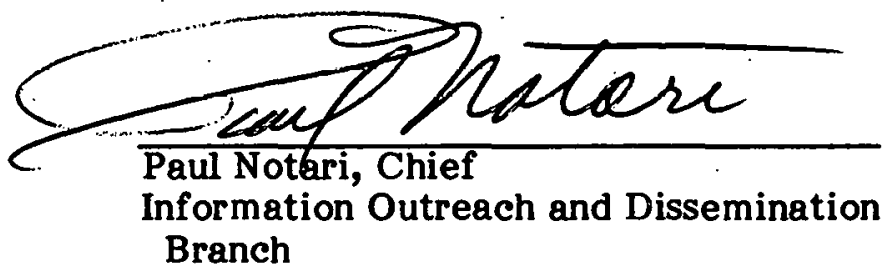

Approved for

SOLAR ENERGY RESEARCH INSTITUTE
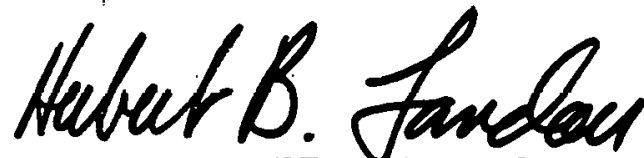

Herbert B. Landau, Manager Information Eystems Division 
THIS PAGE WAS INTENTIONALLY LEFT BLANK 


\section{ACKNOWLEDGMENTS}

The authors would like to thank the following for their valuable technical advice and review.

P. Bente, Jr.

The Bio-Energy Council

B. Berger

Biomass Energy Systems Division

U.S. Department of Energy

G. Diadone

Northeast Solar Energy Center

M. Hohmann

Mid-American Solar Energy Complex

B. Inman

Biomass Program Branch

SERI

T. Milne

Biomass Thermal Conversion and

Exploratory Research Branch

SERI

P. Reddy

Environmental and Social Impacts Group

SERI

J. Sanderson

Dynatech Research and Development Company

A. Stewart

Agriculture and Transportation Group

SERI

R. Villet

Biotechnology Research Branch

SERI. 
Blank

vi 


\section{BIOMASS ENERGY SYSTEMS \\ INFORMATION USER STUDY \\ MANAGEMENT SUMMARY}

This report describes the results of a series of telephone studies of potential users of information on biomass energy systems. These studies, part of a larger study covering many different solar technologies, identified:

- the types of information each group of information users needed, and

- the ways to get information to that group.

This biomass energy report is one of ten discussing the results of these studies.

\section{BACKGROUND}

The purpose of the overall study was to obtain baseline data about the information needs of the solar community. Very little previous work has been done in this area; the studies that have been done were generally restricted to solar heating and cooling of buildings. The present study is the only one known to investigate all of the following technological areas:

- Photovoltaics

- Passive Solar Heating and Cooling

- Active Solar Heating and Cooling

- Biomass Energy

- Solar Thermal Electric Power

- Industrial and Agricultural Process Heat

- Wind Energy

- Ocean Energy

- Solar Energy Storage

There have been a few previous studies which asked homeowners what solar information they needed, but this is the only known study to provide data on the solar information that such groups as researchers, manufacturers, architects, engineers, installers, lawyers, bankers, insurers, public interest groups, state energy offices, and agricultural extension agents themselves say they want.

The data from this study will be used along with other data to determine what new information products and services the Solar Energy Research Institute, (SERI) the Solar Energy Information Data Bank (SEIDB) Network, and the entire solar information outreach community should be preparing for and disseminating to the solar community. 


\section{STUDY CHARACTERISTICS}

Between 3 September 1979 and 13 October 1979 Market Opinion Research, Inc. of Detroit, Michigan-under subcontract to SERI-conducted telephone interviews with 86 distinct groups of solar information users taken from across the nine different technological areas. Approximately nine respondents were interviewed from each group. Interviews were based upon professionally reviewed and tested questionnaires that utilized a mixture of open-ended and closed-ended questions. The interviews took an average of 18 minutes to complete.

The respondents proved to be very cooperative. Considering the length and nature of the telephone interviews, it was surprising that only about $3 \%$ of the respondents terminated an interview or refused to be interviewed. This finding supported the interviewers' statements that the respondents were very interested in telling what they were doing in solar energy, in obtaining solar information, and in specifying what solar information would prove the most valuable.

\section{SAMPLE SZE}

Studies of 86 groups, each interested either in one of nine specific solar technologies or in solar energy in general, provided an extremely broad view of the information needs of the solar community. Although the sample size of only nine respondents per group was small, the data still proved to be adequate for planning purposes. It was possible to determine the information most important to the respondents and the best channel for dissemination. A variety of valid statistical tests were performed, both to compare the priorities a group gave to different information items and to compare the priorities different groups gave to the same item (see Section 2.3 and Appendix E).

\section{BIOMASS ENERGY GROUPS STUDIED}

The results of an earlier study identified the groups of information users constituting the biomass energy community [l] and determined the priority (to accelerate commercialization of solar energy) of getting information to each user group. In the current study only high-priority groups were included. Considerable effort (e.g.; library searches, phone calls, subcontractors) went into obtaining the names of people who were professionally involved with biomass energy. When the phone interviews were conducted, an elaborate screening process was used to guarantee that the potential respondent was truly involved in biomass energy. Respondents in the following 12 groups were queried about their need for information on biomass energy technologies:

- Federally Funded Researchers involved in the Production and Collection (P\&C) of biomass energy feedstocks,

- Nonfederally Funded Biomass P\&C Researchers,

- Federally Funded Researchers involved in the Conversion of biomass feedstock to energy,

- Nonfederally Funded Biomass Conversion Researchers,

- Representatives of Manufacturers of agricultural or forest Biomass Production and Collection Equipment, 
- Representatives of Manufacturers of Biomass Conversion Equipment,

- Representatives of State Forestry Offices who are interested in biomass energy,

- Private Foresters who have been involved with biomass energy,

- Forest Products Engineers and Consultants interested in biomass energy,

- Educators teaching college-level courses in biomass energy,

- Cooperative Extension Service (CES) County Agents who will be needing information on biomass energy, and

- Biomass Energy System Manàgers.

Several of the groups discussed in another report from this study [2] also indicated an interest in information on biomass energy (see Section 2.2.4).

\section{RESULTS}

In most cases the results from Federally Funded P\&C Researchers and Nonfederally Funded P\&C Researchers were similar. Thus, in the following tables the data for both groups of Biomass P\&C Researchers have been combined. Similarly, results for both the Federally Funded and the Nonfederally Funded groups of Biomass Conversion Researchers have been combined.

\section{Usefulness of General Types of Information}

The most important result obtained from this study was the identification of the biomass information categories ranked the most useful by each group of respondents (see Table S-1). Biomass respondents in almost every group gave high ratings to information on:

- The state of the art;

- Installation/operation costs;

- Cost/performance;

- Tax credits, grants, and incentives;

- Information sources; and

- Technical descriptions of systems.

Most notable, however, was the occasional wide range of rankings the groups gave to the information items. For example, even for some of these generally high-ranked items, there were several groups who ranked the item 10th or worse. Similarly for the generally low-ranked items, there were of ten several groups ranking the item 5 th or better. This underlines the need to design most information products on a group-by-group basis.

\section{Usefulness of Specific Information Products}

The same questions also provided information on how valuable a set of specifically proposed information products would be to the respondents (see Table S-2). The first seven 
Table S-1. COMPARATIVE USEPIJLNESS OP GRKERAL TYPES OP INFORMATION OH BIOMASS RNERGY

\begin{tabular}{|c|c|c|c|c|c|c|c|c|c|c|}
\hline $\begin{array}{l}\text { General Inf ormation } \\
\text { Types }\end{array}$ & $\begin{array}{c}\text { Total } \\
\text { Biomass } \\
\text { P \& C Re- } \\
\text { searchers }\end{array}$ & $\begin{array}{c}\text { Total } \\
\text { B.omass } \\
\text { Conv. Re- } \\
\text { searchers }\end{array}$ & $\begin{array}{c}\text { Eiomass } \\
\text { P \& C } \\
\text { Manufac- } \\
\text { Turer } \\
\text {. Reps }\end{array}$ & $\begin{array}{l}\text { Biomass } \\
\text { Conv. } \\
\text { Menufac- } \\
\text { zurer } \\
\text { Reps }\end{array}$ & $\begin{array}{l}\text { Biomass } \\
\text { State } \\
\text { Foresters }\end{array}$ & $\begin{array}{l}\text { Biomass } \\
\text { State } \\
\text { Foresters }\end{array}$ & $\begin{array}{l}\text { Bijmass } \\
\text { Forest } \\
\text { Frodusts } \\
\text { Engiาeers }\end{array}$ & $\begin{array}{c}\text { Biomass } \\
\text { Educa- } \\
\text { tors }\end{array}$ & $\begin{array}{c}\text { Biomass } \\
\text { CES } \\
\text { County } \\
\text { Agents }\end{array}$ & $\begin{array}{l}\text { Biomass } \\
\text { System } \\
\text { Managers }\end{array}$ \\
\hline & Ranking $^{\text {ii }}$ & Ranking & Eanking & Ranking & Ranking & Ranking & Rarking & Ranking & Ranking & Ranking \\
\hline State of the Art in Biomess & & & & & & & & & & \\
\hline Research & 3 & 2 & 3 & 2 & 1 & 4 & 8 & 2 & 13 & 7 \\
\hline $\begin{array}{l}\text { Biomass Researeh in Progress } \\
\text { Biomass Systems Installation/ }\end{array}$ & 2 & 4 & 6 & 10 & i & 14 & 11 & 3 & 8 & 7 \\
\hline $\begin{array}{l}\text { Operation Costs } \\
\text { Biomass System: Cost/ }\end{array}$ & 8 & 1 & 6 & 8 & 5 & 2 & 2 & 3 & 1 & 1 \\
\hline $\begin{array}{l}\text { Performance } \\
\text { Local Building Codes, }\end{array}$ & 6 & 2 & 8 & 5 & 8 & 1 & 1 & 6 & 3 & 3 \\
\hline Regulations & 19 & 20 & 10 & 6 & 8 & 19 & $: 0$ & 10 & 17 & 12 \\
\hline $\begin{array}{l}\text { Climatological Data } \\
\text { Marketing Statisties and }\end{array}$ & 10 & 16 & 14 & 17 & 13 & 7 & $\doteqdot 3$ & 1 & 3 & 19 \\
\hline $\begin{array}{l}\text { Sales Projections for } \\
\text { Biomass Systems } \\
\text { Biomass Systems Marketing }\end{array}$ & 19 & 16 & 14 & 12 & 14 & NA & $: 1$ & 19 & NA & 15 \\
\hline $\begin{array}{l}\text { Biomass Systems Marketing } \\
\text { ("How To Market") } \\
\text { Educational Institutions Offering }\end{array}$ & $N A^{b}$ & NA & 21 & 15 & NA & NA & $: 9$ & 20 & NA & NA \\
\hline $\begin{array}{l}\text { Biomass-Rela-ed Courses } \\
\text { Standards, Spec.fications, or }\end{array}$ & 15 & 19 & 14 & 20 & 14 & 10 & $=1$ & 12 & 8 & 15 \\
\hline $\begin{array}{l}\text { Certification for Biomass } \\
\text { Systems } \\
\text { Institutional, Social, Envi- }\end{array}$ & 18 & 13 & 13 & 3 & 14 & 17 & 4 & 14. & 12 . & 7 \\
\hline $\begin{array}{l}\text { ronmental, or Legal Aspects } \\
\text { of Biomass Applications } \\
\text { Expected Developments in }\end{array}$ & 6 & 10 & 18 & 15 & 5 & 15 & $\begin{array}{l}\boldsymbol{T} \\
\mathrm{H}\end{array}$ & 6 & 15 & 12 \\
\hline $\begin{array}{l}\text { Biomass ("Next } 10 \text { Years") } \\
\text { International Bi Jmass Energy }\end{array}$ & 4 & 7 & 3 & 10 & 3 & 3 & $: 3$ & 12 & 10 & 7 \\
\hline $\begin{array}{l}\text { Markets, Research, Programs, } \\
\text { Industry }\end{array}$ & 17 & 16 & 20 & 21 & 20 & 17 & $! 3$ & 21 & NA & NA \\
\hline Tax Credits, Grants, Incentives & 12 & 11 & 3 & i & 5 & 4 & 8 & 16 & 3 & l \\
\hline Coming Events in Biomass & 11 & 11 & 10 & 17 & 19 & 16 & 19 & 16 & 17 & 18 \\
\hline $\begin{array}{l}\text { Biomass Inf ormation Sources } \\
\text { Technical Expents on Biomass. }\end{array}$ & $i$ & 8 & 1 & 12 & 8 & 7 & 4 & 5 & 1 & $\mathbf{5}$ \\
\hline $\begin{array}{l}\text { Systems } \\
\text { Local Biomess Inf rastructure } \\
\text { Technical Descriptions of }\end{array}$ & $\begin{array}{r}4 \\
15\end{array}$ & $\begin{array}{r}4 \\
14\end{array}$ & $\begin{array}{l}14 \\
19\end{array}$ & $\begin{array}{r}12 \\
3\end{array}$ & $\begin{array}{l}3 \\
8\end{array}$ & $\begin{array}{r}7 \\
10\end{array}$ & $\begin{array}{l}13 \\
13\end{array}$ & $\begin{array}{l}10 \\
16\end{array}$ & $\begin{array}{r}15 \\
7\end{array}$ & $\begin{array}{r}7 \\
17\end{array}$ \\
\hline $\begin{array}{l}\text { Biomass Systems } \\
\text { Nontechnical Descriptions of }\end{array}$ & 8 & 4 & $\mathbf{1}$ & 7 & 12 & 4 & 2 & 6 & 10 & 4 \\
\hline $\begin{array}{l}\text { Biomass Systems } \\
\text { Biomass Systems Design }\end{array}$ & $\begin{array}{l}13 \\
14\end{array}$ & $\begin{array}{r}14 \\
9\end{array}$ & $\begin{array}{r}10 \\
9\end{array}$ & $\begin{array}{r}17 \\
9\end{array}$ & $\begin{array}{l}18 \\
17\end{array}$ & $\begin{array}{l}12 \\
13\end{array}$ & $\begin{array}{r}13 \\
6\end{array}$ & $\begin{array}{r}14 \\
9\end{array}$ & $\begin{array}{r}3 \\
14\end{array}$ & $\begin{array}{r}5 \\
14\end{array}$ \\
\hline Sample Size & 17 & 19 & 9 & 9 & 9 & 9 & 8 & 9 & 9 & 7 \\
\hline
\end{tabular}

The Ranking was based upon asxing respondents how useful each $\mathrm{i}$ :em would be to them (see text of main report). If ile:ms w.are tied, they were all given the highest possible rank.

b"NA" means the question was not asked of :his particular set of re.spondents.

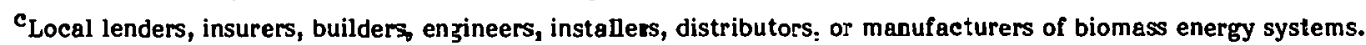

dThis item was derived by combiaing the results from four distinet juestions relatej to systems design (see Question 8a; items 4, 9, 10, and 11 in Appendix D). 
Table S-2. VALUB ASSESSMENT OF SPECIIC BIOMASS ENRRGY INPORMATION PRODDCTS

\begin{tabular}{|c|c|c|c|c|c|c|c|c|c|c|c|}
\hline \multirow[t]{2}{*}{$\begin{array}{l}\text { Specific Information } \\
\text { Produets }\end{array}$} & $\begin{array}{c}\text { Total } \\
\text { Biomass } \\
\text { P \& C Re- } \\
\text { searchers }\end{array}$ & $\begin{array}{c}\text { Total } \\
\text { Biomass } \\
\text { Conv. Fe- } \\
\text { searchers }\end{array}$ & $\begin{array}{c}\text { Biomass } \\
\text { P \& C } \\
\text { Manufac- } \\
\text { turer } \\
\text { Reps }\end{array}$ & $\begin{array}{c}\text { Biomass } \\
\text { Conv. } \\
\text { Manufac- } \\
\text { turer } \\
\text { Reps }\end{array}$ & $\begin{array}{l}\text { Biomass } \\
\text { State } \\
\text { Poresters }\end{array}$ & $\begin{array}{l}\text { Biomass } \\
\text { Private } \\
\text { Poresters }\end{array}$ & $\begin{array}{c}\text { Biomass } \\
\text { Forest } \\
\text { Products } \\
\text { Engineers }\end{array}$ & $\begin{array}{l}\text { Biomass } \\
\text { Educa- } \\
\text { tors }\end{array}$ & $\begin{array}{l}\text { Biomiss } \\
\text { CES } \\
\text { County } \\
\text { Agents }\end{array}$ & $\begin{array}{c}\text { Biomass } \\
\text { System } \\
\text { Man- } \\
\text { agers }\end{array}$ & $\begin{array}{c}\text { All } \\
\text { Biomass } \\
\text { Respon- } \\
\text { dents }^{5}\end{array}$ \\
\hline & Percent $^{\mathbf{B}}$ & Percent & Percent & Percent & Percent & Percent & Percent & Percent & Percent & Percent & Percent ${ }^{b}$ \\
\hline \multicolumn{12}{|l|}{$\begin{array}{l}\text { Bibliography of General } \\
\text { Readings on Biomass }\end{array}$} \\
\hline $\begin{array}{l}\text { Systems } \\
\text { Calendar of Biomass Con- }\end{array}$ & 47 & 26 & 33 & 25 & 56 & 11 & 38 & 78 & 44 & 14 & 38 \\
\hline ferences and Programs & 35 & 32 & 56 & 11 & 22 & 11 & 25 & 44 & 22 & 0 & 28 \\
\hline $\begin{array}{l}\text { or Schematics } \\
\text { Biomass System Design! }\end{array}$ & 47 & 53 & 73 & 56 & 44 & 67 & 63 & 78 & 56 & 43 & 57 \\
\hline $\begin{array}{l}\text { Biomass System Design } \\
\text { Computer Analytical Tools }\end{array}$ & 29 & 63 & 44 & 67 & 33 & 22 & 88 & 44 & 22 & 29 & 45 \\
\hline $\begin{array}{l}\text { (Models) for Biomass } \\
\text { System Design } \\
\text { Lists of Local Biomass }\end{array}$ & 35 & 32 & 33 & 33 & 0 & 22 & 38 & 44 & 0 & o & 26 \\
\hline $\begin{array}{l}\text { Experts } \\
\text { Lists of Biomass Technical }\end{array}$ & 35 & 26 & 22 & 56 & 56 & 33 & 38 & 44 & 67 & 29 & 39 \\
\hline $\begin{array}{l}\text { Experts } \\
\text { Technical Descriptions of }\end{array}$ & 71 & 58 & 44 & 44 & 89 & 33 & 38 & 56 & 22 & 57 & $x^{d}$ \\
\hline $\begin{array}{l}\text { Biomass Systems } \\
\text { Nontechnical Descriptions }\end{array}$ & 53 & 68 & 78 & 67 & 50 & 44 & 88 & 67 & 33 & 57 & $x^{d}$ \\
\hline $\begin{array}{l}\text { of Biomass Systems } \\
\text { List of Biomass Information }\end{array}$ & 35 & 16 & 44 & 11 & 38 & 33 & 38 & 33 & 67 & 43 & $x^{d}$ \\
\hline Sources & 82 & 58 & 78 & 44 & 67 & 33 & 75 & 67 & 67 & 43 & $x^{d}$ \\
\hline Sample Size & 17 & 19 & 9 & 9 & 9 & 9 & 8. & 9 & 9 & 7 & 105 \\
\hline
\end{tabular}

apercent is the percent:age of respondents rating the item as "essential" or "very useful" (as opposed to "somewhat useful" or "not at all useful").

b Although a percentage is given for All Biomass Respondents, it may not be indicative of the percentage of the whole biomass community interested in that item (since the proportion of each type of respondent in this study may not correspond to the proportion that group constitutes of the entire population).

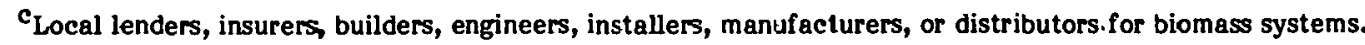

drX" indicates no overell percentage was calculated. For these items it may be necessary to develop different products/services for each group if their information needs are to be fully m.et. 
of these products could be targeted for large segments of the biomass energy community rather than for specific groups. Probably the most interesting results were:

- The relative lack of interest in calendars of events and in computer models for biomass system design;

- The much greater usefulness of manual analytical tools than of computer models for biomass system design;

- The high level of interest in biomass system diagrams or schematics, in design or installation handbooks or reference tables, in technical descriptions, and in information sources.

\section{Sources Used to Obtain Information}

Table S-3 lists the proportion of each group that had used different sources to obtain any type of solar information in the past few years. It wlll be noled thed a culumin is given for all biomass respondents; these summary figures are indicators (not estimates) of the familiarity of the entire biomass energy community with these information sources. In planning how specific information is to be transmitted, however, it will be essential to fully specify both the information products or services and the groups to be reached before making the decision of which information channels are to be used. One can not assume, for example, that the two or three top-rated sources should be used for all-or even most-of the information transmissions to the biomass energy community.

The information sources most familiar to the biomass groups studied were:

- Periodicals, newspapers, or magazines;

- Workshops, conferences, or training sessions;

- Government Printing Office (GPO);

- U.S. Department of Agriculture (USDA); and

- An organizational or local library.

\section{Technical Areas of Interest}

Table S-4 lists the proportion of each group interested in information on different biomass energy areas. The major results were:

- Highest levels of interest in commerical or industrial burning of biomass, and

- Minimal differences in levels of interest between areas for all biomass respon. dents as a whole.

\section{Advanced Information Acquisition Methods Used}

Table S-5 lists the proportion of each group that had used selected advanced acquisition methods to obtain information in the past year. The following results were observed:

- Biomass respondents in general were not very accustomed to using these techniques,

- Biomass Manufacturers, Private Foresters, and County Agents were the least likely of Biomass respondents to use these methods, and 
Table S-3. SOURCES USED TO OBTAIN SOLAR INPORMATION (Percent) ${ }^{\mathrm{a}}$

\begin{tabular}{|c|c|c|c|c|c|c|c|c|c|c|c|}
\hline Information Sources & $\begin{array}{l}\text { Total } \\
\text { Biomass } \\
\text { P \& C Re- } \\
\text { searchers }\end{array}$ & $\begin{array}{l}\text { Total } \\
\text { Biomass } \\
\text { Conv. Re- } \\
\text { searchers }\end{array}$ & $\begin{array}{l}\text { Biomass } \\
\text { P \& C } \\
\text { Manufac- } \\
\text { turer } \\
\text { Reps }\end{array}$ & $\begin{array}{l}\text { Biomass } \\
\text { Conv. } \\
\text { Manufac- } \\
\text { turer } \\
\text { Reps }\end{array}$ & $\begin{array}{c}\text { Biomass } \\
\text { Sta:e } \\
\text { Foresters }\end{array}$ & $\begin{array}{c}\text { Biomass } \\
\text { Private } \\
\text { Foresters }\end{array}$ & $\begin{array}{c}\text { Biomass } \\
\text { Forest } \\
\text { Products } \\
\text { Engineers }\end{array}$ & $\begin{array}{l}\text { Biomass } \\
\text { Educa- } \\
\text { tors }\end{array}$ & $\begin{array}{l}\text { Biomass } \\
\text { CES } \\
\text { County } \\
\text { Agents }\end{array}$ & $\begin{array}{l}\text { Biomass } \\
\text { System } \\
\text { Man- } \\
\text { agers }\end{array}$ & $\begin{array}{l}\text { All } \\
\text { Biommass } \\
\text { Respop- } \\
\text { dents }\end{array}$ \\
\hline $\begin{array}{l}\text { Public Media } \\
\text { Radio or TV } \\
\text { Periodicals, news- }\end{array}$ & $\mathrm{NA}^{\mathrm{C}}$ & $\mathrm{NA}$ & 78 & 22 & 89 & $\mathrm{NA}$ & 50 & 58 & 56 & 43 & $(57)^{d}$ \\
\hline $\begin{array}{l}\text { papers, or magazines } \\
\text { Private Solar-Involved Orgs. }\end{array}$ & NA &.$\quad$ NA & 100 & 78 & 100 & 100. & 100 & 89 & 89 & 100 & (94) \\
\hline $\begin{array}{l}\text { Private solar energy or } \\
\text { environmental orgs. } \\
\text { International Solar Energy }\end{array}$ & 65 & 53 & 11 & 67 & 56 & 33 & 38 & 89 & 44 & 71 & 53 \\
\hline $\begin{array}{l}\text { Society (ISES) (including } \\
\text { publications) } \\
\text { Solar Energy Industries Assn. } \\
\text { (SEIA) (including }\end{array}$ & 35 & 11 & 22 & 22 & o & 11 & 13 & 67 & 11 & 14 & 21 \\
\hline $\begin{array}{c}\text { publications) } \\
\text { Contacts With Professionals }\end{array}$ & 12 & 11 & 11 & 11 & o & 0 & 25 & 33 & o & 29 & 12 \\
\hline $\begin{array}{l}\text { Solar installer, builder, } \\
\text { designer, or manufacturer } \\
\text { Workshops, conferences, or }\end{array}$ & 53 & 42 & 33 & 56 & 67 & 22 & 75 & 100 & 56 & 86 & 56 \\
\hline $\begin{array}{l}\text { training sessions } \\
\text { Information Services }\end{array}$ & 71 & 74 & 56 & 44 & 78 & 44 & 50 & 89 & 67 & 86 & 67 \\
\hline $\begin{array}{l}\text { Respondent's organizational } \\
\text { library or local library } \\
\text { Commercial data base }\end{array}$ & $\begin{array}{l}88 \\
29\end{array}$ & $\begin{array}{l}83 \\
32\end{array}$ & $\begin{array}{l}56 \\
11\end{array}$ & $\begin{array}{l}56 \\
22\end{array}$ & $\begin{array}{l}78 \\
11\end{array}$ & $\begin{array}{l}22 \\
11\end{array}$ & $\begin{array}{l}25 \\
13\end{array}$ & $\begin{array}{l}89 \\
11\end{array}$ & $\begin{array}{l}33 \\
11\end{array}$ & $\begin{array}{l}29 \\
14\end{array}$ & $\begin{array}{l}62 \\
19\end{array}$ \\
\hline $\begin{array}{l}\text { Smittshonian Science Infor- } \\
\text { mation Exchange } \\
\text { Pederal library or infor- }\end{array}$ & 29 & 16 & NA & NA & 11 & NA & NA & 22 & NA, & 29 & (21) \\
\hline $\begin{array}{l}\text { mation center } \\
\text { Gov't. Printing Orfice (GPO) } \\
\text { National Technical Infor- }\end{array}$ & $\begin{array}{l}65 \\
59\end{array}$ & $\begin{array}{l}53 \\
74\end{array}$ & $\begin{array}{l}33 \\
67\end{array}$ & $\begin{array}{l}22 \\
44\end{array}$ & $\begin{array}{l}56 \\
78\end{array}$ & $\begin{array}{l}56 \\
22\end{array}$ & $\begin{array}{l}25 \\
75\end{array}$ & $\begin{array}{r}56 \\
100\end{array}$ & $\begin{array}{l}56 \\
78\end{array}$ & $\begin{array}{l}29 \\
43\end{array}$ & $\begin{array}{l}48 \\
65\end{array}$ \\
\hline $\begin{array}{l}\text { mation Service (NTIS) } \\
\text { Technical Information }\end{array}$ & 47 & 68 & 33 & 22 & 22 & 11 & 13 & 56 & 22 & 43 & 38 \\
\hline Center (TIC) & 41 & 16 & 22 & 11 & 22 & 0 & 25 & 56 & 22 & 29 & 25 \\
\hline $\begin{array}{l}\text { Govemment Solar-Involved Orgs. } \\
\text { Directly from the U.S. Depart- } \\
\text { ment of Energy } \\
\text { National Solar Heating \& }\end{array}$ & s. & 63 & 56 & $44^{\circ}$ & 100 & 22 & 50 & 67 & 78 & 43 & 59 \\
\hline $\begin{array}{l}\text { Cooling Information Center } \\
\text { Regional Solar Energy Centers } \\
\text { State energy or solar offices }\end{array}$ & $\begin{array}{l}18 \\
29 \\
41\end{array}$ & $\begin{array}{l}16 \\
16 \\
42\end{array}$ & $\begin{array}{l}22 \\
22 \\
22\end{array}$ & $\begin{array}{l}11 \\
22 \\
44\end{array}$ & $\begin{array}{r}0 \\
33 \\
78\end{array}$ & $\begin{array}{l}11 \\
11 \\
33\end{array}$ & $\begin{array}{l}38 \\
13 \\
50\end{array}$ & $\begin{array}{l}78 \\
44 \\
8 \mathrm{~s}\end{array}$ & $\begin{array}{l}56 \\
22 \\
78\end{array}$ & $\begin{array}{l}29 \\
14 \\
29\end{array}$ & $\begin{array}{l}26 \\
23 \\
50\end{array}$ \\
\hline $\begin{array}{l}\text { Other } \\
\text { Some other state or local gov't. } \\
\text { office or publicetion } \\
\text { Public utility company } \\
\text { U.S. Dept. of Agriculture, }\end{array}$ & 't. $\begin{array}{l}29 \\
53 .\end{array}$ & $\begin{array}{l}33 \\
53\end{array}$ & $\begin{array}{l}22 \\
56\end{array}$ & $\begin{array}{l}56 \\
22\end{array}$ & $\begin{array}{l}89 \\
56\end{array}$ & $\begin{array}{l}78 \\
33\end{array}$ & $\begin{array}{l}50 \\
50\end{array}$ & $\begin{array}{l}56 \\
7 \varepsilon\end{array}$ & $\begin{array}{l}67 \\
67\end{array}$ & $\begin{array}{l}29 \\
43\end{array}$ & $\begin{array}{l}48 \\
51\end{array}$ \\
\hline $\begin{array}{l}\text { including CES \& Forestry } \\
\text { Bio-Energy Council }\end{array}$ & $\begin{array}{l}76 \\
65\end{array}$ & $\begin{array}{l}58 \\
79\end{array}$ & $\begin{array}{l}44 \\
11\end{array}$ & $\begin{array}{l}44 \\
11\end{array}$ & $\begin{array}{l}89 \\
33\end{array}$ & $\begin{array}{l}78 \\
11\end{array}$ & $\begin{array}{l}38 \\
63\end{array}$ & $\begin{array}{l}89 \\
22\end{array}$ & $\begin{array}{r}100 \\
11\end{array}$ & $\begin{array}{l}14 \\
29\end{array}$ & $\begin{array}{l}65 \\
40\end{array}$ \\
\hline Sample Size & 17 & 19 & $\mathbf{g}$ & 9 & $\mathbf{9}$ & 9 & 8 & $\mathbf{g}$ & 9 & 7 & 105 \\
\hline
\end{tabular}

Percent is the percentage of respondents who used the source to obtain any solar information in the past few years.

Although a percentage is given for All Biomass Respondents, it may not be indicative of the percentage of the whole biomass community interested in that item (since the proportion of each type of respondent in this study may not correspond to the proportion that group constitutes of the entire sopulation).

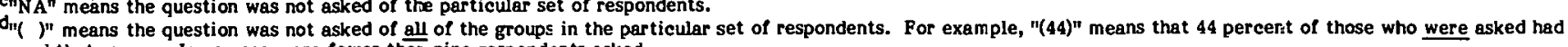
used that source. In no case were fewer than nine respondents asked. 
Table S-4. INTEREST IN INPORMATION ON BIOMASS BNRRGY TOPICS

\begin{tabular}{|c|c|c|c|c|c|c|c|c|c|c|}
\hline Topies & $\begin{array}{c}\text { Total } \\
\text { Biomass } \\
\text { P \& C Re- } \\
\text { searchers }\end{array}$ & $\begin{array}{c}\text { Total } \\
\text { Biomass } \\
\text { Conv. Re- } \\
\text { searchers }\end{array}$ & $\begin{array}{c}\text { Biomass } \\
\text { P \& C } \\
\text { Manufac- } \\
\text { turer } \\
\text { Reps }\end{array}$ & $\begin{array}{l}\text { Biomass } \\
\text { Conv. } \\
\text { Manufac- } \\
\text { turer } \\
\text { Reps }\end{array}$ & $\begin{array}{l}\text { Rinmass } \\
\text { State } \\
\text { Foresters }\end{array}$ & $\begin{array}{l}\text { Biomass } \\
\text { Private } \\
\text { Poresters }\end{array}$ & $\begin{array}{c}\text { Biomass } \\
\text { Forest } \\
\text { Products } \\
\text { Engineers }\end{array}$ & $\begin{array}{l}\text { Biomass } \\
\text { Educa- } \\
\text { tors }\end{array}$ & $\begin{array}{l}\text { Biomass } \\
\text { CES } \\
\text { County } \\
\text { Agents }\end{array}$ & $\begin{array}{l}\text { All } \\
\text { Biomass } \\
\text { Respon- } \\
\text { dents }\end{array}$ \\
\hline & Percent $^{a}$ & Percent & Percent & Percent & Percent & Percent & Percent & Percent & Percent & Percent $^{b}$ \\
\hline $\begin{array}{l}\text { Growth or Collection of } \\
\text { Biomass Materials }\end{array}$ & 88 & 47 & 56 & 67 & 89 & 67 & 63 & 78 & 44 & 66 \\
\hline $\begin{array}{l}\text { Liçuid I'uelo from Blemuw } \\
\text { Matusials }\end{array}$ & 63 & 84 & f7 & 33 & .78 & $2 ?$ & 63 & 78 & 89 & 64 \\
\hline $\begin{array}{l}\text { Gases Prom Biomass } \\
\text { Materials } \\
\text { Burnable Pellets, etc. from }\end{array}$ & b3 & 79 & is & 09 & 70 & 33 & 67 & 99 & 89 & 69 \\
\hline $\begin{array}{l}\text { Burnable Pellets, etc., from } \\
\text { Biomass }\end{array}$ & 53 & 53 & 67 & 88 & 89 & 78 & 75 & 56 & 44 & 64 \\
\hline $\begin{array}{l}\text { Residential Burning of } \\
\text { Wood }\end{array}$ & 47 & 37 & 44 & 67 & 89 & 33 & 50 & 100 & 67 & 56 \\
\hline $\begin{array}{l}\text { Commercial or Industrial } \\
\text { Burning of Biomass }\end{array}$ & 65 & 74 & 78 & 89 & 100 & 78 & 88 & 67 & 56 & 76 \\
\hline Sample Size & 17 & 19 & 9 & 9 & 9 & 9 & 8 & 9 & 9 & 98 \\
\hline
\end{tabular}

Percent is the percentage of respondents interested in the topic.

${ }^{b}$ Although a percentage is given for All Biomass Respondents, it may not be indicative of the percentage of the whole biomass community interested in that item (since the proportion of each type of respondent in this study may not correspond to the proportion that group constitutes of the entire population). The data for Biomass System Managers is not included in All Biomass Respondents, as they were not asked this question.

Table 95. ADVANCED INFORMATION $\Lambda$ CQUBBTHON MBTHODS USED

\begin{tabular}{|c|c|c|c|c|c|c|c|c|c|c|}
\hline $\begin{array}{l}\text { Aoquisition } \\
\text { Methods }\end{array}$ & $\begin{array}{c}\text { Total } \\
\text { Biomass } \\
\text { P \& C Re- } \\
\text { searchers }\end{array}$ & $\begin{array}{c}\text { Total } \\
\text { Biomass } \\
\text { Conv. Re- } \\
\text { searchers }\end{array}$ & $\begin{array}{c}\text { Biomass } \\
\text { P \& C } \\
\text { Manufac- } \\
\text { turer } \\
\text { Reps }\end{array}$ & $\begin{array}{c}\text { Biomass } \\
\text { Conv. } \\
\text { Manufar- } \\
\text {. turer } \\
\text { Reps }\end{array}$ & $\begin{array}{c}\text { Biomass } \\
\text { State. } \\
\text { Foresters }\end{array}$ & $\begin{array}{c}\text { Biomass } \\
\text { Private } \\
\text { Foresters }\end{array}$ & $\begin{array}{c}\text { Biomass } \\
\text { Forest } \\
\text { Products } \\
\text { Engineers }\end{array}$ & $\begin{array}{c}\text { Biomass } \\
\text { Educa- } \\
\text { tors }\end{array}$ & $\begin{array}{c}\text { Biomass } \\
\text { CES } \\
\text { County } \\
\text { Agents }\end{array}$ & $\begin{array}{c}\text { All } \\
\text { Biomass } \\
\text { Respon- } \\
\text { dents }\end{array}$ \\
\hline & Pcrecnt ${ }^{\theta}$ & Percent & Percent & Percent & Percent & Percent & Percent & Percent & Percent & Percent \\
\hline $\begin{array}{l}\text { Cunnutur Turminal Accoss } \\
\text { to Data Banks }\end{array}$ & 59 & 32 & 11 & 11 & 22 & 11 & 0 & 11 & 11 & 23 \\
\hline Sample Size & 17 & 19 & 9 & 9 & 9 & 9 & 8 & 9 & 9 & 98 \\
\hline
\end{tabular}

${ }^{a}$ Percent is the percentage of respondents who used the method in the past year.

b Although a percentage is given for All Biomass Respondents, it may not be indicative of the percentage of the whole biomass community interested in that item (since the proportion of each type of respondent in this study may not correspond to the proportion that group constitutes of the entire population). The data for Biomass System Managers are not included in All Biomass Respondents, as they were not asked this question. 
- Nonuse of computer terminals by Forest Products Engineers was unusual. The typical engineer interviewed in this study was more likely to have used computer terminals than microforms.

\section{Additional Findings}

- While none of the Biomass Conversion Researchers were working on projects related to P\&C, over half of the Biomass P\&C Researchers were working on conversion projects as well as P\&C projects. All of the P\&C Researchers held advanced degrees (beyond bachelors); only 58\% of the Conversion Researchers held advanced degrees. $\mathrm{P} \& \mathrm{C}$ Researchers tended to have degrees in chemical or biological fields, Conversion Researchers of ten had degrees in engineering. None of the Biomass Researchers were teaching, which was quite unusual among the researchers interviewed in this study.

- Compared to the other researchers included in this study, Total Biomass Researchers were significantly more interested in lists of biomass technical experts; lists of biomass information sources; and the institutional, social, environmental, and legal aspects of biomass energy systems.

- Conversion Researchers were more interested than P\&C Researchers in information on costs and systems design.

- Nonfederally Funded Conversion Researchers made considerably less use of the sources of available information than any of the other three groups of biomass researchers.

- Biomass P\&C Equipment Manufacturer Representatives had distinctly different information needs from Biomass Conversion Equipment Manufacturer Representatives. The representatives of $P \& C$ Manufacturers were much more conscious of their need for information, assigning the highest priority to lists of information sources; they were one of the few manufacturers groups in the entire study interested in this item. Compared to other manufacturer representatives they were also very interested in systems descriptions and systems design information.

- Neither Biomass P\&C Equipment Manufacturer Representatives nor Biomass Conversion Equipment Manufacturers Representatives made much use of the information sources listed, including the U.S. Department of Agriculture and the Bio-Energy. Council. It appears that the best way to get information to these groups may be directly, rather than through existing channels.

- State Forestry Office Representatives were familiar with a wide spectrum of information sources. In contrast, Biomass Private Foresters had used very few information sources.

- Private Foresters had obtained almost no solar information through DOE-funded or solar-related sources.

- Blomass CES County Agents were among the very few of the 86 groups studied who were interested in nontechnical system descriptions. 
Blank

$x v i$ 


\section{TABLE OF CONTENTS}

Management Summary $\ldots \ldots \ldots \ldots \ldots \ldots \ldots \ldots \ldots \ldots \ldots \ldots \ldots \ldots \ldots$

1.0 Introduction $\ldots \ldots \ldots \ldots \ldots \ldots \ldots \ldots \ldots \ldots \ldots \ldots \ldots \ldots \ldots \ldots \ldots \ldots \ldots \ldots$

1.1 Background................................... 1

1.2 Solar Energy Information Data Bank Program Planning ............ 2

1.3 Report Contents ................................ 3

2.0 Study Description $\ldots \ldots \ldots \ldots \ldots \ldots \ldots \ldots \ldots \ldots \ldots \ldots \ldots \ldots \ldots \ldots \ldots \ldots \ldots$

2.1 Study Characteristics $\ldots \ldots \ldots \ldots \ldots \ldots \ldots \ldots \ldots \ldots \ldots \ldots \ldots \ldots \ldots \ldots \ldots$

2.2 Groups Studied.................................. 5

2.2.1 Target Audiences, Classes, and Groups ................ 6

2.2.2 Criteria for Selection of Groups to Study $\ldots \ldots \ldots \ldots \ldots \ldots \ldots \ldots \ldots$

2.2.3. Groups Included in the Biomass Energy Study ............. 14

2.2.4 Biomass-Concerned Groups Included

in the General Solar Study ....................... 14

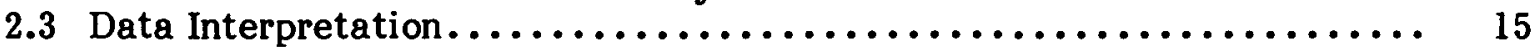

2.3.1 Impact of the Sample Frames: Who was Sampled? ........... 15

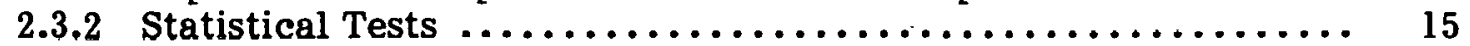

2.3.3 Hypotheses Versus Conclusions ..................... 16

2.3.4 Significance of Rankings ............................ 16

2.3.5 Alternative Measures of Usefulness ................... 16

2.3.6 Combining Results from Different Groups ................ 17

2.3.7 Specific Information Products...................... 17

2.3.8 Information Sources $\ldots \ldots \ldots \ldots \ldots \ldots \ldots \ldots \ldots \ldots \ldots \ldots \ldots \ldots \ldots \ldots \ldots$

3.0 Biomass Researchers $\ldots \ldots \ldots \ldots \ldots \ldots \ldots \ldots \ldots \ldots \ldots \ldots \ldots \ldots \ldots \ldots \ldots \ldots \ldots . \ldots 19$

3.1 Description of Respondents .......................... 19

3.1.1 Description of Sample ......................... 19

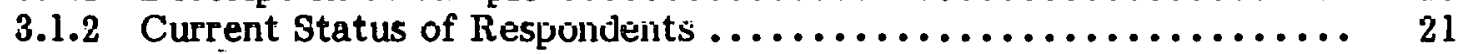

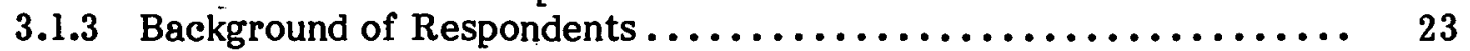

3.2 Information Needs of Respondents ....................... 24

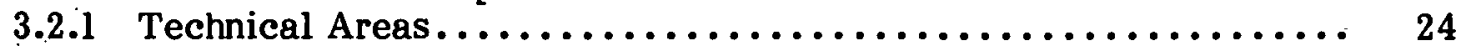

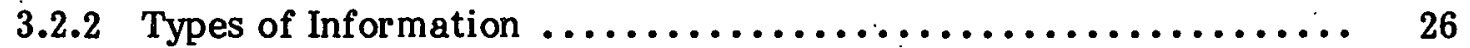

3.3 Acquisition of Information by Respondents................. 40

3.3.1. Use of Selected Information Sources .................. 40

3.3.2 Membership in Solar-Interested Organizations .............. 43.

3.3.3 Exposure to Publications on Solar Energy ................ 43

3.3.4 Use of Special Acquisition Methods .................... 43

3.4 Summary and Comments ........................... 47

4.0 Biomass Manufacturer Representatives...................... 49

4.1 Description of Respondents......................... 49

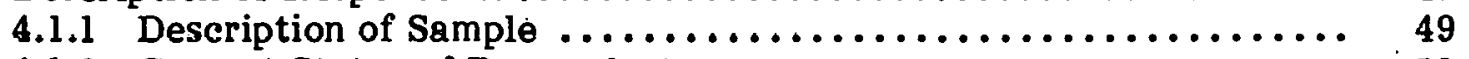

4.1 .2 Current Status of Respondents .................... 50

4.1.3 Background of Respondents ....................... 51 
TABLE OF CONTENTS (Continued)

Page

4.2 Information Needs of Respondents $\ldots \ldots \ldots \ldots \ldots \ldots \ldots \ldots \ldots \ldots \ldots \ldots \ldots \ldots$

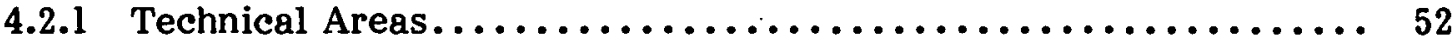

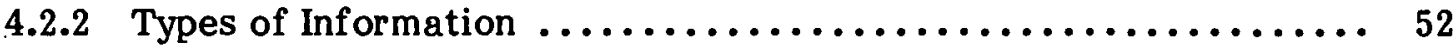

4.3 Acquisition of Information by Respondents.................. 58

4.3.1 Use of Selected Information Sources . . . . . . . . . . . . . 58

4.3.2 Membership in Solar-Interested Organizations .............. 62

4.3.3 Exposure to Publications on Solar Energy ................. 63

4.3.4 Use of Special Acquisition Methods .................. 64

4.4 Summary and Comments ........................... 64

5.0 Biomass State Forestry Office Representatives................. 67

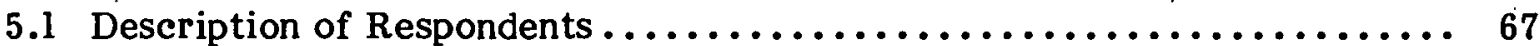

5.1 .1 Description of Sample ........................ 67

5.1 .2 Current Status of Respondents .................... 67

5.1 .3 Background of Respondents ........................ 69

5.2 Information Needs of Respondents ....................... 69

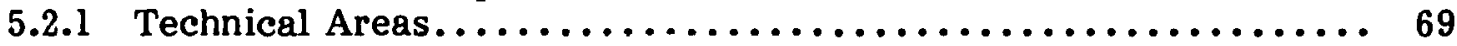

5.2 .2 Types of Information .......................... 69

5.3 Acquisition of Information by Respondents.................. 72

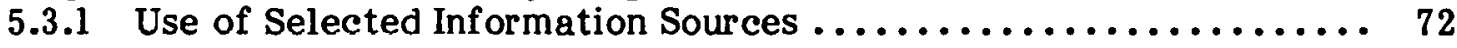

5.3.2 Membership in Solar-Interested Organizations .............. 74

5.3.3 Exposure to Publications on Solar Energy ................. 75

5.3 .4 Use of Special Acquisition Methods ................... 75

5.4 Summary and Comments $\ldots \ldots \ldots \ldots \ldots \ldots \ldots \ldots \ldots \ldots \ldots \ldots \ldots \ldots$

6.0 Biomass Private Foresters $\ldots \ldots \ldots \ldots \ldots \ldots \ldots \ldots \ldots \ldots \ldots \ldots \ldots \ldots \ldots \ldots \ldots$

6.1 Description of Respondents .......................... 79

6.1 .1 Description of Sample ............................ 79

6.1 .2 Current Status of Respondents ....................... 80

6.1 .3 Background of Respondents ....................... 80

6.2 Information Needs of Respondents $\ldots \ldots \ldots \ldots \ldots \ldots \ldots \ldots \ldots \ldots \ldots \ldots \ldots$.

6.2 .1 Technicul Aleas............................... 81

6.2 .2 Types of Information $\ldots \ldots \ldots \ldots \ldots \ldots \ldots \ldots \ldots \ldots \ldots \ldots \ldots \ldots . \ldots \ldots$

6.3 Acquisition of Information by Respondents................... 84

6.3 .1 Use of Selected Information Sources ................... 84

6.3.2 Membership in Solar-Interested Orgunizations .............. 86

6.3 .3 Exposure to Publications on Solar Energy $\ldots \ldots \ldots \ldots \ldots \ldots \ldots \ldots \ldots \ldots$

6.3.4 Use of Special Acquisition Methods ................... 87

6.4 Summary and Comments $\ldots \ldots \ldots \ldots \ldots \ldots \ldots \ldots \ldots \ldots \ldots \ldots \ldots \ldots \ldots$

7.0 Biomass Forest Products Engineers/Consultants $\ldots \ldots \ldots \ldots \ldots \ldots \ldots \ldots$

7.1 Description of Respondents ......................... 89

7.1 .1 Description of Sample $\ldots \ldots \ldots \ldots \ldots \ldots \ldots \ldots \ldots \ldots \ldots \ldots \ldots \ldots \ldots . \ldots \ldots$

7.1 .2 Current Status of Respondents $\ldots \ldots \ldots \ldots \ldots \ldots \ldots \ldots \ldots \ldots \ldots \ldots \ldots$

7.1 .3 Background of Respondents $\ldots \ldots \ldots \ldots \ldots \ldots \ldots \ldots \ldots \ldots \ldots \ldots \ldots \ldots . \ldots \ldots$ 
TABLE OP CONTENTS (Continued)

$\underline{\text { Page }}$

7.2 Information Needs of Respondents $\ldots \ldots \ldots \ldots \ldots \ldots \ldots \ldots \ldots \ldots \ldots \ldots \ldots . \ldots 1$

7.2.1 Technical Areas. ............................. 91

7.2.2 Types of Information $\ldots \ldots \ldots \ldots \ldots \ldots \ldots \ldots \ldots \ldots \ldots \ldots \ldots \ldots \ldots \ldots$

7.3 Acquisition of Information by Respondents ...................94

7.3.1 Use of Selected Information Sources .................. 94

7.3.2 Membership in Solar-Interested Organizations . . . . . . . . . . . 96

7.3.3 Exposure to Publications on Solar Energy .................. 97

7.3 .4 Use of Special Acquisition Methods ................... 97

7.4 Summary and Comments $\ldots \ldots \ldots \ldots \ldots \ldots \ldots \ldots \ldots \ldots \ldots \ldots \ldots \ldots \ldots \ldots$

8.0 Biomass Educators $\ldots \ldots \ldots \ldots \ldots \ldots \ldots \ldots \ldots \ldots \ldots \ldots \ldots \ldots \ldots \ldots \ldots \ldots \ldots \ldots . . \ldots 9$

8.1. Description of Respondents $\ldots \ldots \ldots \ldots \ldots \ldots \ldots \ldots \ldots \ldots \ldots \ldots \ldots \ldots . \ldots \ldots$

8.1.1 Description of Sample $\ldots \ldots \ldots \ldots \ldots \ldots \ldots \ldots \ldots \ldots \ldots \ldots \ldots \ldots \ldots$

8.1.2 Current Status of Respondents ........................ 100

8.1.3 Background of Respondents ............................ 101

8.2 Information Needs of Respondents $\ldots \ldots \ldots \ldots \ldots \ldots \ldots \ldots \ldots \ldots \ldots \ldots \ldots \ldots 10 \ldots$

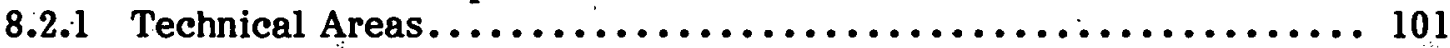

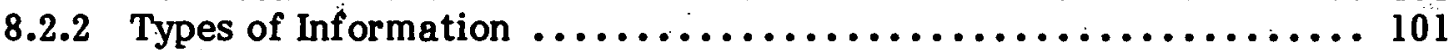

8.3 Acquisition of Information by Respondents.................. 105

8.3.1 Use of Selected Information Sources ................. 105

8.3.2 Membership in Solar-Interested Organizations .............. 108

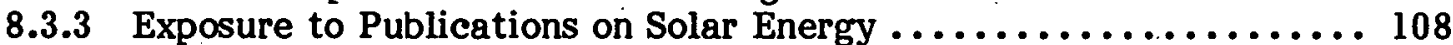

8.3.4 Use of Special Acquisition Methods ..................... 109

8.4 Summary and Comments ............................. 109

9.0 County Agents, Cooperative Extension Service $\ldots \ldots \ldots \ldots \ldots \ldots \ldots \ldots \ldots \ldots \ldots$. 111

9.1 Description of Respondents ...........................111

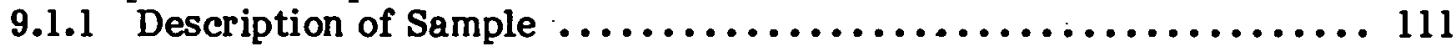

9.1.2 Current Status of Respondents ...................... 112

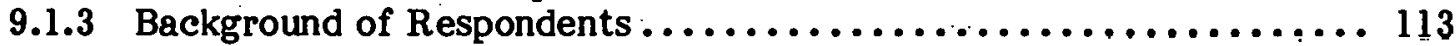

9.2 Iifurmation Needs of Respondents $\ldots \ldots \ldots \ldots \ldots \ldots \ldots \ldots \ldots \ldots \ldots \ldots \ldots$

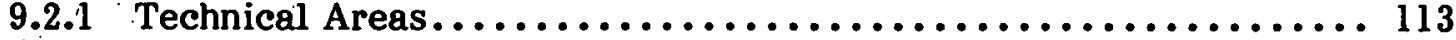

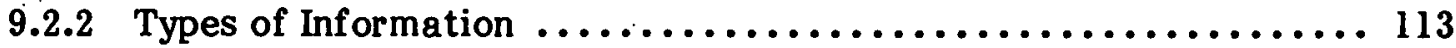

9.3 Acquisition of Information by Respondents $\ldots \ldots \ldots \ldots \ldots \ldots \ldots \ldots \ldots \ldots 118$

9.3.1 Use of Selected Information Sources ................... 118

9.3.2 Membership in Solar-Interested Organizations ............. 122

9.3.3 Exposure to Publications on Solar Energy ................ 122

9.3.4 Úse of Special Acquisition Methods ................... 122

9.4 Summary and Comm ents $\ldots \ldots \ldots \ldots \ldots \ldots \ldots \ldots \ldots \ldots \ldots \ldots \ldots \ldots \ldots \ldots \ldots, 123$

10.0 Biomass System Managers $\ldots \ldots \ldots \ldots \ldots \ldots \ldots \ldots \ldots \ldots \ldots \ldots \ldots \ldots \ldots \ldots \ldots \ldots \ldots$

10.1 Description of Respondents ......................... 125

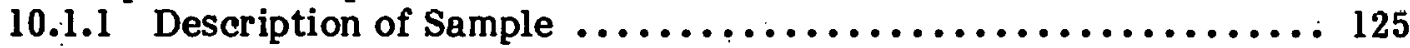

10.1.2 Current Status of Respondents ................... 126

10.1.3 Background of Respondents ..................... 126 


\section{TABLE OF CONTENTS (Concluded)}

Page

10.2 Information Needs of Respondents ....................... 127

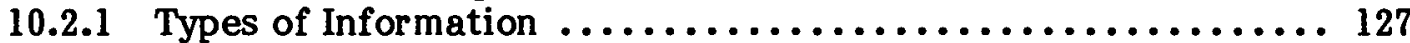

10.3 Acquisition of Information by Respondents $\ldots \ldots \ldots \ldots \ldots \ldots \ldots \ldots \ldots \ldots$

10.3.1 Initial Information Sources ....................... 130

10.3.2 Use of Selected Information Sources ................ 130

10.3.3 Membership in Solar-Interested Organizations ............. 133

10.3.4 Exposure to Publications on Solar Energy ................ 134

10.4 Summary and Comments ............................ 134

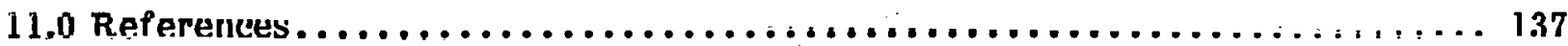

Appendix A: Groups Included in Study $\ldots \ldots \ldots \ldots \ldots \ldots \ldots \ldots \ldots \ldots \ldots \ldots \ldots \ldots$

Appendix B: $\quad$ Study Development and Procedure $\ldots \ldots \ldots \ldots \ldots \ldots \ldots \ldots \ldots \ldots \ldots$

Appendix C: Letter of Introduction $\ldots \ldots \ldots \ldots \ldots \ldots \ldots \ldots \ldots \ldots \ldots \ldots \ldots \ldots \ldots \ldots$

Appendix D: Study Questionnaire $\ldots \ldots \ldots \ldots \ldots \ldots \ldots \ldots \ldots \ldots \ldots \ldots \ldots \ldots \ldots$

Appendix E: $\quad$ Statistical Testing $\ldots \ldots \ldots \ldots \ldots \ldots \ldots \ldots \ldots \ldots \ldots \ldots \ldots \ldots \ldots \ldots \ldots \ldots 189$

Appendix F: $\quad$ Biomass Data Tables............................. 193 


\section{LST OP FIGURES}

$\underline{\text { Page }}$

3-1 Usefulness of Selected Inf ormation Items: Federally

Funded Biomass Production and Collection Researchers

3-2 Usefulness of Selected Information Items: Nonfederally

Funded Biomass Production and Collection Researchers

3-3 Usefulness of Selected Information Items: Federally

Funded Biomass Conversion Researchers

3-4 Usefulness of Selected Information Items: Nonfederally

Funded Biomass Conversion Researchers

3-5 Usefulness of Selected Inf ormation Items: Total Federally

Funded Biomass Researchers

3-6 Usefulness of Selected Information Items: Total Nonfederally

Funded Biomass Researchers

3-7 Usefulness of Selected Information Items: Total Biomass

Production and Collection Researchers .......................

3-8 Usefulness of Selected Information Items: Total Biomass

Conversion Researchers..................................

3-9 Usefulness of Selected Information Items: Total Biomass

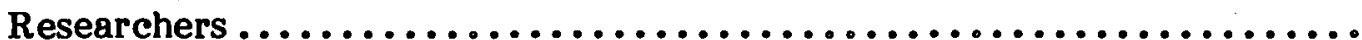

3-10 Usefulness of Selected Information Items: All Researchers ........... 37

4-1 Usefulness of Selected Information Items: Biomass Production and Collection Equipment Manufacturer Representatives

4-2 Usefulness of Selected Information Items: Biomass

Conversion Equipment Manufacturer Representatives

4-3 Usefulness of Selected Information Items: All Manufacturer

Representatives

4-4 Use of Selected Information Sources: Biomass Production and Collection Equipment Manufacturer Representatives.

4-5 Use of Selected Information Sources: Biomass Conversion

Equipment Manufacturer Representatives ......................

4-6 Use of Selected Information Sources: All Manufacturer

Representatives 
LIST OF FIGURES (Continued)

Page

5-1 Usefulness of Selected Information Items: Biomass State

Forestry Office Representatives $\ldots \ldots \ldots \ldots \ldots \ldots \ldots \ldots \ldots \ldots \ldots \ldots, 71$

5-2 Use of Selected Information Sources: Biomass State

Forestry Office Representatives $\ldots \ldots \ldots \ldots \ldots \ldots \ldots \ldots \ldots \ldots \ldots \ldots \ldots, 73$

6-1 Usefulness of Selected Inf ormation Items: Biomass Private

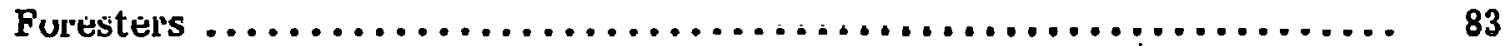

6-2 Use of Selected Information Sources: Biomass Private Foresters ........ 85

7-1 Usefulness of Selected Information Items: Biomass Forest

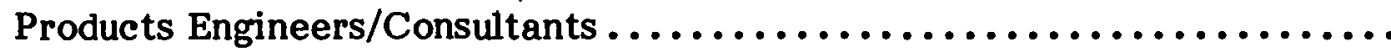

7-2 Use of Selected Information Sources: Biomass Forest

Products Engineers/Consultants ............................ 95

8-1 Usefulness of Selected Information Items: Biomass Educators ......... 103

8-2 Usefulness of Selected Information Items: All Educators $\ldots \ldots \ldots \ldots \ldots \ldots 104$

8-3 Use of Selected Information Sources: Biomass Educators ............ 106

8-4 Use of Selected Information Sources: All Educators $\ldots \ldots \ldots \ldots \ldots \ldots \ldots \quad 107$

9-1 Usefulness of Selected Information Items: Biomass

CES County Agents $. \ldots \ldots \ldots \ldots \ldots \ldots \ldots \ldots \ldots \ldots \ldots \ldots \ldots \ldots \ldots, 115$

9-2 Usefulness of Selected Information Items: All CES County Agents....... 116

9-3 Usefulness of Selected Information Items: All CES State

Specialists $\ldots \ldots \ldots \ldots \ldots \ldots \ldots \ldots \ldots \ldots \ldots \ldots \ldots \ldots \ldots \ldots, 117$

9-4 Use of Selected Information Sources: Biomass CES County Agents... . . . . 119

9-5 Use of Selected Information Sources: All CES County Agents .......... 120

9-6 Use of Selected Information Sources: All CES State Speclallsts $\ldots \ldots \ldots \ldots .121$

10-1 Usefulness of Selected Information Items: Biomass System

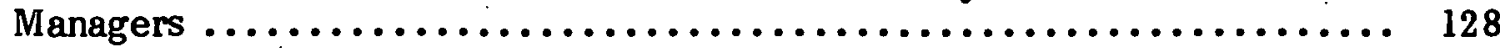

10-2 Usefulness of Selected Information Items: Active Solar

Heating and Cooling (SHAC) Building Owners/Managers ............. 129 


\section{LST OF FIGURES (Concluded)}

Page

10-3 Use of Selected Information Sources: Biomass System Managers........ 131

10-4 Use of Selected Information Sources: Active Solar

Heating and Cooling (SHAC) Building Owners/Managers ............ 132

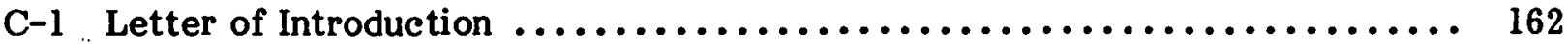

D-1 Questionnaire................................... 166

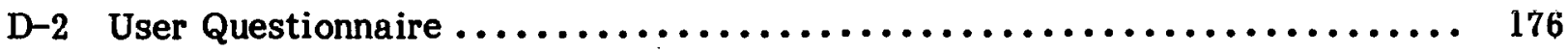

F-1 Biomass Data Tables................................ 199 
Blank

xxiv 


\section{LST OF TABLES}

$\underline{\text { Page }}$

S-1 Comparative Usefulness of General Types of Information on

Biomass Energy $\ldots \ldots \ldots \ldots \ldots \ldots \ldots \ldots \ldots \ldots \ldots \ldots \ldots \ldots \ldots \ldots \ldots \ldots$

S-2 Value Assessment of Specific Biomass Energy Information

Products ....................................... xi

S-3 Sources Used to Obtain Solar Information. ................... xiii

S-4 Interest in Information on Biomass Energy Topies ............... xiv

S-5 Advanced Information Acquisition Methods Used $\ldots \ldots \ldots \ldots \ldots \ldots \ldots \ldots \ldots$

2-1 Biomass Energy System Information Users $\ldots \ldots \ldots \ldots \ldots \ldots \ldots \ldots \ldots \ldots \ldots \ldots$

3-1 Completion of Interviews: Biomass Researchers................. 20

3-2 Levels of Involvement: ,Biomass Researchers $\ldots \ldots \ldots \ldots \ldots \ldots \ldots \ldots \ldots \ldots \ldots$

3-3 Levels of Informedness: Biomass Researchers................... 23

3-4 Areas of Interest: Biomass Researchers ..................... 25

3-5 Summary: Ranks of Top-Rated Information Items: Biomass

Researchers and All Researchers ......................... 38

3-6 Sources Used to Obtain Solar Information: Biomass Researchers........ 41

3-7 MembershipinSolar-InterestedOrganizations:Biomass Researchers 44

3-8 Publications Read Which Included Information on Solar Energy:

Biomass Researchers ............................... 45

3-9 Use of Special Acquisition Methods: Biomass Researchers . . . . . . . . . 47

4-1 Completion of Interviews: Biomass Manufacturer

Representatives ................................. 50

4-2 Areas of Interest: Biomass Manufacturer Representatives . . . . . . . . . 52

5-1 Completion of Interviews: Biomass State Forestry Office

Representatives ................................. 68

5-2 Areas of Interest: Biomass State Forestry Office Representatives, Biomass. Private Foresters, and Biomass Forest Products

Engineers/Consultants ............................. 70

6-1 Completion of Interviews: Biomass Private Foresters $\ldots \ldots \ldots \ldots \ldots \ldots \ldots$ 


\section{LST OF TABLES (Concluded)}

Page

6-2 Areas of Interest: Biomass Private Foresters, Biomass State Forestry Office Representatives, and Biomass Forest

Products Engineers/Consultants ......................... 81

7-1 Completion of Interviews: Biomass Forest Products

Engineers/Consultants .............................. 90

7-2 Areas of Interest: Biomass Forest Products Engineers/Consultants, Biomass State Forestry Office Representatives, and Biomass

Privet.e Forest.ers

8-1 Completion of Interviews: Biomass Educators................. 100

9-1 Completion of Interviews: Biomass County Agents $\ldots \ldots \ldots \ldots \ldots \ldots \ldots \ldots \ldots 12$

10-1 Completion of Interviews: Biomass System Managers . . . . . . . . . . 126

A-1 Groups Studied.................................... 141

B-1 Cooperative Extension Service (CES): States Represented in

Samples ......................................... 155

D-1 Selected Urganizations About Which Biomass Respondents

Were Asked

F-1 Groups and Combination Groups with Data Included in

Appendix F....................................... 195

F-2 Combination Groups $\ldots \ldots \ldots \ldots \ldots \ldots \ldots \ldots \ldots \ldots \ldots \ldots \ldots \ldots \ldots \ldots \ldots$

F-3 List of Biomass Data Tables $\ldots \ldots \ldots \ldots \ldots \ldots \ldots \ldots \ldots \ldots \ldots \ldots \ldots \ldots$ 


\section{SECTION 1.0}

\section{INTRODUCTION}

This report describes the results of a series of telephone interviews with potential users of information on biomass energy technologies. These interviews, part of a larger study covering nine different solar technologies, attempted to identify:

- the type of information each distinctive group of information users needed, and

- the best way of getting information to that group.

This section explains the background of the study, places this report in the context of the overall program, and describes the structure of this report.

\subsection{BACKGROUND}

The rapid, widespread commercialization of solar energy will be necessary if the United States is to meet the energy crises of the next $\mathbf{5 0}$ years. But the use of solar energy will never reach meaningful levels without both the recognition that information transfer is essential to commercialization and the deliberate development of systems for the transfer of information. For example: scientists need the latest solar research results to enhance their own efforts; engineers and installers need performance data to design solar systems; public interest groups need environmental impact data to support solar technologies against conventional energy alternatives; potential owners of solar energy systems need cost information to make purchase decisions; the general public needs basic information to weigh which public policies to support.

In 1974 the Congress, noting the importance of information transfer and recognizing the value to the solar community of an integrated, comprehensive data collection and information dissemination system, called for the implementation of a Solar Energy Information Data Bank (SEIDB). In The Solar Energy Research and Development Act (P.L. 93473) Congress stated that the SEIDB should be established "for the purpose of collecting, reviewing, processing, and disseminating information and data ... in all of the solar energy technologies."

The U.S. Department of Energy (DOE) has assigned the Solar Energy Research Institute (SERI) the task of serving as the lead center to fulfill this Congressional mandate to collect all types of solar-related information, to convert it into a user-oriented format, and to disseminate this information to the widest possible range of persons and groups with an interest in solar energy. These groups range from decision makers at all levels of government to manufacturers of solar products; from solar architects, installers, and service persons to home or farm owners; and from banks and financial institutions to scientists and researchers. In accord, SERIs Information Systems Division (ISD) is now in the process of collecting solar information, building data bases, and preparing and disseminating information through a variety of products and services.

The long-range objective of the SEIDB is a centrally coordinated network to ensure that all individuals concerned with solar energy have prompt and efficient access to whatever information is necessary to support sound decisions. Ultimately this information will be accessible through a variety of means (publications, computer data systems, audiovisual 
products, the Solar Energy Information Center, inquiry and referral services, etc.) to serve the diverse requirements of the solar community.

\subsection{SOLAR ENERGY INPORMATION DATA BANK PROGRAM PLANNING}

In the past decade, information scientists have studied many organizations responsible for data collection and information product development. A consistent finding of this research is that a key to the successful, efficient operation of such an organization is to design the entire system with the potential information user in mind. It is essential that development of information products and data bases be targeted for specific users rather than merely developed spontaneously. The information users, their information needs, and the priority of those needs must all be identified before effective information products and services can be developed efficiently. To ensure that the SEIDB is responsive to the high-priority information needs of the solar community, the Information Market Research Section of ISU is performing the following tasks:

1. Defining the community of solar information users,

2. Setting priorities as to which groups of information users have the most important near-term information needs,

3. Determining the near-term information needs of the high-priority users,

4. Determining the information channels which can be effectively used to reach the high-priority users,

5. Determining what high-priority information needs are being met fully by existing products and services, and

6. Recommending additional, targeted, cost-effective information products and services to meet high-priority needs.

The results of the first two tasks are described in a previous document [1]. First, for each solar technology, those members or potential members of the solar community who will need solar information were identified; second, the relative importance of meeting the near-term information needs of each group of information users was described. This document provides guidelines to SEIDB planners as to who might be using the SEIDB and whose near-term needs are the most important.

The results of the third and fourth tasks are described in the current set of ten reports (see Section 1.3). These reports document the high-priority information needs and the most familiar information channels for each of 86 groups which were interviewed by telephone.

There have been a few previous studies which asked homeowners what solar information they needed, but this is the only known study to provide data on the solar information that such groups as researchers, manufacturers, architects, engineers, installers, lawyers, bankers, insurers, public interest groups, state energy offices, and agricultural extension agents themselves say they want.

The data from this study will be used along with other data to determine what new information products and services SERI, the SEIDB Network, and the entire solar information outreach community should be preparing for and disseminating to the solar community. These data will include (but not be limited to): contacts with SERI 
specialists; review of the Annual Operating Plans, Institutional Plans, and Program Plans of DOE and SERI; reviews of other solar literature; development of an "information user profile" data base from mailing list response cards; information user panels; direct contacts with members of the solar community at conferences, training sessions, etc.; visits to headquarters of national associations of users; and feedback provided by users of existing information products. Since information needs and priorities will continuously change, these tasks will necessarily be ongoing.

\subsection{REPORT CONTENTS}

This biomass report is one of ten issued on the results of these studies of solar energy information users. The full set of reports covers:

- Photovoltaics

- Passive Solar Heating and Cooling

- Active Solar Heating and Cooling

- Biomass Energy

- Solar Thermal Electric Power

- Industrial and Agricultural Process Heat

- Wind Energy

- Ocean Energy

- Solar Energy Storage

- General Solar Energy

Section 2.0 of this report describes the type of study conducted and the resulting constraints. The method used to select these groups is also described in Section 2.0. Several groups discussed in another report from this study also indicated an interest in information on biomass energy. These groups are listed in Section 2.2.4. Sections 3.0 through 9.0 describe the results of studies of:

- Federally Funded Researchers involved in the Production and Collection (P\&C) of biomass energy feedstock,

- Nonfederally Funded Biomass P\&C Researchers,

- Federally Funded Researchers involved in the Conversion of biomass feedstock to energy,

- Nonfederally Funded Biomass Conversion Researchers,

- Representatives of Manufacturers of agricultural or forest Biomass Production and Collection Equipment,

- Representatives of Manufacturers of Biomass Conversion Equipment,

- Representatives of State Forestry Offices,

- Private Foresters who have been involved with biomass energy,

- Forest Products Engineers and Consultants interested in biomass energy,

- Educators teaching college-level courses in biomass energy, 
- Cooperative Extension Service County Agents who will be needing information on biomass energy, and

- Biomass Energy System Managers.

These respondents were asked specifically about their needs for information on biomass energy systems. In each of these sections describing study results, a standard presentation format has been used.

The appendices contain a list of all 86 groups interviewed (including the technologies other than biomass energy). They also contain a description of how the study was developed, a copy of the letter of introduction, sample questionnaires, a description of the statistical tests used, and the data from the studies of the biomass groups. 


\section{SECTION 2.0}

\section{STUDY DESCRIPTION}

This section gives a brief description of the study. Appendix B gives additional information on how the study was designed and conducted. This section also explains how groups from the biomass energy community were selected as those to be sampled and gives a few comments on interpretation of study results. The study findings are reported in Sections 3.0 through 9.0.

\subsection{STUDY CHARACTERISTICS}

Between 3 September 1979 and 13 October 1979 Market Opinion Research, Inc. (MOR) of Detroit, Michigan-under subcontract to the Solar Energy Research Institute (SERI)-conducted telephone interviews with 86 distinct groups of solar information users. Approximately nine respondents were interviewed from each group. Interviews were based upon professionally reviewed and tested questionnaires (see Appendix D); they took an average of 18 minutes to complete. The 86 groups, selected to cover 9 solar technologies/applications, are listed in Appendix A. The results discussed in this report are from the 12 of those 86 studies which dealt specifically with biomass energy.

Studies of 86 groups, each interested either in one of nine solar specific technologies or in solar technologies in general, provided an extremely broad view of the information needs of the solar community. Although the sample size of nine respondents per group was small, the data still proved to be adequate for planning purposes. It was possible to determine which information was the most important to the respondents and what was the best channel for disseminating that information. A variety of valid statistical tests were performed, both to compare the priorities a group gave to different information items and to compare the priorities different groups gave to the same item.

The respondents proved to be very cooperative. Considering the length and nature of the telephone interviews, it was surprising that only about $3 \%$ of the respondents terminated an interview or refused to be interviewed. This finding supported the interviewers' statements that the respondents were very interested in telling what they were doing in the field of solar energy, in obtaining solar information, and in specifying what solar information would prove the most valuable. It was also observed that the number of respondents answering "don't know" or not answering a question was quite low. Including those cases where the potential respondent could not be reached within three attempts (or before the required number of interviews was completed), where the respondent refused to be interviewed, where the respondent terminated the interview prematurely, etc., the completion rate for the entire study was about $75 \%$. The completion rate for each individual group is given in the section in which that group is discussed.

\subsection{GROUPS STUDIED}

One of the most important tasks was the selection of the groups of potential users of solar information to be studied. Before this could be done, however, it was necessary to list the important groups constituting the biomass energy community and to develop a conceptual framework within which selections could be made. 


\subsubsection{Target Audiences, Classes, and Groups}

An important information science concept in developing information products and services is that of the "target audience" or "target group." These are generally defined as a collection of individuals or organizations who have similar information needs and information-acquiring habits. People in the same group tend to need information on the same subjects, at a similar technical level, and within a similar timeframe. In developing an information product program, it is important to begin with a typology that assigns information users who have similar needs to common groupings. This allows development of efficient, targeted information products to meet identified needs of specific users, without inundating other members of the solar community with unneeded information.

In Solar Information User Priority Study [1] such a typology was developed. Under this system members of the solar community were placed in distinet "user groups." A set of user groups formed a "user class" and a collection of user classes formed a "target audience." For more precise definitions:

- A User Group is the most basic category of information users who can be combined together under a single definitive title (e.g., Civil Engineers). A single information user group should be addressable by many specific information products. The purpose of defining distinct information User Groups is to identify a single set of users who can be served by the same information product (e.g., a civil engineers' handbook).

- A User Class is a set of information user groups which exhibit many common distinguishing characteristics (e.g., Facility or System Designers). A single information user class should be addressable by many general information products. The purpose of defining separate information User Classes is to identify sets of two or more groups of users who can be served by similiar information products (e.g., solar heating and cooling system design models).

- A Target Audience is a set of information user classes which exhibit some common distinguishing characteristics (e.g., Researchers). A single Target Audience should be addressable by one or more distinct types of information products. The purpose of defining separate information user Target Audiences is to identify broad sets of users who can be served by the same generic types of information products (e.g., research-in-progress newsletters).

Following this system, all solar information users fall within one or more of five Target Audiences. These Target Audiences are:

Researchers - those who are actively involved in researching, developing, and testing of new state-of-the-art technical developments in solar energy.

Applications Technologists - those involved in translating research results into marketable equipment and services. This classification includes manufacture, distribution, sales, design, installation, and maintenance of solar systems or components.

Facilitators - those whose decisions or actions directly aid (in either a positive or negative manner) the commercialization of solar energy. Thus, congressmen would be Facilitators in that they have the ability to pass legislation giving incentives; lobbyists in that they can affect legislation; state energy offices in that they can initiate demonstration projects; and The Environmental Protection Agency (EPA) in that it can forbid construction of a manufacturing plant at a specific site. 
Users or Prospective Users - those individuals or organizations who have already applied this type of solar energy technology in their operations or have a reasonable chance of doing so in the near future.

General Public - Individuals who are not likely to utilize solar energy in the near future. An important aspect of this audience is its ability to influence the course of solar energy technologies through political influence, pro or con.

Based upon this scheme, the biomass energy information-user community has been defined. Table 2-1 enumerates the user groups comprising the biomass energy information community and shows into which target audience each falls [1].

\subsubsection{Criteria for Selection of Groups to Study}

From Table 2-1, it is rapidly evident that there are many user groups who will eventually be needing information on biomass energy. The problem was, thus, to select those groups to be included as a part of this study. To determine which groups would be studied, each group was evaluated with respect to the following selection criteria:

- appropriateness of using a structured telephone interview to collect information from the group on information needs and habits,

- relative priority of the group's short- or medium-range information needs, and

- availability of a sample frame for the group.

First, for many groups a structured telephone interview was not an appropriate method for defining information needs. It was not practical to interview the U.S. Department of Energy (DOE) or an organization like the Electric Power Research Institute, nor to survey a group like Congressional committee staff which would be too busy to respond. Rather than defining the information needs of these groups by telephone interviews, they will be contacted directly in FY 1981.

Second, only those groups with a high immediate or potential need for biomass energy information were selected. Further, since fulfilling short-range information needs is critical, it was decided that in most cases those people who were already involved with biomass energy would be sampled. It was felt that these were the people who would be primary users of the SEIDB over the next few years. These groups had been identified earlier in the Solar Information User Priority Study [1].

Finally, for many of the groups, lists of persons to be interviewed could not be developed or acquired. In the absence of sample frames, studies of such groups were not possible. (For more detail on sample frame development, see Appendix B.) 
Table 2-1. BIOMASS ENERGY SYSTEMS NFORMATION USERS

Target Audiences

User Classes

User Groups

$1.0 \quad$ Researcheis

1.1 DOE-Funded Researchers or Developers

Contractors

National Laboratories

1.2 Non-DOE, Federally Funded Researchers or Developers

National science Foundation (NSF)

U.S. Department of Agriculture (USUA)

Environmental Protection Agency (EPA)

National Aeronautics and Space Administration. (NASA)

1.3 Nonfederally Funded Researchers or Developers

Universities

Biomass Equipment Manufacturers or Potential

Manufacturers

Trade Research Associations

Electric Power Research Institute (EPRI)

Gas Research Institute

Independent Research Organizations

Industrial Solar Users

\subsection{Applications Technologists}

2.1 Biomass-Related Manufacturers

Boiler Manufacturers

Woodstove and Prefabricated Fireplace Manufacturers

Incinerator Manufacturers

Biomass Conversion Equipment Manufacturers

Dewatering Equipment Manufacturers

Fermentation and Distillation Equipment Manufacturers

Anaerobic Digestor Manufacturers

Agricultural or Forestry Equipment Manufacturers

Auto Manufacturers

2.2 Biomass Facility or System Designers

System Designers/Engineers

Architectural/Engineering Design Firms

Mechanical Engineers

Chemical Engineers

Biochemical Engineers

Sanitary Engineers 
Table 2-1. BIOMASS ENERGY SYSTEMS INFORMATION USERS (Continued)

2.3 Builders, Developers, or Contractors

Homebuilders

General Contractors

Architectural/Engineering Construction Firms

Mechanical Engineering Contractors

Construction Engineers

2.4 Biomass Systems Installers or Maintainers

Woodstove Installers

Chimneysweeps

Stonemasons

Pipefitters

Carpenters

Plumbers

Sheet Metal Workers

Maintenance Workers

Construction Workers

2.5 Biomass Equipment or Product Distributors

2.6 Technical Specialists for Utility, Government, Commercial, or Industrial Organization Using a

Biomass System

Operation Managers

Plant Engineers

Planners

2.7 Producers or Collectors of Biomass Feedstock

Owners of Farms

Owners of Private Forests

Owners of Livestock Feedlots

Wood Products Industry

Pulp and Paper Industry

Food Processing Industry

Agricultural Engineers

Foresters

Forest Managers

Silviculture Experts

Aquaculture Experts

2.8 Convertors or Vendors of Biomass Fuels or

By-products

Gasoline Stations

Municipal Waste and Refuse Departments

Petrochemical Industry

Alcohol Production Industry

Producers of Gaseous Fuels

Chemical Industry

Ammonia Producing Industry

Animal Feed Próducers 
Table 2-1. BIOMASS ENERGY SYSTEMS INFORMATION USERS (Continued)

Biochemists

Agricultural Engineers

3.0 Facilitators

3.1 Legislators or Staff

Congressmen

Congressional Committee Staff

State Legislators

National Conference of State Legislatures

3.2 Local Government Organizations

rounty Government. Officials

Local Government Officials

Municipal Planners

Municipal Waste or Sewage Departments

Tax Assessors and Officials

3.3 Government Solar-Active Organizations

DOE-Conservation and Solar Energy (C\&SE)

DOE-Energy Information Administration (EIA)

DOE-Energy Research (ER)

DOE-Regional Solar Energy Centers (RSECs)

DOE-Regional Energy Offices

DOE-Energy Extension Service

National Center for Appropriate 'Technology (NCAT)

Ū.S. Department of Agriculture (USDA)-Cooperative Extension Service (CES)

USDA-Forest Products Lab

USDA-Other

International Energy Agency

State Governors' Offices

State Energy Offices

State Solar Energy Offices

Statc $\Lambda$ gricultural Offices

State Forestry Offices

Municipal Energy Offices

3.4 Government Solar-Concerned Organizations

Gencral Services Administration (GS $\Lambda$ )

Department of Defense (DOD)

Small Business Administrative (SBA)

USDA-Rural Electrification Administration (REA)

Internal Revenue Service (IRS)

Council on Environmental Quality (CEQ)

Bureau of Alcohol, Tobacco, and Firearms

U.S. Department of Transportation (DOT)

U.S. Department of Interior (DOI)-Bureau of Land Management (BLIM)

General Accounting Office (GAO) 
Table 2-1. BIOMASS ENERGY SYSTEMS INFORMATION USERS (Continued)

3.5 Nongovernment Solar-Active Organizations

Solar Trade Associations

Solar Professional Societies

Solar Public Interest Groups

The Alternate Energy Institute

Wood Energy Institute

Bio-Energy Council

Complete Tree Institute, U. of Maine

National Gasohol Commission

Biomass Energy Institute, Inc.

New England Solar Energy Congress

Solar Lobbyists

3.6 Nongovernment Solar-Concerned Organizations

Public Interest Organizations

Environmental Organizations

Future Farmers of America

Chambers of Commerce

Nonsolar Professional Societies

National Solid Waste Management Association

Ameriean Chemical Society

Nonsolar Trade Associations

Forest Industrial Council

National Cattlemen's Association

American Pulpwood Association

American Paper Institute

Farmer Co-ops

American Farm Bureau Federation

Farmer's Education and

Cooperative Union of America

Home Improvement Associations

3.7 Regulatory, Codes, or Standards Community

EPA

Occupational Safety and IIealth Administration (OSIIA)

American National Standards Institute (ANSI)

American Society of Mechanical Engineers (ASME)

Federal Drug Administration (FDA)

Better Business Bureaus

Building Inspectors

3.8 Utility Community

Municipally Owned Gas and Electric Utilities

Electric Power Companies

Gas Utilities

National Association of

Regulatory Utility Commissioners

State Utility Commissions 
Table 2-1. BIOMASS ENERGY SYSTEMS INFORMATON USERS (Continued)

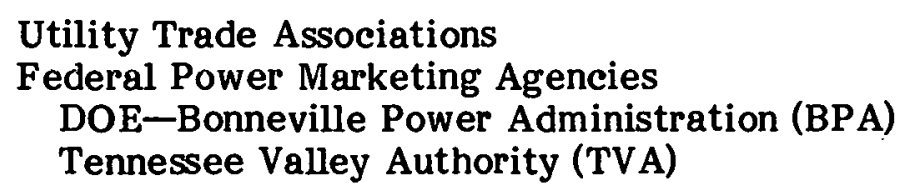

3.9 Financial Community

Bankers

Venture Capital Brokers

Government Loan Agencies

USDA-Farmer's Home Administration (FHA)

USDA-Commodity Credit Corporation (CCC)

Stock Brokers

3.10 Legal Community

3.11 Real Estate Community.

3.12 Insurance Community

Management

Agents

Actuaries

3.13 Educational Community

High School Science Teachers

University Faculty

Vocational Instructors

Career Counselors

Seminar Organizers and Instructors

3.14 Information Intermediaries

Federal Technical Libraries

Industrial Technical Libraries

Academic or Nonprofit Technical Libraries

Public Libraries

Federal Information Centers

On-Line Inf ormation Services

Bookstores

Film Distributors

\subsection{Media}

Newspapers or Magazines

Technical and Trade Journals

Television

Radio

Book Publishers

Newspaper Farm Editors of Ameriea 
Table 2-1. BIOMASS ENERGY SYSTEMS INFORMATION USERS (Concluded)
3.16 Labor Organizations
Steam fitters' Unions
Construction Unions
Farmworkers' Unions

4.0 Users or Prospective Users

4.1 Government, Commercial, or Industrial Users

DOD

Owners of Large Transportation Fleets

Electric Utilities

Industries Requiring Ammonia

Gas Utilities

Glass Manufacturers

Industrial Process Heat Users

Industries Requiring Gaseous Fuels

Industries Using Boilers

Food Processing Industry

Pulp and Paper Industry

Logging Industry

Forest Products Industry

Other Industries Producing Organic Waste or Refuse

Owners of Large Buildings or Complexes

Owners of Small Buildings

Owners of Remote Facilities

4.2 Residential or Farming Users

Homeowners

Custom Homes

Speculative Houses

Retrofits

Farmers, Ranchers

Car Owners

Mobile Home Owners

Remote Facility Owners

5.0 General Public

Secondary School Students

College Students

Adults 


\subsubsection{Groups Included in the Biomass Energy Study}

After all decision criteria and constraints had been applied, it was determined that studies of the following 12 groups would be conducted to ask respondents about their need for information on biomass energy:

- Federally Funded Researchers involved in the Production and Collection (P\&C) of biomass energy feedstock,

- Nonfederally Funded Biomass P\&C Researchers,

- Federally Funded Researchers involved in the Conversion of biomass feedstock to energy,

- Nonfederally Funded Biomass Conversion Researchers,

- Representatives of Manufacturers of (agricultural or forest) Biomass Production and Collection Equipment,

- Representatives of Manufacturers of Biomass Conversion Equipment,

- Representatives of State Forestry Offices,

- Private Foresters who have been involved with biomass energy,

- Forest Products Engineers and Consultants interested in biomass energy,

- Educators teaching college-level courses in biomass energy,

- Cooperative Extension Service (CES) County Agents who will be needing information on biomass energy, and

- Biomass Energy System Managers.

The results from these studies are reported in Sections 3.0 through 10.0. Groups considered for the study, but for whom adequate sample frames could not be obtained, included producers of ethanol for gasohol, gasohol distributors, and designers of biomass conversion systems.

\subsubsection{Biomass-Concerned Groups Included in the General Solar Study}

Additionally, as a part of the overall study a number of groups were queried about their need for information on solar energy in general, rather than on a specific technology like biomass energy. While it was determined that all respondents in these groups had some involvement with solar energy, for many of them it was likely that this involvement was not, nor would it become, a primary factor in their professional work. Rather, for mostif not all-of them, solar energy was a new but minor issue which they were beginning to address within the scope of their existing jobs. Because each of these groups had peripheral interests in more than one solar technology, yet had not yet become fully involved with any, they were asked for general solar information needs rather than technologyspecific solar information needs.

The results of the general solar study are reported in another document [2]. For biomass energy the following five groups were especially relevant because for each group at least four of the nine respondents indicated biomass energy was one of the areas in which they were "particularly interested in obtaining information:"

- Real Estate Appraisers,

- Insurers, 
- Public Interest Groups,

- Information specialists at State CES Offices, and

- Agricultural engineering specialists at State CES Offices.

The general solar energy report [2] also discusses the results of studies in which state solar/energy office representatives were asked about their general, rather than technology-specific, solar information needs. More than $85 \%$ of these respondents expressed an interest in biomass energy systems.

\subsection{DATA INTERPRETATION}

This subsection describes several points the reader should keep in mind in interpreting the data and results presented in the following sections.

\subsubsection{Impact of the Sample Frames: Who was Sampled?}

There were several ways in which the method of constructing the sample frames impacted the data. First, in some of the sample frames one geographic region was relatively over-represented, while another was relatively under-represented. For a study of sample size nine, however, such biases were generally not bothersome since the results were principally qualitative rather than quantitative:

Second, the sample frames were only as good as the sources. For example, the Smithsonian Science Information Exchange (SSIE) data base and DOE's Research in Progress (RIP) data base were principal sources in developing lists of researchers. The SSIE was not always up-to-date, of ten did not include the name of the correct principal investigator; and did not contain much of the nonfederally funded research. RIP had similar problems, varying greatly in quality according to which technology was involved. Each of these problems could cause biases as to which researchers were included and which were excluded from the samples.

Third, many arbitrary decisions were necessary in developing the sample frames. For example, it was important not to interview a respondent more than once, even if he or she was working in more than one technical area. Thus, if Researcher $X$ at Company $Y$ was listed as principal investigator both for one project in biomass and for another in passive, then $X$ was arbitrarily assigned to one of the two technologies, usually to the one with the smaller set of names.

The most important advice for the reader is to study carefully the description of how the sample frame was developed for each individual group. Often a generic title was assigned to a group; the reader must review sample frame development carefully to understand just who was being studied.

\subsubsection{Statistical Tests}

The statistical tests used are described in Appendix E. In the following sections test results are reported only if the statistical tests were significant at the $\mathrm{P}<0.05$ level. Thus, if a test result indicated that a difference between two means was statistically significant $(P<0.05)$, it meant that there was a maximum of a $1-i n-20$ chance that the two means were not different. 


\subsubsection{Hypotheses Versus Conclusions}

Because of the limitations of sample size it was not always possible to draw definitive conclusions. In certain cases, when definitive conclusions could not be drawn, the authors have instead formed hypotheses based upon the results.

\subsubsection{Significance of Rankings}

One of the most valuable results of this study was the development of a ranked list of information topics or products which would be useful to the members of each group (for example, see Fig. 3-1). Typically, statistical significance tests (see Appendix E) indicated that the four-to-six top-ranked items were rated significantly higher than the bottom four-to-six items. Thus, typically there was no statistically significant difference between the top-rated item and the second-rated item-or even between the top-rated and the fourteenth-rated item. If the sample size häd been greater, the number of cum* binations in which one item was rated significantly higher than the other would also have been greater. Even if every sample size had been raised by a factor of 10 , however, it is highly unlikely that all pairs of items would have had significantly different ratings.

How, then, should the reader treat two items which were not significantly different in rating? Was there any meaning to the ranking system?

Yes, the fact that there were statistically significant differences between the top-rated and the bottom-rated items established the validity of the ranking scale as a whole. Despite the fact that two ratings are not significantly different, they still have the statistical property of being the Best Linear Unbiased Estimators. For example, even if Item 1 (with a rating of 3.4) was not significantly greater than Item 2 (with a rating of 3.1), Item 1 should still be considered the more important need unless there is additional, outside information to the contrary. (In determining which information products to develop, of course, one must also consider additional factors such as the cost of the product, the proportion of the group which will be reached, and the degree to which the information need will be met.)

\subsubsection{Alternative Measures of Usefulness}

The ranking of selected information items (In usefulness to the respondent) was bused upon the rating developed by assigning a "4" for each response of "essential," a " 3 " for "very useful," a "2" for "somewhat useful," and a "l" for "not at all useful;" summing the responses for the entire group; then dividing by the number of responses in the group. Using the rating was the preferable way to establish rankings within a group because it fully used the information on the differences between "essentlal" and "very useful," between "somewhat useful" and "not at all useful."

There were several alternative ways of comparing the usefulness of items, one of which was to calculate the percentage of respondents who classified the item as either "essential" or "very useful." Using this percentage was quite handy in considering how useful a product designed for more than one group would be. For example, both "a calendar (of solar events)" and "lists of local lenders (etc.)" were examples of information products that would be designed for many groups to use. In comparing the two potential products as to usefulness, this method (calculating for each item the percentage of respondents who considered the item either "essential" or "very useful") provided a much more meaningful comparison than, for example, summing the ranks for all groups. 


\subsubsection{Combining Results From Different Groups}

It should be pointed out that combining results from all biomass energy groups interviewed will not provide unbiased estimates of the total biomass energy community. First, the proportions of respondents from one group interviewed in this study may not correspond to the proportion of such persons in the entire community. Second, the pecur liarities of each individual sample frame were responsible for varying degrees of bias for each group. Third, some of the important groups in the biomass energy community were not studied (see Seetion 2.2).

Great care should be exercised in interpreting results from a combination of groups. It is too easy to get the impression that one product can fully meet the needs of all groups when, in fact, it may only partially meet the information needs of some of the groups involved.

\subsubsection{Specific Information Products}

Several specific information products were included among the items for which usefulness was assessed. It is important that responses to these items not be interpreted as totally generic responses. People who gave "a bibliography of general readings on biomass energy" a low rating may have done so either because of the level and content of the subject matter (i.e., general readings on biomass energy) or because of the format. (i.e., bibliography). These people may or may not want bibliographies on other topics. '

\subsubsection{Information Sources}

Another important question investigated how many respondents had used specific information sources. In using these results to plan how specific information is to be transmitted, it will be essential to specify fully both the information products or services and the groups to be reached before making the final decision of which information channels are to be used. One cannot assume, for example, that the two or three top-rated sources should be used for all, or even most, of the information transmissions to the group.

There were two other issues related to this question. The first was the decision not to ask respondents whether they had used SERI as an information source. The reasons are discussed in Appendix D.

The second issue concerned possible bias in responses to the question "have you obtained any solar information directly from the U.S. Department of Energy?" The intent of the question was to find out if respondents had contacted DOE directly for information, rather than if they had obtained DOE-produced information from other sources [such as SERI, Government Printing Office (GPO), National Technical Information Service (NTIS), National Solar Heating and Cooling Information Center (NSHCIC), Regional Solar Energy Centers (RSECs), libraries, etc.] There was, however, no assurance that respondents interpreted the question in this light. In cases where the response "directly from DOE" was high, there was the possibility that respondents were referring to information authored or funded by DOE, but obtained from some other source. 


\section{SEFI}




\section{SECTION 3.0}

\section{BIOMASS RESEARCHERS}

\subsection{DESCRIPTION OF RESPONDENTS}

\subsubsection{Description of Sample}

This section describes the results of four telephone studies to determine the needs of researchers for information on biomass energy systems. In all, 36 Biomass Researchers were interviewed as follows:

- 8 Federally Funded Biomass Production and Collection Researchers (Fed P\&C Researchers),

- 9 Nonfederally Funded Biomass P\&C Researchers (Nonfed P\&C Researchers),

- 10 Federally Funded Biomass Conversion Researchers (Fed Conv Researchers), and

- 9 Nonfederally Funded Biomass Conversion Researchers (Nonfed Conv Researchers):

After the respondents were interviewed, it was discovered that the P\&C Researchers were of ten also involved in conversion projects. The Conversion Researchers, however, generally did not work on P\&C projects.

The sample frames for all four groups were selected from the Bio-Energy Directory [3] In cases where a researcher's name was listed for more than one project, duplicates were eliminated. In addition to eliminating duplicate names from the Directory, all names which were duplicates of those in the solar Agricultural or Industrial Process Heat Researcher sample frames were eliminated from consideration in Biomass Researcher sample frames. Duplicates were individuals' names rather than organizations' names so the same organization may still have been sampled more than once. This, in fact, did occur in the final set of randomly selected interview candidates. One organization was encountered twice among the Nonfed P\&C Researchers respondents, another organization was encountered among respondents for both Fed and Nonfed Conv Researchers.

The sample frames for the two $\mathrm{P} \& \mathrm{C}$ groups were constructed from the sections in the Directory on "Biomass Sources,"* and selections from "Bio-Energy Assessments" and the Appendix. The Appendix included recent (but not necessarily current) research. All nonU.S. researchers were eliminated from consideration. In distinguishing between federally funded and nonfederally funded researchers, the following criteria were used: researchers receiving funding from both sectors were considered federally funded; U.S. Department of Agriculture (USDA) Agricultural Experiment Stations were considered federally funded. After all adjustments were made, the 8 interview candidates for Fed P\&C Researchers were randomly selected from a sample frame of 170 names; the 9 interview candidates for Nonfed P\&C Researchers were randomly selected from a sample frame of 201 names.

*It should be noted that "Biomass Sources" included subsections on photosynthesis, terrestrial biomass, terrestrial biofluids, aquatic biomass, and refuse-derived fuels. 
The sample frames for the two conversion groups were constructed from the sections on "Microbial Conversions," "Thermal Conversions,"* "Alcohol Technology," and selections from "Bio-Energy Assessments" and the Appendix. Eliminations, handling of duplicates, and distinctions between federally and nonfederally funded were handled the same as for P\&C Researchers. After all adjustments were made, the 10 interview candidates for Fed Conv Researchers were randomly selected from a sample frame of 95 names; the 9 interview candidates for Nonfed Conv Researchers from a sample frame of 154 names.

Respondents. In making the telephone calls to contact the randomly selected interview candidates, it sometimes occurred that the person could not be reached. In this event another randomly selected name was substituted for the original name. When individuals were contacted it was verified that they had been involved in the type of biomass research specified for that sample frame (production and collection, or conversion), that the funding source was as specified for that sample frame (an individual who received any federal funding for biomass research was considered federally funded, and therefore an inappropriate candidate for a nonfederally funded researcher group), and that they would be needing information on biomass (P\&C or Converslon, as appropriate) within the next year. If they were not both involved and needing information, they were asked if they could refer the interviewer to someone else in their organization who would be an appropriate respondent. If such a referral was made, a call was then mude to this new candidate; if no intraorganizational referral was made, a new candidate was randomly selected from the sample frame. The results of this process may be seen in Table 3-1.

Table 3-1. COMPLETION OP INTERVIEWS: BIOMASS RESEARCHERS

\begin{tabular}{|c|c|c|c|c|}
\hline \multirow{3}{*}{ Event } & \multicolumn{4}{|c|}{ Number of Candidates } \\
\hline & \multicolumn{2}{|c|}{$\mathrm{P} \& \mathrm{C}$} & \multicolumn{2}{|c|}{ Conversion } \\
\hline & $\begin{array}{l}\text { Federally } \\
\text { Funded }\end{array}$ & $\begin{array}{l}\text { Non- } \\
\text { federally } \\
\text { Funded }\end{array}$ & $\begin{array}{l}\text { Federally } \\
\text { Funded }\end{array}$ & $\begin{array}{l}\text { Non- } \\
\text { federally } \\
\text { Funded }\end{array}$ \\
\hline \multicolumn{5}{|l|}{ Interview completed with sample } \\
\hline $\begin{array}{l}\text { Irame candidate } \\
\text { Interview completed with referral }\end{array}$ & 7 & 8 & 9 & 9 \\
\hline candidate & 1 & 1 & 1 & $\mathbf{0}$ \\
\hline Refusal or candidate termination & $\mathbf{0}$ & 0 & 0 & 1 \\
\hline $\begin{array}{l}\text { Contact attempted: could not reach } \\
\text { candidate within three attempts or } \\
\text { before interviews were completed }\end{array}$ & 3 & 1 & 3 & 1 \\
\hline Subtotal & 11 & 10 & 13 & 11 \\
\hline \multicolumn{5}{|l|}{$\begin{array}{l}\text { Contact attempted: invalid candidate } \\
\text { (e.g., inappropriate field of interest, }\end{array}$} \\
\hline TOTAL & 15 & 14 & 15 & 14 \\
\hline Sample frame error rate ${ }^{a}$ (Percent) & 27 & 29 & 13 & 21 \\
\hline Completion rate ${ }^{b}$ (Percent) & 73 & 90 & 77 & 82 \\
\hline
\end{tabular}

Invalid candidates divided by TOTAL

${ }^{b}$ Completed interviews divided by Subtotal

*"Microbial Conversions" included subsections on methane generation and ethanol formation; "Thermal Conversions" included subsections on combustion and pyrolysis. 
Comparisons. For additional insight into the information needs and information habits of these four groups of Biomass Researchers, results from each of these groups are compared to those of the other three groups and to the results from all of the researchers interviewed in this study (All Researchers). The list of the groups contained in All Researchers can be found in Table F-2 of Appendix F. In performing any statistical comparisons, the totals for the group or groups of Biomass Researchers being compared have been subtracted from the totals for All Researchers. Comparisons are also made for each group against Total Biomass Researchers (all 4 groups combined). In addition, the following comparisons are made: Total Fed Researchers ( 2 groups) versus Total Nonfed Researchers (2 groups); and Total P\&C Researchers (2 groups) versus Total Conv Researchers ( 2 groups). The data for each of the groups and combinations can be found in Appendix F.

\subsubsection{Current Status of Respondents}

Role. Three of the Fed P\&C Researchers were employed by universities, 2 by state or local governments, 2 by private research companies, and 1 by the federal government. Among the Nonfed P\&C Researchers, 4 were employed by universities, 3 by state and local government, and 2 by private research organizations. Thus, Total P\&C Researchers were most likely to be employed by universities (41\%).

Among the Fed Conv Researchers, 3 were employed by universities, 2 by the military, 1 by other federal government, 1 by a private research company, and 3 by industry (other than the forest products industry). For Nonfed Conv Researchers, none were employed by universities, the military, nor other federal government; 4 were employed by state and local government; 2 by private research organizations; 2 by the forest products industry; and 1 by other industry.

Current activities of the Fed P\&C Researchers included investigations into: alcohol fermentation, alcohol from cellulose, methane production, ways to convert "biomass plasma" (from aquaculture using wastewater) into methane and fertilizer, feasibility of commercial and residential use of wood energy, growing trees as an energy crop, crop productivity research, wood combustion, and photosynthesis. One researcher was involved in construction of turn-key, wood-fired power plants.

Current activities of the Nonfed P\&C Researchers covered some of the same areas, namely: alcohol fuels (fermentation and gasification), biogas from aquatic plants, methane from algal feedstocks, coppicing, and photosynthesis. Other areas in which they were interested included: biomass energy from crop residues (including energy and environmental costs), feasibility of biomass systems, deriving energy from the "urban waste stream," and production of crops for energy. One researcher had been working on a gasifier and had published in the biomass fuels area.

The range of activities in which these $P \& C$ Researchers were involved points up the difficulties in attempting to separate out those people involved with only production and collection (but not conversion) of biomass for fuel. There was considerable overlap with biomass conversion-although all P\&C Researchers were involved with some phase of biomass production and collection for fuel as well.

Current activities of the Fed Conv Researchers included: general research and development in the biomass energy field, air pollution due to use of biomass fuels, conversion of wood to ethanol, waste research, conversion of biomass to useful chemicals, conversion of biomass to methane, conversion of decomposed plants to gas, encouraging Army use of biomass energy, and providing instruction and specifications. 
Nonfed Conv Researchers were involved in some of the same current activities: conversion of wood to ethanol (enzymatic conversion of cellulose to glucose), waste energy systems, and biomass conversion to methane (from landfills of municipal solid waste including sewage solids). Other areas in which they were involved included: direct combustion; gasification; hydrolysis; fermentation; anaerobic digestion; liquefaction; steam generation by incineration of municipal solid waste and wood wastes; research in self-sufficient energy systems (including use of methane generators, charcoal, and firewood); and construction of biomass conversion plants.

Nota Bene. The principal distinction between the activities of the two groups of $\mathrm{P} \& \mathrm{C}$ Researchers and the activities of the two groups of Conversion Researchers was that all of the P\&C Researchers had some involvement with $P \& C$, but none of the Conversion Researchers did; but while all of the Conversion Researchers were involved with conversion of biomass to energy, so were many ( 8 of the 17) of the P\&C Researchers.

Involvement. Of the four groups, more of the Nonfed P\&C Researchers (8 of the 9) considered themselves "very involved" than did respondents from the other groups (see Table 3-2). Indicating lesser degrees of involvement were Fed Conv Researchers and Nonfed Conv Researchers, while Fed P\&C Researchers had the lowest proportion (4 of the 8 or 50\%) of "very involved" respondents. Total Biomass Researchers (23 of the 36, 64\%) considered themselves to be slightly more involved than did All Researchers (107 of the $181,59 \%)$.

Table 3-2. LEVEIS OF INVOLVEMENT: BIOMASS RESEARCHERS

\begin{tabular}{|c|c|c|c|c|c|c|c|c|}
\hline \multirow{3}{*}{$\begin{array}{l}\text { Biomass } \\
\text { Researcher } \\
\text { Group }\end{array}$} & \multicolumn{6}{|c|}{ Involvement } & \multirow{2}{*}{\multicolumn{2}{|c|}{$\begin{array}{l}\text { Total } \\
\text { Respondents }\end{array}$}} \\
\hline & \multicolumn{2}{|r|}{ Very } & \multicolumn{2}{|c|}{ Moderately } & \multicolumn{2}{|c|}{ Slightly } & & \\
\hline & No. & Percent & No. & Percent & No. & Peroent & No. & ercent \\
\hline $\begin{array}{l}\text { Federally Funded } \mathrm{P} \& \mathrm{C} \\
\text { Nonfederally Funded } \mathrm{P} \& \mathrm{C} \\
\text { Federally Funded Conv } \\
\text { Nonfederally Funded Conv }\end{array}$ & $\begin{array}{l}4 \\
8 \\
6 \\
5\end{array}$ & $\begin{array}{l}50 \\
89 \\
60 \\
56\end{array}$ & $\begin{array}{l}2 \\
0 \\
3 \\
3\end{array}$ & $\begin{array}{r}26 \\
0 \\
30 \\
33\end{array}$ & $\begin{array}{l}2 \\
1 \\
1 \\
1\end{array}$ & $\begin{array}{l}25 \\
11 \\
10 \\
11\end{array}$ & $\begin{array}{r}8 \\
9 \\
10 \\
9\end{array}$ & $\begin{array}{l}100 \\
100 \\
100 \\
100\end{array}$ \\
\hline $\begin{array}{l}\text { Total Production \& Collection } \\
\text { Total Conversion }\end{array}$ & $\begin{array}{l}12 \\
11\end{array}$ & $\begin{array}{l}71 \\
58\end{array}$ & $\begin{array}{l}2 \\
6\end{array}$ & $\begin{array}{l}12 \\
32\end{array}$ & $\begin{array}{l}3 \\
2\end{array}$ & $\begin{array}{l}18 \\
11\end{array}$ & $\begin{array}{l}17 \\
19\end{array}$ & $\begin{array}{l}100 \\
100\end{array}$ \\
\hline $\begin{array}{l}\text { Total Federally Funded } \\
\text { Total Nonfederally Funded }\end{array}$ & $\begin{array}{l}10 \\
13\end{array}$ & $\begin{array}{l}56 \\
72\end{array}$ & $\begin{array}{l}5 \\
3\end{array}$ & $\begin{array}{l}28 \\
17\end{array}$ & $\begin{array}{l}3 \\
2\end{array}$ & $\begin{array}{l}17 \\
11\end{array}$ & $\begin{array}{l}18 \\
18\end{array}$ & $\begin{array}{l}100 \\
100\end{array}$ \\
\hline $\begin{array}{l}\text { Total Biomass Researchers } \\
\text { All Researchers }\end{array}$ & $\begin{array}{r}23 \\
107\end{array}$ & $\begin{array}{l}64 \\
59\end{array}$ & $\begin{array}{r}8 \\
43\end{array}$ & $\begin{array}{l}22 \\
24\end{array}$ & $\begin{array}{r}5 \\
29\end{array}$ & $\begin{array}{l}14 \\
16\end{array}$ & $\begin{array}{r}36 \\
181\end{array}$ & $\begin{array}{l}100 \\
100\end{array}$ \\
\hline
\end{tabular}

Informedness. More of the Nonfed Conv Researchers ( 8 of the 9) considered themselves "very informed" than did respondents from the other three groups (see Table 3-3). Fed P\&C Researchers (6 of the 8) were next, followed by Nonfed P\&C Researchers ( 6 of the 9), then Fed Conv Researchers (6 of the 10). A higher percentage of Nonfederally Funded (14 of the 18, 78\%) than of Federally Funded (12 of the 18,67\%) Biomass 
Researchers considered themselves "very informed." Overall, more of Total Biomass Researchers (26 of the 36, 72\%) than of All Researchers (117 of the 181, 64\%) were "very informed."

Table 3-3. LEVELS OF INFORMEDNESS: BIOMASS RESEARCHERS

\begin{tabular}{|c|c|c|c|c|c|c|c|c|}
\hline \multirow{3}{*}{$\begin{array}{l}\text { Biomass } \\
\text { Researcher } \\
\text { Group }\end{array}$} & \multicolumn{6}{|c|}{ Informedness } & \multirow{2}{*}{\multicolumn{2}{|c|}{$\begin{array}{c}\text { Total } \\
\text { Respondents }\end{array}$}} \\
\hline & \multicolumn{2}{|c|}{ Very } & \multicolumn{2}{|c|}{ Moderately } & \multicolumn{2}{|c|}{ Slightly } & & \\
\hline & No. & Percent & No. & Percent & No. & Percent & No. & Percent \\
\hline $\begin{array}{l}\text { Federally Funded P\&C } \\
\text { Nonfederally Funded P\&C } \\
\text { Federally Funded Conv } \\
\text { Nonfederally Funded Conv }\end{array}$ & $\begin{array}{l}6 \\
6 \\
6 \\
8\end{array}$ & $\begin{array}{l}75 \\
67 \\
60 \\
89\end{array}$ & $\begin{array}{l}2 \\
2 \\
4 \\
1\end{array}$ & $\begin{array}{l}25 \\
22 \\
40 \\
11\end{array}$ & $\begin{array}{l}0 \\
1 \\
0 \\
0\end{array}$ & $\begin{array}{r}0 \\
11 \\
0 \\
0\end{array}$ & $\begin{array}{r}8 \\
9 \\
10 \\
9\end{array}$ & $\begin{array}{l}100 \\
100 \\
100 \\
100\end{array}$ \\
\hline $\begin{array}{l}\text { Total Production \& Collection } \\
\text { Total Conversion }\end{array}$ & $\begin{array}{l}12 \\
14\end{array}$ & $\begin{array}{l}71 \\
74\end{array}$ & $\begin{array}{l}4 \\
5\end{array}$ & $\begin{array}{l}24 \\
26\end{array}$ & $\begin{array}{l}1 \\
0\end{array}$ & $\begin{array}{r}6 \\
0\end{array}$ & $\begin{array}{l}17 \\
19\end{array}$ & $\begin{array}{l}100 \\
100\end{array}$ \\
\hline $\begin{array}{l}\text { Total Federally Funded } \\
\text { Total Nonfederally Funded }\end{array}$ & $\begin{array}{l}12 \\
14\end{array}$ & $\begin{array}{l}67 \\
78\end{array}$ & $\begin{array}{l}6 \\
3\end{array}$ & $\begin{array}{l}33 \\
17\end{array}$ & $\begin{array}{l}0 \\
1\end{array}$ & $\begin{array}{l}0 \\
6\end{array}$ & $\begin{array}{l}18 \\
18\end{array}$ & $\begin{array}{l}100 \\
100\end{array}$ \\
\hline $\begin{array}{l}\text { Total Biomass Researchers } \\
\text { All Researchers }\end{array}$ & $\begin{array}{r}26 \\
117\end{array}$ & $\begin{array}{l}72 \\
65\end{array}$ & $\begin{array}{r}9 \\
59\end{array}$ & $\begin{array}{l}25 \\
33\end{array}$ & $\begin{array}{l}1 \\
5\end{array}$ & $\begin{array}{l}3 \\
3\end{array}$ & $\begin{array}{r}36 \\
181\end{array}$ & $\begin{array}{l}100 \\
100\end{array}$ \\
\hline
\end{tabular}

Need for Information. All 36 Biomass respondents indicated they would need information on biomass (either on production and collection or on conversion, as appropriate for the group) on the job during the next year. Three of the 8 (38\%) Fed P\&C Researchers and 4 of the 9 (44\%) Nonfed P\&C Researchers also expected to need information on biomass production and collection outside the job. Three of the $10(33 \%)$ Fed Conv Researchers and 4 of the 9 (44\%) Nonfed Conv Researchers expected to need off-the-job information on biomass conversion. Total Biomass Researchers were about as likely (14 of the 36, $39 \%$ ) to need off-the-job information as were All Researchers (48 of the 117, 41\%).

\subsubsection{Background of Respondents}

All of the P\&C Researchers held advanced degrees (beyond bachelor's). Two of the 8 Fed P\&C Researchers held master's degrees, 5 held PhDs, and 1 held a law degree. Three of the 9 Nonfed P\&C Researchers held master's degrees, and 6 held PhDs.

Total Conv Researchers (11 of the 19, 58\%) were less likely than were Total P\&C Researchers (17 of the 17, 100\%) to hold advanced degrees. Two of the 10 Fed Conv Researchers held bachelor's degrees, 2 held master's degrees, and 6 held PhD degrees. Only 7 of the 9 Nonfed Conv Researchers had college degrees: 4 bachelor's, 1 master's, and 2 doctor's. Total Fed Researchers were more likely $(16$ of the $18,89 \%)$ to hold advanced degrees than were Total Nonfed Researchers (12 of the 18,67\%). However, Total Biomass Researchers were about as likely as All Researchers to hold advanced 
degrees (78\% and $80 \%$ respectively). For those with degrees, Fed Researchers were more likely to have received their most recent degree (11 of the $18,61 \%)$ within the past 10 years than were Nonfed Researchers (6 of the 16, 38\%).

Degree fields for the four groups were as follows: Fed P\&C Researchers-law, nuclear engineering, chemistry, biochemistry, biology/physiology, plant physiology, environmental science, and forestry; Nonfed P\&C Researchers-agricultural engineering, chemistry (2), biology, microbiology, aquatic biology, plant science, government, and American studies; Fed Conv Researchers-engineering (2: 1 mechanical, 1 architectural), chemistry, bacteriology, biology, physics (2), mathematics, and industrial health; Nonfed Conv Researchers-engineering (3: 1 civil, 1 chemical, and 1 design), biochemistry, forest products, science, and liberal arts. Thus, the Conversion Researchers appeared somewhat more likely to have degrees in engineering than were the P\&C Researchers, but the $P \& C$ Researchers were somewhat more likely to hold degrees in chemical/biological fields than were the Conversion Researchers.

While none of the Fed P\&C Researchers mentioned biomass or energy in describing their current profession, 3 of the Nonfed P\&C group did so. Professions stated by the Fed P\&C Researchers included: environmental lawyer, environmental research scientist, research scientist, plant physiologist, biochemist, chemical engineer, forestry consultant, and corporate executive. Nonfed P\&C Researchers described their professions as: research chemist, biologist (2: 1 acquatic), ecologist, environmental engineer, environmental specialist, biomass consultant, bio-energy specialist, and energy specialist.

Nonfed P\&C Researchers had been in their present profession longer than had Fed P\&C Researchers: five of the 9 in the Nonfed P\&C group had been in their present profession for more than 10 years, as had 3 of the 8 in the Fed P\&C group. While another 3 of the 8 in the latter group had been in their current profession for fewer than 5 years, only 1 of the 9 Nonfed P\&C Researchers had been in their current profession for fewer than 5 years.

Professions given by the Fed Conv Researchers included: mechanical engineer (2: 1 aerospace), microbiologist, biologist, biophysicist, manager (3: 1 business, 1 research, 1 energy research), project leader, and industrial hygienist. Nonfed Conv Researchers described themselves as: engineers (5: 1 mechanical, 2 professional, 2 sanitary), research scientist, manager (2: 1 farm, l technical), and expert in biomass conversion.

As was true for the P\&C Researchers, there was evidence that the Nonfed group had been in their current profession longer than had the federally funded group. None of these Biomass Kesearchers were currently teaching, which was quite unusual among the Researcher groups interviewed in this study.

\subsection{INFORMATION NEEDS OF RESPONDENTS}

\subsubsection{Technical Areas}

Biomass Researchers were asked to choose those areas in which they were "particularly interested in obtaining information" from a list of selected technical areas in biomass energy (see Table 3-4). As expected, Fed and Nonfed P\&C Researchers were more interested in "growth and collection" than in any other area. Fed P\&C Researchers were least interested in "liquid fuels from biomass.". Fed Conv Researchers were most interested in 
Table 3-4. AREAS OF INTBREST: BIOMASS RESBARCHRRS

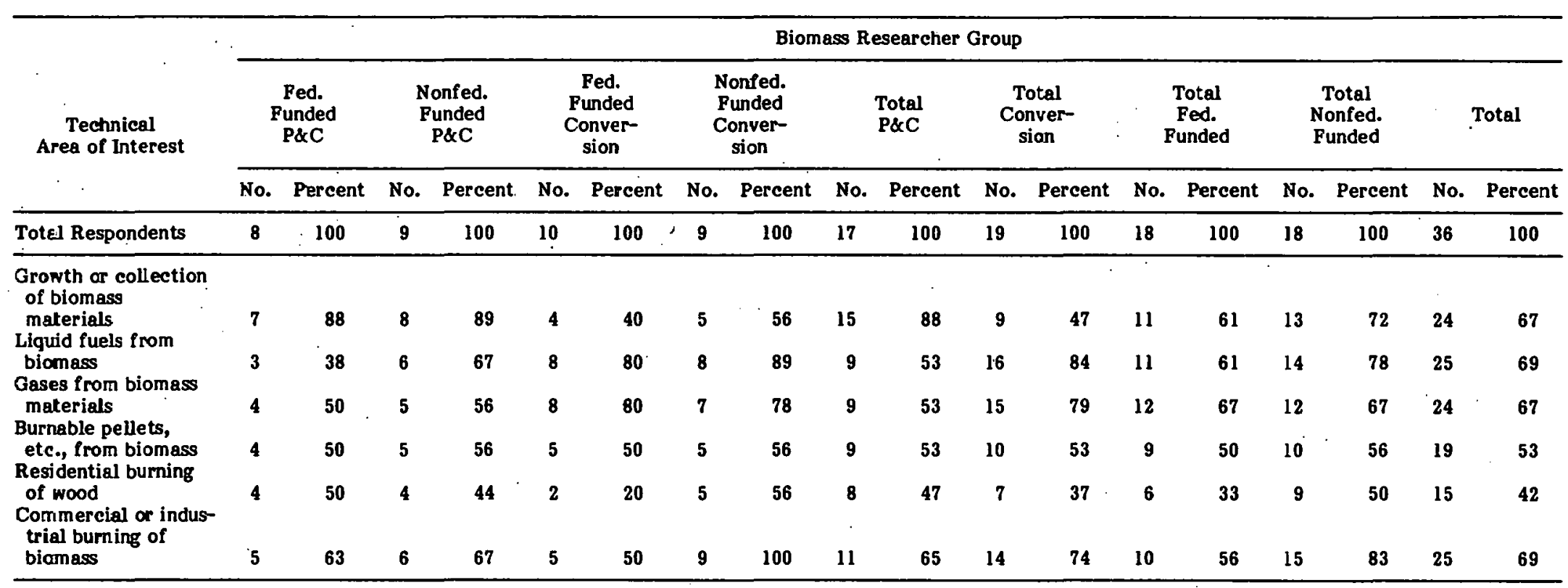


"liquid fuels" and "gases." Nonfed Conv Researchers were most interested in "commercial or industrial burning" as well as "liquid fuels." Relatively, in none of the four groups were the respondents very interested in "residential burning of wood."

\subsubsection{Types of Information}

Biomass Researchers were asked to name the information about biomass technologies that was important for them to obtain. Seven of the 8 Fed P\&C Researchers volunteered one or more items of information which they considered important. Topics included: markets for biomass energy, supply and demand in buying and selling biomass feedstocks and fuels, location of available biomass feedstock, extent of land needed for practical energy system, alternative smaller systems for homes and small commercial buildings, impacts (economic and ecological) of biomass harvesting and use for energy, environmental impacts of wood burning systems, production efficiencies, progress in growing trees as an energy crop, photosynthetic micro-organisms, the chemical composition (carbon, nitro-cellulose, hemocellulose, lignin) of feedstocks in order to evaluate potential for conversion to methane, and biomass energy from aquatic plants. Also specifically mentioned as important were research reports. Eight of the 9 Nonfed P\&C Researchers named the following information topics as important to obtain: technologies and economics of energy conversion and of the utilization of forest products, yields of biomass energy by "natural plant systems," soil erosion rates, winter run-off rates, geographic areas of biomass harvested for energy, influence of nutrients contained in biomass material utilized for energy, lignin content of various biomass feedstocks, optimal production technologies, methane conversion, single cell proteins, commercialization of research results, and funding sources. Information services were also considered important by this group; reports on current activities of researchers in biomass energy including particularly abstracts, abstracting services, and indexes to the literature.

The Fed Conv Researchers mentioned the following as important information: chemicals derived from biomass, marketing information, regional availability of biomass fuels, environmental aspects, identification of plant material rich in nitrogen, the feasibility of fuel production operations, increased production of plant material which can be converted to gas, test results, chemical conversion, breakthroughs in conversion processes (4), new applications, and cost data. The Nonfed Conv Researchers were somewhat more specific in the areas they mentioned: information on commercialization, funding sources, financial incentives, reference books with conversion tables for amount of energy (calories) in different fuel sources, technical charts for use in constructing systems, different processes for incinerating trash to produce steam, current $R \& D$ reports (3), market development of various biomass systems, wood-based biomass fuel systems, gasohol with ethanol, mothano produotion in landfills including ratos of production, wnyn to control rate of production, effects of moisture, procedures for removing carbon dioxide from biogas, the end uses of liquid fuels from biomass, and the air pollution aspects of biomass fuel use including any processes for controlling emissions into the air.

Information which the Fed P\&C Researchers volunteered that they needed but were unable to get included: Denis Meadows/Dartmouth College report on environmental assessment of a 50-MgW wood-burning plant, industrial research results, research reports on environmental quality and legal issues, and data on a variety of biomass systems. Nonfed P\&C Researchers could not obtain information on how a plant (Euphorbia, for example) manufactures oil. One respondent in this group volunteered that the time and cost involved in obtaining and trying to obtain information presented a problem. 
Only 1 Fed Conv Researcher volunteered that there was information he/she needed but could not get: biomass research material from Russia, Germany, and Sweden. Nonfed Conv Researchers volunteered they had not been able to get information on ways to influence methane production in land fills, and ways to remove carbon dioxide from biogas (both also mentioned as important information). One respondent in this group volunteered specific difficulties related to acquiring reports distributed by National Technical Information Service (NTIS): obtaining document numbers, receiving reports on recent research, and contacting the authors while the work was still current.

Choice Between Specific Needs. A list of 11 types of biomass energy information products and 13 types of biomass energy information categories was read to each respondent. Each respondent described the usefulness of each particular item by assigning it a value of "essential," "very useful," "somewhat useful," or "not at all useful." The results are displayed in Fig. 3-1 (Fed P\&C Researchers), Fig. 3-2 (Nonfed P\&C Researchers), Fig. 3-3 (Fed Conv Researchers), and Fig. 3-4 (Nonfed Conv Researchers). For the purpose of comparison, Fig. 3-5 shows results for Total Fed Researchers, Fig. 3-6 for Total Nonfed Researchers, Fig. 3-7 for Total P\&C Researchers, and Fig. 3-8 for Total Conv Researchers. Results for Total Biomass Researchers (all 4 groups) are in Fig. 3-9. Figure 3-10 shows results for All Researchers and is not limited to biomass information items, but cuts across solar research technologies.

Table 3-5 summarizes these results by listing only those items ranked among the top five by one or more groups.

For Total Biomass Researchers the six top-rated information categories/products were:

- The state of the art,

- Research in progress,

- Lists of information sources,

- Lists of technical experts,

- Costs of installing and operating a biomass conversion system compared to a conventional system, and

- Costs and performance of systems.

These items were important to almost all of the biomass researchers. Additionally, each of the following items was important to at least one group of biomass researchers:

- Expected major developments during the next 10 years;

- A technical description of how a particular system works;

- Inștitutional, social, environmental, and legal aspects; and

- Manual methods for sizing and predicting performance or costs.

Compared to the other groups, Fed P\&C Researchers did not give as high ratings to cost information, but gave higher ratings to "institutional, social, environmental, and legal aspects." Nonfed P\&C Researchers gave lower ratings to "a technical description." Neither group of P\&C Researchers was as interested in cost information or in "manual methods" as were the two groups of Conversion Researchers. Of the four groups, Nonfed Conv Researchers gave the highest ratings to cost-related information, but were the only group of the four that was not interested in "lists of information sources." 
Question \#8. I will read a list of potential information or information products on solar systems. For each, please tell me how useful that information would be to you. Would the following be: essential, very useful, somewhat useful, or not at all useful?

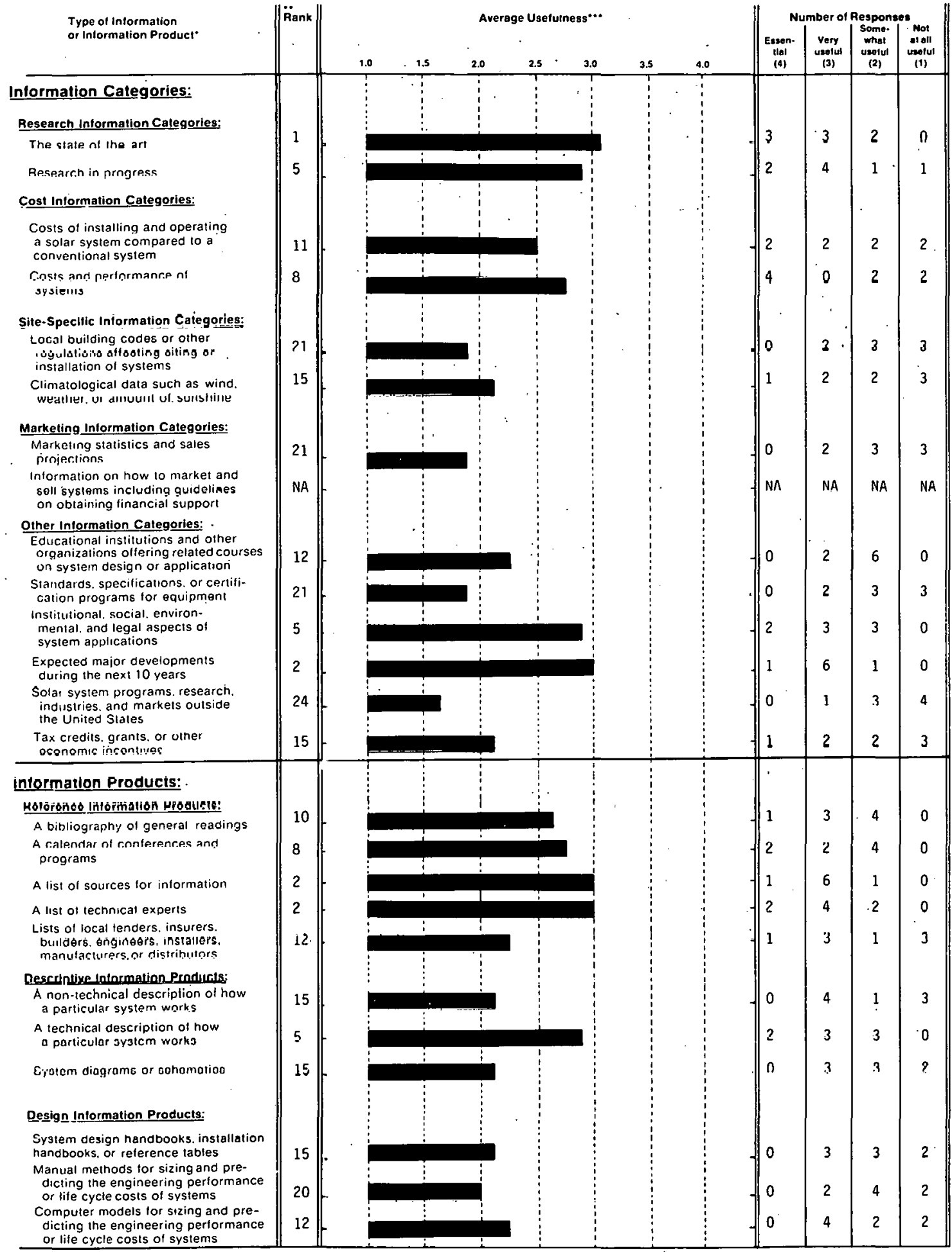

Eacn sample trame of users was questioned on intormation and intormation products in the contexi of ineir specific technology. For example. biomass sample frames were .

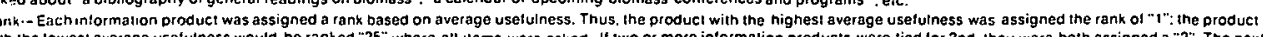
nigins: ranking was then assigned a" a?

Ayerage usaluiness was calculated by assigning ine responses on a 1.4 scate trom a "4" tor "essental" to a "1" "or "not very usetul".

Figure 3-1. Usefulness of Selected Information Items: Federally Funded Biomass Production and Collection Researchers 
Question \#8. I will read a list of potential information or information products on solar systems. For each, please tell me how useful that information would be to you. Would the following be: essential, very useful, somewhat useful, or not at all useful?

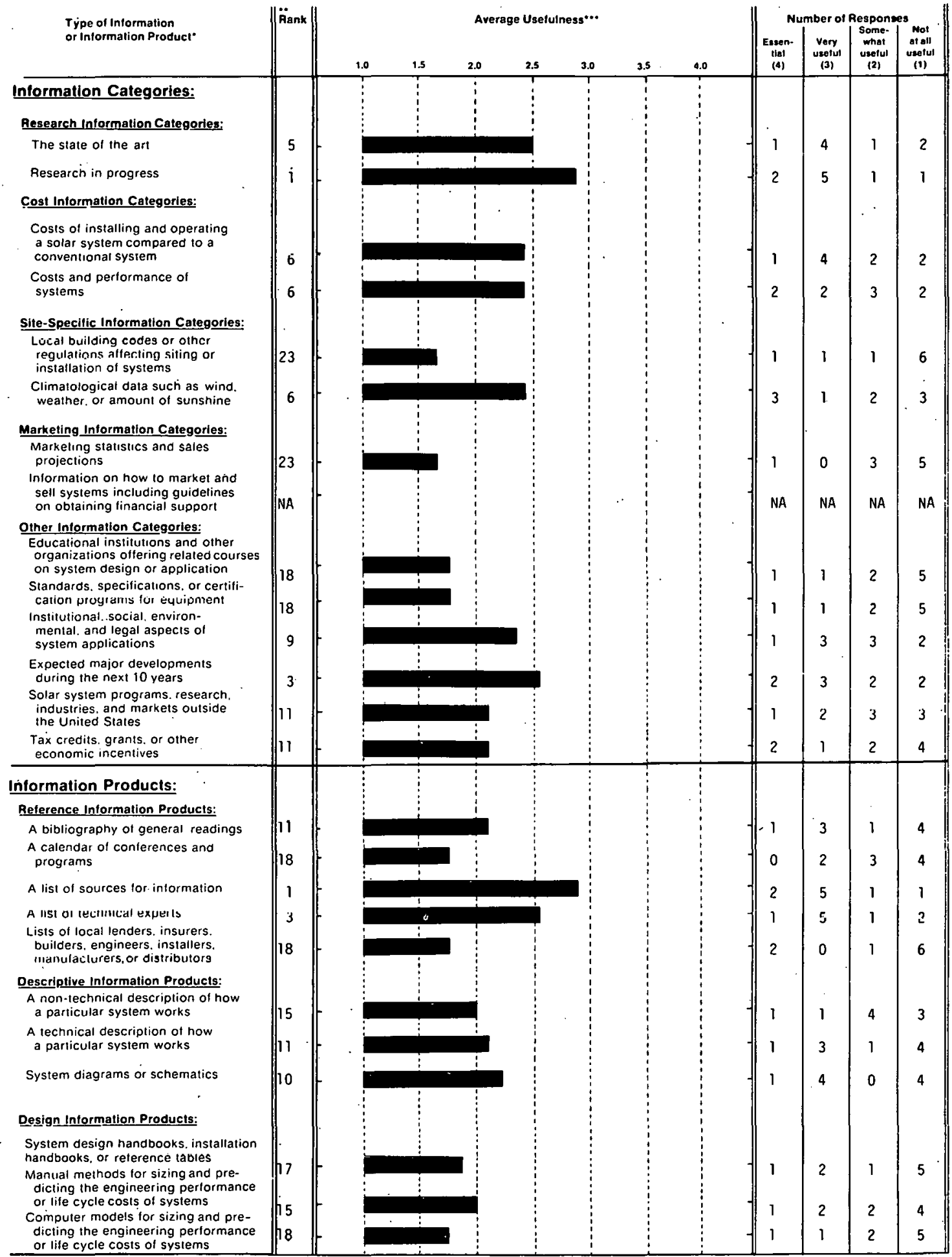

Each sample frame of users was quesioned on intormation ano intormatiun wuduets in the cumtext of their specific technolagy. For oxample. biomass sample framps werp

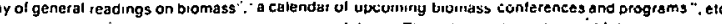
"fank-Each intormation product was assigned a rank based "n as assigned the rank o1 -1": the prortucl

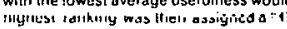

... Average useturness was calculated by assigning the responses on a $1-4$ scale trom a "4" tor "essential to a "i for nol very ustlul".

Figure 3-2. Usefulness of Selected Information Items: Nonfederally Funded Biomass Production and Collection Researchers 
Question \#8. I will read a list of potential information or information products on solar systems. For each, please lell me how useful that information would be to you. Would the following be: essential, very useful, somewhat useful, or not at all useful?

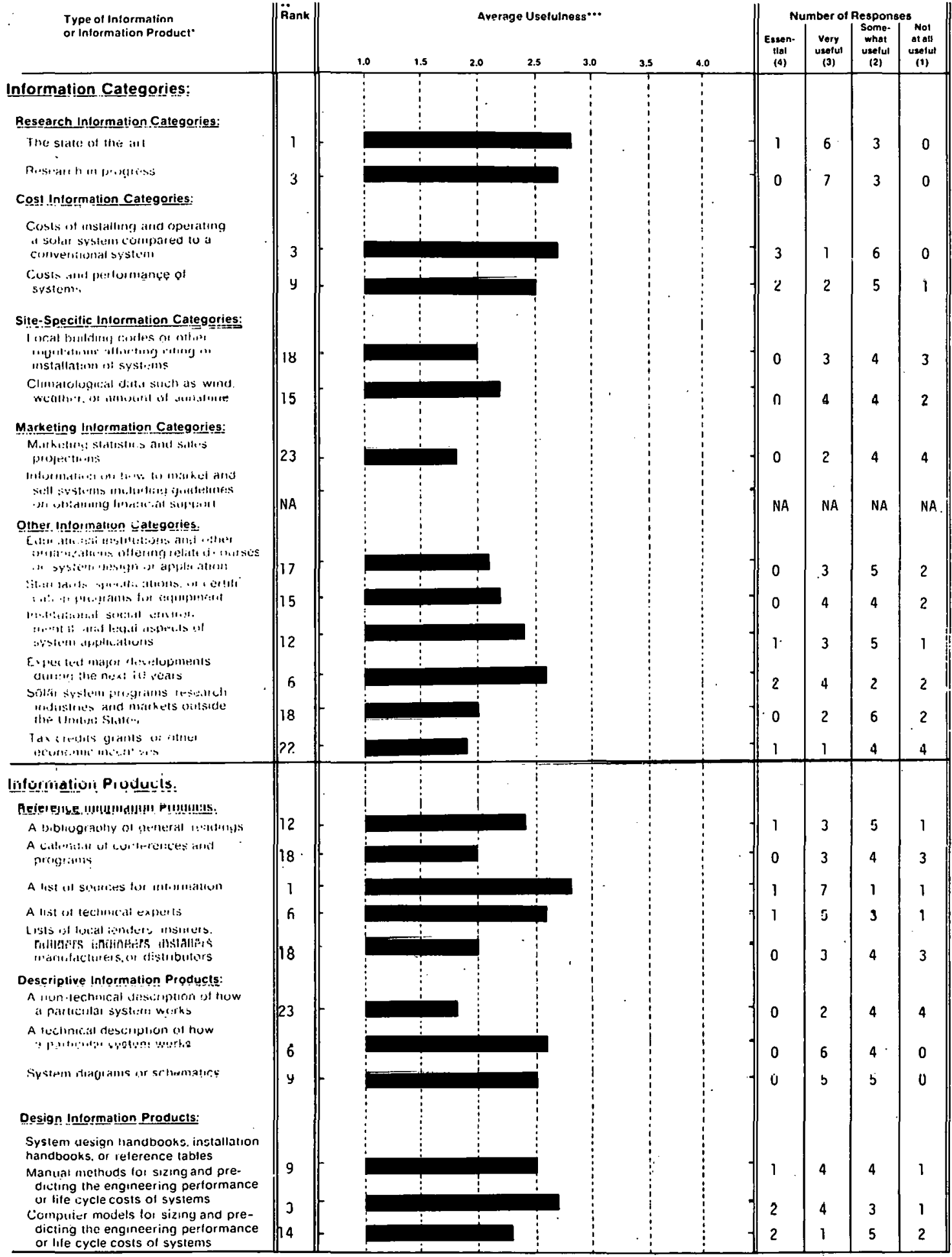

- Eacn sample trame of users was questioned on information and intormation products in the context of their specific tecnnotogy. For example. biomass sampte frames were asked aboul a droliograbny of general readings on biomass . a calendar of upcoming bromass conterences and programs ". etc. " righest ranking was then assigned a"4:

Average usetulness was catculated by assigning the responses on a 1.4 scale trom a " 4 " for "essential" 10 a " "1 " tor "not very useful".

Figure 3-3. Usefulness of Selected Information Items: Federally Funded Biomass Conversion Researchers 
Question \#8. I will read a list of potential information or information products on solar systems. For each, please tell me how useful that information would be to you. Would the following be: essential, very useful, somewhat usclul, or not at all useful?

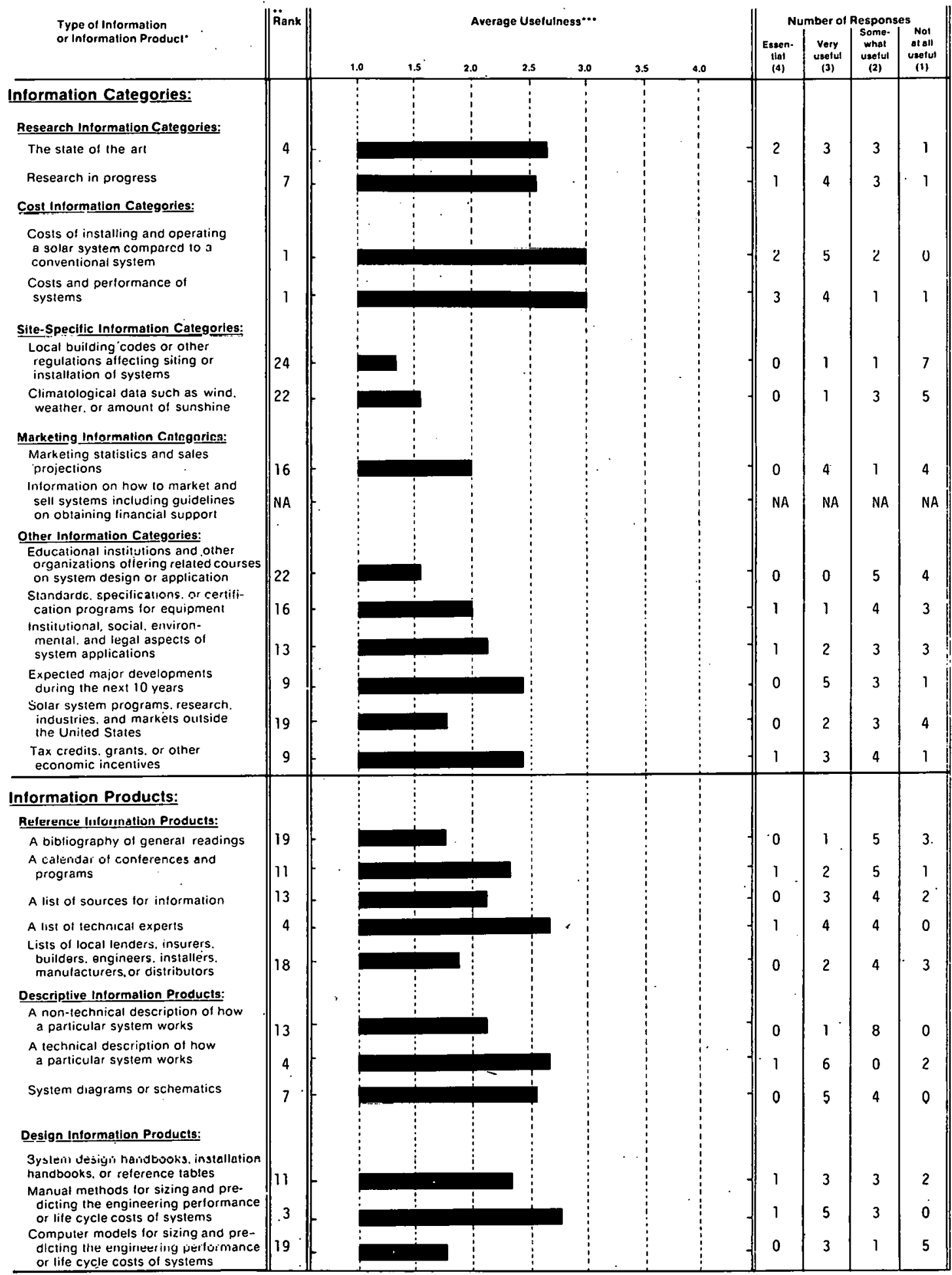

Eacn sample frame of users was questioned an intormation and inlormation products in ine context of their specific lechnology. For example, biomass sample lrames were

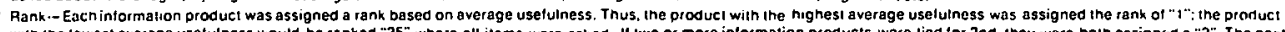
wiln ine lowest average usetulnegs would ber
hignes! ranking wats then assigned a $-4:$ :

.. Average usetulness was catculated by assigning ine responses on a i-4 scale from a " "4" lor "essential" to a "1" tot "not very useful

Figure 3-4. Usefulness of Selected Information Items: Nonfederally Funded Biomass Conversion Researchers 
Question \#8. I will read a list of potential information or information products on solar systems. For each, please tell me how useful that information would be to you. Would the following be: essential, very useful, somewhat useful, or not at all useful?

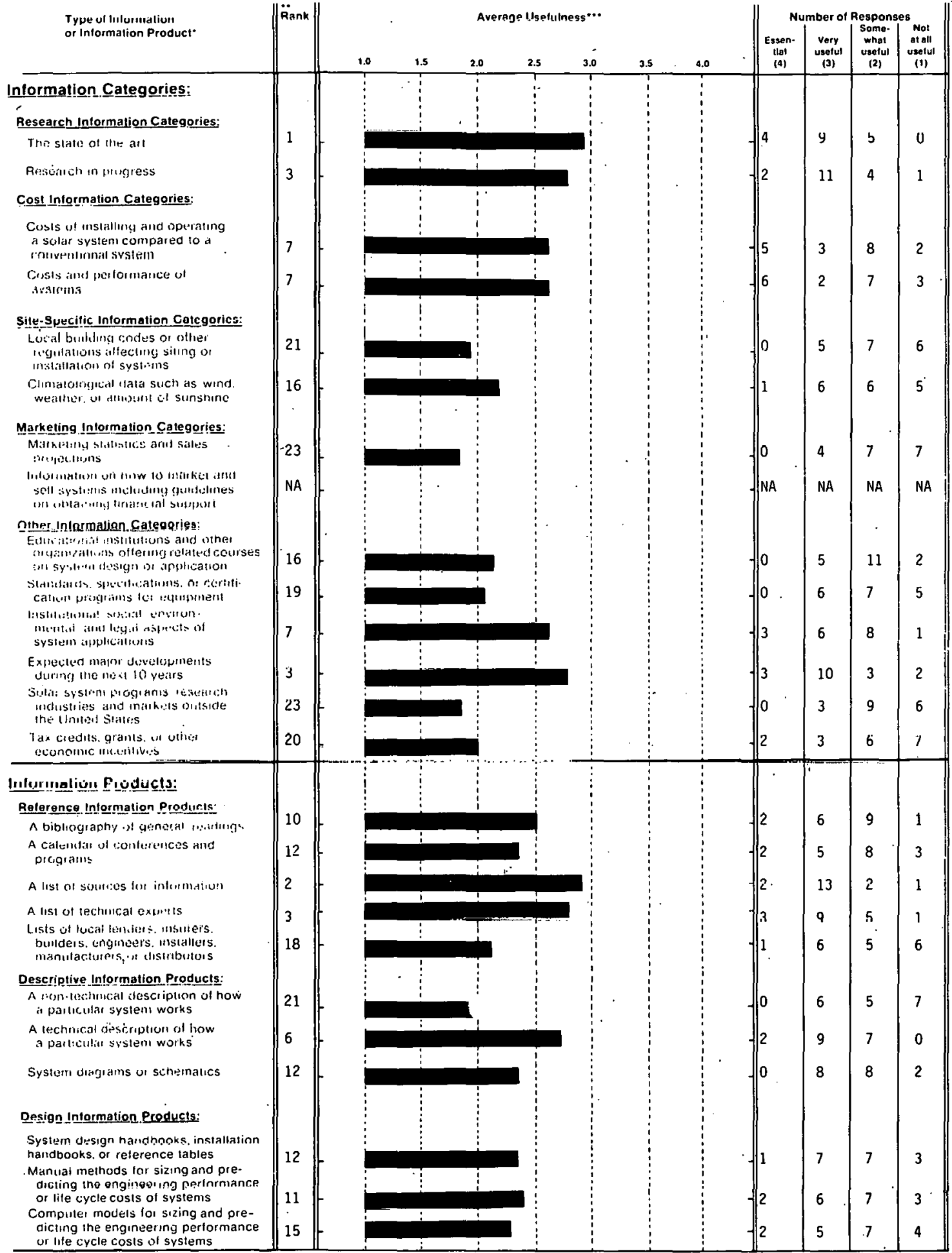

Each sample trame of users was questioned on, ynlormation and intormation producls in the context of their specific technology. For example. biamass sample lrames were "ashed aboin ra bibor

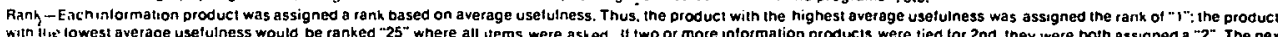
Imuntes: ranking was then assigned a -A"

Aretage usetutness was calculated by assigning the responses on a 1 -4 scale trom a "4" tor "essential" to a " " " tor "not very usetul"

Figure 3-5. Usefulness of Selected Information Items: Total Federaliy Funded Biomass Researchers 
Question \#8. I will read a list of potential information or information products on solar systems. For each "please tell me how useful that information would be to you. Would the following be: essential, very useful, somewhat useful, or not at all useful?

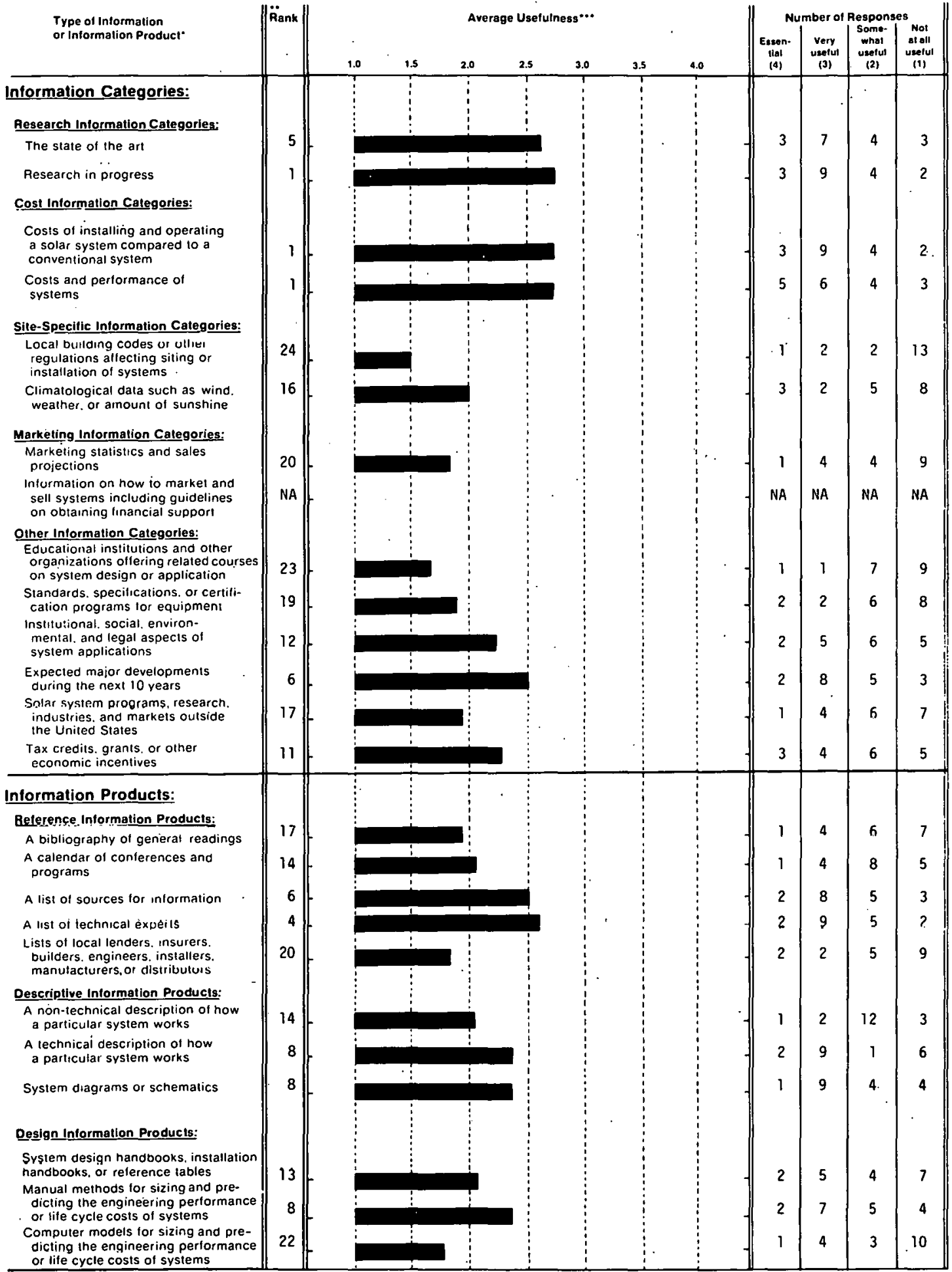

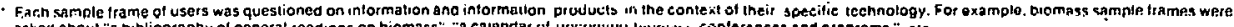
askeu about "a bibliography of general readings on biomass". "A cautendar of upcorminy biurness conterences and programs ", eic.

Rant-Ejchintormation producl was assigned \& rank based on average usetulness. Thus., the product with the highest average usefuiness was assigned the rank of " 1 ": I he product with the lowes average uselliness would be ranked "2s" where all htems were a shed if two or more information producls were tied tor 2 nd. Ihey were boin assigned a " 2 " The ne

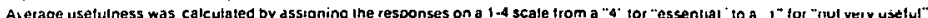

Flgure 3-6. Usefulness of Selected Information Items: Total Nonfederally Funded Blomase Researchers 
Question \#8. I will read a list of potential information or information products on solar systems. For each, please tell me how useful that information would be to you. Would the following be: essential, very uselul, somewhat useful, or not at all useful?

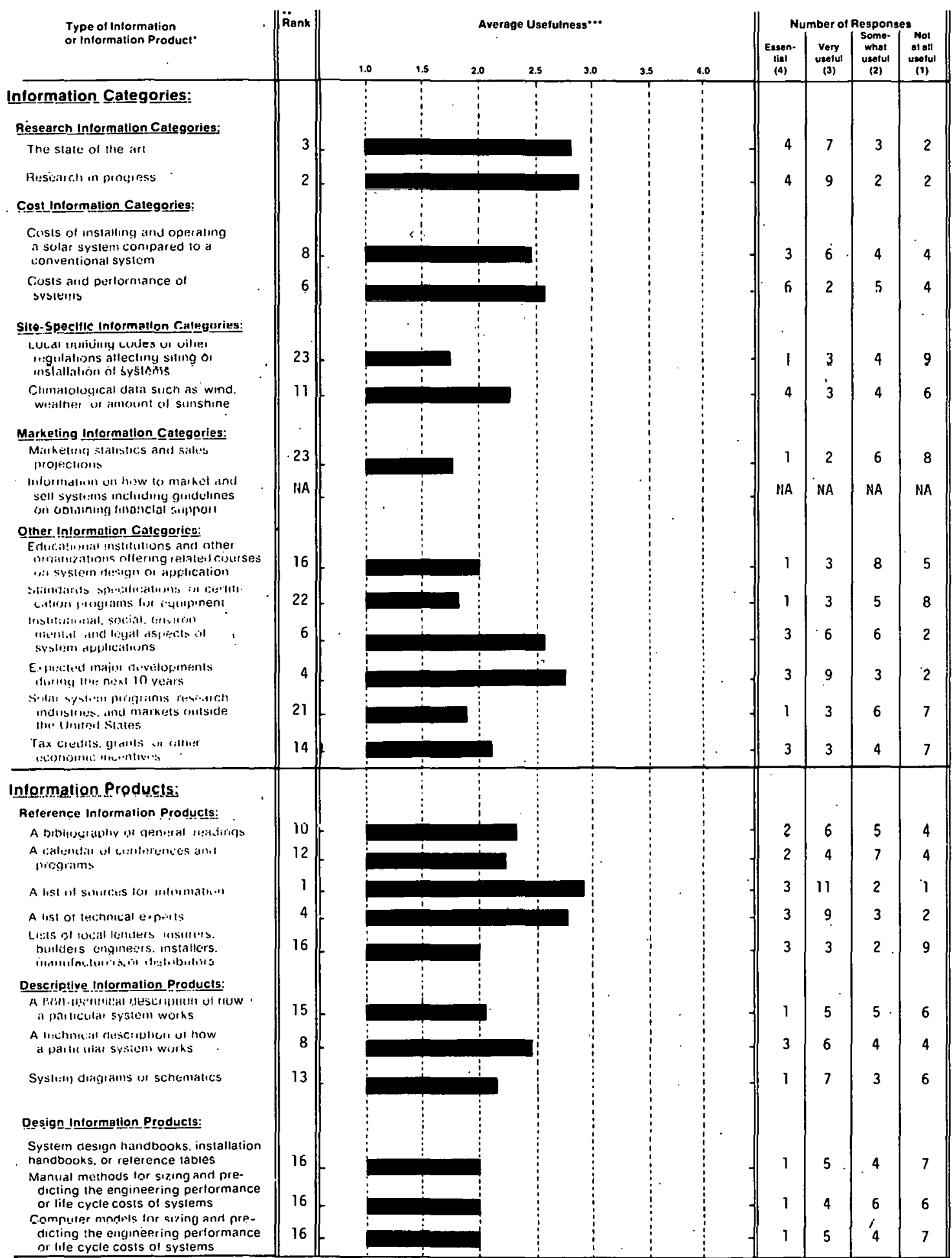

Eacn.sampir frame of users was questioned on unformation and intormation producis in the context ol their specilic lechnology. For exempte. biomass sample irames were asked about "a bibliography of general readings on biomass"." a calendar ol upcoming bromass conferences and programs" ".eic.

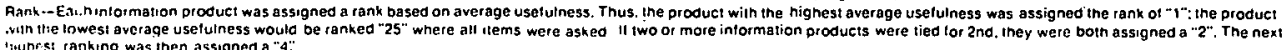

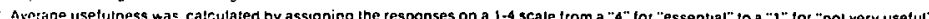

Figure 3-7: Usefulness of Selected Information Items: Total Biomass Production and Collection Researchers 
Question \#8. I will read a list of potential information or information products on solar systems. For each, please tell me how useful that information would be to you. Would the following be: essential, very useful, somewhat useful, or not at all useful?

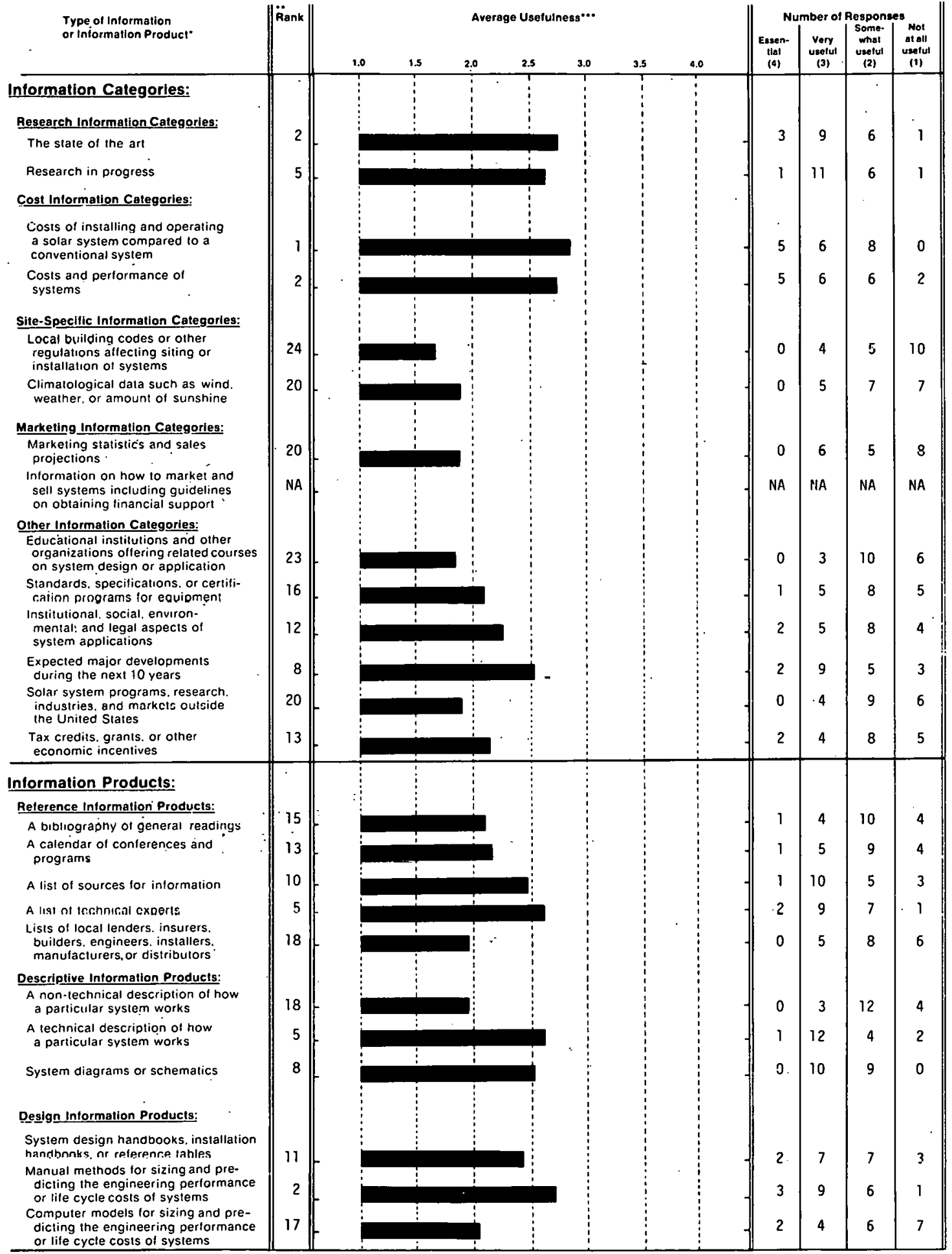

Each samplip liame of users was ouestioned on intormation and intormation products in the context of therr specitic technology. For example. biomass sample trames were

"Rank - Eachinlormation product was assigned a rank besed on average uset winess. Thus. the producl with the nignest average useful hess was assigned ine rank of "1": the product with the lowesl average usefulness would be ranked "25" where all iterns were asked if two or more intormation products were tied for 2 nd, they were both assigned a "2". The ne thighest ranking was inen assigned a " 4 "

Figure 3-8. Usefulness of Selected Information Items: Total Biomass Conversion Researchers 
Question \#8. I will read a list of potential information or information products on solar systems. For each, please iell me how useful that information would be to you. Would the following be: essential, very useful, somewhat useful, or not at all useful?

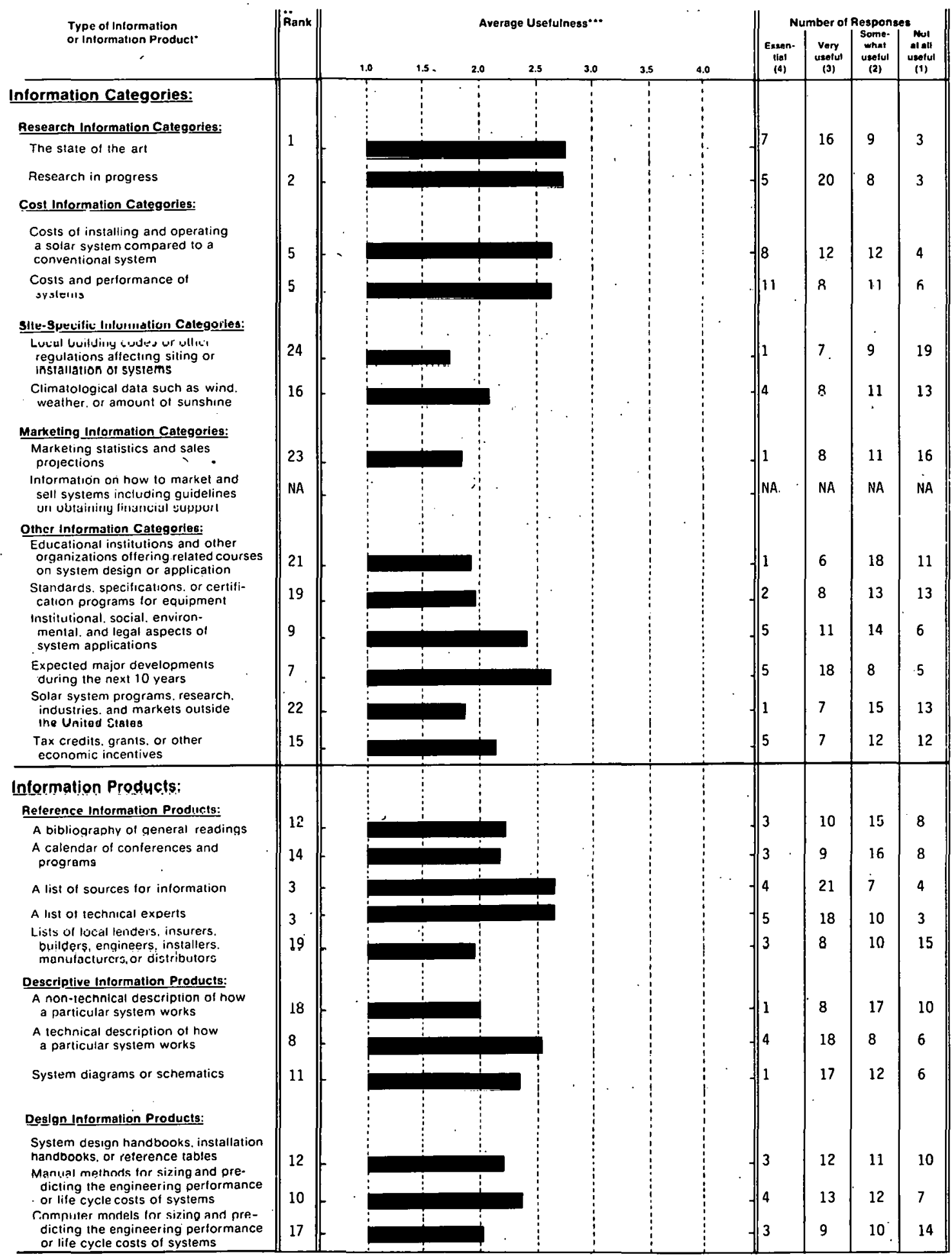
- Each sample irame of users was questioned on intormation and intormation products in the context of their specific technology. For example, biomass sample trames were
asked aboul "a bibliography of general readings on biomass"." a calendar of upcoming biomass conterences and programs ". elc. Rank - Each information product was assigned a rank based on average usefulness. Thus, the product with the highest average usetulness was assigned the rank of " 1 ": the product with the lowest average usefulness would be ranked "25" where all items were asked. 11 two or more intormation producls were tied tor 2 nd. they were both assigned a " 2 ". The next

... Ayerage useituiness was calculated by assigning the responses on a 1 -4 scale trom a "4" tor "essential" to a "1" for "not very usetul".

Figure 3-9. Usefulness of Selected Information Items: Total Biomass Researchers 
Question \#8. I will read a list of potential information or information products on solar systems. For each, please tell me how useful that information would be to you. Would the following be: essential, very useful, somewhat usefui, or not at all useful?

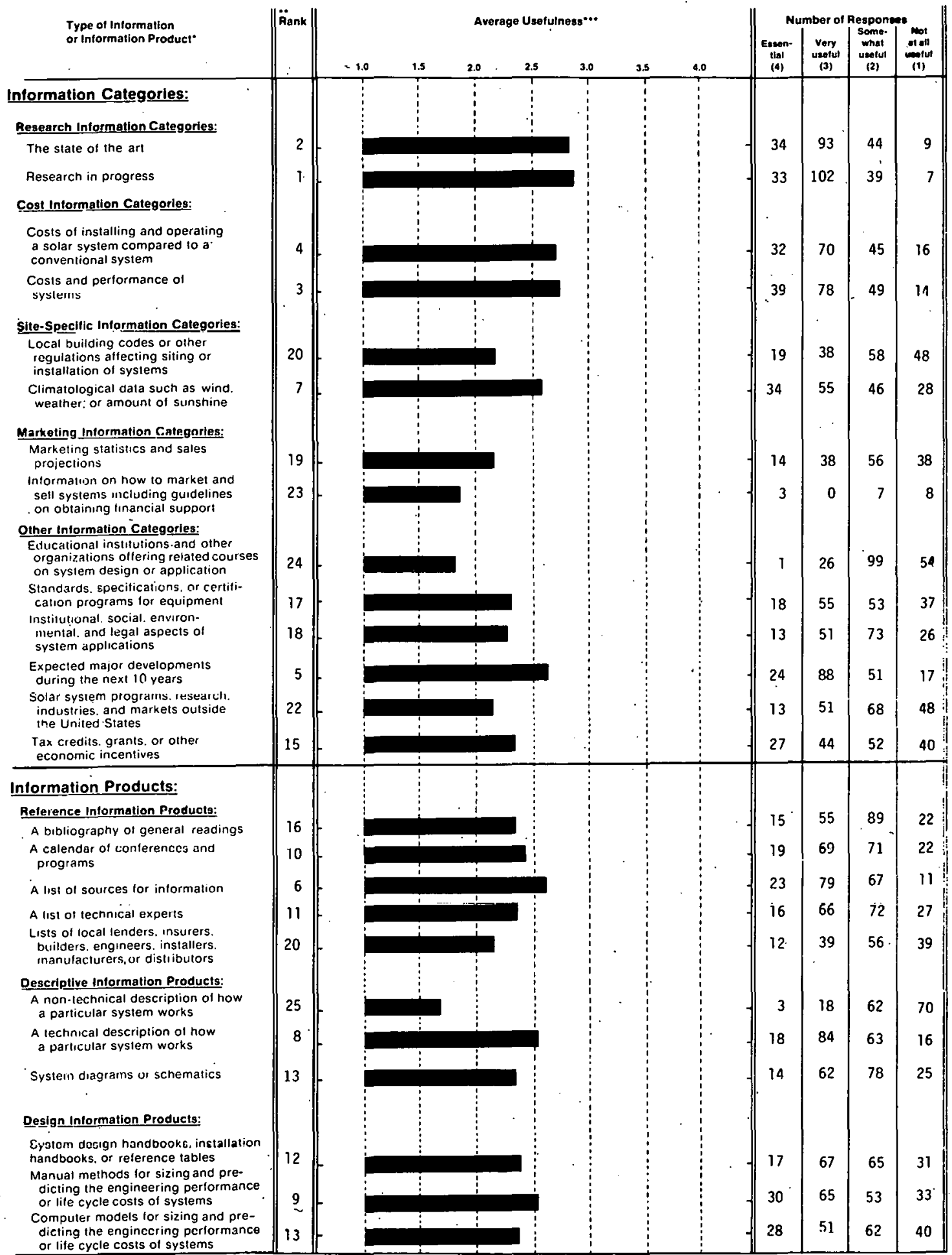

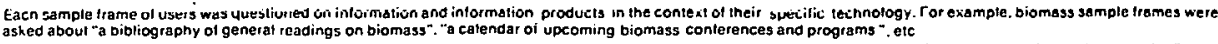

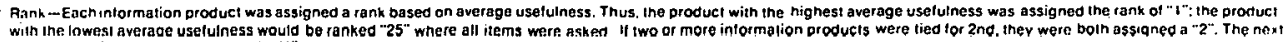

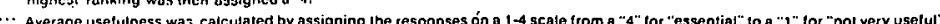

Figure 3-10. Usefulness of Selected Information Items: All Researchers 
Table 3-5. 8UMMAFY: RANES OP TOP-RATBD ENFORMATION TTBMS: BIOMASS RESBABCHEFS AND ALL RESBARCHBRS ${ }^{a}$

\begin{tabular}{|c|c|c|c|c|c|c|c|c|c|c|}
\hline \multirow[b]{2}{*}{ Information Item } & \multicolumn{4}{|l|}{. } & \multicolumn{6}{|c|}{ Biomass Researcher Group } \\
\hline & $\begin{array}{l}\text { Fed } \\
\text { Funded } \\
\text { ?\&C }\end{array}$ & $\begin{array}{c}\text { Nonfed } \\
\text { Funded } \\
\text { P\&C }\end{array}$ & $\begin{array}{c}\text { Fed. } \\
\text { Funded } \\
\text { Conver- } \\
\text { sion }\end{array}$ & $\begin{array}{l}\text { Nonfed. } \\
\text { Funded } \\
\text { Conver- } \\
\text { sion }\end{array}$ & $\begin{array}{l}\text { Total } \\
\text { P\&C }\end{array}$ & $\begin{array}{l}\text { Total } \\
\text { Conver- } \\
\text { sion }\end{array}$ & $\begin{array}{l}\text { Total } \\
\text { Feć. } \\
\text { Funded }\end{array}$ & $\begin{array}{l}\text { Total } \\
\text { Nonfed. } \\
\text { Funded }\end{array}$ & $\begin{array}{l}\text { Total } \\
\text { Biomess }\end{array}$ & $\begin{array}{c}\text { All } \\
\text { Researchers }\end{array}$ \\
\hline The State of the Art & 1 & 5 & 1 & 4 & 3 & 2 & 1 & 5 & 1 & 2 \\
\hline Research in Progress & 5 & 1. & 3 & 7 & 2 & 5 & 3 & 1 & 2 & 1 \\
\hline $\begin{array}{l}\text { Systems Installation/ } \\
\text { Operation Costs }\end{array}$ & 11 & 6 & 3 & 1 & 8 & 1 & $7-$ & 1 & 5 & 4 \\
\hline Systems Cost/Performance & 8 & 6 & g & 1 & 6 & 2 & 7 & 1 & 5 & 3 \\
\hline $\begin{array}{l}\text { Institutional, Social, } \\
\text { Environmental, or } \\
\text { Legal Aspects }\end{array}$ & 5 & 9. & 12 & 13 & 6 & 12 & 7 & 12 & 9 & 18 \\
\hline Expected Developments & 2 & 3 & 6 & 9 & 4 & 8 & 3 & 6 & 7 & $\mathfrak{j}$ \\
\hline Information Sources & 2 & 1 & 1 & 13 & 1 & 10 & 2 & 6 & 3 & 6 \\
\hline Technical Experts & 2 & 3 & 6 & 4 & 4 & 5 & 3 & 4 & 3 & 11 \\
\hline $\begin{array}{l}\text { Technical Descriptions } \\
\text { of Systems }\end{array}$ & 5 & 11 & 6 & 4 & 8 & 5 & 6 & 8 & 8 & 8 \\
\hline $\begin{array}{l}\text { Manual Analytical Tools } \\
\text { for Systems Design }\end{array}$ & 20 & 15 & 3 & 3 & 16 & 2 & 11 & 8 & 10 & 9 \\
\hline
\end{tabular}

IIncludes all of those items ranked Ist through sth by any Biomass Researcher group or combination of groups or by All Researchers. 
The Nonfed Researchers were more interested in cost-related information than the Fed Researchers. Total Biomass Researchers gave higher ratings to "institutional ... aspects" and to "lists of technical experts" than did All Researchers. In fact, the four Biomass Researcher groups were among the very few groups of the 86 studied that were interested in "lists of technical experts."

In examining the items receiving the lowest ratings, none of the following items were ranked in the top 14 by any of the four groups:

- Local building codes or other regulations;

- Marketing statistics and sales projections; and

- Standards, specifications, or certification programs.

Building codes, regulations, and standards are of ten not particularly relevant for biomass, as most biomass growth and collection processes take place in rural areas and do not involve any out-of-the-ordinary structures. Marketing information generally tended to be low-rated by All Researchers.

For Total Biomass Researchers, statistical tests indicated that the differences between ratings for the six highest-rated items (listed above) and the eight lowest-rated ones (the items ranked 17 th through 24 th in Fig. $3-9)$ were all statistically $(P<0.05)$ significant.

It should be noted, however, that these lower-rated items were not necessarily of no worth to the Biomass Researchers. For example, 10 of the 36 (28\%) Biomass Researchers thought "standards" were either "essential" or "very useful." Thus, these information categories/products could be useful to some Biomass Researchers, but were of a lower relative priority to the entire group.

Statistical Comparisons. Statistical tests were used to determine whether any of the Biomass Researcher groups rated any of these information items significantly higher (or lower) than they were rated by any of the other three groups or by Total Biomass Researchers or All Researchers. Some groups, however, tended to give higher scores in general than did other groups. To compensate for this effect, these statistical tests compared the "relative rating" given by one group to the relative rating given by the other groups. The procedure for calculating the relative ratings is described in Appendix E. Fed P\&C Researchers gave the highest overall ratings of the four groups, 2.42 when averaged across all questions. Nonfed P\&C Researchers had an overall average of 2.16 (in the lowest 6 of the 86 groups studied); Fed Conv Researchers, 2.34; and Nonfed Conv Researchers, 2.23 .

In comparing the combined results of both groups of $\mathrm{P} \& \mathrm{C}$ Researchers to those for Conv Researchers (both groups combined), only two items showed statistically significant differences in ratings. P\&C Researchers rated "lists of sources" significantly $(P<0.05)$ higher than did the Conv Researchers (and than did All Researchers), while the Conv Researchers rated "manual methods" significantly $(P<0.05)$ higher than did either their P\&C counterparts or All Researchers.

Comparisons between Total Fed Researchers and Total Nonfed Researchers indicated no significant differences in ratings by the two groups.

In comparing ratings between Total Biomass Rescarchers and $\Lambda$ ll Researchers, a number of items showed significant differences in ratings. Total Biomass Researchers rated as 
significantly $(P<0.05)$ higher not only "lists of sources," but also: "a nontechnical description," "lists of technical experts," "educational institutions," and "institutional, social, environmental, and legal aspects." They gave significantly $(P<0.05)$ lower ratings than did All Researchers to: "local building codes," "standards, specifications," "marketing statistics and sales projections," and "climatalogical data."

\subsection{ACQUISITION OF INFORMATION BY-RESPONDENTS}

\subsubsection{Use of Selected Information Sources}

Biomass Researchers were asked which of 20 different potential sources of solar information they had used in the past few years. For this question the respondents were not asked if they had obtained information on biomass energy, but instead were asked if they had obtained any solar information from each specific source. Thus, the question sought to determine which information sources were the most familiar to respondents. The results are shown in Table 3-6.

The information sources mentioned most of ten by Total Biomass Researchers were:

- An organizational library or a local library;

- Workshops, conferences, or training sessions;

- The Bio-Energy Council;

- The Government Printing Office (GPO);

- USDA; and

- Directly from the U.S. Department of Energy (DOE).

The information sour ces mentioned least of ten were:

- Solar Energy Industries Association (SEIA),

- National Solar Heating and Cooling Information Center (NSHCIC),

- International Solar Energy Society (ISES),

- Smithsonian Science Information Exchange (SSIE),

- Regional Solar Energy Centers (RSECs), and

- Technical Information Center (TIC).

Compared to All Researchers the Total Biomass Researchers were much less likely to use ISES, TIC, DOE, and NSHCIC, but were more likely to use USDA and the Bio-Energy Council.

Of the four groups of Biomass Researchers, the Nonfed Conv Researchers were the least familiar with the information sources listed; 12 of the 20 sources had been used by 3 or fewer respondents. The sources for which this familiarity was high, compared to the other three groups, were GPO, NTIS, and "a. public utility company." The Fed Conv Researchers were the most likely to have used a variety of sources. 
Table 3-6. SOURCES USBD TO OBTAIN SOLAR INPORMATION: BIOMASS RESBARCHERS

\begin{tabular}{|c|c|c|c|c|c|c|c|c|c|c|}
\hline \multirow{3}{*}{ Information Sources } & \multicolumn{10}{|c|}{ Biomass Researcher Group } \\
\hline & $\begin{array}{l}\text { Fed. } \\
\text { Funded } \\
\text { P\&C }\end{array}$ & $\begin{array}{l}\text { Nonfed. } \\
\text { Punded } \\
\text { P\&C }\end{array}$ & $\begin{array}{l}\text { Ped. } \\
\text { Funded } \\
\text { Conver- } \\
\text { sion }\end{array}$ & $\begin{array}{l}\text { Nonfed. } \\
\text { Punded } \\
\text { Conver- } \\
\text { sion }\end{array}$ & $\begin{array}{l}\text { Total } \\
\text { P\&C }\end{array}$ & $\begin{array}{l}\text { Total } \\
\text { Conver- } \\
\text { sion }\end{array}$ & $\begin{array}{l}\text { Total } \\
\text { Fed. } \\
\text { Funded }\end{array}$ & $\begin{array}{l}\text { Total } \\
\text { Nonfed. } \\
\text { Funded }\end{array}$ & $\begin{array}{c}\text { Total } \\
\text { Biomass }\end{array}$ & $\begin{array}{c}\text { All } \\
\text { Researchers }\end{array}$ \\
\hline & Percent $^{\mathrm{A}}$ & Percent & Percent & Percent & Percent & Percent & Percent & Percent & Percent & Percent \\
\hline \multicolumn{11}{|l|}{ Private Solar-Involved Organizations } \\
\hline $\begin{array}{l}\text { Private solar energy or environmental } \\
\text { organizations } \\
\text { International Solar Energy Society (ISES) }\end{array}$ & 63 & 67 & 70 & 33 & $65^{\circ}$ & 53 & 67 & 50 & 58 & 53 \\
\hline $\begin{array}{l}\text { (including publications) } \\
\text { solar Energy Industries Association (SEIA) }\end{array}$ & 25 & 44 & 20 & $\mathbf{0}$ & 35 & 11 & 22 & 22 & 22 & 48 \\
\hline $\begin{array}{l}\text { (including publications) } \\
\text { Contacts With Professionsls }\end{array}$ & 0 & 22 & 20 & $\mathbf{0}$ & 12 & 11 & 11 & 11 & 11. & 33 \\
\hline $\begin{array}{l}\text { Solar installer, builder, Jesigner, } \\
\text { or manufacturer } \\
\text { Workshops, conferences, or training }\end{array}$ & 50 & 56 & 60 & 22 & 53 & 42 & 56 & 39 & 47 & 65 \\
\hline $\begin{array}{l}\text { sessions } \\
\text { Information Services }\end{array}$ & 75 & 67 & 80 & 67 & 71 & 74 & 78 & 67 & 72 & 88 \\
\hline $\begin{array}{l}\text { Respondent's organizational library } \\
\text { or local library } \\
\text { A commercial data base } \\
\text { Smithsonian Science Information }\end{array}$ & $\begin{array}{l}88 \\
25\end{array}$ & $\begin{array}{l}89 \\
33\end{array}$ & $\begin{array}{r}100 \\
60\end{array}$ & $\begin{array}{r}63 \\
0\end{array}$ & $\begin{array}{l}88 \\
29\end{array}$ & $\begin{array}{l}83 . \\
32\end{array}$ & 94 & $\begin{array}{l}76 \\
17\end{array}$ & $\begin{array}{l}86 \\
31\end{array}$ & $\begin{array}{l}84 \\
38\end{array}$ \\
\hline $\begin{array}{l}\text { Exchange } \\
\text { A Federal Library or Information }\end{array}$ & 38 & 22 & 30 & $\mathbf{0}$ & 29 & 16 & 33 & 11 & 22 & 17 \\
\hline $\begin{array}{l}\text { Center } \\
\text { Goivernment Printing O:fice (GPO) } \\
\text { National Technical Info:mation }\end{array}$ & $\begin{array}{l}63 \\
63\end{array}$ & $\begin{array}{l}67 \\
56\end{array}$ & $\begin{array}{l}70 \\
70\end{array}$ & $\begin{array}{l}33 \\
78\end{array}$ & $\begin{array}{l}65 \\
59\end{array}$ & $\begin{array}{l}53 \\
74\end{array}$ & $\begin{array}{l}67 \\
67\end{array}$ & $\begin{array}{l}50 \\
67\end{array}$ & $\begin{array}{l}58 \\
67\end{array}$ & $\begin{array}{l}54 \\
74\end{array}$ \\
\hline $\begin{array}{l}\text { Service (NTIS) } \\
\text { Technical Information Center (TIC) }\end{array}$ & $\begin{array}{l}38 \\
50\end{array}$ & $\begin{array}{l}56 \\
33\end{array}$ & $\begin{array}{l}70 \\
20\end{array}$ & $\begin{array}{l}67 \\
11\end{array}$ & $\begin{array}{l}47 \\
41\end{array}$ & $\begin{array}{l}68 \\
16\end{array}$ & $\begin{array}{l}56 \\
33\end{array}$ & $\begin{array}{l}61 \\
22\end{array}$ & $\begin{array}{l}58 \\
28\end{array}$ & $\begin{array}{l}64 \\
40\end{array}$ \\
\hline
\end{tabular}

${ }^{\text {apeent }}$ is the percentage of respondents who used the source to obtain any solar information in the past few years.

$\mathrm{b}_{n}()^{n}$ means the question was not asked of all of the groups in the particular set of respondents. For example, "(44)" means that $44 \%$ of those who were asked had used that source. In no case were lewer than nine respondnets asked. 
TEble 2-6. SOURCES USBD TO OBTAN SOLAR INFORMATION: BIOMASS RESBARCHRFS (Concl ¿ded)

\begin{tabular}{|c|c|c|c|c|c|c|c|c|c|c|}
\hline \multirow{3}{*}{ Information Sources } & \multicolumn{10}{|c|}{ Biomass Researcher Group } \\
\hline & $\begin{array}{l}\text { Ped: } \\
\text { Funde\} } \\
\text { P\&C }\end{array}$ & $\begin{array}{l}\text { Nonfed. } \\
\text { Punded } \\
\text { P\&C }\end{array}$ & $\begin{array}{l}\text { Fed. } \\
\text { Funded } \\
\text { Conver- } \\
\text { sion }\end{array}$ & $\begin{array}{l}\text { Nonfed. } \\
\text { Punded } \\
\text { Conver- } \\
\text { sion }\end{array}$ & $\begin{array}{l}\text { Total } \\
\text { P\&CC }\end{array}$ & $\begin{array}{c}\text { Total } \\
\text { Conver- } \\
\text { sion }\end{array}$ & $\begin{array}{l}\text { Totall } \\
\text { Pec. } \\
\text { Funced }\end{array}$ & $\begin{array}{c}\text { Total } \\
\text { Nonfed. } \\
\text { Funded }\end{array}$ & $\begin{array}{c}\text { Total } \\
\text { Bic-mass }\end{array}$ & $\stackrel{\text { All }}{\text { Researchers }}$ \\
\hline & Percent ${ }^{\mathrm{a}}$ & Percent & Percent & Percent & Percent & Percent & Percernt & Percent & Percent & Percent \\
\hline $\begin{array}{l}\text { Government Solar-Irvolved Organizations } \\
\text { Directly from the U.S. Department of } \\
\text { Energy } \\
\text { National Solar Heating \& Cooling }\end{array}$ & 63 & 56 & 70 & 56 & 59 & 63 & 67 & 56 & 31 & 80 \\
\hline $\begin{array}{l}\text { Information Center } \\
\text { Regional Solar Energy Centers } \\
\text { State Energy or Solar Offices } \\
\text { Other }\end{array}$ & $\begin{array}{l}13 \\
38 \\
38\end{array}$ & $\begin{array}{l}22 \\
22 \\
44\end{array}$ & $\begin{array}{l}30 \\
30 \\
60\end{array}$ & $\begin{array}{r}0 \\
0 \\
22\end{array}$ & $\begin{array}{r}18 \\
\cdot 29 \\
41\end{array}$ & $\begin{array}{l}16 \\
16 \\
-42\end{array}$ & $\begin{array}{l}22 \\
33 \\
50\end{array}$ & $\begin{array}{l}11 \\
11 \\
33\end{array}$ & $\begin{array}{l}17 \\
22 \\
12\end{array}$ & $\begin{array}{l}29 \\
23 \\
48\end{array}$ \\
\hline $\begin{array}{l}\text { Some other state or local government } \\
\text { office or publicarion } \\
\text { A public utility company } \\
\text { U.S. Department of Agriculture, }\end{array}$ & $\begin{array}{l}25 \\
50\end{array}$ & $\begin{array}{l}33 \\
5 \hat{3}\end{array}$ & $\begin{array}{l}50 \\
40\end{array}$ & $\begin{array}{l}13 \\
67\end{array}$ & $\begin{array}{l}29 \\
53\end{array}$ & $\begin{array}{l}33 \\
53\end{array}$ & $\begin{array}{l}39 \\
44\end{array}$ & $\begin{array}{l}24 \\
61\end{array}$ & $\begin{array}{l}31 \\
53\end{array}$ & $\begin{array}{l}28 \\
51\end{array}$ \\
\hline $\begin{array}{l}\text { including Extension and Forestry } \\
\text { Bio-Energy Council }\end{array}$ & $\begin{array}{l}88 \\
75\end{array}$ & $\begin{array}{l}67 \\
56\end{array}$ & $\begin{array}{r}60 \\
80\end{array}$ & $\begin{array}{l}56 \\
78\end{array}$ & $\begin{array}{l}76 \\
65\end{array}$ & $\begin{array}{l}58 \\
79\end{array}$ & $\begin{array}{l}72 \\
78\end{array}$ & $\begin{array}{l}61 \\
67\end{array}$ & $\begin{array}{l}67 \\
? 2\end{array}$ & $\begin{array}{l}(67)^{b} \\
(72)\end{array}$ \\
\hline
\end{tabular}

Bercent is the percentage of respondents who used the source to obtain gny solar information in the past few years.

bur()" means the question was not asked of all of the grcups in the particular set of respondents. For example, "(44)" means that 44\% cf those who were asked had used that source. In no case were fewer than nine respor.dents asked. 
P\&C Researchers appeared to use USDA and TIC more than the Conv Researchers did, but used NTIS less. Total Fed Researchers appeared to use the SSIE and the RSECs more than the Total Nonfed Researchers did, but used "a public utility company" less.

\subsubsection{Membership in Solar-Interested Organizations}

Seven of the 8 Fed P\&C Researchers interviewed were members of a professional, technical, or other organization with an interest in solar energy (not necessarily biomass), as were 5 of the 9 Nonfed P\&C Researchers, 7 of the 10 Fed Conv Researchers, and 4 of the 9 Nonfed Conv Researchers.

The organizations mentioned and the number belonging to each are displayed in Table 3-7. One Fed P\&C Researcher also mentioned belonging to "SAMPE," one Nonfed P\&C Researcher to "ACP,"and one Fed Conv Researcher to "Microbiology." These were organizations which the authors could not verify.

For Total Biomass Researchers, five organizations were the most popular: American Association for the Advancement of Science, American Chemical Society, American Public Works Association, American Society of Mechanical Engineers; and National Society of Professional Engineers. All but one of the organizations named was a professional organization and not solar specific.

\subsubsection{Exposure to Publications on Solar Fnergy}

In each of the four groups all respondents had read publications during the past 6 months that included information on biomass energy. These publications and the number of respondents mentioning each are shown in Table 3-8. The extensive list of publications indicates that biomass energy information appeared in a wide variety of professional and technical publications. DOE was the most frequently mentioned as a publisher. Specific publications mentioned by 3 or more Biomass Researchers were: Biomass Digest, Fortune, and Biotechnology and Bioengineering. For the most part there were few publications mentioned by more than 1 respondent.

\subsubsection{Use of Spectal Acquisilion Methods}

The respondents were asked whether they had obtained any information (not just biomass or solar energy) in the past year by computer terminal, by Computer Output Microform (COM), or by other microform (e.g., microfiche, microfilm sheets or rolls). Total Biomass Researchers were more likely than were All Researchers to have used computer terminals and COM, but were less likely to have used other microforms. Total P\&C Researchers were more likely than Total Conv Researchers to have used all three methods. Similarly, Total Fed Researchers were more likely than were Total Nonfed Researchers to have used all three forms (see Table 3-9). Use of COM by each group was generally lower than was use of computer terminals or other microforms. 
Table 3-7. MEMBERSHIP IN SOLAR-INTERESTED ORGANIZATIONS: BIOMASS RESEARCHERS

\begin{tabular}{cccc} 
& \multicolumn{3}{c}{ Researcher Group $^{\text {a }}$} \\
\cline { 2 - 4 } Organization & Fed. & $\begin{array}{c}\text { Non- } \\
\text { fed. Fed. }\end{array}$ Non- \\
& Funded & Funded Funded fed. & Funded \\
& P\&C & $\begin{array}{c}\text { F\&C } \\
\text { Conv. }\end{array}$ & Conv.
\end{tabular}

American Association for the Advancement of Science

American Chemical Society

American Institute of Aeronautics and Astronautics

American Institute of Biological Sciences

American Institute of Chemical Engineers

American Physical Society

American Public Works Association

American Science Engineering

American Society for.Photobiology

American Society for Microbiology

American Society of Agricultural Engineers

American Society of Animal Protection

American Society of Biological Chemists

American Society of Civil Engineers

American Society of Heating,

Refrigerating and Air Conditioning Engineers

American Society of Mechanical Engineers

American Society of Plant Physiologists

Asssociation for Computing Machinery

Bio-Energy Council

Biophysical Society

Ecological Society of America

International Solar Energy Society

London Chemical Society

National Society of Professional Engineers

New Jersey Computer Institute

Ohio Academy of Science

Society for Industrial and Applied

Mechanics

Society of American Foresters

Solar Research Society (Jackson, MS)

Water Pollution Control Federation

None ("No," or "don't know")

1

$\begin{array}{lllll}1 & - & 2 & 1 & 4\end{array}$

1

$1 \quad-$

$-\quad-$

$=$

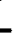

$$
\overline{-}
$$$$
\overline{1}
$$$$
-
$$$$
\text { - }
$$$$
\text { - }
$$$$
\overline{1}
$$

1

1

$-$

$-1$

- 1

-

- 1

$-\quad-$

$\frac{-}{1}$
$\frac{1}{1}$
$\frac{1}{1}$
$\frac{1}{-}$$$
1 \quad-
$$

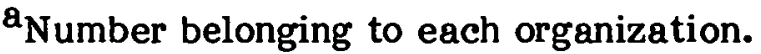


Table 3-8. PUBLICATIONS READ WHICH INCLUDED INFORMATION ON SOLAR ENERGY: BIOMASS RESEARCHERS

\begin{tabular}{|c|c|c|c|c|c|}
\hline \multirow[b]{2}{*}{ Publication } & \multicolumn{4}{|c|}{ Researcher Group $^{\mathbf{a}}$} & \multirow[b]{2}{*}{ Tota] } \\
\hline & $\begin{array}{c}\text { Fed. } \\
\text { Funded } \\
\text { P\&C }\end{array}$ & $\begin{array}{c}\text { Non- } \\
\text { fed. } \\
\text { Funded } \\
\text { P\&C }\end{array}$ & $\begin{array}{c}\text { Fed. } \\
\text { Funded } \\
\text { Conv. }\end{array}$ & $\begin{array}{c}\text { Non- } \\
\text { fed. } \\
\text { Funded } \\
\text { Conv. }\end{array}$ & \\
\hline Aero Sun Times & - & - & - & 1 & 1 \\
\hline Agricultural Engineering & - & 1 & - & - & 1 \\
\hline Applied and Environmental Microbiology & 1 & - & - & - & 1 \\
\hline Area Development Magazine & - & - & - & 1 & 1 \\
\hline Army programs publications & - & - & 1 & - & 1 \\
\hline Australian Journal of Plant Physiology & 1 & - & - & - & 1 \\
\hline Bio-Energy Directory & - & 1 & 1 & - & 2 \\
\hline \multicolumn{6}{|l|}{ Biological solar energy conservation } \\
\hline publications & 1 & - & 一 & - & 1 \\
\hline Biomass Digest & 1 & 1 & 1 & - & 3 \\
\hline \multicolumn{6}{|l|}{ Biomass Energy Institute Newsletter } \\
\hline (Bio-Joule Newsletter) & 一 & 一 & 1 & - & -1 \\
\hline Biotechnology and Bioengineering & - & 1 & 1 & 1 & 3 \\
\hline \multicolumn{6}{|l|}{$\frac{\text { Biotechnology and Bioengineering Symposia }}{\text { (4 of } 12 \text { published specifically on }}$} \\
\hline biomass conversion) & - & - & - & 1 & $\cdot 1$ \\
\hline Burlington Electric Consulting Reports & 1 & 一 & - & - & 1 \\
\hline$\overline{C A S C A D E}$ & - & - & - & 1 & 1 \\
\hline Chemical Engineering & - & - & - & 1 & 1 \\
\hline Cliff Finney magazine article & - & - & 1 & - & 1 \\
\hline Combustion Science and Technology & - & - & 1 & 一 & 1 \\
\hline Compost Journal & - & 1 & - & 一 & 1 \\
\hline \multicolumn{6}{|l|}{ DOE reports (unspecified and weekly } \\
\hline information publication) & 2 & 1 & 1 & 3 & 7 \\
\hline \multicolumn{6}{|l|}{ Electric Power Research Institute } \\
\hline $\begin{array}{l}\text { survey June 1978) } \\
\text { Energy }\end{array}$ & 1 & $\overline{3}$ & 一 & - & 1 \\
\hline$\frac{\text { Energy }}{\text { Energy Insider }}$ & 一 & 1 & - & - & 1 \\
\hline Energy Insider & - & - & 1 & - & 1 \\
\hline Energy Users Report & - & - & 1 & - & 1 \\
\hline$\overline{\text { Environmental Protection Agency reports }}$ & - & - & 1 & - & 1 \\
\hline Forest Products Journal & - & - & - & 1 & 1 \\
\hline Fortune & 1 & - & - & 2 & 3 \\
\hline$\overline{\text { Gasohol USA }}$ & - & 1 & 一 & - & 1 \\
\hline Georgia Institute of 'l'echnology publications & - & - & 1 & - & 1 \\
\hline Ghosh and Klass journal article & - & - & 1 & - & 1 \\
\hline Government reports (unspecified) & 1 & - & - & - & 1 \\
\hline Journal of Energy & - & 1 & - & - & 1 \\
\hline Journal of Environmental Quality & - & 1 & - & - & 1 \\
\hline Journal of Fuel and Heat Technology (UK) & - & - & 1 & - & 1 \\
\hline "Journul of Watẹ and Waste" (WPCF) & - & 1 & $\rightarrow \infty$ & - & 1 \\
\hline "Municipal Solid Waste Journal" & - & - & - & 2 & 2 \\
\hline
\end{tabular}


Table 3-8. PUBLICATIONS READ WHICH INCLUDED INPORMATION ON SOLAR ENERGY: BIOMASS RESEARCHERS (Concluded)

\begin{tabular}{|c|c|c|c|c|c|}
\hline \multirow[b]{2}{*}{ Publioation } & \multicolumn{4}{|c|}{ Researcher Group ${ }^{2}$} & \multirow[b]{2}{*}{ Total } \\
\hline & $\begin{array}{l}\text { Fed. } \\
\text { Funded } \\
\text { P\&C }\end{array}$ & $\begin{array}{l}\text { Non- } \\
\text { fed. } \\
\text { Funded } \\
\text { P\&C }\end{array}$ & $\begin{array}{c}\text { Fed. } \\
\text { Funded } \\
\text { Conv. }\end{array}$ & $\begin{array}{c}\text { Non- } \\
\text { fed. } \\
\text { Funded } \\
\text { Conv. }\end{array}$ & \\
\hline \multicolumn{6}{|c|}{$\begin{array}{l}\text { National Academy of Sciences publications } \\
\text { (including Biomass, A Self-Replacement }\end{array}$} \\
\hline Energy, September 1979) & 1 & - & - & - & 1 \\
\hline NĀSA P̈ubliculions & - & - & 1 & - & $\mathbf{I}$ \\
\hline Nhtinngl Civir: R.eview & - & - & - & 1 & 1 \\
\hline \multicolumn{6}{|c|}{ National Parks and Conservation Magazine } \\
\hline (Tlie Enviruniliental Juurial) & - & - & - & 1 & 1 \\
\hline National Library Technical Reports & - & 1 & - & - & 1 \\
\hline NTIS progress reports & $\dot{-}$ & - & 1 & - & 1 \\
\hline "National Waste News" magazine & - & - & 一 & 1 & 1 \\
\hline Newsweek & 1 & - & - & 一 & 1 \\
\hline Parson Engineering Company reports & - & - & - & 1 & 1 \\
\hline Plant Management and Engineering & - & 1 & - & - & 1 \\
\hline Plant Physiology & 1 & - & - & - & 1 \\
\hline Rain & - & - & - & 1 & 1 \\
\hline$\overline{\text { Research journal articles }}$ & - & - & 1 & - & 1 \\
\hline Science & 1 & 1 & - & - & 2 \\
\hline Solar Energy Intelligence Report & - & - & 1 & - & 1 \\
\hline Solid Waste Management & - & - & 1 & 1 & 2 \\
\hline Status of Alcohol Fuels (DOE) & - & - & - & $\mathrm{l}$ & 1 \\
\hline I'echnical and trade journals & 2 & 1 & - & 1 & 4 \\
\hline "Tilth Magazine" & - & - & $=$ & 1 & 1 \\
\hline Time & 1 & - & - & - & 1 \\
\hline Waste Age & 一 & - & - & 1 & 1 \\
\hline Wood Energy Institute reports & 1 & - & - & - & 1 \\
\hline
\end{tabular}

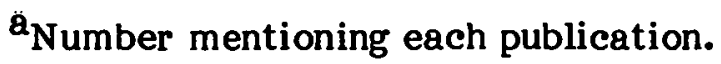


Table 3-9. USE OF SPECIAL ACQUISIION METHODS: BIOMASS RESEARCHERS

\begin{tabular}{|c|c|c|c|c|c|c|c|c|}
\hline \multirow{3}{*}{$\begin{array}{c}\text { Biomass } \\
\text { Researchers } \\
\text { Group }\end{array}$} & \multicolumn{6}{|c|}{ Acquisition Method } & & \\
\hline & \multirow{2}{*}{\multicolumn{2}{|c|}{$\begin{array}{l}\text { Computer } \\
\text { Terminals } \\
\text { No. Percent }\end{array}$}} & \multicolumn{2}{|c|}{ COM } & \multicolumn{2}{|c|}{$\begin{array}{l}\text { Other } \\
\text { Microforms }\end{array}$} & \multicolumn{2}{|c|}{$\begin{array}{c}\text { Total } \\
\text { Respondents }\end{array}$} \\
\hline & & & & ercent & & ercent & & ?ercent \\
\hline $\begin{array}{l}\text { Federally Funded P\&C } \\
\text { Nonfederally Funded P\&C } \\
\text { Federally Funded Conv } \\
\text { Nonfederally Funded Conv }\end{array}$ & $\begin{array}{l}4 \\
6 \\
6 \\
0\end{array}$ & $\begin{array}{r}50 \\
\therefore \quad 67 \\
60 \\
0\end{array}$ & $\begin{array}{l}2 \\
1 \\
1 \\
0\end{array}$ & $\begin{array}{r}25 \\
10 \\
11 \\
0\end{array}$ & $\begin{array}{l}2 \\
5 \\
5 \\
1\end{array}$ & $\begin{array}{l}25 \\
56 \\
50 \\
11\end{array}$ & $\begin{array}{r}8 \\
9 \\
10 \\
9\end{array}$ & $\begin{array}{l}100 \\
100 \\
100 \\
100\end{array}$ \\
\hline $\begin{array}{l}\text { Total P\&C } \\
\text { Total Conversion }\end{array}$ & $\begin{array}{r}10 \\
6\end{array}$ & $\begin{array}{l}59 \\
32\end{array}$ & $\begin{array}{l}3 \\
1\end{array}$ & $\begin{array}{r}18 \\
5\end{array}$ & $\begin{array}{l}7 \\
6\end{array}$ & $\begin{array}{l}41 \\
32\end{array}$ & $\begin{array}{l}17 \\
19\end{array}$ & $\begin{array}{l}100 \\
100\end{array}$ \\
\hline $\begin{array}{l}\text { Total Federally Funded } \\
\text { Total Nonfederally Funded }\end{array}$ & $\begin{array}{r}10 \\
6\end{array}$ & $\begin{array}{l}56 \\
33\end{array}$ & $\begin{array}{l}3 \\
1\end{array}$ & $\begin{array}{r}17 \\
6\end{array}$ & $\begin{array}{l}7 \\
6\end{array}$ & $\begin{array}{l}39 \\
33\end{array}$ & $\begin{array}{l}18 \\
18\end{array}$ & $\begin{array}{l}100 \\
100\end{array}$ \\
\hline $\begin{array}{l}\text { Total Biomass Researchers } \\
\text { All Researchers }\end{array}$ & $\begin{array}{l}16 \\
62\end{array}$ & $\begin{array}{l}44 \\
34\end{array}$ & $\begin{array}{r}4 \\
16\end{array}$ & $\begin{array}{r}11 \\
9\end{array}$ & $\begin{array}{l}13 \\
72\end{array}$ & $\begin{array}{l}36 \\
40\end{array}$ & $\begin{array}{r}36 \\
181\end{array}$ & $\begin{array}{l}100 \\
100\end{array}$ \\
\hline
\end{tabular}

\subsection{SUMMARY AND COMMENTS}

Thirty-six biomass researchers were studied. They were divided into four groups based on funding source (federal or nonfederal) and whether their research projects were primarily concerned with the production and collection (P\&C) of biomass feedstock for conversion to energy, or the actual conversion processes themselves. After the respondents were interviewed, it was discovered that Biomass P\&C Researchers tended to be involved in both areas. The Biomass Conversion Researchers, however, were not involved in $\mathrm{P} \& \mathrm{C}$ (growth and harvesting).

The level of involvement of Biomass Researchers and their degree of informedness were slightly higher than those of All Researchers interviewed in this study, although educational levels were similiar. Areas of investigation in which Biomass Researchers were involved covered (1) a range of energy feedstocks: energy crops (forest, farm, and aquatic); farm and forest residues; urban wastes; and (2) a range of conversion interests: photosynthesis, alcohol fuels, production, incineration, gasification, feasibility studies, and plant construction.

Biomass Researchers attributed the greatest utility to information on:

- The state of the art in biomass energy systems,

- Biomass energy system research in progress,

- Lists of sources for information on biomass energy systems,

- Lists of technical experts in biomass energy,

- Costs of installing and operating a biomass energy system compared to a conventional system, and

- Costs and performance of biomass energy systems. 
Biomass Conversion Researchers also rated "manual methods for sizing and predicting performance or costs of biomass energy systems" highly, while Biomass Production and Collection Researchers rated "expected major developments in biomass during the next 10 years" very highly.

Biomass Researchers gave low ratings to "local building codes or other regulations affecting siting or installation of biomass energy systems"; "marketing statistics and sales projections for biomass energy systems"; and "standards, specifications, or certification programs for biomass energy systems."

Like most Researchers interviewed in this study, they rated research and cost information as important. Their high interest in both "lists of sources" and "lists of technical experts" suggests a pressing need for more information in the specific aspects of biomass energy that are within the scope of each researcher's particular area of investigation. Biomass Researchers were among the very few groups of the 86 studied that were interested in "lists of technical experts."

Biomass Researchers most often received solar information through "an organizational library or a local library"; "workshops, conferences, or training sessions"; the Bio-Energy Council; GPO; USDA; and "directly from DOE." Most of these Researchers were members of organizations that provided them with solar information. The most frequently-named organizations were the American Association for the Advancement of Science, American Chemical Society, American Public Works Association, American Society of Mechanical Engineers, and the National Society of Professional Engineers. Biomass Researchers were also fairly extensive readers. The published information they read was provided by a substantial range of scientific and technical journals, environmental and solar publications, popular literature, and technical reports. 


\section{SECTION 4.0}

\section{BIOMASS MANUFACTURER REPRESENTATVES}

\subsection{DESCRIPTION OF RESPONDENTS}

\subsubsection{Description of Sample}

This section describes the results of two telephone studies to determine the needs of representatives of manufacturers involved in the production of agricultural equipment, forest equipment, and biomass energy conversion equipment for information on biomass energy systems. Nine representatives of Biomass Production and Collection Equipment Manufacturers (manufacturers of agricultural and forestry equipment) and 9 representatives of Biomass Conversion Equipment Manufacturers were interviewed. In the following these two groups will be referred to as Biomass P\&C Manufacturers and Biomass Conv Manufacturers.

The sample frame for Biomass P\&C Manufacturers was constructed from the 1979 Directory of Suppliers, Manufacturers, Technical Consultants, Professional Engineers [4] (put out by the Forest Products Research Society) and the Solar Energy Information Data Bank (SEIDB) Manufacturers Data Base [5]. From the Forest Products Research Society source, companies were used that were listed in the section on "Fuel Preparation, Handling and Storage Systems, Suppliers and Manufacturers." Companies used from the Data Base included those Fuel Processing Manufacturers involved with pulverizers or harvesters. After all adjustments were made, 9 interview candidates were randomly selected from a sample frame of 49 agricultural or forest equipment manufacturer representatives.

The sample frame for Biomass Conv Manufacturers was also constructed from the Forest Products Research Society source [4] and the SEIDB Manufacturer's Data Base [5]. In the Forest Products Research Society source, companies used were listed in the section on "Combustion and Heat Recovery Systems Suppliers and Manufacturers." Companies used from the Data Base included those manufacturers involved in Energy Production and those Fuel Processing Manufacturers involved with hydrolysis, distillation, separators, or dryers. Manufacturers of fireplaces, fireplace accessories, or woodburning stoves only, were eliminated. Manufacturers of wood-fired boiler systems, fireplace water heaters, gasifiers, plant and waste conversion systems, wood burning furnaces, organic decomposition systems, digesters, and pyrolysis systems were included. Af ter all adjustments were made, 9 interview candidates were randomly selected from a sample frame of 102 conversion equipment manufacturer representatives.

Respondents. In making the telephone calls to contact the randomly selected interview candidates, it sometimes occurred that the person could not be reached. In this event another randomly selected name was substituted for the original name. When individuals were contacted, it was verified that the company they worked for really was a P\&C or a conversion equipment manufacturer (as appropriate) and that they would be needing information on biomass energy within the next year. If they were not both involved and needing information, they were asked if they could refer the interviewer to someone else in their organization who would be an appropriate respondent. If such a referral was made, a call was then made to this new candidate; if no intraorganizational referral was made, a new candidate was randomly selected from the sample frame. The results of this process may be seen in Table 4-1. 
Table 4-1. COMPLETION OF INTERVIEWS: BIOMASS MANUFACTURER REPRESENTATIVES

\begin{tabular}{|c|c|c|}
\hline \multirow{2}{*}{ Event } & \multicolumn{2}{|c|}{ Number of Candidates } \\
\hline & $\begin{array}{l}\text { Production \&. } \\
\text { Conllertion } \\
\text { Equipment }\end{array}$ & $\begin{array}{l}\text { Convoreion } \\
\text { Equipment }\end{array}$ \\
\hline Interview completed with sample frame candidate & 6 & 4 \\
\hline Interview completed with referral candidate & 3 & 5 \\
\hline Refusal or candidate termination & 2 & 2 \\
\hline $\begin{array}{l}\text { Contact attempted: could not reach candidate } \\
\text { within three âtempts or before interviowe }\end{array}$ & & \\
\hline were completed & 0 & U \\
\hline Subtotal & 11 & 11 \\
\hline $\begin{array}{l}\text { Contact attempted: invalid candidate (e.g., } \\
\text { inappropriate field of interest, no telephone) }\end{array}$ & 7 & 2 \\
\hline TOTAL & 18 & 13. \\
\hline $\begin{array}{l}\text { Sample frame error rate }{ }^{a} \text { (Percent) } \\
\text { Completion rate }^{b} \text { (Percent) }\end{array}$ & $\begin{array}{l}39 \\
82\end{array}$ & $\begin{array}{l}15 \\
82\end{array}$ \\
\hline
\end{tabular}

anvalid candidates divided by TOTAL

${ }^{\mathrm{b}}$ Completed interviews divided by Subtotal

Comparisons. For additional insight into the information needs and the information habits of these representatives of Biomass Manufacturers, results from this group are compared to the results from representatives of All (solar) Manufacturars. In pcrforming any statistical comparisons, the totals for the two groups of Biomass Manufacturers have been subtracted from the totals for All Manufacturers. The data for Biomass P\&C Manufacturers, Biomass Conv Manufacturers, and All Manufacturers can be found in Appendix F.

\subsubsection{Current Status of Respondents}

Role. Five of the 9 Biomass P\&C Manufacturers were manufacturing harvesting equipment. Other types of equipment manufartured by this group included municipal waste separators (2), energy storage equipment, pelletizers, hammer mills, grapple-skidders, feller-bunchers, pelletized industrial fuel, gas generators, rotary drum dryers, flash tube dryers, chippers, grinders, crushers, and shredders.

Products manufactured by the 9 Biomass Conv Manufacturers included: wood burning furnaces (3), wood-fired boiler systems (2), digesters (2), heat exchangers (2), hydronic heat reclaimers (2), fireplaces (2), thermal sensors, pyrolysis systems, and wood burning stoves.

Involvement. Seven of the 9 (78\%). representatives of Biomass P\&C Manufacturers and 8 of the 9 (89\%) Biomass Conv Manufacturers felt that they were "very involved" in biomass energy. A statistical comparison between the two Biomass Manufacturer groups 
and All Manufacturers (77 of the 96, or $80 \%$ "very involved") showed no significant differences in degree involved.

Informedness. In both groups of Biomass Manufacturers 6 of the 9 representatives (67\%) felt they were "very informed." A statistical comparison with All Manufacturers (72 of the 96 , or $75 \%$ "very informed") showed no significant differences in degree of informedness.

Need for Information. All respondents indicated they would need biomass energy information either on the job or outside the job during the next year. In both groups 8 of the 9 representatives of Biomass Manufacturers indicated they would need information on biomass on the job. Four of the 9 (44\%) Biomass P\&C Manufacturers and 3 of the 9 (33\%) Biomass Conv Manufacturers also indicated that they would need information on biomass outside the job. This did not differ significantly from All Manufacturers, in which 93 of the 96 (97\%) were interested in information on the job and 47 of the $96(49 \%)$ outside the job.

\subsubsection{Background of Respondents}

Four of the 9 representatives of Biomass P\&C Manufacturers held bachelor's degrees, one held an associate degree, and the remaining 4 were high school graduates. They had significantly $(P<0.05)$ fewer advanced degrees than did All Manufacturers $(30$ of the 96 , or 31\%). All 4 degrees were received in engineering, with specific fields mentioned including chemical, electrical, and mechanical engineering. All 4 received their most recent degree from 27 to 32 years ago.

The representatives of Biomass Conv Manufacturers had more formal education, with 6 of the 9 having bachelor's degrees and 2 having master's degrees ( 1 had some high school). Types of degrees received varied widely including: economics (2), mechanical engineering (2), forestry, architecture, fine arts, and liberal arts. Three received their most recent degree over 25 years ago, 3 from 10-20 years ago, and 2 within the past 10 years.

The degree of professional experience varied among the representatives of Biomass $\mathrm{P} \& \mathrm{C}$ Manufacturers, with 1 in his/her current profession for 2 or fewer years, one for 3-5 years, one for 6-10 years, and 6 for over 10 years. Collectively, this group had slightly more years of experience than did either Biomass Conv Manufacturers or Total Manufacturers. Three of the respondents described their current profession as engineers, 3 were in marketing, 2 in sales, and 1 did not answer. Five of the 9 specifically stated they were in management positions.

The degree of professional experience among representatives of Biomass Conv Manufacturers also varied, with 1 in the current profession for 2 or fewer years, 2 for 3-5 years, 2 for 6-10 years, and 4 for over 10 years. Three of the Biomass Conv Manufacturers described their current profession as managers, 1 was an entrepreneur, 1 a self-made engineer, and the remaining 4 mentioned business developer, mechanical engineer, forester, and manufacturer/distributor. 


\subsection{INFORMATION NEEDS OF RESPONDENTS}

\subsubsection{Technical Areas}

Representatives of Biomass Manufacturers were asked to choose those areas in which they were "particularly interested in obtaining information" from a list of selected technical areas of biomass energy (see Table 4-2). They were most interested in "commercial or industrial burning of biomass" (15 of the 18) and "burnable pellets, etc., from biomass" (14 of the 18). The Biomass Conv Manufacturers were not particularly interested (3 of the 9) in "liquid fuels from biomass materials."

Table 4-2. AREAS OF INTEREST: BIOMASS MANUFACTURER REPRESRNTATTVES

\begin{tabular}{|c|c|c|c|c|c|c|}
\hline \multirow{3}{*}{ Technical Area of Interest } & \multicolumn{6}{|c|}{ Manufacturer Group } \\
\hline & \multicolumn{2}{|c|}{$\begin{array}{l}\text { Production \& } \\
\text { Collection } \\
\text { Equipment }\end{array}$} & \multicolumn{2}{|c|}{$\begin{array}{l}\text { Conversion } \\
\text { Equipment }\end{array}$} & \multicolumn{2}{|c|}{ Total } \\
\hline & No. & Percent & No. & Percent & No. & Percent \\
\hline Total Respondents & 9 & 100 & 9 & 100 & 18 & 100 \\
\hline $\begin{array}{l}\text { Commercial or Industrial } \\
\text { Burning of Biomass }\end{array}$ & 7 & 78 & 8 & 89 & 15 & 83 \\
\hline $\begin{array}{l}\text { Burnable Pellets, etc., } \\
\text { from Biomass } \\
\text { Gases from Biomass Materials } \\
\text { Growth or Collection of }\end{array}$ & $\begin{array}{l}6 \\
7\end{array}$ & $\begin{array}{l}67 \\
78\end{array}$ & $\begin{array}{l}8 \\
6\end{array}$ & $\begin{array}{l}89 \\
67\end{array}$ & $\begin{array}{l}14 \\
13\end{array}$ & $\begin{array}{l}78 \\
72\end{array}$ \\
\hline $\begin{array}{l}\text { Biomass Materials } \\
\text { Residential Burning of Wood } \\
\text { Liquid Fuels from Biomass }\end{array}$ & $\begin{array}{l}5 \\
4\end{array}$ & $\begin{array}{l}56 \\
44\end{array}$ & $\begin{array}{l}6 \\
6\end{array}$ & $\begin{array}{l}67 \\
67\end{array}$ & $\begin{array}{l}11 \\
10\end{array}$ & $\begin{array}{l}61 \\
56\end{array}$ \\
\hline Materials & 6 & 67 & 3 & 33 & 9 & 50 \\
\hline
\end{tabular}

\subsubsection{Types of Information}

Representatives of Biomass Manufacturers were asked to name the information about biomass energy that was important for them to obtain. All 9 Biomass P\&C Manufacturers volunteered one or more items of information that they considered important. Information items receiving mentions as important included: information on quantities of biomass material (2), biomass equipment available (2), types of biomass materials available, a cost analysis of harvesting wood for energy, general economics information, the market potential for biomass, a list of industries that are potential users of biomass energy systems (including the systems they would use and to what extent), data on the locations of available biomass feedstocks, a description of how the conversion process works, technology updates, new developments in the decomposition of municipal wastes, lists of beneficial end products from biomass, better ways of separating biomass materials, composting of sewage sludge, methane gas generation, and data on mixing pellets with coal that would pass Environmental Protection Agency (EPA) standards. 
Information items considered important by Biomass Conv Manufacturers were similar to those mentioned by Biomass P\&C Manufacturers. The items named included: types of biomass materials/fuel available by geographic area (2), cost information, the marketing potential and degree of current use of the solar technology by geographic area, data on biomass conversion procedures, aquatic plants, types of material available from manufacturing, and pricing forecasts for oil during the next year.

Only 1 respondent in each of the Biomass Manufacturers groups volunteered that there was information they needed but were unable to get. The Biomass P\&C Manufacturer needed a list of sources for information and the Biomass Conv Manufacturer needed more data on conversion of waste.

Choice Between Specific Needs. A list of 11 types of biomass information products and 14 types of biomass information categories was read to each respondent. Each respondent described the usefulness of each particular item by assigning it a value of "essential," "very useful," "somewhat useful," or "not at all useful." The results are given in Figs. 4-1 and 4-2. For the purpose of comparison, the results for All Manufacturers (Fig. 4-3) are also included.

Representatives of Biomass P\&C Manufacturers selected "lists of sources for information" and descriptive information as most important. The six top-rated information categories/products were:

- Lists of sources for information;

- A technical description of how a particular system works;

- System diagrams or schematics;

- The state of the art;

- Expected major developments during the next 10 years; and

- Tax credits, grants, or other economic incentives.

Representatives of Biomass P\&C Manufacturers assigned the lowest relative ratings to:

- How to market and sell biomass systems;

- Biomass energy programs, research, industries, and markets outside the United States;

- Lists of local lenders, insurers, builders, engineers, installers, manufacturers, or distributors;

- Computer models for sizing and predicting performance or costs; and

- Institutional, social, environmental, and legal aspects.

Representatives of Biomass Conv Manufacturers selected "tax credits, grants" as the most important information category. The six top-rated information categories/products were:

- Tax credits, grants, or other economic incentives;

- The state of the art;

- Standards, specifications, or certification programs; 
Question \#8. I will read a list of potential information or information products on solar systems. For each, please tell me how useful that information would be to you. Would the following be: essential, very useful, somewhat useful, or not at all useful?

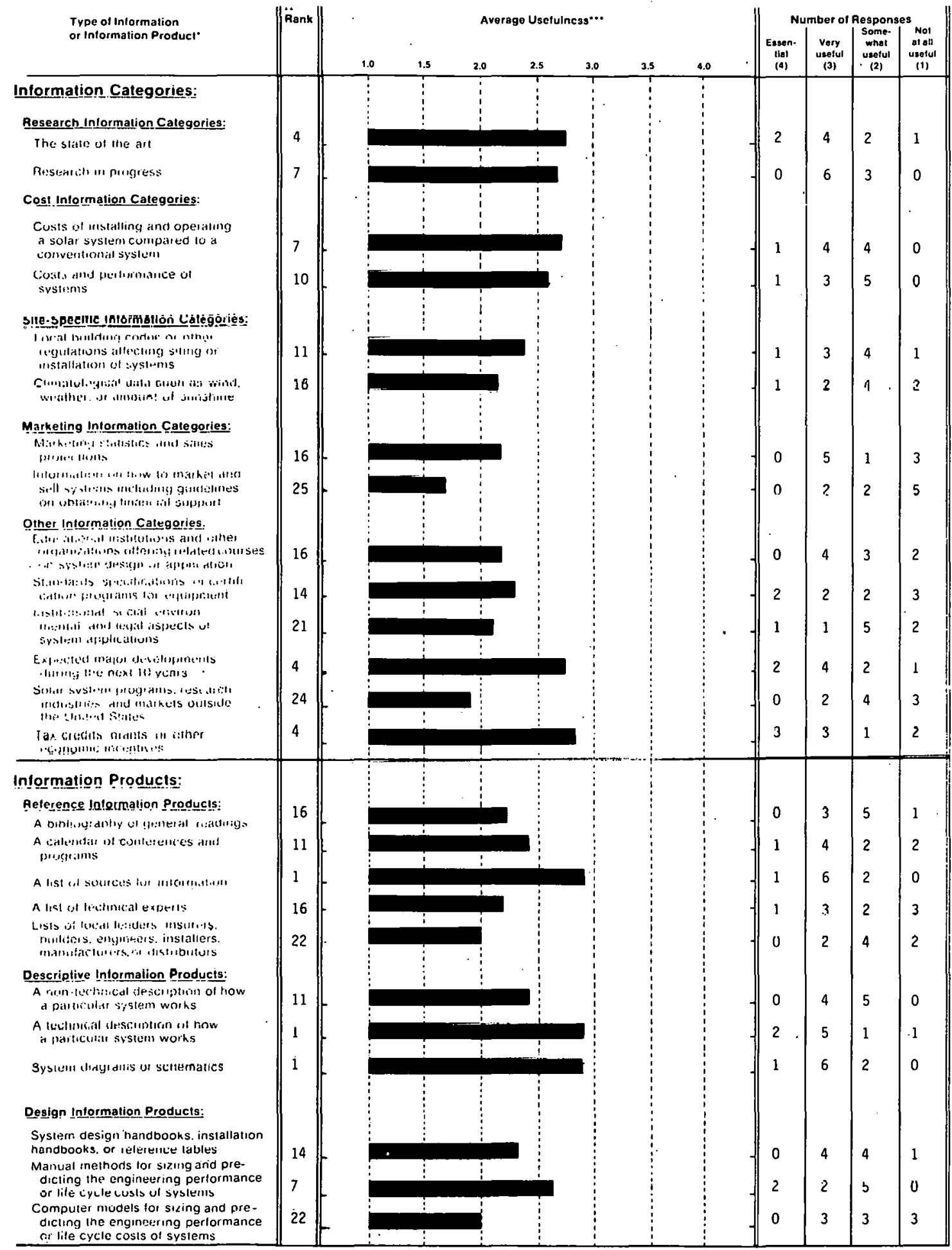

Each sample frame ol users was questioned on intormation and intormation products in the context of thetr specilic technology For example. biomass sample trames were

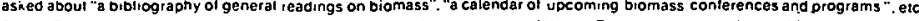

"Rank.- Eachinformation product was assigned a rank based on average usetuiness. Thus. The product with the highest average usetulness was assigned the rank of " $"$ ": the producl hignesi ranking was inen assigned a "4"

Average usetulness was calculated by assigning the responses on a 1.4 scale lrom a " " " tor "essential" to a "I" for "not very usetul".

Figure 4-1. Usefulness of Selected Information Items: Biomass Production and Collection Equipment Manufacturer Representatives 
Question \#8. I will read a list of potential information or information products on solar systems. For each; please tell me how useful that information would be to you. Would the following be: essential, very useful, somewhat useful, or nọt at all useful?

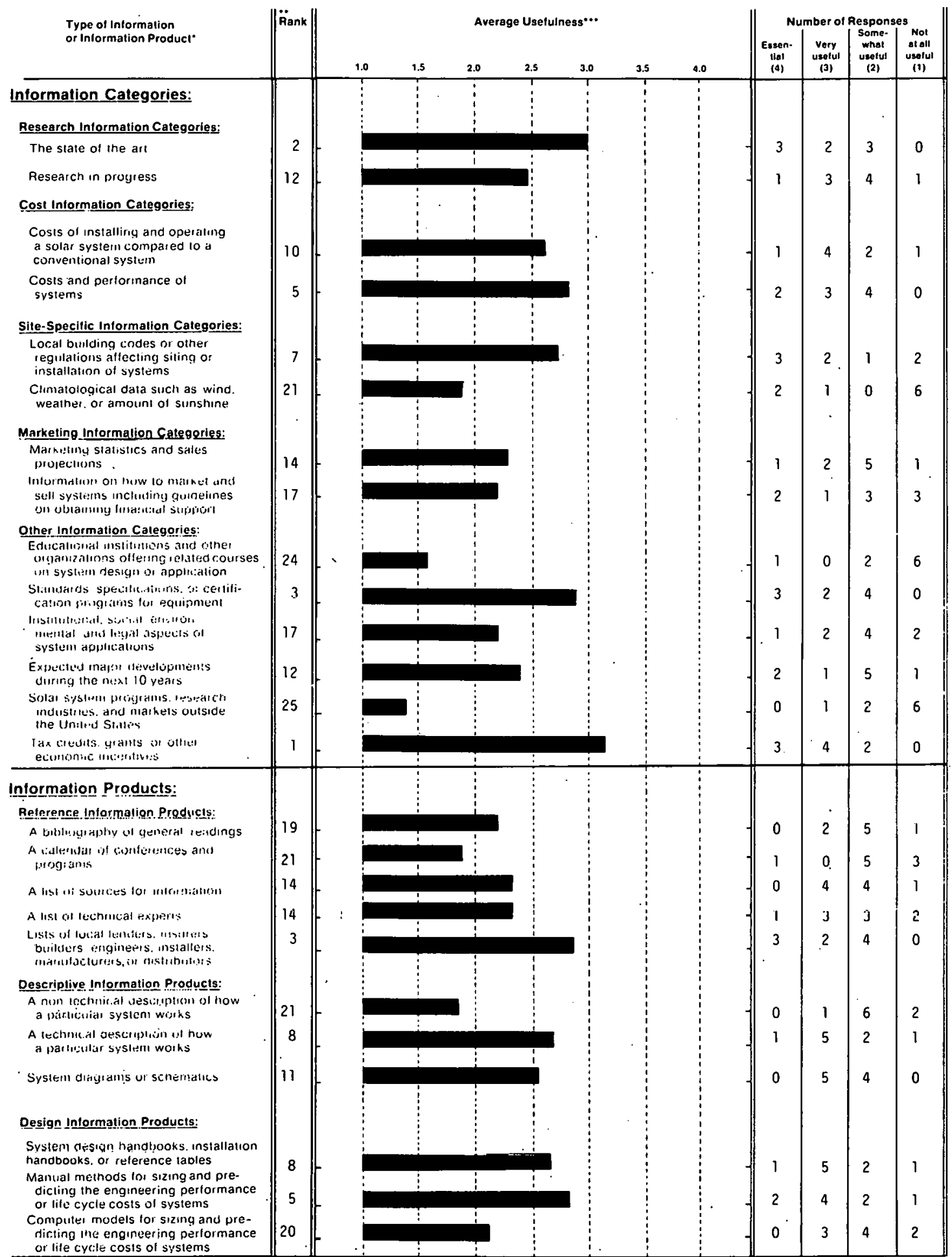

Each sa mple frame nt users was questioned on intormation and information products in the context of their specitic technology. tor example. Diomass sample trames were

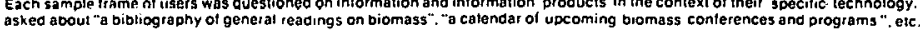
Rank-Eachintormation product was assigned a rank based on average usetulness. Thus, the producl with the highest average usetulness was assıgned ine rank of " " "I Ihe produci with the lowest average usefulness would be ranked "25" where all tems were asked. II two or more intormalion producis were tied lor 2nd. Iney were boin assigned a " 2 ". The next

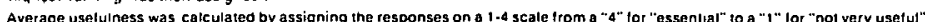

Figure 4-2. Usefulness of Selected Information Items: Biomass Conversion Equipment Manufacturer Representatives 
Question \#8. I will read a list of potential information or information products on solar systems. For each, please tell me how useful that information would be to you. Would the following be: essential, very useful, somewhat useful, or not at all useful?

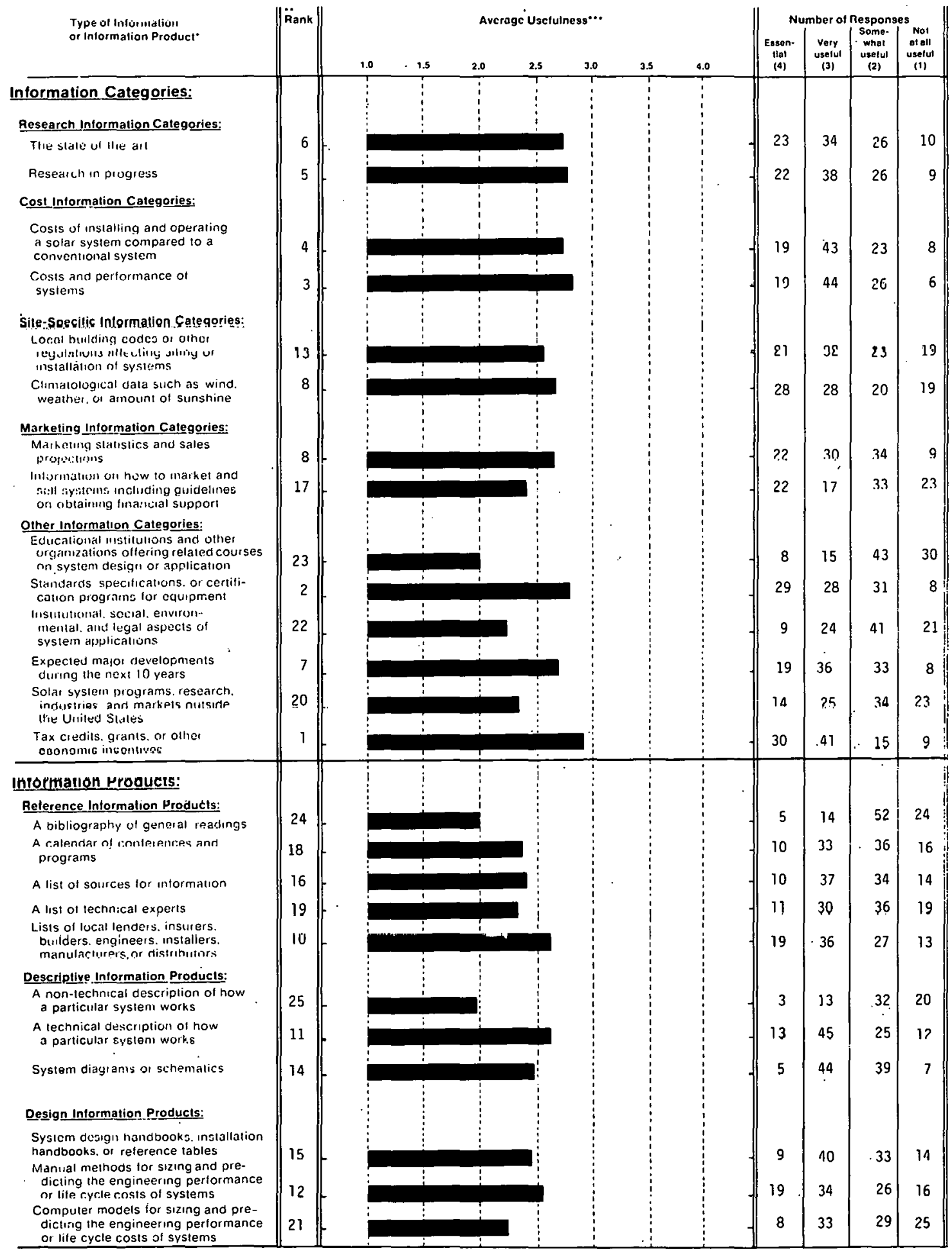

Eact sample trame of users was questioned on information and intormalion producis in the coniexl ot theit specific lechnolagy. For example, biomass sample trames were ask ed abour a bililography of general readings on biomass", "a calendar of upcoming biomass conterences and programs ", eic. Rari: -Eachiniormation producl was assigned a rank based on average useluiness. Thus. The product with the highest average uselul hess was assigned ine rank of "1": Ine product mirnions ranking was then assigned a "4"

Avel, dge uselutness wis calculated by assigning ine responses on a 1.4 scale lrom a " 4 " tor "essential" to a " 1 " tor "not very usetul"

Figure 4-3. Usefulness of Selected Information Items: All Manufacturer Representatives 
- Lists of local lenders, insurers, builders, engineers, installers, manufacturers, or distributors;

- Costs and performance of systems; and

- Manual methods for sizing and predicting performance or costs.

Representatives of Biomass Conv Manufacturers assigned the lowest ratings to:

- Solar energy programs, research, industries and markets outside the United States;

- Educational institutions and other organizations offering courses;

- Climatological data;

- Calendars of conferences and programs;

- A nontechnical description of how a particular system works; and

- Computer models for sizing and predicting performance or costs.

Statistical tests indicated that for both groups the six top-rated categories/products were rated significantly $(P<0.05)$ higher than were the lowest-rated items (five for $P \& C$ Manufacturers and six for Conv Manufacturers).

Statistical tests were used to determine whether either of the Biomass Manufacturer groups rated any of these information items significantly higher (or lower) than they were rated by the other manufacturer group or by All Manufacturers. Some groups, however, tended to give higher scores in general than did other groups to compensate for this effect, these statistical tests compared the "relative rating" given by one group to the "relative rating" given by the other groups. The procedure for calculating the relative rating is described in Appendix E. The overall average rating given by Biomass $\mathrm{P} \& \mathrm{C}$ Manufacturers was 2.42, by Biomass Conv Manufacturers 2.39, and by All Manufacturers 2.51.

It should be noted that these lowest-rated items are not necessarily of no worth to the Biomass Manufacturers. For example, 2 of the 9 (22\%) Biomass P\&C Manufacturers thought information on "institutional, social . . . aspects" was either "essential" or "very useful." Thus, these information categories/products could be useful to some Biomass Manufacturers, but were of a lower relative priority to the entire group.

Both groups of Biomass Manufacturers gave high ratings to information on "the state of the art" and "tax credits, grants, or other economic incentives." Neither gave high ratings to international programs nor to "computer models." Basically, however, there seemed to be many differences between the two groups. Compared to the Biomass Conv Manufacturers, the Biomass P\&C Manufacturers were more interested in information on "expected major developments," "a calendar of conferences and programs," "lists of sources for information," "systems diagrams or schematics," "a technical description," and "a nontechnical description." The Biomass Conv Manufacturers, on the other hand, gave higher ratings to information on "standards" and "system design handbooks."

In a statistical comparison of the two Biomass Manufacturers groups, Biomass P\&C Manufacturers gave significantly $(P<0.05)$ higher ratings to "a nontechnical description" and significantly $(\mathrm{P}<0.05)$ lower ratings to "lists of local lenders, insurers, builders (etc.)." There also appeared to be many other categories where the two differed, but the results were not statistically significant. 
A comparison of representatives of Biomass P\&C Manufacturers to All Manufacturers showed significantly $(P<0.05)$ higher ratings given by the Biomass group to "lists of sources," "systems diagrams or schematics," and "a nontechnical description" and significantly $(P<0.05)$ lower ratings given to "lists of local lenders, insurers, builders (etc.)" and "how to market and sell solar systems."

Compared to All Manufacturers, representatives of Biomass Conv Manufacturers gave significantly $(P<0.05)$ lower ratings to "solar energy programs, research $\ldots$. outside the United States" and "climatological data." There also was evidence that Biomass Conv Manufacturers were less interested in "research in progress," but more interested in "local building codes," "lists of local lenders (etc.)," "system design handbooks," and "manual methods."

\subsection{ACQUISITION OF INFORMATION BY RESPONDENTS}

\subsubsection{Use of Selected Information Sources}

Representatives of Biomass Manufacturers were asked which of 21 different potential sources of solar information they had used in the past few years. For this question the respondents were not asked if they had obtained information on biomass energy, but instead were asked if they had obtained any solar information from each specific source. Thus, the question sought to determine which information sources were the most familiar to the respondents. The results are shown in Figs. 4-4 and 4-5. For the purpose of comparison, the results for All Manufacturers (Fig. 4-6) are also included.

The information sources mentioned most often by representatives of Biomass P\&C. Manufacturers were:

- Periodicals, newspapers, or magazines;

- Radio or TV; and

- The Government Printing Office (GPO).

The information sources mentioned most often by representatives of Biomass Conv Manufacturers were:

- Periodicals, newspapers, or magazines; and

- Private solar energy or environmental organizations.

The information sources mentioned least of ten hy representatives of Biomass P\&C Manufacturers were:

- Private solar energy or environmental organizations,

- Solar Energy Industries Association (SEIA),

- A commercial data base,

- Bio-Energy Council,

- International Solar Energy Society (ISES),

- Technical Information Center (TIC), 
Question \#11. In the past few years, have you obtained any type of solar information from any of the following sources?

Information Sources

Percentage Responding Yes ${ }^{\cdots}$

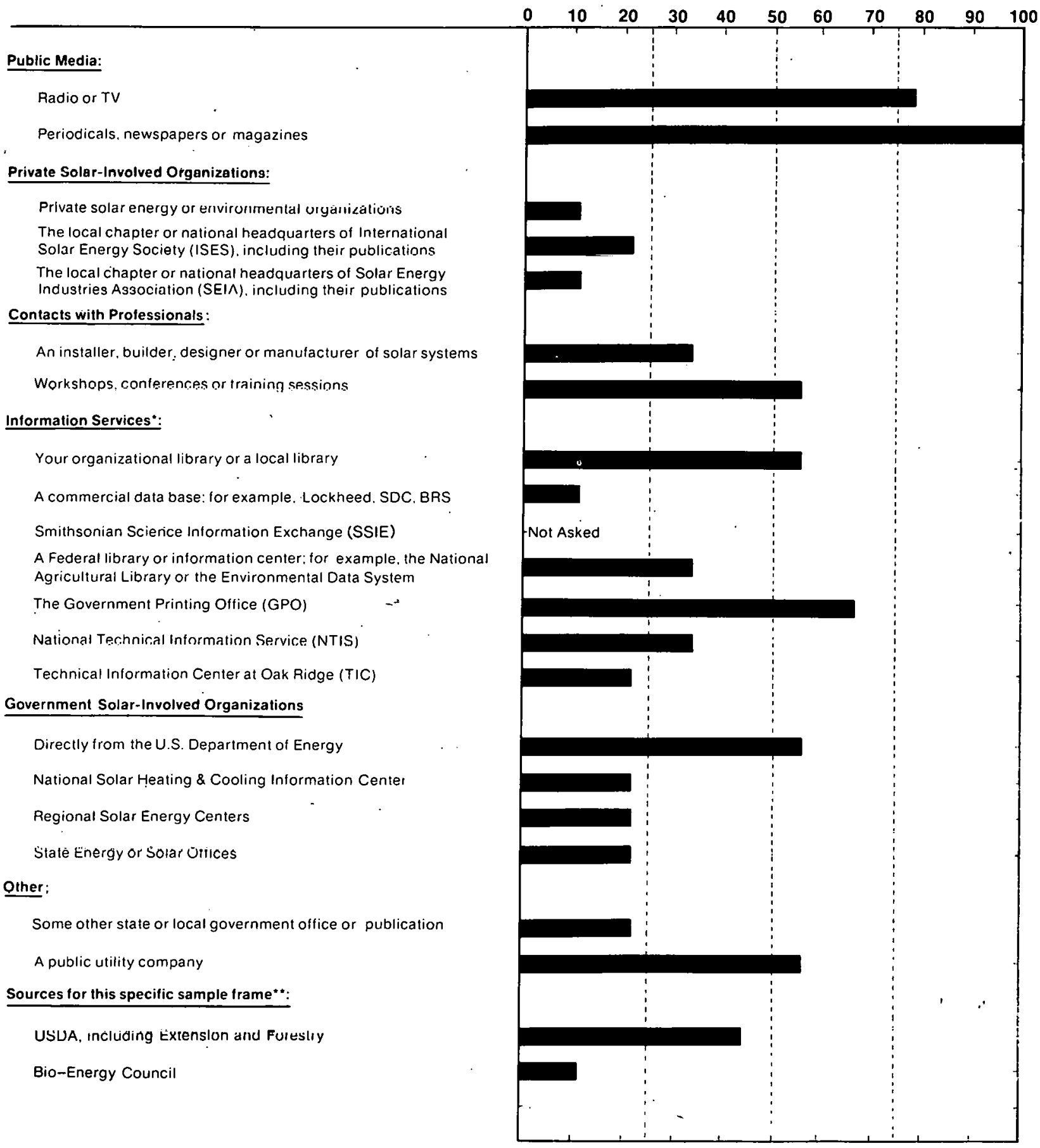

- Services and centers whose primary purpose is to disseminate information

Somc sample frames were questioned about additional information snurces which are applicable to their technology. For example. the manufacturers of biomass conversion equipment were also asked it they have obtained any iype of solar information irom: "the local or national office of the U.S. Department of Agriculture. including Extension and Forestry."

... These data are based upon a total of 9 respondents.

Figure 4-4. Use of Selected Information Sources: Biomass Production and Collection Equipment Manufacturer Representatives 
Question \#11. In the past few years, have you obtained any type of solar information from any of the following sources?

\section{Information Sources}

Percentage Responding Yes $\ldots$

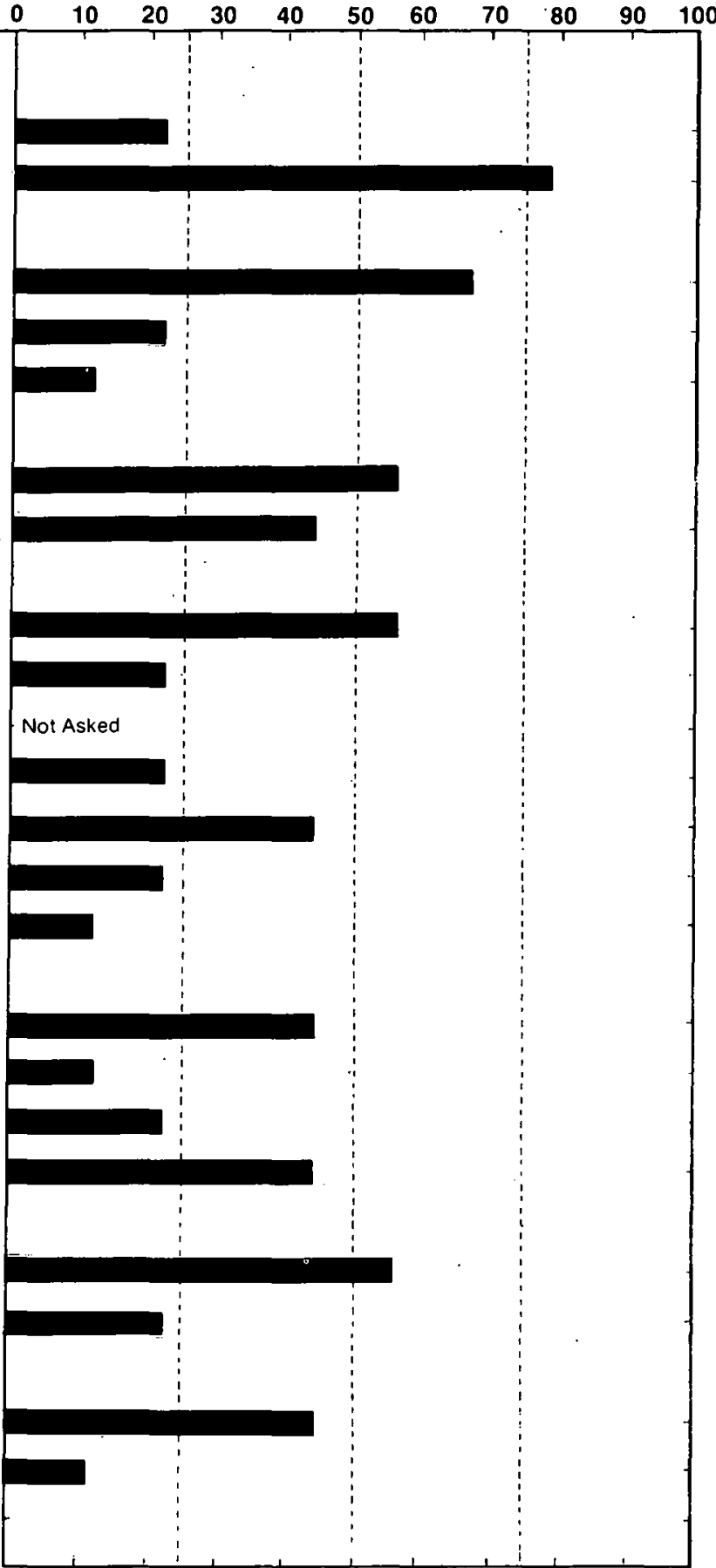

Periodicals. newspapers or magazines

Private Solar-Involved Organizations:

Private solar energy or environmental organizations

ine Iocal chapter or national headquariers of Internationai

Solar Energy Society (ISES). including their publications

The local chapter or national headquarters of Solar Energy

Industries Association (SEIA). includinq thẹir publiçations

Contacts with Professionals:

An installer, builder, designer or manufacturer of solar systems

Workshops, conferences or training sessions

Information Services*:

Your organizational library or a local library

A commercial data base: for example. Lockheed. SDC. BRS

Smithsonian Science Information Exchange (SSIE)

A Federal library or information center: for example. the National

Agricultural Library or the Environmental Data System

The Government Printing Office (GPO)

National Technical Information Service (NTIS)

Technical Information Center at Oak Ridge (TIC)

Government Solar-involved Organizations

Directly from the U.S. Department of Energy

National Solar Heating \& Cooling Information Center

Regional Solar Energy Centers

State Energy, or Soler Officos

Other:

Some other state or local government office or publication

A public utility company

Sources for this specific sample frame**:

USDA, including Extension and Forestry

Rin-Fnęrgy Conıncil

-


Question \#11. In the past few years, have you obtained any type of solar information from any of the following sources?

Information Sources

Public Media:
Radio or TV
Periodicals. newspapers or magazines
Private Solar-Involved Organizations:
Private solar energy or environmental organizations
The local chapter or national headquarters of international
Solar Energy Society (ISES). including their publications
The local chapter or national headquarters of Solar Energy
Industries Association (SEIA). including their publications
Contacts with Protessionals:

An installer, builder, designer or manufacturer of solar systems

Workshops. conferences or training sessions

Intormation Services*:

Your organizational library or a local library

A commercial data base: for example. Lockheed. SDC. BRS

Smithsonian Science Information Exchange (SSIE)

A Federal library or information center: for example. the National Agricultural Library or the Environmental Data System

The Government Printing Office (GPO)

Nationa! Technical Information Service (NTIS)

Technical Information Center at Oak Ridge (TIC)

Government Solar-Involved Organizations

Direcily from the U.S. Department of Energy

National Solar Heating \& Cooling Information Center

Regional Solar Energy Centers

Stalu E!rurgy or Solar Dllicul

Other:

Some other state or local government office or publication

A public utility company
Percentage Responding Yes *

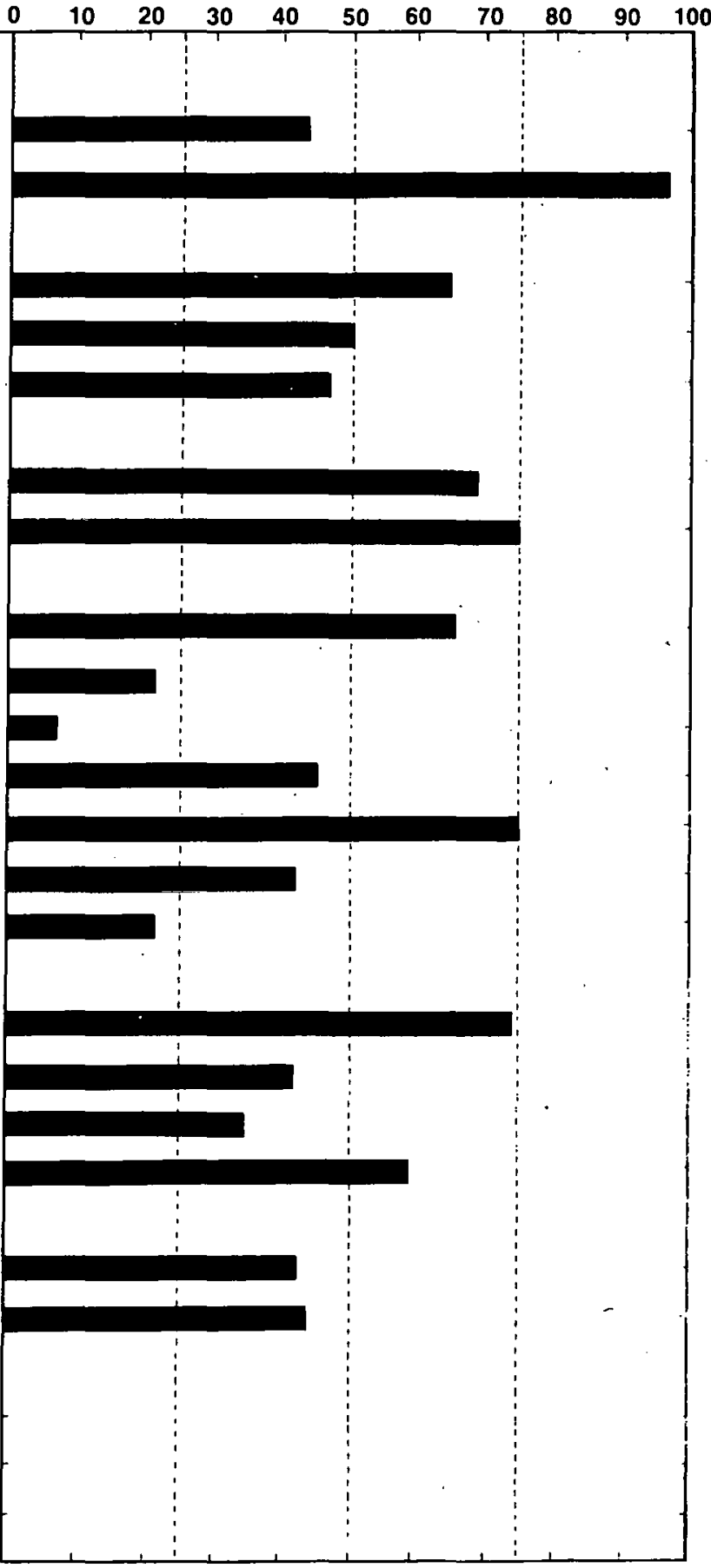

- Services and centers whose primary purpose is to disseminate intormation.

- These data are based upon a total ol 96 resuondents.

Figure 4-6. Use of Selected Information Sources: All Manufacturer Representatives 
- National Solar Heating and Cooling Information Center (NSHCIC),

- Regional Solar Energy Centers (RSECs),

- State energy or solar offices, and

- Some other state or local government office or publications.

The information sources mentioned least often by representatives of Biomass Conv Manufacturers were:

- SEIA,

- TIC,

- NSHCIC,

- Dió-Energy Cüuneil,

- Radio or TV,

- ISES,

- A commercial data base,

- A federal library or information center,

- National Technical Information Service (NTIS),

- RSECs, and

- A public utility company.

Very few of the 21 different potential sources of solar information were used by many of the Biomass Manufacturer representatives. Only 7 of the 21 sources were mentioned by more than half of the P\&C Manufacturers and only 5 of the 21 sources were mentioned by more than half of the Conv Manufacturers. For only 3 of the 19 sources (about which All Manufacturers were asked) did the percentage of Biomass P\&C Manufacturers using the -source exceed the percentage of users in All Manufacturers. Similarly, for only 2 of the 19 sources did the percentage of Biomass Conv Manufacturers using the source exceed the percentage of users in All Manufacturers.

\subsubsection{Membership in Solar-Interested Organizations}

Five of the 9 representatives of Biomass P\&C Manufacturers interviewed were members of a professional, technical, or other organization with an interest in solar energy. These organizations (each receiving a single mention) included:

- American Chemical Society;

- American Institute of Chemical Engineers;

- American Society of Heating, Refrigerating and Air Conditioning Engineers;

- American Pulpwood Association;

- Association of Energy Engineers;

- Michigan Energy and Resources Association;

- Michigan Forest Products Council; 
- Society of American Foresters (SAF); and

- Wood Energy Institute.

Similarly, 5 of the 9 representatives of Biomass Conv Manufacturers interviewed were also members of a professional, technical, or other organization with an interest in solar energy. These organizations (and the number of times mentioned) included:

- American Society of Mechanical Engineers (2),

- Connecticut River Watershed Council,

- Forest Products Research Society,

- New England Solar Energy,

- SAF,

- Society for the Protection of New Hampshire Forests, and

- Wind Energy Institute (WEI).

Also receiving a single mention was "National Solid Fuel Trade Association," an organization which could not be verified by the authors.

\subsubsection{Exposure to Publications on Solar Energy}

During the past 6 months, 8 of the 9 representatives of Biomass P\&C Manufacturers had read publications which included information on biomass energy. The publications they could specify (each receiving a single mention) included:

- Air Gasification Conference minutes;

- Coal publications (i.e., utilization of coal, problems getting it moving as an alternative fuel source, coal slurry lines, mixing coal with water and moving it thru pipe lines, pumping from coal source to user);

- Energy for Survival, the Alternative to Extinction (book by Wilson Clark);

- Energy Unlimited (publication by Morbark Industries);

- Energy User News;

- Louisiana Pacific publications: "Biomass, a Particular Solution to Every Situation";

- Lumberman (Southern);

- MERRA publications (Michigan Energy and Resource, Resource Association);

- Pulpwood and Panel; and

- Sólid Wáste Managenent.

Also receiving single mentions were several publications which could not be verified by the authors, i.e., "B\&A Reports" and "technical journals."

All 9 of the Biomass Conv Manufacturer representatives had read publications during the past 6 months that included biomass energy. The publications they could specify (and the number of times mentioned) included: 
- Compost Science;

- Design Operation, Small Sewage (publication by Baines);

- Fuel Oil News (2);

- Heating, Piping and Air Conditioning;

- Mechanical Engineering;

- Mother Earth News;

- New Roots;

- Pollution Engineering;

- Power;

- Solar Age;

- Solar Energy;

- Solar Energy Research Institute (SERI) Biomass conference;

- A Survey of Biomass Gasification (SERI report);

- Solar Heating and Cooling;

- TAPPI (Technical Association of the Pulp and Paper Industry); and

- Wood Burners' Encyclopedia (book by Shelton).

Also receiving single mentions were some publications which could not be verified by the authors. These included "Animal Waste Manager (publication by Ohr)," "BioSolar Conservation," "Fireplace Journal," "Logger and Timberman," "Solar Heating," "Woodburning Quarterly," "trade journals," "local papers (Chattanooga, Tennessee)," und "Firewưud and Fireplaces."

None of the publications mentioned above were common to both groups of Biomass Manufacturers.

\subsubsection{Use of Special Acquisition Methods}

The respondents were asked whether they had obtained any information (not just biomuss or solar energy) in the past year by computer terminal, by Computer Output Microform (COM), or by other microform (è.g̈., microflche, mirofillin slieets ur rulls). Few Diomass Manuf acturers appeared accustomed to using these special acquisition methods, a trait common to manufacturers in all technologies studied. In the past year, only 1 of the 9 (11\%) in each group of Biomass Manufacturers had used a computer terminal, none had used COM, and only 1 (11\%) in each group had used other microform.

\subsection{SUMMARY AND COMMENTS}

Eighteen representatives of manufacturers involved in the production of equipment for biomass energy were interviewed, nine in production and collection equipment and nine in conversion equipment. Biomass P\&C Manufacturers were somewhat less educated than Biomass Conv Manufacturers and significantly $(P<0.05)$ less educated than All Manufacturers. Representatives of Biomass P\&C Manuf acturers had been in their current profession somewhat longer than representatives of Biomass Conv Manufacturers. 
Representatives of Biomass P\&C Manufacturers gave the highest priority to receiving information on:

- Lists of sources for information on biomass energy systems;

- A technical description of how a particular biomass energy system works;

- Biomass processing system diagrams or schematics;

- The state of the art in biomass energy systems;

- Expected major developments in biomass energy applications during the next 10 years; and

- Tax credits, grants, or other economic incentives for biomass energy applications.

Biomass Conv Manufacturers gave the highest priority to receiving information on:

- Tax credits, grants, or other economic incentives for biomass energy applications;

- The state of the art in biomass energy systems;

- Standards, specification, or certification programs for biomass energy equipment or installations;

- Lists of local lenders, insurers, builders, engineers, installers, manufacturers, or distributors for biomass energy systems;

- Costs and performance of biomass energy systems; and

- Manual methods for sizing and predicting performance or costs of biomass energy systems.

Biomass P\&C Manufacturers gave low ratings to "how to market and sell solar systems," "solar energy programs, research . . . outside the United States," "lists of local lenders (etc.)," "computer models," and "institutional, social . . a aspects."

Biomass Conv Manufacturers gave low ratings to "solar energy programs, research . . outside the United States," "educational institutions," "climatological data," "calendars," "a nontechnical description," and "computer models."

Both groups of Biomass Manufacturers gave high ratings to "the state of the art" and "tax credits, grants, or other economic incentives." Neither gave high ratings to international programs nor to "computer models." . Nevertheless, there seemed to be many differences between the two groups. Compared to the Conv Manufacturers, the Biomass P\&C Manufacturers appeared more interested in information on "expected major developments," "calendars of conferences and programs," "lists of sources for information," "systems diagrams or schematics," "a technical description," and "a nontechnical description." The Biomass Conv Manufacturers, on the other hand, gave higher ratings to information on "standards" and "system design handbooks." In comparison to All Manufacturers, again Biomass P\&C Manufacturers indicated substantially different information needs.

Biomass Equipment Manufacturers used very few sources for information on solar energy. The only source mentioned by the majority of respondents in both groups was "periodicals," (also the most popular source identified by All Manufacturers). Biomass P\&C Manufacturers also frequently mentioned "radio or TV" and GPO, while Biomass 
Conv Manufacturers frequently mentioned "private solar energy or environmental organizations." Neither the USDA nor the Bio-Energy Council served as vital sources. Both groups mentioned a wide variety of organizations and publications from which they obtain solar information, but none were mentioned with any frequency. Based upon these results it would appear that the best way to reach Biomass Manufacturers might be through direct contact rather than through existing channels. 


\section{SECTION 5.0}

\section{BIOMASS STATE FORESTRY OPFICE REPRESENTATIVES}

\subsection{DESCRIPTION OF RESPONDENTS}

\subsubsection{Description of Sample}

This section describes the results of a telephone study to determine the needs of representatives of State Forestry Offices for information on biomass energy systems. Representatives of 9 State Forestry Offices were interviewed.

The sample frame for Biomass State Forestry Office Representatives was constructed from the 1979 Directory of the Forest Products Industry [6] list of "State Foresters in the United States." Contact names were the heads of such organizations as the State Forestry Commission or Service, State Land Department (Forestry Division), State Department of Agriculture (Forestry Section), State Department of Natural Resources (Forestry Division), State Conservation Commission (Forestry Division), etc. One contact name was provided for each state except Connecticut. Alaska and Hawaii contacts were not used. The 9 interview candidates were randomly selected from a sample frame of 47 names.

Respondents. In making the telephone calls to contact the randomly selected interview candidates, it sometimes occurred that the person could not be reached. In this event another randomly selected name was substituted for the original name. When individuals were contacted, it was verified that they really were representatives of the State Forestry Office and that they would be needing information on biomass energy within the next year. If they were not both involved and needing information, they were asked if they could refer the interviewer to someone else in their organization who would be an appropriate respondent. If such a referral was made, a call was then made to this new candidate; if no intraorganizational referral was made, a new candidate was randomly selected from the sample frame. The results of this process may be seen in Table 5-1.

Comparisons. For additional insight into the information needs and the information habits of these Biomass State Forestry Office Representatives, results from this group are compared to the results for Biomass Private Foresters and for Biomass Forest Products Engineers/Consultants interviewed in this study. The data for Biomass State Forestry Office Representatives, Biomass Private Foresters, and Biomass Forest Products Engineers/Consultants can be found in Appendix F.

\subsubsection{Current Status of Respondents}

Role. Five of the Biomass State Forestry Office Representatives specifically mentioned that they were arranging for the supply of wood for fuel. One of the 5 was selling wood fuel and the other 4 were providing wood to: area residents (2), electric utilities for wood-fired generating plants, and a university steam power system as a supplementary source. Other activities conducted by the State Forestry Office Representatives on biomass included: data collection on biomass energy systems and related applications; volume estimates of timber (in their state); maintaining inventories on wood stoves and wood-fired boilers; providing marketing assistance to wood manufacturing industries on 
wood waste; plantation production of wood for fuel; research and demonstration; combining wood with urban waste for fuel; and assembling some ideas on available resources related to forestry.

Table 5-1. COMPLETION OF INTERVIEWS: BIOMASS STATE FORESTRY OFPICE REPRESENTATTVES

Event

Number of

Candidates

Interview completed with sample frame candidate

6

Interview completed with referral candidate

3

Refusal or candidate termination

$\mathbf{0}$

Contact attempted: could not reach candidate within three attempts,

or before interviews were completed

\section{8}

Subtotal

Contact attempted: invalid candidate (e.g., inappropriate

field of interest, no telephone)

TOTAL

Sample frame error rate ${ }^{\mathrm{a}}$ (Percent)

a Invalid candidate divided by TOTAL

${ }^{\text {Completed interviews divided by Subtotal }}$

Involvement. Six of the 9 (67\%) Biomass State Forestry Office Representatives said that they were "very involved." This level of involvement was significantly higher than that of the Biomass Private Foresters, with 1 of the 9 (11\%) "very involved" and slightly higher than that of the Biomass Forest Products Engineers/Consultants, with 4 of the 8 (50\%) "very involved."

Informedness. Four of the 9 (44\%) Biomass State Forestry Office Representatives considered themselves "very informed" and 3 of the 9 (33\%) "moderately informed." Comparatively, only 2 of the 9 (22\%) Biomass Private Foresters considered themselves "very informed," but 6 of the 9 (67\%) were "moderately informed." Of the Biomass Forest Products Engineers/Consultants, 6 of the 8 (75\%) were "very informed" and l of the 8 (13\%) "moderately informed." The differences in levels of informedness stated by the three groups did not differ significantly.

Need for Information. All 9 Biomass State Forestry Office Representives, all 9 Biomass Private Foresters, and 7 of the 8 Biomass Forest Products Engineers/Consultants indicated they would need information on biomass energy on the job during the next year. Five of the 9 (56\%) Biomass State Forestry Office Representatives also expected to need information on biomass energy off the job. This was similar to the results for Biomass Private Foresters and Biomass Forest Products Engineers/Consultants, where 6 of the 9 $(67 \%)$ and 5 of the $8(63 \%)$, respectively, indicated they would need biomass information outside the job. 


\subsubsection{Background of Respondents}

Four of the 9 Biomass State Forestry Office Representatives held bachelor's degrees, 3 held master's degrees, and 2 held doctoral degrees. A comparison to the other two groups showed the Biomass State Forestry Office Representatives ( 5 of the 9) to have the highest proportion of advanced degrees and the Biomass Forest Products Engineers/ Consultants (2 of the 8 ) to have the lowest proportion. Six of the Forestry Office Representatives had received degrees in forestry or forest management, and 1 each in sociology, natural resources economics, and public administration. Degrees in forestry were also prevalent among the Biomass Private Foresters, with all 9 receiving degrees in forestry or forest management. In contrast, only 1 respondent in the Biomass Forest Products Engineers/Consultants group had a degree in forestry and 4 of the 8 had degrees in engineering.

Two Biomass State Forestry Office Representatives received their most recent degree over 40 years ago, 2 from 20-30 years ago, 3 from 10-20 years ago, and 2 from 5-10 years ago. The dates of degrees received by this group appeared similar to those of Biomass Private Foresters and Biomass Forest Products Engineers/Consultants.

Only 1 respondent in the Forestry Office group had been in his/her current profession for 3-5 years, with the other 8 respondents having over 10 years experience; this level of experience was similar to that of the other two groups of biomass foresters/engineers interviewed. All 9 respondents interviewed at the Biomass State Forestry Offices were foresters, with 6 of the 9 (67\%) stating that they were in administrative/management positions.

\subsection{INPORMATION NEEDS OF RESPONDENTS}

\subsubsection{Technical Areas}

Biomass State Forestry Office Representatives were asked to choose those areas in which they were "particularly interested in obtaining information" from a list of selected technical areas of biomass energy (see Table 5-2). A generally high level of interest was expressed in all six technical areas studied, with unanimous interest in "commercial or industrial burning of biomass." This technical area also elicited the highest interest levels for both Biomass Private Foresters and Biomass Forest Products Engineers/Consultants. Of the other five technical areas, more Biomass State Forestry Office Representatives appeared to have a greater interest in "liquid fuels from biomass materials" and "residential burning of wood" than did the other groups.

\subsubsection{Types of Information}

Biomass State Forestry Office Representatives were asked to name the information about biomass energy that was important for them to obtain. All 9 volunteered one or more items of information which they considered important. Topics volunteered included information on: conversion of raw materials, industrial systems, a realistic analysis of uses of biomass, current research, economical harvesting systems, updated information, information on handling system equipment, methods for storing biomass feedstock, methane gas production, industrial uses of cogeneration, and "information we can pass on to mills (furniture and saw mills)." 
Table 5-2. AREA OF INTBREST: BIOMASS STATE FORESTRY OFFICE REPRESENTATIVES, BIOMASS PRIVATE FORESTERS, AND BIOMASS FOREST PRODUCTS ENGINEERS/CONSULTANTS

\begin{tabular}{|c|c|c|c|c|c|c|}
\hline \multirow[t]{2}{*}{ Technical Area of Interest } & \multicolumn{3}{|c|}{$\begin{array}{l}\text { Biomass } \\
\text { State } \\
\text { Forestry } \\
\text { Office } \\
\text { Represen- } \\
\text { tatives }\end{array}$} & \multicolumn{2}{|c|}{$\begin{array}{l}\text { Biomass } \\
\text { Private } \\
\text { Foresters }\end{array}$} & \multirow{2}{*}{ 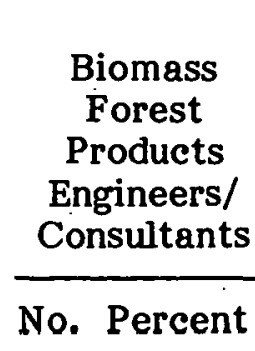 } \\
\hline & No. & Perc & ent & No. & Percent & \\
\hline $\begin{array}{l}\text { Commercial or Industrial Burning } \\
\text { of Biomass } \\
\text { Burnable Pellets, etc., from Biomass } \\
\text { Growth or Collection of Biomass Materials } \\
\text { Residential Burning of Wood } \\
\text { Gases from Biomass Materials } \\
\text { Liquid Fuels from Biomass Materials }\end{array}$ & $\begin{array}{l}8 \\
8 \\
8 \\
8 \\
7 \\
7\end{array}$ & $\begin{array}{l}100 \\
89 \\
89 \\
89 \\
78 \\
78\end{array}$ & $\begin{array}{l}7 \\
7 \\
6 \\
3 \\
3 \\
2\end{array}$ & $\begin{array}{l}78 \\
78 \\
67 \\
33 \\
33 \\
22\end{array}$ & $\begin{array}{l}788 \\
675 \\
563 \\
450 \\
563 \\
563\end{array}$ & \\
\hline
\end{tabular}

Four of the 9 Biomass State Forestry Office Representatives volunteered they needed but were unable to get information on biomass energy. The specific information items needed, however, were not mentioned.

Choice Between Specific Needs. A list of 11 types of biomass energy information products and 13 types of biomass energy information categories was read to each respondent. Each respondent described the usefulness of each particular item by assigning it a value of "essential," "very useful," "somewhat useful," or "not at all useful." The results are given in Fig. 5-1. For the purpose of comparison, the results for Biomass Private Foresters and Biomass Forest Products Engineers/Consultants may be found in Figs. 6-1 and $7-1$, respectively.

Biomass State Forestry Office Representatives selected the research information categories as most important. The seven top-rated information categories/products were:

- 'I'he state of the art;

- Research in progress;

- Expected major developments during the next 10 years;

- Lists of toolunical experts;

- Costs of installing and operating a biomass energy system compared to a conventional system;

- Institutional, social, environmental, and legal aspects; and

- Tax credits, grants, or other economic incentives.

Biomass State Forestry Office Representatives assigned the lowest relative ratings to:

- Solar energy programs, research, industries, and markets outside the United States; 
Question \#8. I will read a list of potential information or information products on solar systems. For each, please tell me how useful that information would be to you. Would the following be: essential, very useful, somewhat useful, or not at all useful?

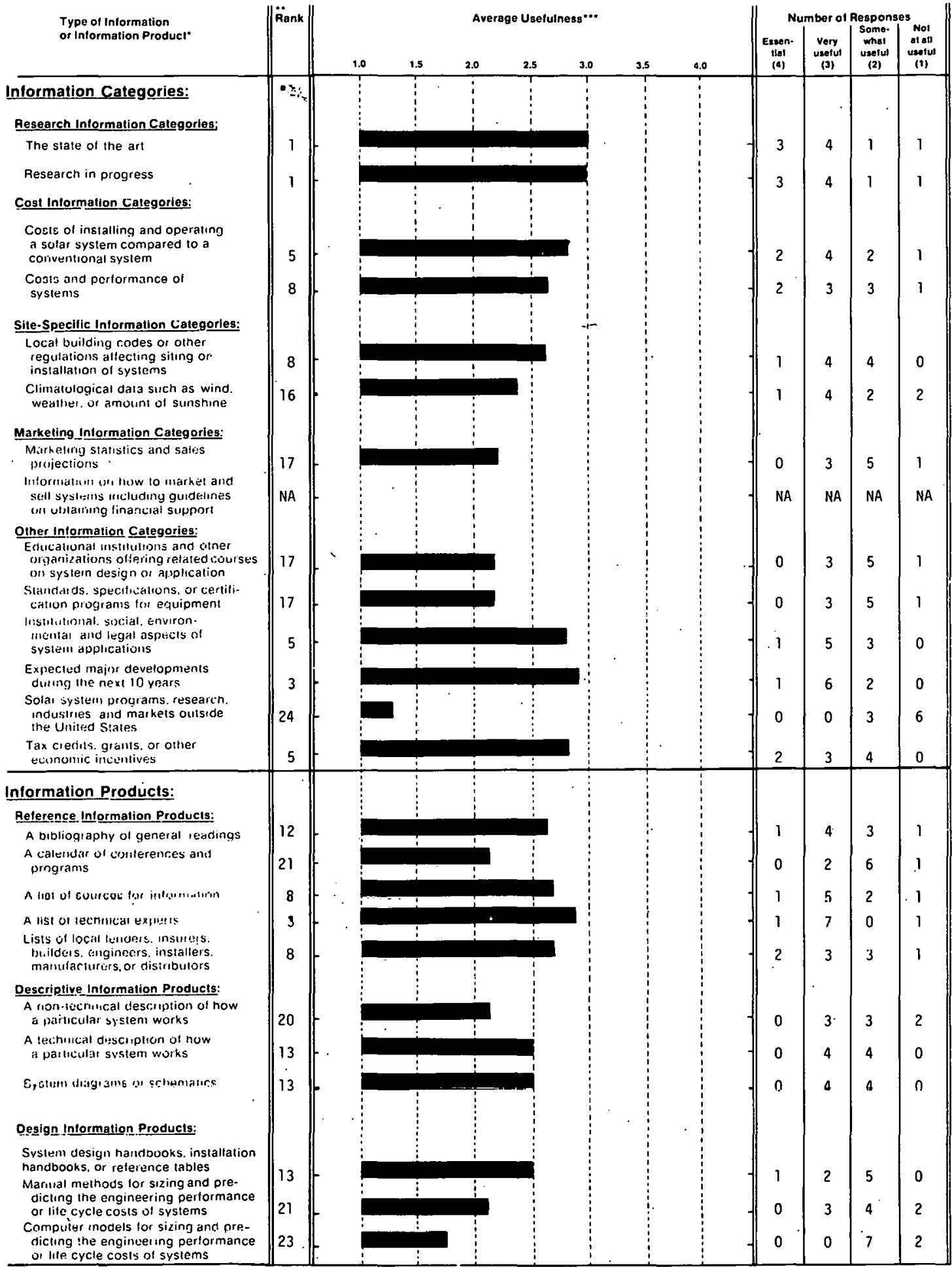

Eact sample frame of users was questioned on intormation and intormation products in ine context of their specilic technology. For example. biomass sample trames were

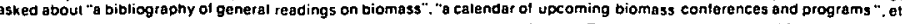

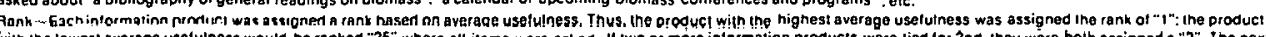
(tor znd, they were both assigned a " 2 ". the next

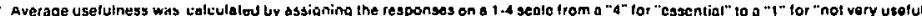

Figure 5-1. Usefulness of Selected Information Items: Biomass State Forestry Offlce Representatives 
- Computer models for sizing and predicting performance or costs;

- Calendars of conferences and programs; and

- Manual methods for sizing and predicting performance or costs.

Statistical tests indicated all seven of the top-rated categories/products were rated significantly $(P<0.05)$ higher than were the four lowest-rated items.

It should be noted that these lower-rated items were not necessarily of no worth to the Biomass State Forestry Office Representatives. For example, 3 of the 9 (33\%) thought "a nontechnical description" was "very useful." Thus, these information categories/ products could be useful to some Biomass State Forestry Office Representatives, but were of a lower relative priority to the entire group.

Statistical tests were also used to determine whether the Biomass State Forestry Office Representatives rated any of these information items significantly higher (or lower) than they were rated by the Biomass Private Foresters or the Biomass Forest Products Engineers/Consultants. Some groups, however, tended to give higher scores in general than did other groups. To compensate for this effect, these statistical tests compared the "relative rating" given by one group to the "relative rating" given by the other groups. The procedure for calculating the relative rating is described in Appendix $\mathrm{E}$. The average overall rating Biomass State Forestry Office Representatives gave to all items was 2.48, for Biomass Private Foresters it wás 2.08, and for Biomass Forest Products Engineers/Consultants, 2.63.

Statistical tests indicated that, compared to Biomass Private Foresters, Biomass State Forestry Office Representatives rated the need for information on "local building codes" significantly $(P<0.05)$ higher. They also appeared to give higher ratings to "research in progress," "institutional ... aspects," and bibliographies.

Compared to the Biomass Forest Products Engineers/Consultants group, the Blomass State Forestry Office Representatives gave significantly $(P<0.05)$ higher ratings to "educational institutions," and "expected major developments"; significantly $(P<0.05)$ lower ratings to "manual methods for sizing" and "solar energy programs, research ... outside the United States." They also appeared to give higher ratings to "state of the art," "research in progress," bibliographies, "lists of technical experts," "lists of local lenders (etc.)," and "a technical description."

\subsection{AQUंSTION OF INFORMATION BY RESPONDENTS}

\subsubsection{Use of Selected Information Sources}

Biomass State Forestry Office Representatives were asked which of 23 different potential sources of solar information they had used in the past few years. For this question the respondents were not asked if they had obtained information on biomass energy, but instead were asked if they had obtained any solar information from each specific source. Thus, the question sought to determine which information sources were the most familiar to the respondents. The results are shown in Fig. 5-2. For the purpose of comparison, the results for Biomass Private Foresters and Biomass Forest Products Engineers/ Consultants may be found in Chapters 6 and 7 in Figs. 6-2 and 7-2, respectively. 
Question \#11: In the past few years, have you obtained any type of solar information from any of the following sources?

Information Sources

$\frac{\text { Public Media: }}{\text { Radio or TV }}$
- Pegrigrirals newapapiersnr magazines

Private Solar-Involved Organizations:

Private solar energy or environmental organizations

The local chapter or national headquarters of International Solar Energy Society (ISES). including their publications

The local chapter or national headquarters of Solar Energy

Industries Association (SE|A). including their publications

Contacts with Professionals:

An installer, builder. designer or manufacturer of solar systems

Workshops. conferences or training sessions

Information Services*:

Your organizational library or a local library

A commercial data base: for example. Lockheed. SDC. BRS

Smithsonian Science Information Exchange (SSIE)

A Federal library or information center: for example. the Nationa Agricultural Library or the Environmental Data System

The Covernment Printing Officc (GPO)

National Technical Information Service (NTIS)

Technical Information Center at Oak Ridge (TIC)

Government Solar-Involved Organizations

Directly from the U.S. Department of Energy

National Solar Heating \& Cooling Information Cente।

Regional Solar Energy Centers

Siate. Fneroy or Solar Offices

Other:

Some other state or local government office or publication

A public utility rompany

Sources for this specific sample frame".

USDA, including Extension and Forestry

Bio-Eneray Council

Wood Energy Institute
Percentage Responding Yes $\cdots$

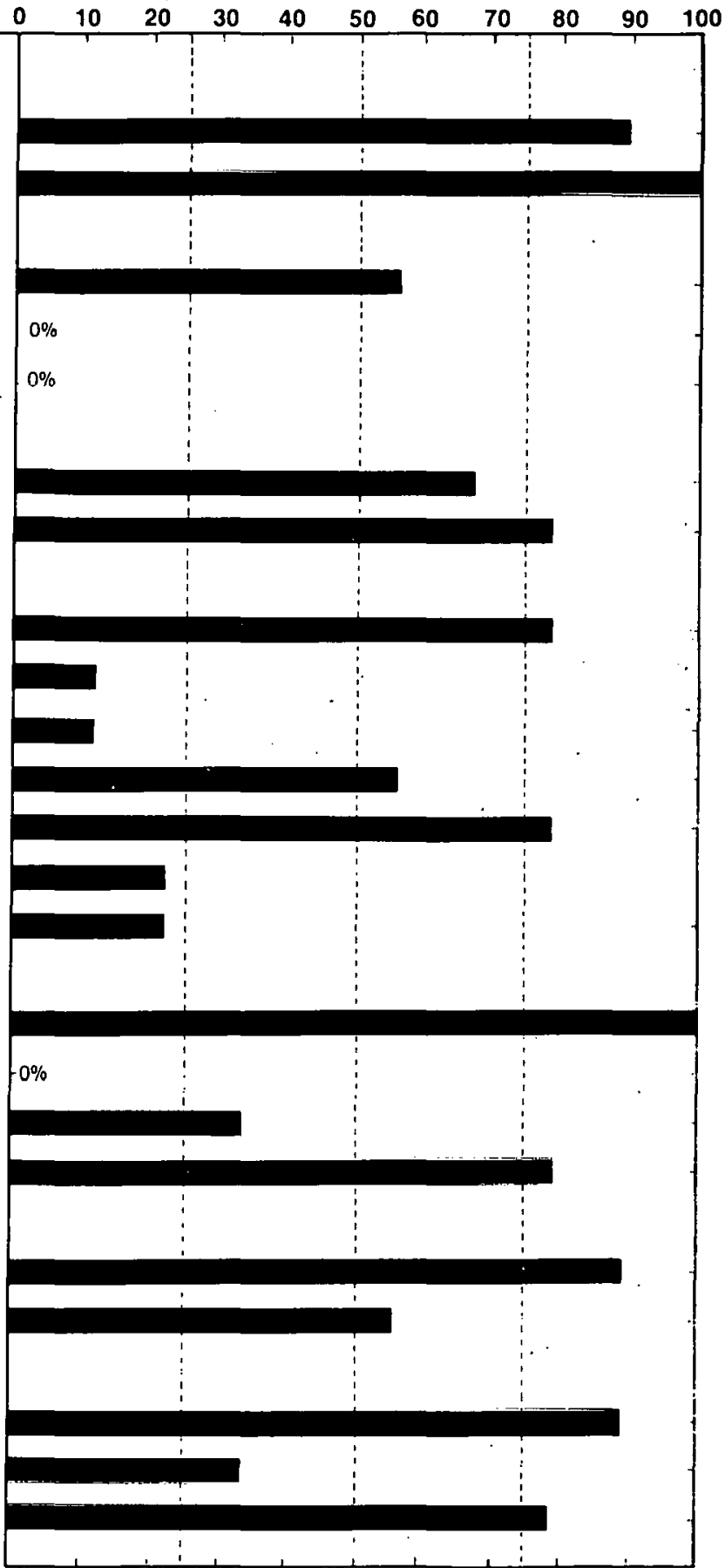

$\because$ Services and centers whose primary purpose is to disseminate information.

Some sample frames were questioned about additional information sources which are applicable to theır technology. For example. lhe manufacturers of biomass conversion equipment were also asked it they have obtained any type of solar intormation from: "the local or national office of the U.S. Department of Agriculture, including Extension and Forestry."

... These data are based upon a intai ni 9 respondents.

Figure 5-2. Use of Selected Information Sources: Biomass State Forestry Office Representatives 
The information sources mentioned most of ten by Biomass State Forestry Office Representatives (each used by at least 7 of the 9) were:

- Periodicals, newspapers, or magazines;

- Directly from the U.S. Department of Energy (DOE);

- Radio or TV;

- Some other state or local government office or publications;

- U.S. Department of Agriculture (USDA), including Extension and Forestry;

- Workshops, conferences, or training sessions;

- An organizational library or a local library;

- Government Printing Office (GPO);

- State energy or solar offices; and

- Wood Energy Institute (WE1).

The information sources mentioned least of ten by Biomass State Forestry Office Representatives (none used by more than 2 of the 9) were:

- International Solar Energy Society (ISES),

- Solar Energy Industries Association (SEIA);

- National Solar Heating and Cooling Information Center (NSHCIC),

- A commercial data base,

- Smithsonian Science Information Exchange (SSIẼ),

- National Technical Information Service, (NTIS) and

- Technical Information Center (TIC):

Of the three biomass groups studied, the Biomass State Forestry Office Representatives had the most respondents using the largest variety of information sources; Biomass Private Foresters used the least variety. A total of 14 of the 23 (61\%) sources were mentioned by half or more of the State Forestry Office Representatives, compared to 11 of the $22(50 \%)$ mentioned by at least half of the Biomass Forest Products Engineers/ Consultants and 4 of the 21 (19\%) by at least half of the Biomass Private Foresters. In comparing the information sources used by Biomass State Forestry Office Representatives to those used by Biomass Private Foresters and Biomass Forest Products Engineers/ Consultants, significantly $(\mathrm{P}<0.05)$ more respondents at the State Forestry Offices mentioned using the information services provided directly by DOE.

\subsubsection{Membership in Solar-Interested Organizations}

Seven of the 9 Biomass State Forestry Office Representatives interviewed were members of a professional, technical, or other organization with an interest in solar energy. These organizations (and the number of times mentioned) included:

- American Society for Public Administration,

- Forest Products Research Society, 
- New Jersey Forestry Association,

- Oklahoma Forestry Association,

- Society of American Foresters (5),

- Soil Conservation Society of America,

- Soil Council of America, and

- Stockton State College (Pomona, NJ).

Also mentioned were some organizations which could not be verified by the authors. These included "Illinois Tech. of Forestry," "International Agricultural Society," "Renewable Resources, Inc. (Kansas)," and "SAS."

Of the organizations mentioned above, membership in the Society of American Foresters was also mentioned by 5 of the 9 (56\%) Biomass Private Foresters.

\subsubsection{Exposure to Publications on Solar Rnergy}

During the past 6 months, 8 of the 9 Biomass State Forestry Office Representatives had read publications which included information on biomass energy. The publications they could specify (and the number of times mentioned) included:

- American Forests;

- Chemical Engineering;

- Dartmouth College Research Policy Center reports;

- Energy Resources of N.J., County by County, (CES, May 1979);

- Energy Future, (book, Harvard Business School);

- Home Energy Digest;

- Journal of Forestry;

- The Quad (newsletter, U.S. Forest Service);

- Princeton University, Center for Energy Studies, publications;

- Soil and Water Conservation Journal;

- Solid Waste Management;

- U.S. Forest Service publications (2); and

- Virginia Polytechnic Institute research papers.

Also mentioned were some publications which could not be verified by the authors. These included "trade magazines" (2), "Aware Newsletter," "York Shipley articles," and the Federal Government.

\subsubsection{Use of Special Acquisition Methods}

The respondents were asked whether they had obtained any information (not just biomass or solar energy) in the past year by computer terminal, by Computer Output Microform 
(COM), or by other microform (e.g., microfiche, microfilm sheets or rolls). Few Biomass State Forestry Office Representatives appeared accustomed to using these special acquisition methods, a trait also common to Biomass Private Foresters and Biomass Forest Products Engineers/Consultants. In the past year, 2 of the 9 (22\%) had used a computer terminal, 2 of the 9 had used COM, and 4 of the 9 (44\%) had used other microform. A comparison of Biomass State Forestry Office Representatives with Biomass Private Foresters and Biomass Forest Products Engineers/Consultants showed no statistically significant differences in the proportions using computer terminals, COM, or other microform.

\subsection{SUMMARY AND COMMENTS}

Nine respondents representing State Forestry Offices were interviewed. Five specifically mentioned that they were arranging for the supply of wood for fuel (two to area residents, one to electric utilities, and one to a university steam power system). Other biomass related activities included: data collection, volume estimates on timber, maintaining inventories on wood stoves and wood-fired boilers, providing marketing assistance to wood manufacturing industries, plantation production of wood fuel (including research and demonstration), combining wood with urban waste for fuel, and identifying available resources related to forestry.

The level of involvement of Biomass State Forestry Office Representatives was significantly $(P<0.05)$ higher than that of Biomass Private Foresters and slightly higher than that of Biomass Forest Products Engineers/Consultants. Their level of informedness, however, was slightly lower than that of Biomass Forest Products Engineers/ Consultants. Educationally, Biomass State Forestry Office Representatives more closely resembled Biomass Private Foresters in the type and level of degree earned. Both groups received slightly more advanced degrees (predominantly in forestry) compared to the Biomass Forest Products Engineers/Consultants ( with more concentration on degrees in engineering). Professionally, all three groups appeared to be highly experienced, with eight of the nine Biomass State Forestry Office Representatives and a minimum of $75 \%$ in the other two groups having over 10 years of experience in their current profession.

Biomass State Forestry Office Representatives gave the highest priority to receiving information on:

- The state of the art in biomass energy systems;

- Biomass energy system research in progress;

- Expected major developments in biomass energy applications during the next 10 years;

- Lists of technical experts. for biomass energy systems;

- Costs of installing and operating a biomass energy system compared to a conventional system;

- Institutional, social, environmental, and legal aspects of biomass energy applications; and

- Tax credits, grants, or other economic incentitives for biomass energy applications. 
They gave low ratings to "solar energy programs, research . . . outside of United States," "computer models," "calendars," "manual methods,"and "a nontechnical description."

Biomass State Forestry Office Representatives placed the highest priority on keeping up to date on the changing status of biomass energy. They were also interested in research results and in institutional issues. They were one of the few groups in the entire study interested in "lists of technical experts."

Biomass State Forestry Office Representatives most often received solar information from a wide variety of sources including "periodicals," DOE, "radio and TV," "some other state or local government office," USDA, "workshops, (etc.)," "an organizational ... library," GPO, "state energy or solar offices," and the Wood Energy Institute. Since the respondents were from state offices, it was not surprising to find them mentioning DOE significantly more of ten than did either Biomass Private Foresters or Biomass Forest Products Engineers/Consultants. None of the Biomass State Forestry Office Representatives were members of a solar energy association; four were members of the Society of American Foresters. 


\section{SE기}




\section{SECTION 6.0}

\section{BIOMASS PRIVATE FORESTERS}

\subsection{DESCRIPTION OF RESPONDENTS}

\subsubsection{Description of Sample}

This section describes the results of a telephone study to determine the needs of private (nongovernment) foresters, forest managers, and silviculturists for information on biomass energy systems. Nine Biomass Private Foresters were interviewed.

The sample frame for Biomass Private Foresters was constructed from the 1979 Directory of the Forest Products Industry [6]. A total of 64 individual nongovernmentaffiliated foresters' names were found, but names were eliminated where there was more than one name per state. After all adjustments were made, the 9 interview candidates were randomly selected from a sample frame of 40 names.

Respondents. In making the telephone calls to contact the randomly selected interview candidates, it sometimes occurred that the person could not be reached. In this event another randomly selected name was substituted for the original name. When individuals were contacted, it was verified that they really were foresters, and that they would be needing information on biomass energy within the next year. If they were not both foresters and needing information, they were asked if they could refer the interviewer to someone else in their organization who would be an appropriate respondent. If such a referral was made, a call was then made to this new candidate; if no intraorganizational referral was made, a new candidate was randomly selected from the sample frame. The results of this process may be seen in Table 6-1.

Table 6-1. COMPLETION OF INTERVIEWS: BIOMASS PRIVATE PORESTERS

Interview completed with sample frame candidate

Interview completed with referral candidate

Refusal or candidate termination

Contact attempted: could not reach candidate within three attempts

or before interviews were completed

Subtotal

Contact attempted: invalid candidate (e.g.,inappropriate

field of interest, no telephone)

TOTAL

Sample frame error rate r $^{\mathbf{a}}$ (Percent)

anvalid candidates divided by TOTAL

${ }^{b}$ Completed interviews divided by Subtotal 
Comparisons. For additional insight into the information needs and the information habits of these Biomass Private Foresters, results from this group are compared to the results from Biomass State Forestry Office Representatives and Biomass Forest Products Engineers/Consultants interviewed in this study. The data for Biomass Private Foresters, Biomass State Forestry Office Representatives, and Biomass Forest Products Engineers/ Consultants can be found in Appendix F.

\subsubsection{Current Status of Respondents}

Role. Seven of the 9 Biomass Private Foresters were consultants. Of the remaining 2 respondents, 1 was involved in logging and managing vegetation and the other was looking for markets which could convert his employer's sawmill by-products into energy. Of the 7 consultants, 3 were involved with production and collection of wood and 4 were involved with the conversion of wood waste to energy. The types of energy and uses of the energy produced (or planned to produce) from biomass conversion included electricity, building heating, drying (of wood), wood pellets, and gasohol.

Involvement. Only 1 of the 9 (11\%) Biomass Private Foresters said that he/she was "very involved" in biomass energy. However, another 6 (67\%) were "moderately involved." Comparatively, the Biomass State Forestry Office Representatives stated a significantly $(P<0.05)$ higher level of involvement (6 of the 9 or $67 \%$ "very involved") with Biomass Forest Products Engineers/Consultants rated slightly higher (4 of the 8 or $50 \%$ "very involved").

Informedness. Only 2 of the 9 (22\%) Biomass Private Foresters considered themselves "very informed"; however, 6 of the 9 (67\%) were "moderately informed." Comparatively, 4 of the 9 (44\%) Biomass State Forestry Office Representatives considered themselves "very informed" and 3 of the 9 (33\%) "moderately informed." Of the Biomass Forest Products Engineers/Consultants, 6 of the 8 (75\%) considered themselves "very informed" and 1 of the 8 (13\%) "moderately informed." The levels of informedness stated by the three groups did not differ significantly.

Need for Information. All 9 Biomass Private Foresters, all 9 Biomass State Forestry Office Representatives, and 7 of the 8 Biomass Forest Products Engineers/Consultants indicated they would need information on biomass energy on the job during the next year. Six of the 9 (67\%) Biomass Private Foresters also expected to need information on biomass energy off the job. This was similar to the results for Biomass State Forestry Office Representatives and Biomass Forest Products Engineers/Consultants, where 5 of the $9(56 \%)$ and 5 of the $8(63 \%)$ respectively indicated they would need biomass information outside the job.

\subsubsection{Background of Respondents}

Four of the 9 Biomass Private Foresters held master's degrees and 5 held bachelor's degrees. All 9 had received degrees in forestry or forest management. Degrees in forestry were also prevalent in the Biomass State Forestry Office group (6 of the 9 respondents). In contrast, only 1 respondent in the Biomass Forest Products Engineers/ Consultants groups had a degree in forestry, while 4 of the 8 had degrees in engineering. Two Biomass Private Foresters received their most recent degree over 40 years ago, 5 approximately 30 years ago, and 2 from 10-15 years ago. The dates of degrees received by this group appeared similar to those of Biomass State Forestry Office Representatives and Biomass Forest Products Engineers/Consultants. A comparison of level of education, 
however, showed Biomass State Forestry Office Representatives to have the highest proportion of advanced degrees and Biomass Forest Products Engineers/Consultants to have the lowest proportion.

All 9 respondents had been in their current profession for over 10 years, a level of experience similar to that of the other two groups of biomass foresters/engineers/consultants studied. All 9 of the Biomass Private Foresters stated they were foresters, with 7 of the 9 also stating that they were consultants.

\subsection{INPORMATION NEEDS OF RESPONDENTS}

\subsubsection{Technical Areas}

Biomass Private Foresters were asked to choose those areas in which they were "particularly interested in obtaining information" from a list of selected technical areas of biomass energy (see Table 6-2). They were more interested in "commercial or industrial burning of biomass" and "burnable pellets, etc.," than in "liquid fuels from biomass."

Table 6-2. AREA OF INTEREST: BIOMASS PRIVATE FORESTERS, BIOMASS STATE FORESTRY OFFICE REPRESENTATIVES, AND BIOMASS FOREST PRODUCTS ENGINEERS/CONSULTANTS

\begin{tabular}{|c|c|c|c|c|c|c|}
\hline \multirow[t]{2}{*}{ Technical Area of Interest } & \multicolumn{2}{|c|}{$\begin{array}{c}\text { Biomass } \\
\text { Private } \\
\text { Foresters }\end{array}$} & \multicolumn{2}{|c|}{$\begin{array}{c}\text { Biomass } \\
\text { State } \\
\text { Forestry } \\
\text { Office } \\
\text { Representatives }\end{array}$} & \multicolumn{2}{|c|}{$\begin{array}{l}\text { Biomass } \\
\text { Forest } \\
\text { Products } \\
\text { Engineers/ } \\
\text { Consultants }\end{array}$} \\
\hline & No. & Percent & No. & Percent & No. & Percent \\
\hline \multicolumn{7}{|l|}{ Commercial or Industrial Burning } \\
\hline Burnable Pellets, etc., from Biomass & 7 & 78 & $\begin{array}{l}y \\
8\end{array}$ & $\begin{array}{r}100 \\
89\end{array}$ & 6 & $\begin{array}{l}88 \\
75\end{array}$ \\
\hline Growth or Collection of Biomass Materials & 6 & 67 & 8 & 89 & 5 & 63 \\
\hline Gases from Biomass Materials & 3 & 33 & 7 & 78 & 5 & 63 \\
\hline Residential Burning of Wood & 3 & 33 & 8 & 89 & 4 & 50 \\
\hline Liquid Fuels from Biomass Materials & 2 & 22 & 7 & 78 & 5 & 63 \\
\hline
\end{tabular}

\subsubsection{Types of Information}

Biomass Private Foresters were asked to name the information about biomass energy that was important for them to obtain. All 9 Biomass Private Foresters volunteered one or more items of information that they considered important. Topics volunteered included information on: "sound" economic information, data on pyrolysis gas energy, production plant plans for small-scale conversion of sawmill waste ("to something like presto logs"), lists of forest residues which can be converted to pellet form, and the potential uses and projected yields from biomass conversion. Topics also mentioned that related to other technical areas of solar energy included: more (general) data on solar energy, wind generation, and solar cells for generating electricity. 
Four of the 9 Biomass Private Foresters volunteered they needed but were unable to get information on: state of the art in biomass energy, new harvesting techniques available for short rotation energy plantations, a "solid economic analysis" on biomass energy, the recovery of a pyrolysis gas system (similar to that used in automotive engines and for electricity generation in World War II), and a small-scale biomass energy conversion plan.

Choice Between Specific Needs. A list of 11 types of biomass energy information products and 12 types of biomass energy information categories was read to each respondent. Each respondent described the usefulness of each particular item by assigning it a value of "essential," "very useful," "somewhat useful," or "not at all useful." The results are given in Fig. 6-1. For the purpose of comparison, the results for Biomass State Forestry Office Representatives and Biomass Forest Products Engineers/Consultants may be found in Figs. 5-1 and 7-1, respectively.

Biomass Private Foresters selected the cost information categories as most important by a considerable margin. The seven top-rated information categories/products were:

- Costs of installing and operating a biomass energy system compared to a conventional system;

- Costs and performance of biomass systems;

- System diagrams and schematics;

- Expected major developments during the next 10 years;

- The state of the art;

- Tax credits, grants, or other economic incentives; and

- A technical description of how a particular system works.

Biomass Private Foresters assigned the lowest relative ratings to:

- Local building codes or other regulations;

- Computer models for sizing and predicting performance or costs;

- Standards, specifications, or certification programs;

- Solar energy programs, research, industries, and markets outside the United States;

- A bibliography of general readings; and

- Calendars of conferences and programs.

Statistical tests indicated all seven top categories/products were rated significantly $(P<0.05)$ higher than were the six lowest-rated items.

It should be noted that these lower-rated items were not necessarily of no worth to the Biomass Private Foresters. For example, 2 of the 9 (22\%) thought "computer models" were "very useful." Thus, these information categories/products could be useful to some Biomass Private Foresters, but were of a lower relative priority to the entire group.

Statistical tests were also used to determine whether the Biomass Private Foresters rated any of these information items significantly higher (or lower) than they were rated by the Biomass State Forestry Office Representatives and Biomass Forest Products 
Question \#8. I will read a list of potential information or information products on solar systems. For each, please tell me how useful that information would be to you. Would the following be: essential, very useful, somewhat useful, or not at all useful?

\begin{tabular}{|c|c|c|c|c|c|c|c|c|c|c|c|c|}
\hline \multirow{2}{*}{$\begin{array}{l}\text { Type of intormation } \\
\text { or intormation Producl. }\end{array}$} & \multirow[t]{2}{*}{$\ddot{R}$ ank } & \multicolumn{7}{|c|}{ Average UsefuIness $\cdots$} & \multicolumn{4}{|c|}{ Number of Responses } \\
\hline & & 1.0 & 1.5 & 2.0 & 2.5 & 3.0 & 3.5 & 4.0 & $\begin{array}{l}\text { Esren- } \\
\text { that } \\
\text { (4) }\end{array}$ & $\begin{array}{c}\text { very } \\
\text { vutulul } \\
\text { (3) }\end{array}$ & $\begin{array}{c}\text { mate } \\
\text { usetus } \\
\text { (2) }\end{array}$ & $\begin{array}{l}\text { atall } \\
\text { unatul } \\
\text { (11) }\end{array}$ \\
\hline Information Categories: & & & & & & & & 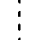 & & & & \\
\hline $\begin{array}{l}\text { Research Information Categories: } \\
\text { The state of the ant }\end{array}$ & 5 & & & & & & & & 2 & 1 & 4 & 2 \\
\hline Research in progress & 15 & & & & & & & & 0 & 2 & 4 & 3 \\
\hline Cost Information Categories: & & & & & & & & & & & & \\
\hline $\begin{array}{l}\text { Costs of installing and opcrating } \\
\text { a solar system compared to a } \\
\text { conventional system }\end{array}$ & 2 & & & & & & & & 3 & 3 & 2 & 1 \\
\hline $\begin{array}{l}\text { Custs and performance of } \\
\text { systems }\end{array}$ & 1 & & & & & & & & 3 & 3 & 3 & 0 \\
\hline Site-Specific Intormation Categories: & & & & & & & & & & & & \\
\hline $\begin{array}{l}\text { Local building codes or other } \\
\text { regulations affecting siting or } \\
\text { installation of systems }\end{array}$ & 22 & & & & & ! & & & 0 & 0 & 4 & 5 \\
\hline $\begin{array}{l}\text { Chimatological dala such as wind. } \\
\text { wealher. or amount of sunshine }\end{array}$ & 8 & & & & & & . & & 1 & 2 & 4 & 2 \\
\hline Marketing Information Categories: & & & & & & & & & & & & \\
\hline $\begin{array}{l}\text { Marketing statistics and sales } \\
\text { projections }\end{array}$ & NA & & & & & & & & NA & NA & NA & NA \\
\hline $\begin{array}{l}\text { Intormation on how to market and } \\
\text { sell systems including guidelines } \\
\text { on obtaining financial support }\end{array}$ & NA & & & & & & & & NA & NA & NA & NA \\
\hline $\begin{array}{l}\text { Other Information Categories: } \\
\text { Educational institutions and other } \\
\text { organtizations offering related courses } \\
\text { on system design or apolication }\end{array}$ & 11 & & & & & & & & 1 & 1 & 5 & 2 \\
\hline $\begin{array}{l}\text { Standards. specilications. or certifi- } \\
\text { cation programs for equipment }\end{array}$ & 20 & & & & & & & & 0 & 0 & 5 & 4 \\
\hline $\begin{array}{l}\text { Institutional. social. environ- } \\
\text { mental. and legal aspects of } \\
\text { sysiem applications }\end{array}$ & 17 & & & & & & & & 1 & 0 & 4 & 4 \\
\hline $\begin{array}{l}\text { Expected major developments } \\
\text { during the ncxt } 10 \text { ycars }\end{array}$ & 4 & & & & & $\vdots$ & & & 1 & 3 & 4 & 1 \\
\hline $\begin{array}{l}\text { Solar system programs, research. } \\
\text { industries, and markets outside } \\
\text { the United States }\end{array}$ & 20 & & & & & 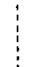 & & & 1 & 0 & 2 & 6 \\
\hline $\begin{array}{l}\text { Tax credits. grants. or other } \\
\text { economic incentives }\end{array}$ & 5 & & & & & $\vdots$ & & & 1 & 3 & 3 & 2 \\
\hline Information Products: & & & & & & & & & & & & \\
\hline$\frac{\text { Aeterence Information Products: }}{\text { A hihlingranhy al general readings }}$ & 18 & & & & & ' & & & 0 & 1 & 4 & 4 \\
\hline $\begin{array}{l}\text { A calendar of conferences and } \\
\text { programs }\end{array}$ & 18 & & & & & & & & 0 & 1 & 4 & 4 \\
\hline A lisi ul surices lú infurinaliónis & O & & & & & & $i$ & & 0 & 3 & 5 & 1 \\
\hline A list of tecnnical experts & 8 & & & & & 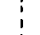 & & & 1 & 2 & 4 & 2 \\
\hline $\begin{array}{l}\text { Lists of local lenders, insurers. } \\
\text { builders. engineers. installers. } \\
\text { manufacturers, or distributors. }\end{array}$ & 11 & & & & & & & & 0 & 3 & 4 & 2 \\
\hline Deseriptive Information Products: & & & & & & & & & & & & \\
\hline $\begin{array}{l}\text { A non-technical description of how } \\
\text { a particular system works }\end{array}$ & 13 & & & & & & & & 0 & 3 & 3 & 3 \\
\hline $\begin{array}{l}\text { A technical description of how } \\
\text { a particular system works }\end{array}$ & 5 & & & & & & & & 1 & 3 & 3 & 2 \\
\hline System liaylanis un sulieinalics & 3 & & & & & & & & 1 & 5 & 1 & $?$ \\
\hline Design Intormation Products: & & & & & & & & & & & & \\
\hline $\begin{array}{l}\text { System design handbooks. installation } \\
\text { handbooks. or reference tables }\end{array}$ & 13 & & & & & & 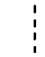 & & 0 & 3 & 3 & 3 \\
\hline $\begin{array}{l}\text { Manual methods for sizing and pre- } \\
\text { dicting the engineering performance } \\
\text { or llfe cycle costs of systems }\end{array}$ & 16 & & & & & & & & 1 & 1 & 2 & 4 \\
\hline $\begin{array}{l}\text { Curmpulter models for sizing and pre- } \\
\text { dicting the engineering performance } \\
\text { or life cycle costs of systems }\end{array}$ & 22 & & & & & 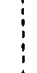 & 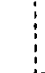 & : & 0 & 2 & 0 & 7 \\
\hline
\end{tabular}

Each sample trame of users was questioned on intormation and information products in the context of their specific technology. For example. biomass sample trames were asked about "a bibliography of general readings on biomiass". "a calendar of upcoming biomass conterences and programs ". etc.

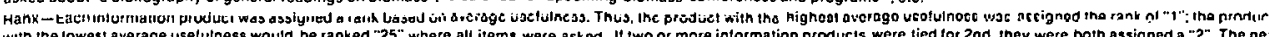
with the lowest av a ge uselulness would be ranked 25 " where an hems were asked. If iwo or more intormation products were tied for 2 nd. they were both assigned a " 2 ". The nea

.. Average usetulness was calculated by assigning the responses on a 1.4 scale trom a "4" tor "essential" "o o "1" lor "not very useful".

Figure 6-1. Usefulness of Selected Information Items: Biomass Private Foresters 
Engineers/Consultants. Some groups, however, tended to give higher scores in general than did other groups. To compensate for this effect, these statistical tests compared the "relative rating" given by one group to the "relative rating" given by the other groups. The procedure for calculating the relative rating is described in Appendix $\mathrm{E}$. The average overall rating Biomass Private Foresters gave to all items was the lowest of the three groups at 2.08, with Biomass State Forestry Office Representatives at 2.48, and Biomass Forest Products Engineers/Consultants, 2.63.

Statistical tests indicated that, compared to Biomass State Forestry Office Representatives, Biomass Private Foresters rated the need for information on "local building codes" significantly $(P<0.05)$ lower and also appeared to rate both cost and descriptive information higher.

Biomass Private Foresters also gave significantly $(P<0.05)$ higher ratings to "educational institutions," and significantly $(\mathrm{P}<0.05)$ lower ratings to "standards, specifications" and "manual methods" than did the Biomass Forest Products Engineers/Consultants group. There was also evidence that the Biomass Private Foresters placed a higher priority on "lists of technical experts" and "expected major developments."

\subsection{ACQUSITION OF INPORMATION BY RESPONDENTS}

\subsubsection{Use of Selected Information Sources}

Biomass Private Foresters were asked which of 21 different potential sources of solar information they had used in the past few years. For this question the respondents were not asked if they had obtained information on biomass energy, but instead were asked if they had obtained any solar information from each specific source. Thus, the question sought to determine which information sources were the most familiar to the respondents. The results are shown in Fig. 6-2. For the purpose of comparison, the results for Biomass State Forestry Office Representatives and Biomass Forest Products Engineers/ Consultants may be found in Figs. 5-2 and 7-2, respectively.

The information sources mentioned most of ten by Biomass Private Foresters were:

- Periodicals, newspapers, or magazines;

- Some other state or local government office or publications; and

- U.S. Department of Agriculture (USDA), including Extension and Forestry.

The information sources mentioned least of ten by Biomass Private Foresters were:

- Solar Energy Industries Association (SEIA);

- Technical Information Center (TIC);

- International Solar Energy Society (ISES);

- A commercial data base;

- National Technical Information Service (NTIS);

- National Solar Heating and Cooling Information Center (NSHCIC);

- Regional Solar Energy Centers (RSECs); 
Question \#11. In the past few years, have you obtained any type of solar information from any of the following sources?

Information Sources

Public Media:

Radio or TV

Periodicals. newspapers or magazines

Private Solar-Involved Organizations:

Private solar energy or environmental organizations

The local chapter or national headquarters of International Solar Energy Socıety (ISES). Including their publications

The local chapter or national headquarters of Solar Energy Industries Association (SEIA), including their publıcations Contacts with Professionals:

An installer, builder. designer or manufacturer of solar systems

Workshops. conferenccs or training sessions

Information Services*:

Yout. organızational library of a local library

A commercial data base: for example. Lockheed. SDC. BRS

Smithsonian Srienre Information Fxchange (SSIE)

A Federal library or information center: tor example. the National Agricultural Library or the Environmental Data System

The Government Printing Office (GPO)

National Technical Information Service (NTIS)

Technical Information Center at Oak Ridge. (TIC)

Government Solar-Involved Organizations

Directly from the U.S. Department of Energy

National Solar Heating \& Cooling Information Center

Regional Solar Energy Centers

State Energy or Solar Offices

\section{Other:}

Some other state or local government office or publication

A public utility company

Sources for this specific sample frame*":

USDA, including Extension and Forestry

Bio-Energy Council

State Department of Agriculture
Percentage Responding Yes $\cdots$

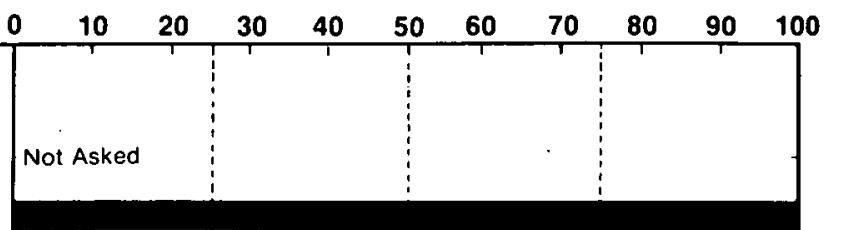

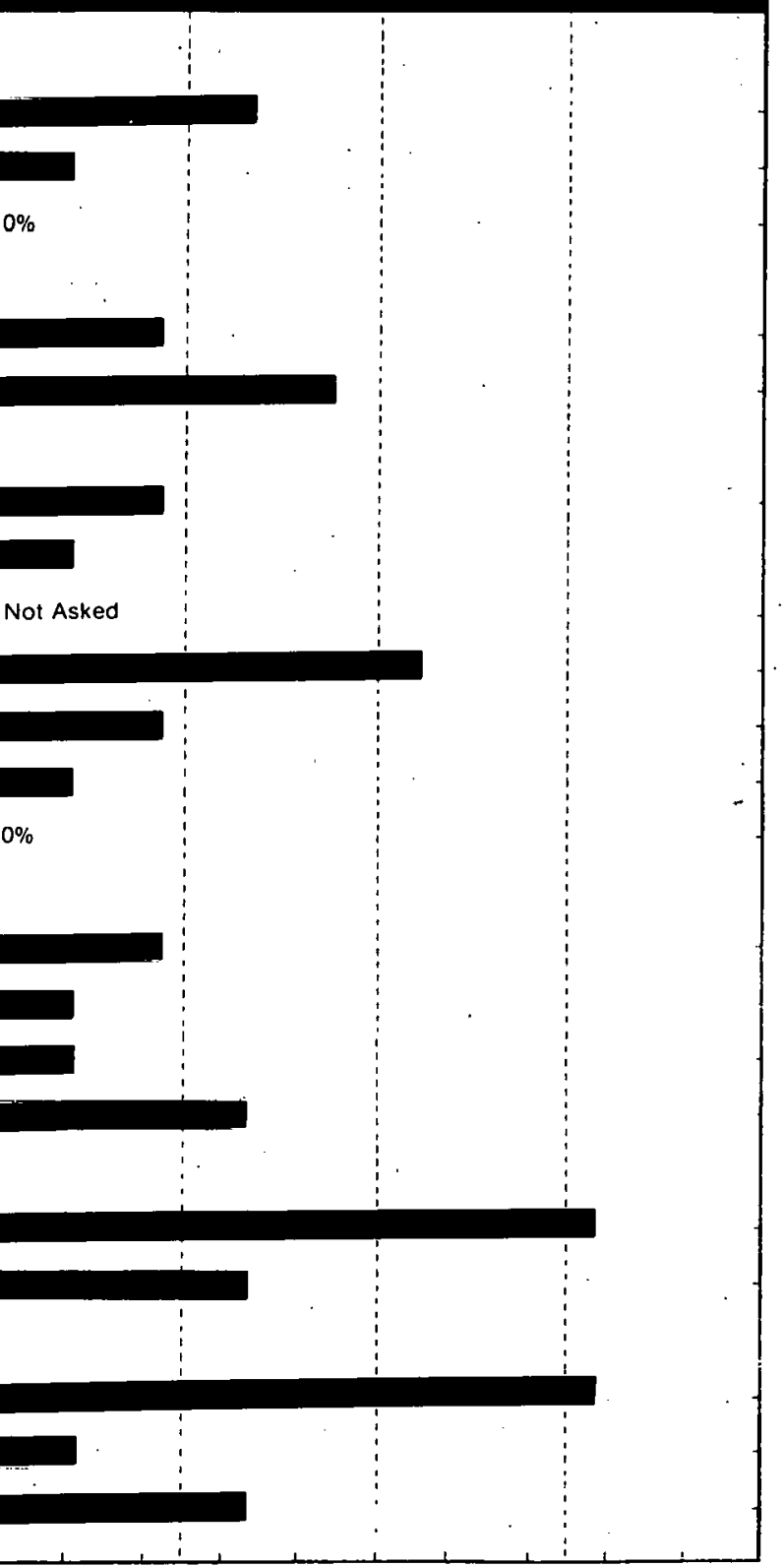

- Services and centers whose primary purpose is to disscminatc information.

Some sample frames were questioned about additional information sources which are applicable to their technology. For example. the manufacturers of biomass conversion equipment were also asked it they have obtained any type of solar information irom: "the local or national office of the U.S. Department of Agriculture. including Extension and Forestry."

-. I hese data are basen upon a inial of 9 respundeils.

Figure 6-2. Use of Selected Information Sources: Biomass Private Foresters 
- Bio-Energy Council;

- An installer, builder, designer, or manufacturer;

- An organizational library or a local library;

- The Government Printing Office (GPO);

- Directly from the U.S. Department of Energy (DOE); and

- State Departments of Agriculture.

In each of these cases a maximum of 2 respondents had used the source.

In comparing the information sources used by Biomass Private Foresters to those used by Biomass State Forestry Office Representatives and Biomass Forest Products Engineers/ Consultants, significantly $(P<0.05)$ more State representatives had used DOE. Of the three biomass groups studied, the Biomass Private Foresters mentioned using the least number of information sources and Biomass State Forestry Office Representatives mentioned the most number of sources. Only 4 of the 21 (19\%) sources were mentioned by half or more of the Private Foresters group, compared to 14 of the 23 (61\%) sources for Biomass State Forestry Office Representatives and 11 of the $22(50 \%)$ sources for Biomass Forest Products Engineers/Consultants. Of all the 86 groups studied, Biomass Private Foresters were in the bottom seven in terms of familiarity with the information sources listed.

\subsubsection{Membership in Solar-Interested Organizations}

Six of the 9 Biomass Private Foresters interviewed were members of a professional, technical, or other organization with an interest in solar energy. These organizations (and the number of times mentioned) included:

- American Congress on Surveying and Mapping,

- American Forest Institute,

- American Forestry Association (AFA) (2),

- American Society of Photogrammetry,

- Forest Products Research Society,

- New York Forest Association,

- Northeastern Loggers Association, and

- Society of Americen Foresters (SAF) (5).

\subsubsection{Exposure to Publications on Solar Energy}

During the past 6 months, all 9 Biomass Private Foresters had read publications that included information on biomass energy. The publications they could specify (and the number of times. mentioned) included:

- American Forests Magazine;

- Forest Products Journal (Forest Products Research Society); 
- Georgia Research Division of Forestry commission paper \#4 on using dirty wood chips for energy;

- Journal of Forestry (3);

- Northern Logger and Timber Processer;

- Pulp and Paper; and

- Wood Energy Institute publications.

Also mentioned were some publications which the authors could not verify. These included "elementary materials," "Forest Industry Magazine (2)," "Lumbering Journal," "Woodburning," "Wood Digest," and "trade journals."

\subsubsection{Use of Special Acquisition Methods}

The respondents were asked whether they had obtained any information (not just biomass or solar energy) in the past year by computer terminal, by Computer Output Microform (COM), or by other microform (e.g., microfiche, microfilm sheets or rolls). Few Biomass Private Foresters appeared accustomed to using these special acquisition methods, a trait also common to Biomass State Forestry Office Representatives and Biomass Forest Products Engineers/Consultants. In the past year, only 1 of the 9 (11\%) had used.a computer terminal, none had used COM, and 1 (11\%) had used other microform. A comparison of Biomass Private Foresters with Biomass State Forestry Office Representatives and Biomass Forest Products Engineers/Consultants showed no statistically significant differences in the proportion using computer terminals, COM, or other microform.

\subsection{SUMMARY AND COMMENTS}

Nine Biomass nongovernment-affiliated foresters were interviewed. Seven of the nine were consultants, one was involved in logging and managing vegetation and the other was looking for markets which would convert their sawmill by-products into energy. Of the seven consultants, three were involved with production and collection of wood and four with the process of conversion of wood waste to energy (including generating electricity, heating a building, drying of wood, wood pellets, and gasohol).

The level of involvement and the degree of informedness of Biomass Private Foresters was lower than those of Biomass State Forestry Office Representatives and Biomass Forest Products Engineers/Consultants. Educationally, Biomass Private Foresters resembled the Biomass State Forestry Office Representatives in the type and level of degree earned. Both groups had received slightly more advanced degrees (predominantly in forestry) than had the Biomass Forest Products Engineers/Consultants (with slightly fewer advanced degrees and more concentration on degrees in engineering).

Professionally, all three groups appeared to be highly experienced, with all nine Biomass Private Foresters and a minimum of $75 \%$ in the other two groups having over 10 years of experience in their current profession.

Biomass Private Foresters gave the highest priority to receiving information on:

- Costs of installing and operating a biomass energy system compared to a conventional system; 
- Costs and performance of biomass energy installations;

- Biomass processing system diagrams and schematics;

- Expected major developments in biomass energy applications during the next 10 years;

- The state of the art in biomass energy systems;

- Tax credits, grants, or other economic incentives for biomass energy applications; and

- A technical description of how a particular biomass energy system works.

They gave low ratings to "local building codes," "computer models," "standards, specifications," "solar energy programs, research, . . . outside the United States," "a bibliography of general readings," and "calendars of conferences and programs."

The Biomass Private Forester group received solar information most of ten through "periodicals," "some other state or local government office or publications," and USDA. None of the Biomass Private Foresters were members of a solar energy association and very few obtained any information through traditional solar energy or DOE sources. Six of the nine (67\%) were members of SAF. 


\section{SECTION 7.0}

\section{BIOMASS FOREST PRODUCTS ENGINEERS/CONSULTANTS}

\subsection{DESCRIPTION OF RESPONDENTS}

\subsubsection{Description of Sample}

This section describes the results of a telephone study to determine the needs of forest products engineers and consultants for information on biomass energy system. Eight Biomass Forest Products Engineers/Consultants were interviewed.

The sample frame for Biomass Forest Products Engineers/Consultants was constructed from the 1979 Directory of Suppliers, Manuf acturers, Technical Consultants, Professional Engineers put out by the Forest Products Research Society [4]. Contact names were listed under the section headed "Technical Consultants and Professional Engineers." These included industries, engineering companies, universities, U.S. Department of Agriculture (USDA), Tennessee Valley Authority (TVA), and private consultants. Duplicates with sample frames for Biomass State Forestry Office Representatives, Biomass Private Foresters, Biomass Manufacturers, and any other professionally related groups were eliminated. After all adjustments were made, the 8 interview candidates were randomly selected from a sample frame of 83 names.

Respondents. In making the telephone calls to contact the randomly selected interview candidates, it sometimes occurred that the person could not be reached. In this event another randomly selected name was substituted for the original name. When individuals were contacted, it was verified that they really were forest products engineers or consultants, and that they would be needing information on biomass energy within the next year. If they were not both forest products engineers/consultants and needing information, they were asked if they could refer the interviewer to someone else in their organization who would be an appropriate respondent. If such a referral was made, a call was then made to this new candidate; if no intraorganizational referral was made, a new candidate was randomly selected from the sample frame. The results of this process may be seen in Table $7-1$.

Comparisons. For additional insight into the information needs and the information habits of these Biomass Forest Products Engineers/Consultants, results from this group are compared to the results from Biomass Private Foresters and Biomass State Forestry Office Representatives interviewed in this study. The data for Biomass Forest Products Engineers/Consultants, Biomass Private Foresters, and Biomass State Forestry Office Representatives can be found in Appendix F.

\subsubsection{Current Status of Respondents}

Role. By technical area, 6 of the 8 Biomass Forest Products Engineers/Consultants had expertise in conversion and 2 in production and collection. Of the 6 conversion experts, 5 consulted on complete systems or plant design and 1 consulted on wood-fired boilers. The 2 production and collection experts consulted on the handling and transporting of biomass and 1 also consulted on the cost of harvesting and estimating yields per acre. 
Table 7-1. COMPLETION OF INTERVIRWS: BIOMASS FOREST PRODUCTS ENGINEERS/CONSULTANTS

Event

Number of

Candidates

Interview completed with sample frame candidate

Interview completed with referral candidate

Refusal or candidate termination

Contact attempted: could not reach candidate within three attempts

or before interviews were completed

Subtotal

Contact attempted: invalid candidate (e.g., inappropriate

field of interest, no telephone)

TOTAI.

Sample frame error rate ${ }^{a}$ (Percent)

Completion rate ${ }^{\mathrm{b}}$ (Percent)

$a_{\text {Invalid candidates divided by TOTAL }}$

$\mathrm{b}_{\text {Completed interviews divided by Subtotal }}$

Involvement. Four of the 8 (50\%) Biomass Forest Products Engineers/Consultants said that they were "very involved" (2 of the 8 or $25 \%$ were "moderately involved") in biomass energy. This level of involvement was higher than that of the Biomass Private Foresters with 1 or $11 \%$ "very involved" (6 of the 8 or 6796 "moderately involved") and similar to that of the Biomass Forestry Office Representatives with 6 of the 8 or $67 \%$ "very involved" ( 0 "moderately involved").

Informedness. Six of the 8 (75\%) Biomass Forest Products Engineers/Consultants considered themselves "very informed" and 1 of 8 (13\%) was "moderately informed." Comparatively, only 2 of the 9 (22\%) Biomass Private Foresters considered themselves "very informed." However, 6 of the 9 (67\%) were "moderately informed." Of the Biomass State Forestry Office Representatives, 4 of the 9 (44\%) stated "very informed" and 3 of the 9 (33\%), "moderately informed." The levels of informedness stated by the three groups did not differ significantly.

Need for Information. Seven of the 8 (88\%) Biomass Forest Products Engineers/ Consultants indicated they would need information on biomass energy on the job during the next year. Five of the 8 (63\%) Biomass Forest Products Engineers/Consultants also expected to need information on biomass energy off the job. This was similar to the results for Biomass Private Foresters and Biomass State Forestry Office Representatives, where 6 of the 9 (67\%) and 5 of the 9 (56\%), respectively, indicated they would need biomass information outside the job.

\subsubsection{Background of Respondents}

Five of the 8 Biomass Forest Products Engineers/Consultants held bachelor's degrees, 2 held master's degrees, and 1 had received vocational/technical training. Four had received degrees in engineering, and 1 each in chemistry, forestry, and business administration. Three Biomass Forest Products Engineers/Consultants received their most 
recent degree over 35 years ago, 2 were received 20-30 years ago, 1 was received 10-20 years ago, and 1 was received 5-10 years ago. The dates of degrees received by this group appeared similar to those of Biomass Private Foresters and Biomass State Forestry Office Representatives. A comparison of the educational levels, however, showed Biomass State Forestry Office Representatives to have the highest proportion of advanced degrees and Biomass Forest Products Engineers/Consultants to have the lowest proportion.

One Engineer/Consultant had been in his/her current profession for less than 2 years, 1 for 6-10 years, and the other 6 respondents for over 10 years-a level of experience similar to the other two groups of biomass foresters/engineers studied. Four of the 8 stated their current profession as engineers; including a consulting engineer, an engineer contractor and a chemical engineer. Of the remaining 4, 1 was a consultant in the wood fuel industry, 1 was a manager, and 2 did not specify their profession.

\subsection{INPORMATION NEEDS OF RESPONDENTS}

\subsubsection{Technical Areas}

Biomass Forest Products Engineers/Consultants were asked to choose those areas in which they were "particularly interested in obtaining information" from a list of selected technical areas of biomass energy (see Table 7-2). They seemed to be more interested in "commercial or industrial burning of biomass" than in "residential burning of wood." For the other technical areas, both Biomass Forest Products Engineers/Consultants and Biomass Private Foresters appeared to have somewhat less interest in "liquid fuels from biomass materials" and "residential burning of wood" than did the Biomass State Forestry Office Representatives.

Table 7-2. AREAS OF INTEREST: BIOMASS FOREST PRODUCTS ENGINEERS/CONSULTANTS, BIOMASS STATE FORESTRY OFFICE REPRESENTATIVES, AND BIOMASS PRIVATE PORESTERS

\begin{tabular}{|c|c|c|c|c|c|c|}
\hline \multirow[t]{2}{*}{ Technical Area of Interest } & \multicolumn{2}{|c|}{$\begin{array}{l}\text { Biomass } \\
\text { Forest } \\
\text { Products } \\
\text { Engineers/ } \\
\text { Consultants }\end{array}$} & \multicolumn{2}{|c|}{$\begin{array}{c}\text { Biomass } \\
\text { State } \\
\text { Forestry } \\
\text { Office } \\
\text { Representatives }\end{array}$} & \multicolumn{2}{|c|}{$\begin{array}{c}\text { Biomass } \\
\text { Private } \\
\text { Foresters }\end{array}$} \\
\hline & No. & Percent & No. & Percent & No. & Percent \\
\hline \multicolumn{7}{|l|}{ Commercial or Industrial } \\
\hline Burning of Biomass & 7 & 88 & 9 & 100 & 7 & 78 \\
\hline \multicolumn{7}{|l|}{ Burnable Pellets, etc., from } \\
\hline Biomass & 6 & 75 & 8 & 89 & 7 & 78 \\
\hline Growth or Collection of & & & & & & \\
\hline Biomass Materials & 5 & 63 & 8 & 89 & 6 & 67 \\
\hline $\begin{array}{l}\text { Gases from Biomass Materials } \\
\text { quid Fuels from Biomass }\end{array}$ & 5 & 63 & 7 & 78 & 3 & 33 \\
\hline Materials & 5 & 63 & 7 & 78 & 2 & 22 \\
\hline Residential Burning of Wood & 4 & 50 & 8 & 89 & 3 & 33 \\
\hline
\end{tabular}




\subsubsection{Types of Information}

Biomass Forest Products Engineers/Consultants were asked to name information about biomass energy that was important for them to obtain. Seven of the 8 Biomass Forest Products Engineers/Consultants volunteered one or more items of information that they considered important. Topics volunteered included information on: new technology, actual experiences with pilot projects, pollution standards for biomass conversion plants and the actual cost per ton, U.S. Forest Service estimates of biomass availability, technical descriptions of biomass systems, forecasts of changes in legal aspects of biomass, information on the total delivery system of biomass from production to end use, information on burning of sewage sludge, use of agricultural by-products and waste (i.e., whey from cheese), transportation costs per ton for wood pulp and sawdust, the burning characteristics of wood, and information on new business and new boilers to be developed.

Four of the 8 Biomass Forest Products Engineers/Consultants volunteered that they needed, but were unable to get, information on U.S. Forest Service estimates of biomass availablility (2), actual operating experiences (both problems and successes) on plants currently in service (from an independent third party), the ability of plants to meet pollution guidelines, marketing data, lists of experts, and engineering data.

Choice Between Specific Needs. A list of 11 types of biomass energy information products and 14 types of biomass energy information categories was read to each respondent. Each respondent described the usefulness of each particular item by assigning it a value of "essential," "very useful," "somewhat useful," or "not at all useful." The results are given in Fig. 7-1. For the purpose of comparison, the results for Biomass State Forestry Office Representatives and Biomass Private Foresters may be found in Figs. 5-1 and $6-1$, respectively.

Biomass Forest Products Engineers/Consultants selected the cost information categories as most important. The five top-rated information categories/products were:

- Costs and performance of systems,

- Manual methods for sizing and predicting performance or costs,

- Costs of installing and operating a biomass energy system compared to a conventional system,

- A technical description of how a particular system works, and

- System diagrams or schematics.

Biomass Forest Products Engineers/Consultants assigned the lowest relative ratings to:

- Educational institutions and other organizations offering courses,

- How to market and sell solar systems,

- Calendars of conferences and programs, and

- A bibliography of general readings.

Statistical tests indicated all four of the top categories/products were rated significantly $(P<0.05)$ higher than were the four lowest-rated items. 
ㅍ.

rer

Question \#8. I will read a list of potential information or information products on solar systems. For each, please tell me how useful that information would be to you. Would the following be: essential, very useful, somewhat useful, or not at all useful?

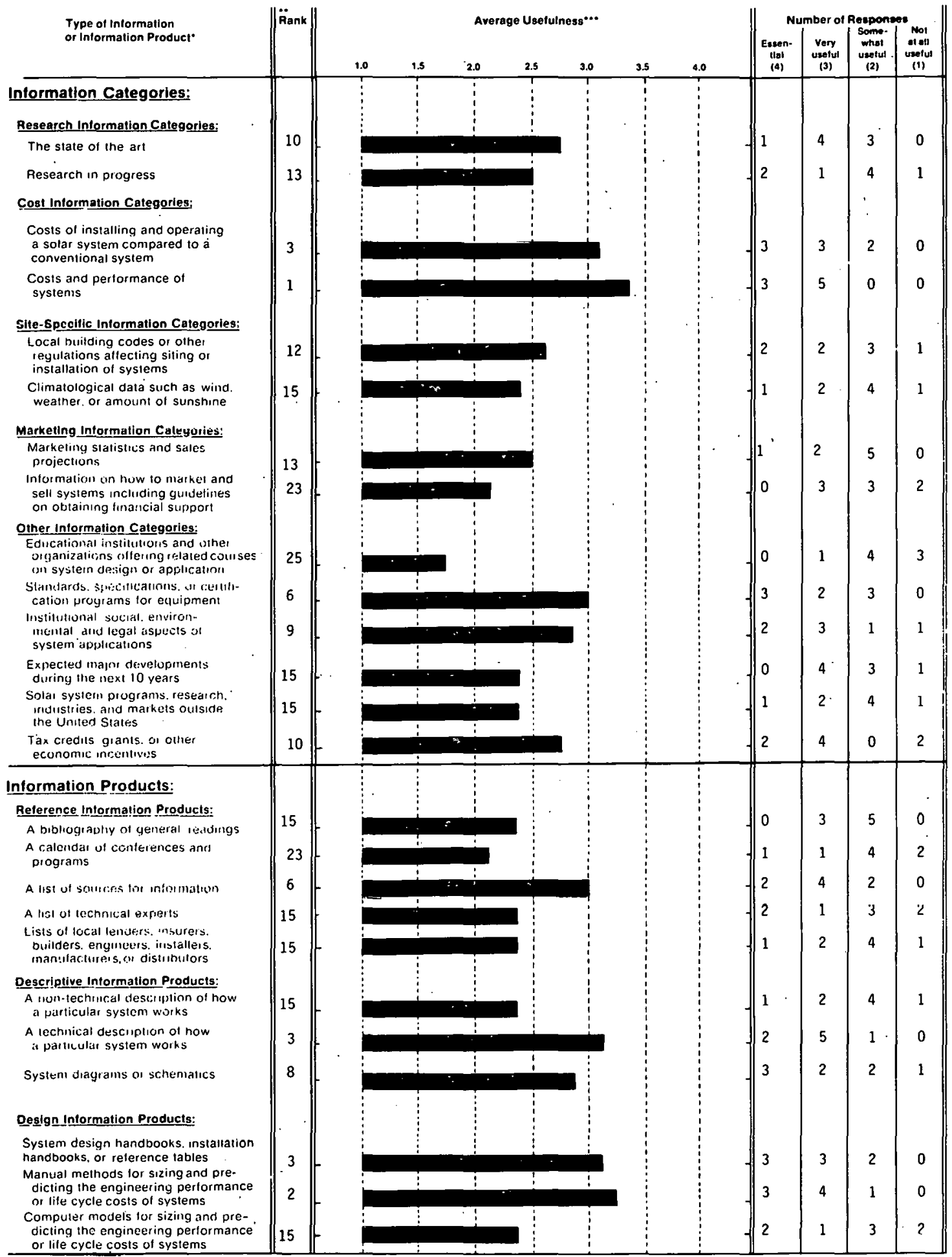
Eacn sample lrame of users was questioned on intormstion and inlormation products in the context of their specific lechnology. For example. biomass sample itames were
ashed aboul "a bibliography of general readings on biomass"." 8 calendar ol upcoming biomass conterences and programs ".etc. "Pank--Each inlormation producl was assigned a rank based on average uselulness. Thus, Ihe product with the highest average uselulness was assigned the rank of " 1 ", Ine product

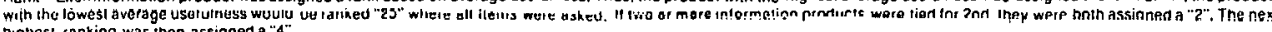

-.. Average usefulness was calculated by assigning the responses on a $1-4$ scale trom a "4" tor "essential" to a " 1 " lor "not very useful".

Figure 7-1. Usefulness of Selected Information Items: Biomass Forest Products Englneers/Cuirsullaints 
It should be noted that these lower-rated items were not necessarily of no worth to the Biomass Forest Products Engineers/Consultants. For example, 3 of the 8 (38\%) thought "a bibliography of general readings" was "very useful." Thus, these information categories/products could be useful to some Biomass Forest Products Engineers/ Consultants, but were of a lower relative priority to the entire group.

Statistical tests were also used to determine whether the Biomass Forest Products Engineers/Consultants rated any of these information items significantly higher (or lower) than they were rated by the Biomass Private Foresters and the Biomass State Forestry Office Representatives. Some groups, however, tended to give higher scores in general than did other groups. To compensate for this effect, these statistical tests compared the "relative rating" given by one group to the "relative rating" given by the other groups. The procedure for calculating the relative rating is described in Appendix E. The average overall rating Biomass Forest Products Engineers/Consultants gave to all items was the highest of the three groups at 2.63; for Binmass Private Foresters it was 2.08; and for Biomass State Forestry Office Representatives it was 2.48.

Compared to Biomass State Forestry Office Representatives, the Biomass Forest Products Engineers/Consultants rated the need for information on "manual methods for sizing" and "solar energy programs, research . . . outside the United States" significantly $(P<0.05)$ higher, and "educational institutions" and "expected major developments" significantly $(\mathrm{P}<0.05)$ lower. Biomass Forest Products Engineers/Consultants also gave higher ratings to "cost and performance" and to "standards."

Compared to the Biomass Private Foresters group, Biomass Forest Products Engineers/ Consultants gave significantly $(\mathrm{P}<0.05)$ higher ratings for "standards, specifications" and "manual methods for sizing" and significantly $(\mathrm{P}<0.05)$ lower ratings for "educational institutions." Biomass Forest Products Engineers/Consultants were also much more interested in "system design handbooks."

\subsection{ACQUISITION OF NFORMATION BY RESPONDENTS}

\subsubsection{Use of Selected Information Sources}

Biomass Forest Products Engineers/Consultants were asked which of 22 different potential sources of solar information they had used in the past few years. For this question the respondents were not asked if they had obtained information on biomass energy, but instead were asked if they had obtained any solar information from each specific source. Thus, the question sought to determine which information sources were the most familiar to the respondents. The results are shown in Fig. 7-2. For the purpose of comparison, the results for Biomass State Forestry Office Representatives and Biomass Private Foresters may be found in Figs. 5-2 and 6-2, respectively.

The information sources mentioned most often by Biomass Forest Products Engineers/ Consultants were:

- Periodicals, newspapers, or magazines;

- An installer, builder, designer, or manufacturer (outside of your organization);

- Government Printing Office (GPO); 
Question \#11. In the past few years, have you obtained any type of solar information from any of the following sources?

Information Sources

Percentage Responding Yes $\cdots$

Public Media:

Radio or TV

Periodicals. newspapers or mayazınes

Private Solar-Involved Organizations:

Private solar energy or environmental organizations

The local chapter or national headquarters of International

Solar Energy Society (ISES). including their publications

The local chapter or national headquarters of Solar Energy

Industries Association (SEIA), including their publications

\section{Contacts with Protessionals :}

An installer. builder. designer or manufacturer of solar systems

Workshops. conferences or training sessions

Information Services:

Your organizational library or a local library

A commercial data base: for example. Lockheed, SDC, BRS

Smithsonian Science Information Exchange (SSIE)

A Federal library or information center: for example. the National

Agricultural Library or the Environmental Data System

The Government Printing Office (GPO)

National Technical Information Service (N TIS)

Technical Information Center at Oak Ridge (TIC)

Government Solar-Involved Organizations

Directly from the III.S Department of Energy

National Solar Heating \& Cooling Information Centeı

Regional Solar Energy Centers

State Energy or Solar Offires

Other:

Some other state or local government office or publication

A public utility company

Sources for this specific sample frame**:

USDA, including Extension and Forestry

Bio-Energy Council

Wood Energy Institute

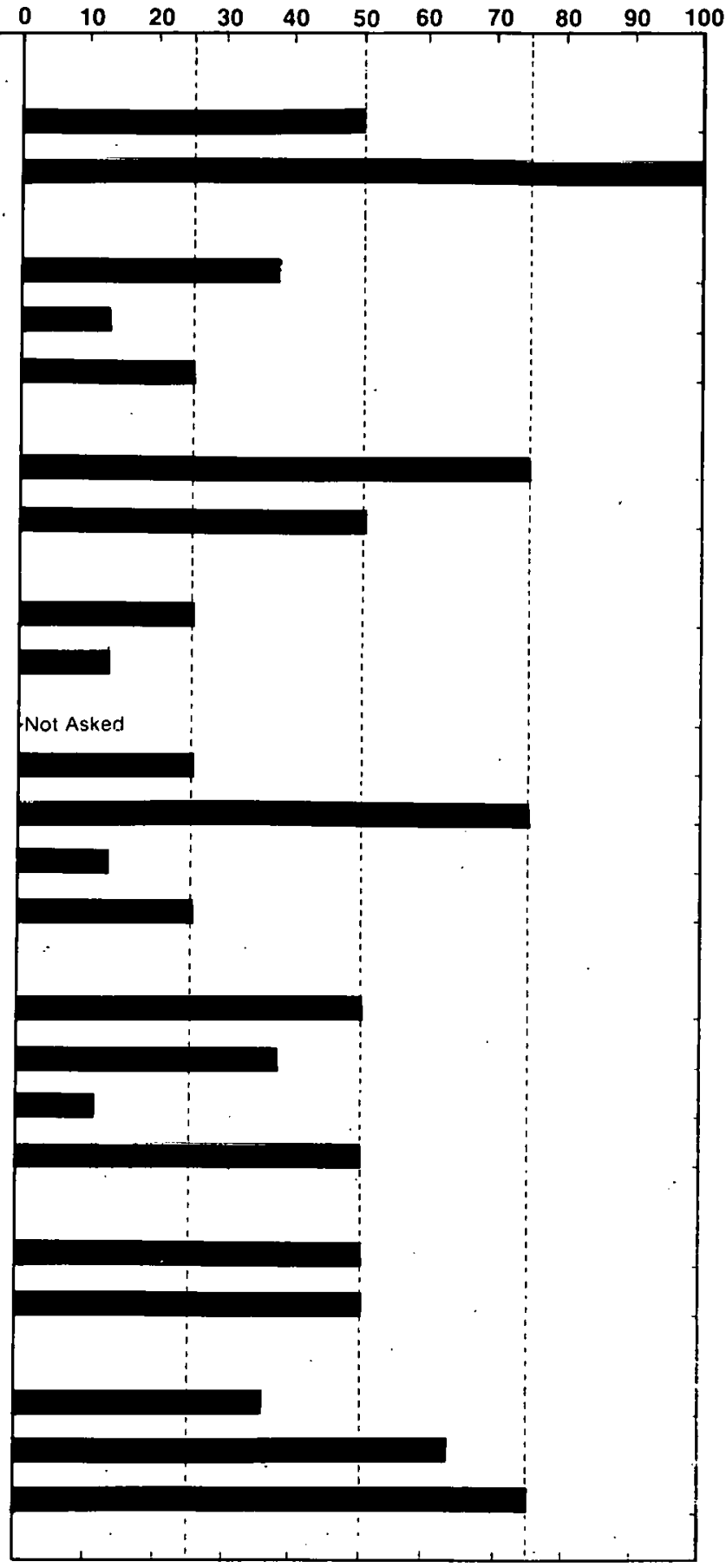

- Services and centers whose urimary puriuse is 10 disseminate information.

- Some sample frames were questioned about additional information sources which are applicable to their technology. For example. the manufacturers of biomass conversion equipment were also asked it they have obtained any type of solar intormation trom: "the local or national office of the U.S. Department of Agriculture. including Extension and Forestry.'

These vida die basied upon a total of 0 iesjojindeints.

Figure 7-2. Use of Selected Information Sources: Biomass Forest Products Engineers/Consultants 
- Wood Energy Institute; and

- The Bio-Energy Council.

The information sources mentioned least of ten by Biomass Forest Products Engineers/ Consultants were:

- International Solar Energy Society (ISES),

- A commercial data base;

- National Technical Information Service (NTIS),

- Regional Solar Energy Centers (RSECs),

- Solar Energy Industries Association (SEIA),

- An organizational library or a local library,

- A federal library or information center, and

- Technical Information Center (TIC).

In comparing the information sources used by Biomass Forest Products Engineers/ Consultants to those used by Biomass Private Foresters and Biomass State Forestry Office Representatives, significantly $(P<0.05)$ more representatives of the State Forestry Offices mentioned using the services provided by the Department of Energy (DOE).

\subsubsection{Membership in Solar-Interested Organizations}

Only 2 of the 8 Biomass Forest Products Engineers/Consultants interviewed were members of a professional, technical, or other organization with an interest in solar energy. 'l'hese organizations (all receiving single mentions) included:

- American Chemical Society (ACS);

- American Society of Agricultural Engineers;

- American Society of Heating, Refrigerating and Air Conditioning Engineers. ( $\Lambda$ SHR $\Lambda E)$;

- American Society of Mechanical Engineers (ASME);

- Forest Products Research Society;

- Institute of Electrical and Electronics Engineers;

- National Society of Professional Engineers; and

- Volunteers in Technical Assistance (VITA).

Also mentioned was "IES" (Institute of Environmental Sciences or Institute for Earth Sciences), an organization which the authors could not further specify. 


\subsubsection{Exposure to Publications on Solar Energy}

During the past 6 months, all 8 of the Biomass Forest Products Engineers/Consultants had read publications that included information on biomass energy. The publications they could specify (all receiving single mentions) included:

- Chemical and Engineering News,

- Chemical Technology,

- Combustion,

- Consumer Reports,

- Fortune,

- MIT technology reviews,

- National Waste News Magazine,

- Plant Engineering,

- Pollution,

- Popular Mechanies,

- Popular Science,

- Science,

- Solar Age,

- Solar Engineering,

- Solid Waste Management,

- Timber and Timber Products, and

- Wall Street Journal.

\subsubsection{Use of Special Acquisition Methods}

The respondents were asked whether they had obtained any information (not just biomass or solar energy) in the past year by computer terminal, by Computer Output Microform (COM), or by other microform (e.g., microfiche, microfilm sheets or rolls). Few Biomass Forest Products. Engineers/Consultants appeared accustomed to using these special acquisition methods, a trait also common to Biomass Private Foresters and Biomass State Forestry Office Representatives. In the past year, no one had used a computer terminal or COM, and only 2 of the 8 (25\%) had used other microform. A comparison of Biomass Forest Products Engineers/Consultants with Biomass Private Foresters and Biomass State Forestry Office Representatives showed no statistically significant differences in the proportion using computer terminals, COM, or other microform.

\subsection{SUMMARY AND COMMENTS}

Eight Biomass Forest Products Engineers/Consultants were interviewed. Six of the eight were experts in conversion and two in production and collection. Of those involved in conversion, five consulted on complete systems or plant design and one consulted on wood-fired boilers. The two production and collection experts consulted on the handling 
and transporting of biomass; one also consulted on the cost of harvesting and estimating yields per acre.

The level of involvement and degree of informedness of Biomass Forest Products Engineers/Consultants was slightly higher than that of Biomass Private Foresters but similar to that of Biomass State Forestry Office Representatives. Educationally, engineering degrees were predominant among the Biomass Forest Products Engineers/ Consultants, whereas both Biomass Private Foresters and Biomass State Forestry Office Representatives had higher concentrations of degrees in forestry. Of the three groups, Biomass Forest Products Engineers had the lowest proportion holding advanced degrees.

Biomass Forest Products Engineers/Consultants gave the highest priority to receiving information on:

- Costs and̄ performance of biomass energy systems,

- Manual methods for sizing and predicting performance or costs of biomass energy systems,

- Costs of installing and operating a biomass energy system compared to a conventional system,

- A technical description of how a particular biomass energy system works, and

- Biomass processing system diagrams or schematics.

They gave low ratings to "educational institutions," "how to market and sell solar systems," "calendars," and "a bibliography of general readings."

Biomass Forest Products Engineers/Consultants were most familiar with obtaining solar information through "periodicals," "an installer, builder, (etc.)," the GPO, the Wood Energy Institute, and the Bio-Energy Council: 
SECTION 8.0

BIOMASS EDUCATORS

\subsection{DESCRIPTION OF RESPONDENTS}

\subsubsection{Description of Sample}

This section describes the results of a telephone study to determine the needs of postsecondary educators for information on biomass energy systems. Nine Biomass Educators were interviewed.

The sample frame for Biomass Educators was constructed by searching the Solar Energy Information Data Base (SEIDB) Education Data Base [7]. Fifty-five schools listed courses which included biomass information and identified instructors for each course. Only instructors of supposedly advanced-level courses were used. Instructors who also appeared in education sample frames for other technologies were eliminated. In many cases course descriptions-named several technologies and it was necessary to make some arbitrary decisions about the sample in which to place the course instructor. Related Biomass Researcher and Engineer sample frames were also checked for duplicate names, and these were eliminated from the larger sample frame. After all adjustments were made, the 9 interview candidates were randomly selected from a sample frame of 32 names.

Respondents. In making the telephone calls to contact the randomly selected interview candidates, it sometimes occurred that the. person could not be reached. In this event another randomly selected name was substituted for the original name. When individuals were contacted it was verified that they really had been teaching biomass, and that they would be needing information on biomass energy within the next year. (No attempt was made to determine if the respondent was currently teaching a course on biomass energy.) If they were not both involved and needing information, they were asked if they could refer the interviewer to someone else in their organization who would be an appropriate respondent. If such a referral was made, a call was then made to this new candidate; if no intraorganizational referral was made, a new candidate was randomly selected from the sample frame. The results of this process may be seen in Table 8-1.

Comparisons. For additional insight into the information needs and the information habits of these Biomass Educators, results from this group are compared to the results from all of the educators interviewed in this study (All Educators). In addition to biomass, the technologies included in All Educators were: solar thermal electric power, active solar heating and cooling, passive solar heating and cooling, photovoltaics, wind, and industrial process heat. In performing any statistical comparisons, the totals for Biomass Educators have been subtracted from the totals for All Educators. The data for Biomass Educators and for All Educators can be found in Appendix F. 
Table 8-1. COMPLETION OF INTERVIEWS: BIOMASS EDUCATORS

Event

Number

of Candidates

Interview completed with sample frame candidate

8

Interview completed with referral candidate

Refusal or candidate termination

1

0

Contact attempted: could not reach candidate within three attempts,

or before interviews were completed

Subtotal

Contact attempted: invalid candidate (e.g., inappropriate field of Interesl, no (elephone)

TOTAL.

Sample frame error rate ${ }^{a}$ (Percent)

$a_{\text {Invalid candidates divided by TOTAL }}$

${ }^{\mathrm{b}}$ Completed interviews divided by Subtotal

\subsubsection{Current Status of Respondents}

Role. Seven of the 9 Biomass Educators were on the faculties of 4-year colleges or universities; the other 2 taught at 2-year colleges. Departments in which their courses were taught varied: 4 taught in science, engineering, or physics departments; 4 in environmental studies, resource science, or solar technology departments; and the other 1 in the technical education department. While all courses covered biomass conversion, the topics of alternate energy, energy conservation, and passive energy were also popular in the course curricula. Four of the courses were taught only at the graduate level, three were open to juniors and seniors, and three were courses for solar technicians, installers, and/or do-it-yourselfers. In describing what they were presently doing in the area of biomass energy, only 4 specifically mentioned teaching, and 1 research. Two were involved in the design and construction of biomass conversion equipment: a small-scale wood combustion furnace, a solar-heated alcohol still, and a methane generator. Topics included in their teaching included: heat recovery from decomposition, various ways to extract energy from biomass, horticulture and agriculture with an eye to biomass conversion, large-scale wood utilization for energy conversion, alternative energy, and smallscale agriculture and aquaculture.

Involvement. Three of the $9(33 \%)$ Biomass Educators said that they were "very involved" in biomass. This was slightly lower than the 27 of the 63 (43\%) of All Educators who said they were "very involved" in their respective technologies. However, the proportion who considered themselves at least "moderately involved". was the same for Biomass Educators (7 of the 9 or $78 \%$ ), as it was for All Educators.

Informedness. Only 2 of the 9 (22\%) Biomass Educators considered themselves "very informed," compared to 31 of the 63 (49\%) All Educators. Only one of the other six groups of Educators gave themselves as low marks for informedness as did the Biomass Educators. 
Need for Information. All respondents indicated they would need information on biomass energy on the job during the next year. Three of the 9 (33\%) Biomass Educators expected to need information on biomass outside the job as well.

\subsubsection{Background of Respondents}

Seven of the 9 (78\%) Biomass Educators held doctoral degrees. The remainder held bachelor's degrees. The percentage of Biomass Educators holding advanced degrees (beyond bachelor's) was slightly lower than was found for All Educators (89\%). Eight of the 9 Biomass Educators had received their most recent degree within the past 15 years, 4 of them within the past 5 years. Four of the Biomass Educators had degrees in physics, 2 each in mechanical engineering and education, and 1 in management.

Seven of the group gave their present profession as educator, instructor, professor, or teacher. Other professional descriptions were: expert in energy conversion systems and mechanical engineer. Only 1 respondent referred to solar energy in describing his/ her profession. Most (5) of the Biomass Educators had been in their present profession (not necessarily teaching) for over 10 years, 2 for 6-10 years, and 2 for 3-5 years.

\subsection{NPORMATION NEEDS OF RESPONDENTS}

\subsubsection{Technical Areas}

Biomass Educators were asked to choose those areas in which they were "particularly interested in obtaining information" from a list of selected technical areas of biomass energy. More than half of all respondents were interested in all six areas about which they were asked. All of the 9 were interested in "residential burning of wood"; 8 of the 9 (89\%) were interested in "gases from biomass materials." "Growth or collection of biomass materials" and "liquid fuels from biomass" each had 7 of the 9 (78\%) interested. Six of the $9(67 \%)$ were interested in "commercial or industrial burning of biomass," and 5 of the $9(56 \%)$ in "burnable pellets, etc., from biomass."

\subsubsection{Types of Information}

Biomass Educators were asked to name the information about biomass energy that was important for them to obtain. All of the 9 volunteered one or more items of information which they considered important. Included were: applications of biomass techniques, evaluation of different biomass energy sources, biological heat production, current development and commercialization activities, a "syllabus of current statistics," production techniques, types of biomass systems, methane and methanol production, corn and alcohol production, net energy yields, federal permission (licensing) for powering machinery with alcohol, biomass and electrical cogeneration, summary of research on smallscale agricultural biomass systems, safe chimney design, and "a broad spectrum of technical information."

Three of the 9 (33\%) Biomass Educators stated that there was information on blomass which they needed but were unable to get. Information that they needed but were unable to get included: standard weather conditions for local (rural) areas; technical system design aspects; landownership patterns (available wood, attitudes of landowners); and (for 
one respondent) all of the items which were considered "essential" in Fig. 8-1 below (this particular respondent classified 15 items as "essential").

Choice Between Specific Needs. A list of 11 types of biomass information products and 14 types of biomass information categories was read to each respondent. Each respondent described the usefulness of each particular item by assigning it a value of "essential," "very useful," "somewhat useful," or "not at all useful." The results are given in Fig. 8-1. For comparison, results for All Educators are in Fig. 8-2.

Research information items tended to receive high ratings as a class from Biomass Educators. The five top-rated information categories/products were:

- Climatological data,

- The state of the art,

- Research in progress,

- Costs of installing and operating a biomass energy system compared to a conventional system, and

- A bibliography of general readings.

Biomass Educators assigned the lowest relative ratings to:

- Solar energy programs, research, industries, and markets outside the U. S.;

- How to market and sell solar systems;

- Marketing statistics and sales projections;

- Tax credits, grants, or other economic incentives;

- Calendars of conferences and programs; and

- Lists of local lenders, insurers, builders, engineers, installers, manufacturers, or distributur's.

Statistical tests indicated that the ratings for the five top-rated information items were signficantly $(P<0.05)$ higher than those for the six lowest-rated items, except for the differences in ratings of "a bibliography" versus "tax credits" or "lists of local lenders, (ctc.)."

These results pictured the Biomass Educator as wanting information on research information, climate, and costs. This was one of the few Biomass groups placing a high value on climatological data.

It should be noted that these lower-rated items were not necessarily of no worth to the Biomass Educators. For example, 2 of the 9 (22\%) thought "tax credits" were "essential." Thus, these information categories/products could be useful to some Biomass Educators but were of a lower relative priority to the entire group.

Statistical tests were also used to determine whether the Biomass Educators rated any of these information items significantly higher (or lower) than they were rated by All Educators. Some groups, however, tended to give higher scores in general than did other groups. To compensate for this effect, these statistical tests compared the "relative rating" given by one group to the "relative rating" given by the other groups. The 
Question \#8. I will read a list of potential information or information products on solar systems. For each, please tell me how useful that information would be to you. Would the following be: essential, very useful, somewhat useful, or not at ail useful?

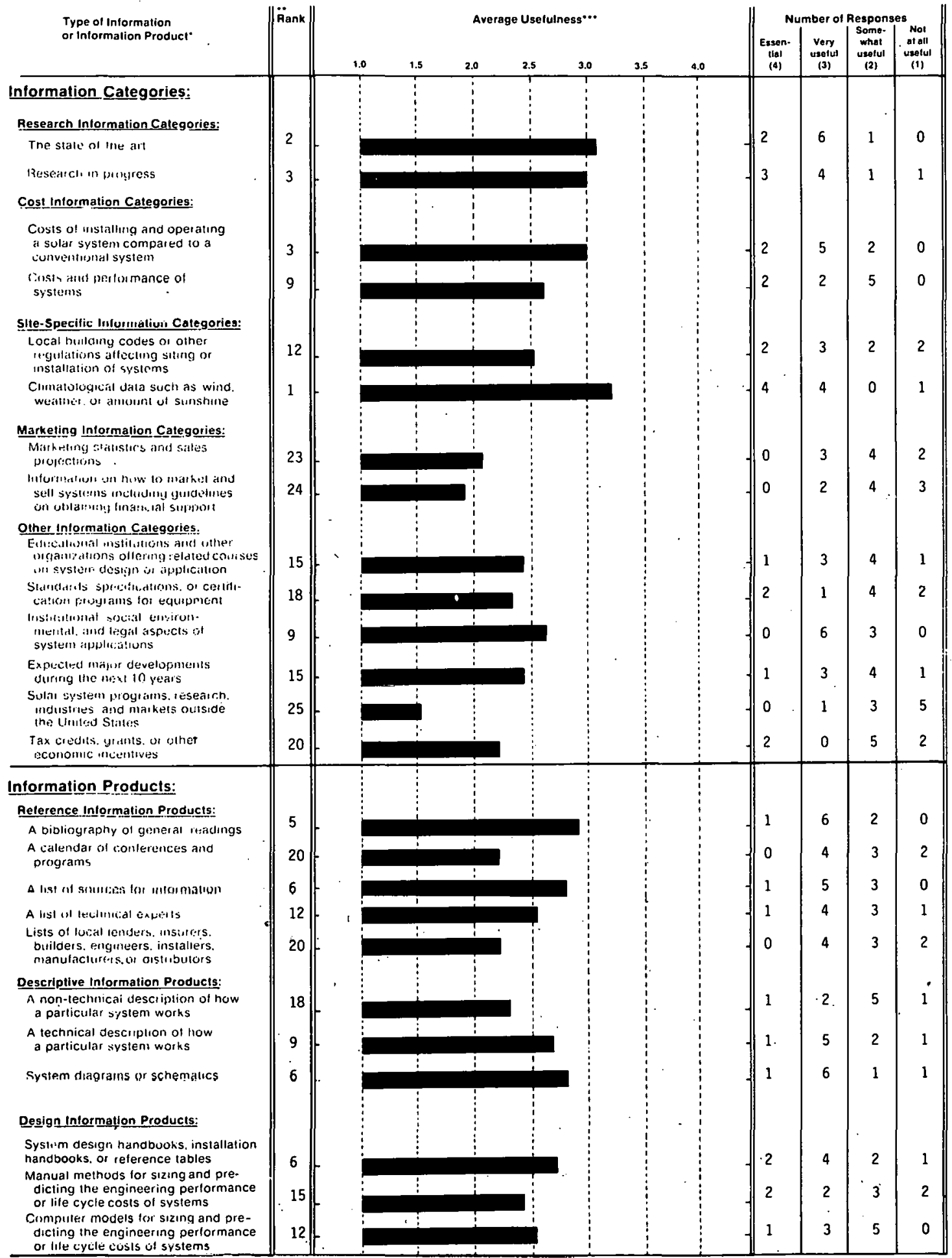
ing performance

Each sample frame of users was questioned on intormation and intormation products in the context of their specilic technology. For example. biomass sample trames were asked about "a bibloggraphy of general readings on biomass". "A calendar of upcoming biomast conterences and prograns ". orc Rank-Eachinformation producl was assigned a rank based on average uselulness. Thus, the product with ine highest average usetulness was assigned the rank of " 1 ; the producl

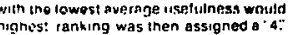

Avcrage usofulnoss was calculateo by as sioning the resnonses an a $1-4$ scale lrom a "4" lor "essential" 10 a "1" tor "nol very useful"

Figure 8-1. Usefulness of Selected Information Items: Biomass Educators 
Question \#8. I will read a list of potential information or information products on solar systems. For each, please lell me how useful that information would be to you. Would the following be: essential, very useful. somewhat useful, or not at all useful?

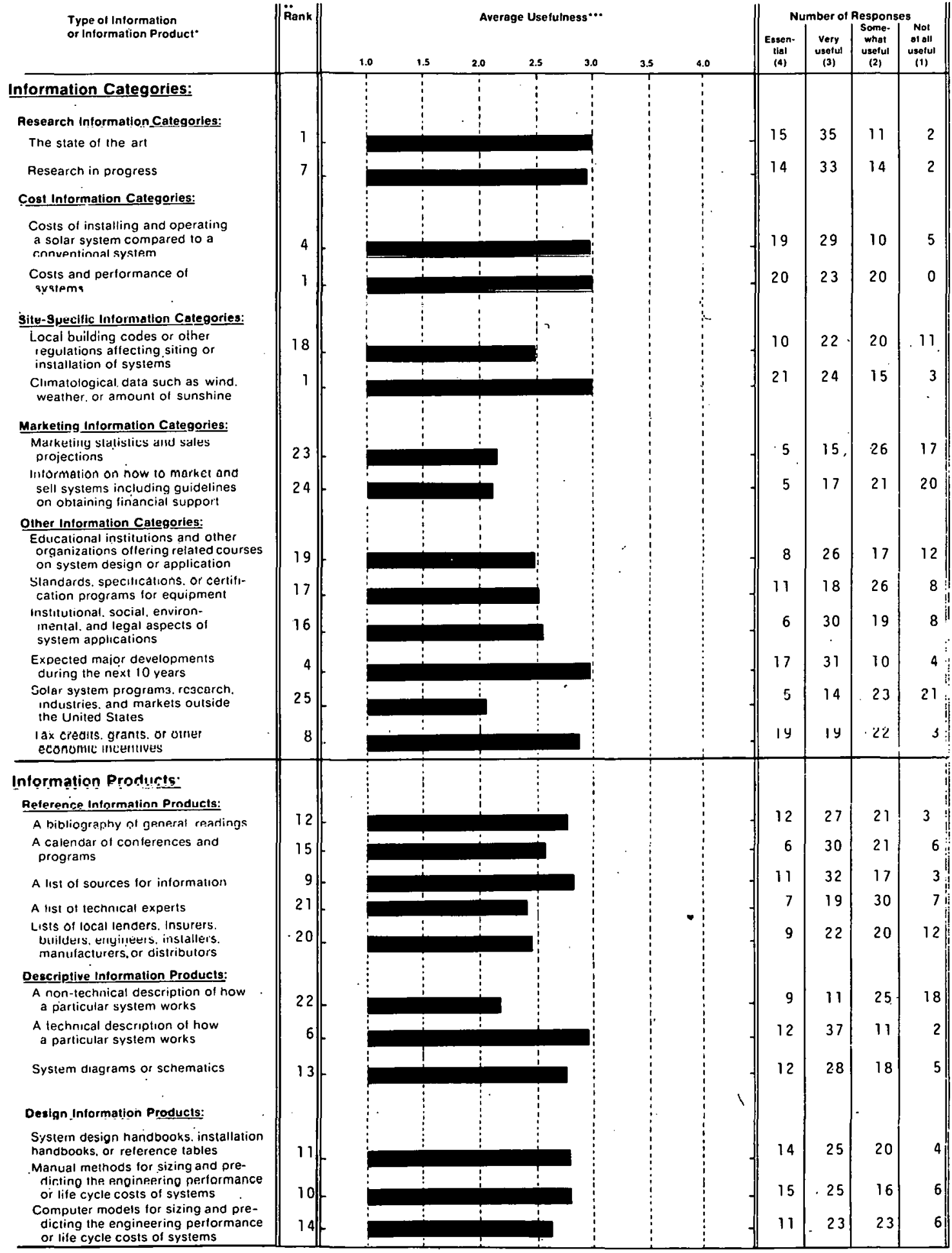

Each sample trame of users was questioned on intormation and information products in the context of their specilic teennology. For exampte. biomass sample irames were asked about "a bibliography ol general readings on biomass" "a calendar of upcoming biomass conterences and programs ", elc. with the lowest average usetulness would bo
inghest ranking was inen assinneo a -4 :

".. Average usetulness was calculated by assigning the responses on a 1.4 scale from a "4" tor "essentrat" to a "1" tor "not very usefu"

Figure 8-2. Usefulness of Selected Information Items: All Educators 
procedure for calculating the relative rating is described in Appendix E. The average overall rating Biomass Educators gave to all items was lower (2.54) than it was for All Educators (2.64).

In comparing the results for Biomass Educators to the results for All Educators, there were some dissimilarities. Only "climatological data," "the state of the art," and "costs of installing" were also among the five top-rated items for All Educators. All Educators concurred with lowest ratings for "solar energy programs . . . outside the U.S." and the two items in the marketing category. Statistical tests indicated that, compared to All Educators, the Biomass Educators rated "tax credits" and "expected major developments" significantly $(\mathrm{P}<0.05)$ lower. Biomass Educators also appeared to give higher ratings to "a bibliography," "lists of technical experts," "institutional . . . aspects," and "local building codes."

\subsection{ACQUISITION OF INFORMATION BY RESPONDENTS}

\subsubsection{Use of Selected Information Sources}

Biomass Educators were asked which of 22 different potential sources of solar information they had used in the past few years. For this question the respondents were not asked if they had obtained information about biomass energy, but instead were asked if they had obtained any solar information from each specific source. Thus, the question sought to determine which information sources were the most familiar to the respondents. The results for Biomass Educators are shown in Fig. 8-3. For comparison, those for All Educators are shown in Fig. 8-4.

The information sources mentioned most often by Biomass Educators (at least 8 of the 9 had used them) were:

- An installer, builder, designer, or manufacturer;

- The Government Printing Office (GPO);

- Periodicals, newspapers, or magazines;

- Private solar energy or environmental organizations;

- Workshops, conferences, or training sessions;

- An organizational library or a local library;

- State energy or solar offices; and

- U.S. Department of Agriculture (USDA).

The question did not distinguish between "workshops, conferences" attendance and proceedings. These first two sources listed above received unanimous positive responses from Biomass Educators. All but "private solar .... organizations" (and USDA, about which other Educators were not asked) had also been used by at least $80 \%$ of All Educators. A significantly $(P<0.05)$ greater proportion (7 of the 9 or $75 \%)$ of Biomass Educators than of All Educators (29 of the 63 or 46\%) had used National Solar Heating and Cooling Information Center (NSHCIC). 
Question \#11. In the past few years, have you obtained any type of solar information from any of the lollowing sources?

Information Sources

Public Media:
Radio or TV
Periodicals. newspapers or magazines
Private Solar-Involved Organizations:
Private solar energy or environmental organizations
The local chapter or national headquarters of International
Solar Energy Society (ISES). including their publications
The local chapter or national headquarters of Solar Energy
Industries Association (SEIA). including their publications
Contacts with Professionals:

An Installer. builder. designer or manufacturer of solar systems

Workshops. conferences or training sessions

Information Services*:

Your organizational library or a local library

A commercial data base: for example. Lockheed. SDC. BRS

Smithsonian Science Information Exchange (SSIE)

A Federal library or information center: for example. the National Agricultural Library or the Environmental Data System

The Government Printing Office (GPO)

National Technical Information Service (NTiS)

Technical Information Center at Oak Ridge (TIC)

\section{Government Solar-Involved Organizations}

Directly from the U.S. Department of Energy

National Solar Heating \& Cooling Information Center

Regional Solar Energy Centers

State Energy or Solar Offices

Other:

Some other state or local government office or publication

A public utility company

Sources for this specific sample frame**:

USDA, including Extension and Forestry

Bio-Energy Council
Percentage Responding Yes *.*

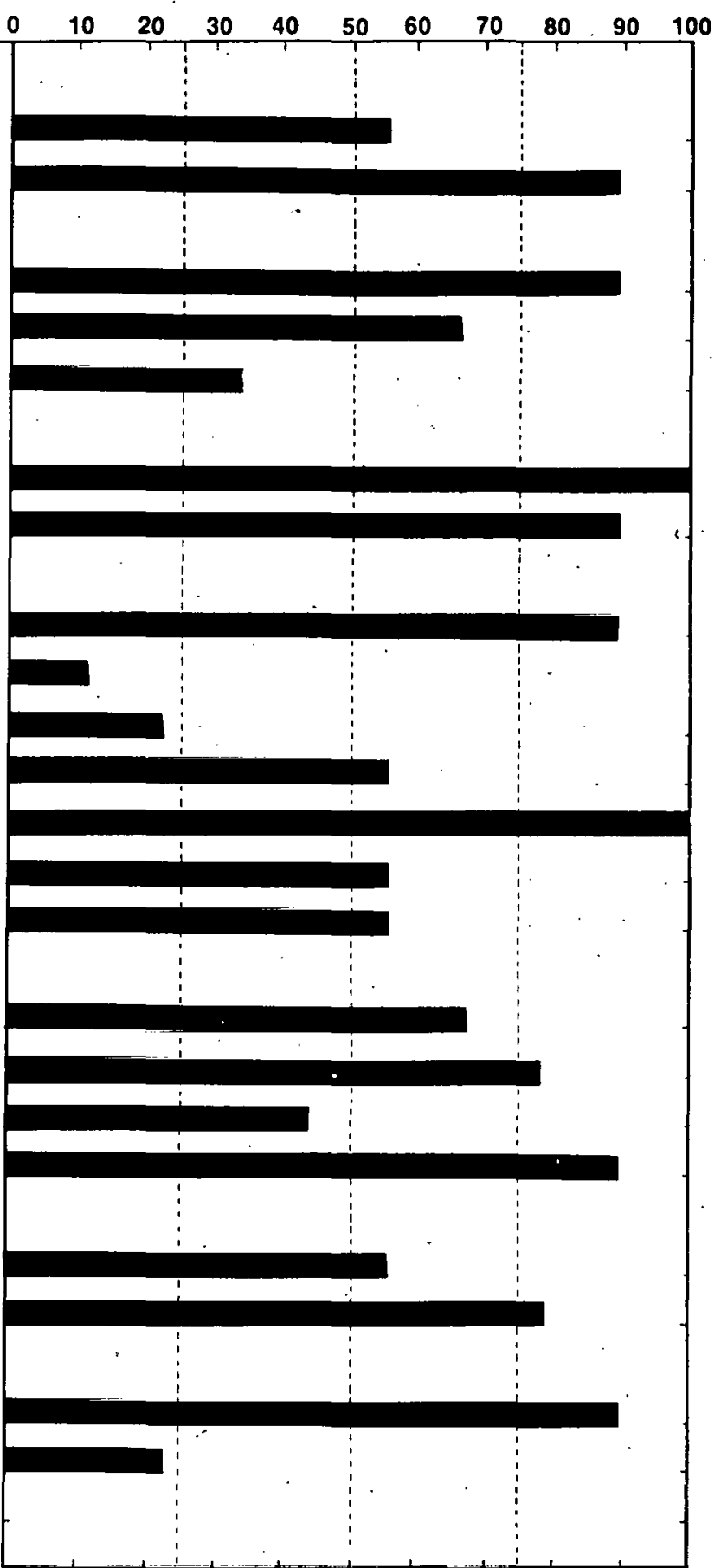

- Services and centers whose primary purpose is to disseminate information.

Some sample frames were questioned about additional information sources which are applicable to their technology. For example. the manufacturers of biomass conversion equipment were also asked if they have obtained any type of solar information from: "the local or national office of the U.S. Department of Agriculture. including Extension and Forestry."

*. These data are based upon a total of 9 respondents.

Figure 8-3. Use of Selected Information Sources: Biomass Educators 
Question \#11. In the past few years, have you oblained any type of solar information from any of the following sources?

Information Sources

Public Media:
Radio or TV
Periodicals. newspapers or magazınes

Private Solar-Involved Organizations:

Private solar energy or environmental organizations

The Incal chapter or national headquarters of International Solar Energy Society (ISES), including their publications

The local chapter or national headquarters of Solar Energy Industries Association (SEIA). including their publications

Confacts with Prolessionals:

An installer, builder, designer or manufacturer of solar systems

Workshops, conferences or training sessions

Information Services*:

Your organizational library or a local library

A commercial data base: for example. Lockheed. SDC. BRS

Smithsonian Science Information Exchangc (SSIE)

A Federal library or information center; for example. the National Agricultural Library or the Environmental Data System

The Government Printing Office (GPO)

National Technical/nformation Service (NTIS)

Technical Information Center at Oak Ridge (TIC)

Government Solar-Involved Organizations

Directly from the U.S. Department of Energy

National Solar. Heating \& Cooling Information Center

Regional Solar Energy Centers

State Energy or Solar Offices

Other:

Some other state or local government office or publication

A public utility company
Percentage Responding Yes *

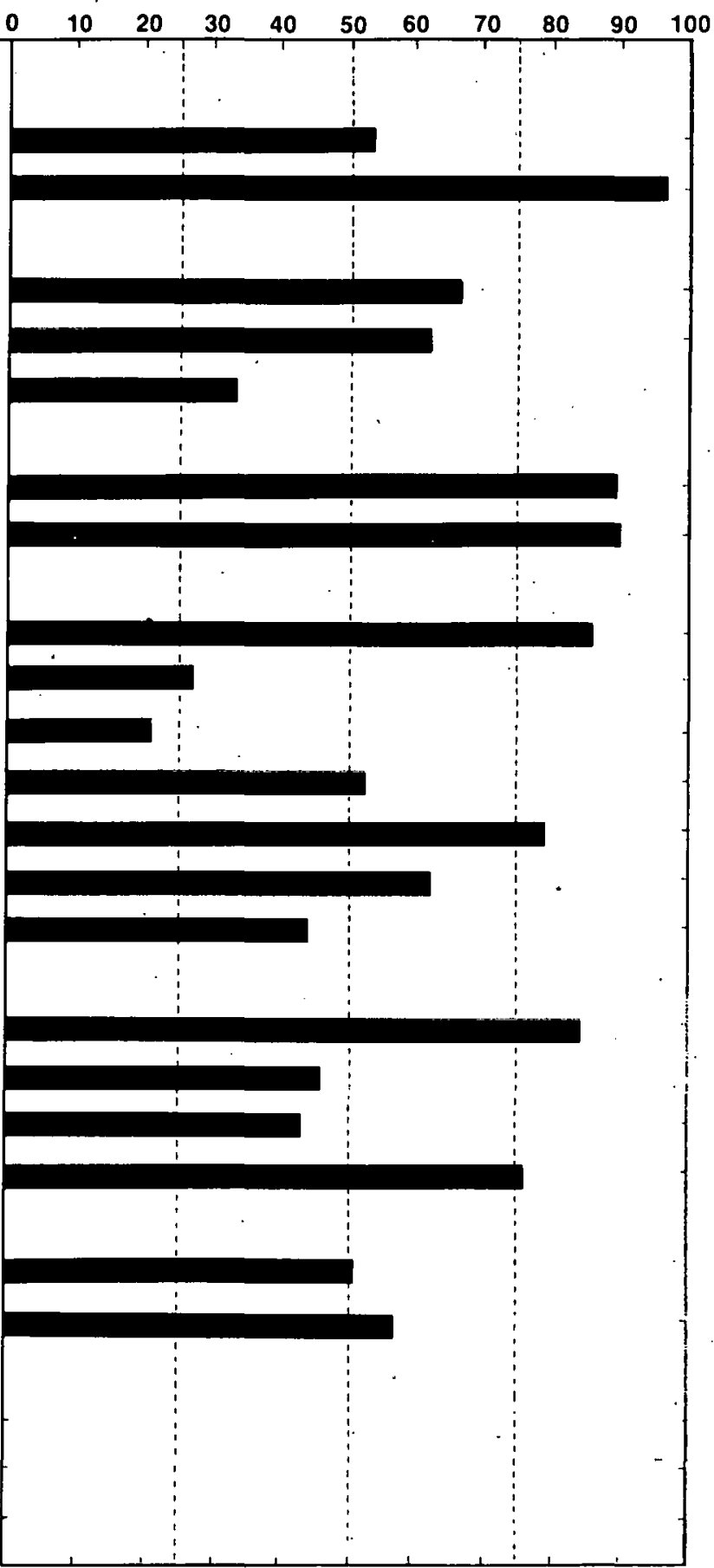

$\therefore$ Services and centers whose primary purpose is to disseminate Information

These data arc based upon a total of 63 rcspondents.

Figure 8-4. Use of Selected Information Sources: All Educators 
The information sources mentioned least of ten by Biomass Educators were:

- A commercial data base,

- Smithsonian Science Information Exchange (SSIE),

- Bio-Energy Council, and

- Solar Energy Industries Association (SEIA).

Three of these (other Educator groups were not asked about Bio-Energy Council) were also among the lowest-rated items for All Educators.

\subsubsection{Membership in Solar-Interested Organizations}

All of the 9 Biomass Educators interviewed were members of a professional, technical, or other organization with an interest in solar energy. These organizations (and the number of times mentioned) were:

- American Association for the Advancement of Science;

- American Association of Physics Teachers;

- American Council on Energy and Power;

- American Industrial Arts Association (2);

- American Society of Heating, Refrigerating and Air Conditioning Engineers;

- American Society of Mechanical Engineers (ASME), Solar Division (2);

- Bio-Energy Council;

- Environmental Action;

- Friends Of the Earth;

- International Solar Energy Society (ISES) (3);

- National Council on Energy;

- Northern California Solar Energy Society;

- Texas Solar Energy Society; and

- World Future Society.

The naming of a variety of types of organizations (professional, solar, and public interest) was typical of Educators. Six of the 9 Biomass Educators were members of solar-specific and/or public interest environmental organizations.

\subsubsection{Exposure to Publications on Solar Energy}

During the past 6 months, all 9 Biomass Educators had read publications which included information on biomass energy. The publications they could specify (and the number of times mentioned) included:

- Alternative Sources of Energy,

- ASME publications, 
- Bio-Energy Directory,

- U.S. Department of Energy (DOE) publications,

- Energy Primer (book; edited by R. Merrill, T. Gage),

- Forestry journals,

- International Solar Energy Society (ISES) publications,

- MITRE' reports,

- Mother Earth News,

- National Technical Information Service (NTIS) publications,

- New Era (book by C. Caryl),

- Northeast Regional Commission publications,

- Popular Science,

- Science,

- Solar Energy (2), and

- Solar Power and Fuels (book; edited by J. Bolton).

The list includes journals, popular periodicals, technical reports, books, and directories. Again, this reflects a variety typical of Educators in this study.

\subsubsection{Use of Special Acquisition Methods}

The respondents were asked whether they had obtained any information (not just biomass or solar energy) in the past year by computer terminal, by Computer Output Microform (COM), or by other microform (e.g., microfiche, microfilm sheets or rolls). Few of the Biomass Educators appeared accustomed to using computer equipment for information access. Only 1 had used a computer terminal in the past year, none had used COM. Five of 9 (56\%), however, had used other microforms. Their use of other microform was higher than that for All Educators (33\%), while the proportion using the other two advanced dissemination formats was lower than that of All Educators.

\subsection{SUMMARY AND COMMENTS}

Nine postsecondary educators teaching courses which covered biomass energy were interviewed. All of these Biomass Educators taught at a college or university, generally in a environmental science or technical education department. Their degree of informedness, level of involvement, and educational level were all slightly lower than those of other educators interviewed in this study.

Biomass Educators attached the greatest usefulness to information on:

- Climatological data,

- The state of the art in biomass energy systems,

- Biomass energy system research in progrcss, 
- Costs of installing and operating a biomass energy system compared to a conventional system, and

- A bibliography of general readings on biomass energy systems.

They found the following information items not to be very useful: "solar energy programs ... outside the U.S.," "marketing statistics and sales projections," "economic incentives," "calendars of conferences," and "lists of local lenders, insurers (etc.)."

Biomass Educators most often received solar information through "an installer, builder, designer, or manufacturer," "periodicals," "workshops," state energy or solar offices, USDA, and "private solar energy or environmental organizations." Many of them appeared to have used a great variety of sources rather than being limited to one or two. 


\section{SECTION 9.0}

\section{COUNTY AGENTS, COOPERATIVE EXTENSION SERVICE}

\subsection{DESCRIPTION OF RESPONDENTS}

\subsubsection{Description of Sample}

This section describes the results of a telephone study to determine the needs of county agricultural agents in the Cooperative Extension Service (CES) for information on biomass energy systems. Nine county agents were interviewed.

The sample frame for Biomass County Agents was selected from the County Agents Directory [8] which lists CES staff members by county. Any counties with less than 35\% of total land area in farms according to the County and City Data Book [9], were eliminated from consideration. The 2,160 remaining rural counties were reduced to 300 by selecting every seventh county. (Counties were listed in alphabetical order within states, which were also in alphabetical order.) Every fifth county was then selected as a candidate for the biomass information survey.* Senior Agricultural Agents (rather than Home Economics, 4-H, or Youth Agents) were identified for each county. (However, home economists were interviewed as referrals if they turned out to be the biomass specialist. See procedure below.) After all adjustments, the 9 interview candidates were randomly selected from a sample frame of 60 names.

Respondents. In making the telephone calls to contact the randomly selected interview candidates, it sometimes occurred that the person could not be reached. In this event another randomly selected name was substituted for the original name. When individuals were contacted, it was verified that they really had some experience with biomass energy systems, and that they would be needing information on biomass within the next year. If they were not both involved and needing information, they were asked if they could refer the interviewer to someone else in their organization who would be an appropriate respondent. If such a referral was made, a call was then made to this new candidate; if no intraorganizational referral was made, a new candidate was randomly selected from the sample framc. The results of this proness may be seen in Table 9-1.

Comparisons. For additional insight into the information needs and the information habits of these Biomass County Agents, results from this group are compared to the results from all of the CES county agricultural agents interviewed in this study (All County Agents) and from state level CES specialists in agriculture and information (All State Specialists). Other technologies represented by All County Agents included active solar heating and cooling, wind, passive solar heating and cooling, and agricultural process heat. In performing any statistical comparisons, the totals for Biomass County Agents have been subtracted from the totals for All County Agents. The data for Biomass County Agents, All County Agents, and All State Specialists can be found in Appendix F.

*The remaining counties were divided into similar groups, and studies were conducted on wind energy, active solar heating and cooling, passive solar heating and cooling, and agricultural process heat. The results of these studies are reported in other report volumes. 
Table 9-1. COMPLETION OF INTERVIEWS: BIOMASS COUNTY AGENTS

Event

Number of

Candidates

Interview completed with sample frame candidate

8

Interview completed with referral candidate

1

Refusal or candidate termination

0

Contact attempted: could not reach candidate within three

attempts or before interviews were completed

Subtotal

Contact attempted: invalid candidate (e.g., inappropriate

field of interest, no telephone)

'I'U'I'AL

Sample frame error rate (Percent) $^{a}$

Completion rate ${ }^{b}$ (Percent)

anvalid candidates divided by TOTAL

$b_{\text {Completed interviews divided by Subtotal }}$

\subsubsection{Current Status of Respondents}

Respondents represented counties in the following eight states:

- Indiana (2),

- Maryland,

- Montana,

- New Mexico,

- Ohio,

- Oregon,

- 'l'ennessee, and

- Texas.

Unfortunately, no Northeastern states appear in the list. . All County Agents accounted for 24 states, picking up somewhat more representution of the South. Similarly, All State Specialists (13 states) were not interviewed in New England nor the Far West. (Geographic distribution by state of respondents in each of the County Agents' and State Specialists' groups are shown in Appendix B, Table B-1.)

Role. In spite of the fact that all of the 9 Biomass County Agents expected to need biomass information in the next year, 4 of the 9 stated that they were currently doing very little in the area of biomass energy. However, 2 of these were accumulating information for future programs. Other activities which were mentioned included providing information (2 respondents), grain drying, working with dairymen on manure storage systems, and staying up to date on biomass technologies (especially in the area of wood products and agricultural residues). 
Involvement. Four of the 9 respondents said that they were "moderately involved" in biomass energy systems. The other 5 were "slightly involved." While none of the Biomass County Agents were "very involved," 33\% of All State Specialists were "very involved." Involvement levels of County Agents in other technologies were not significantly different from those of Biomass County Agents.

Informedness. Seven of the 9 Biomass County Agents stated that they were only "slightly informed" about biomass energy systems. The other 2 (22\%) were "moderately informed." Similar results were observed for All County Agents (only 22\% were at least "moderately informed"). However, All State Specialists were significantly (P 0.05$)$ more informed, with $83 \%$ at least "moderately informed."

Need for Information. All respondents indicated they would need information on biomass energy on the job during the next year. Only 2 (22\%) of the 9 Biomass County Agents also expected to need information on biomass energy outside the job. This was a lower level of expected off-the-job information need than was found for All County Agents, where 21 of the $45(47 \%)$ responded similarly or for All State Specialists (7 of the 18 or $39 \%)$.

\subsubsection{Background of Respondents}

Five of the Biomass County Agents held master's degrees, 1 held a PhD, and the remainder held bachelor's degrees. Five had received their most recent degree in animal science, 1 in dairy science, 1 in adult education, and 2 in agriculture. Two of the 9 had received their most recent degrees 25-30 years ago, 5 from 5-15 years ago, and 2 within the past 4 years. This was fairly typical for County Agents, as 31 of the 45 (69\%) All County Agents received degrees within the past 20 years.

Seven Biomass County Agents had been in their current profession for over 10 years, 2 for 3-5 years. Although their current profession might be assumed to be "county extension/agricultural agent," their definition of their present professions included educator and animal scientist, as well as Extension Agent.

\subsection{NPORMATION NEEDS OF RESPONDENTS}

\subsubsection{Technical Areas}

Biomass County Agents were asked to choose those areas in which they were "particularly interested in obtaining information" from a list of selected technical areas of biomass energy technology. Four expressed interest in all six areas about which they were asked. Interest levels were highest ( 8 of the 9 respondents were interested) for "liquid fuels from biomass materials" and "gases from biomass materials." Six of the 9 were interested in "residential burning of wood," 5 were interested in "commercial or industrial burning of biomass," and 4 in "growth or collection of biomass materials" and in "burnable pellets, etc., from biomass."

\subsubsection{Types of Information}

Biomass County Agents were asked to name the information about biomass energy technologies that was important for them to obtain. Eight of the 9 volunteered one or 
more items of information which they considered important. Not all of their responses appeared to be related to biomass and 1 respondent asked for a definition of biomass. Topics mentioned in response to the question included: economics; feasibility of new systems; construction steps; solar housing; individual farming operations; insulation; drying ovens; structural design for agricultural study; making energy products from wastes; use of municipal wastes; methane fuels; protein by-products from biomass fuel production; demand for carbon dioxide; processes for separating carbon dioxide and other biogases; and safe procedures for collecting, handling, and compressing methane gas.

Three Biomass County Agents volunteered that there was information they needed but were unable to get. This information included: design /and cost figures, specifics on solar housing, and practical applications of biomass for energy.

Choice Between Specific Needs. A list of 11 types of biomass energy information products and 11 types of biomass energy information categories was read to each respondent. Each respondent described the usefulness of each particular item by assigning it a value of "essential," "very useful," "somewhat useful," or "not at all useful." The results are given in Fig. 9-1. For comparison, results for All County Agents are in Fig. 9-2, those for All State Specialists in Fig. 9-3.

The six top-rated information categories/products selected by the Biomass County Agents were:

- Costs of installing and operating a biomass energy system compared to a conventional system;

- Lists of sources for information;

- Costs and performance of systems;

- Climatological data;

- Tax credits, grants, or other economic incentives; and

- A nontechnical description of how a particular system works.

These items were also the six top-rated information categories/products for All County Agents.

Biomass County Agents assigned the lowest relative ratings to:

- Computer models for sizing and predicting performance or costs;

- Local building codes or other regulations;

- Calendars of conferences and programs;

- Manual methods for sizing and predicting performance or costs;

- Institutional, social, environmental, and legal aspects; and

- Lists of technical experts.

Statistical tests indicated that differences between the six highest-rated and six lowestrated items were significant $(P<0.05)$ for this group.

It should be noted that these lower-rated items were not necessarily of no worth to the Biomass County Agents. For example, 1 of the 9 (11\%) thought "local building codes" 
Question \#8. I will read a list of polential information or information products on solar systems. For each, please tell me how useful that information would be to you. Would the following be: essential, very useful, somewhat useful, or not at all useful?

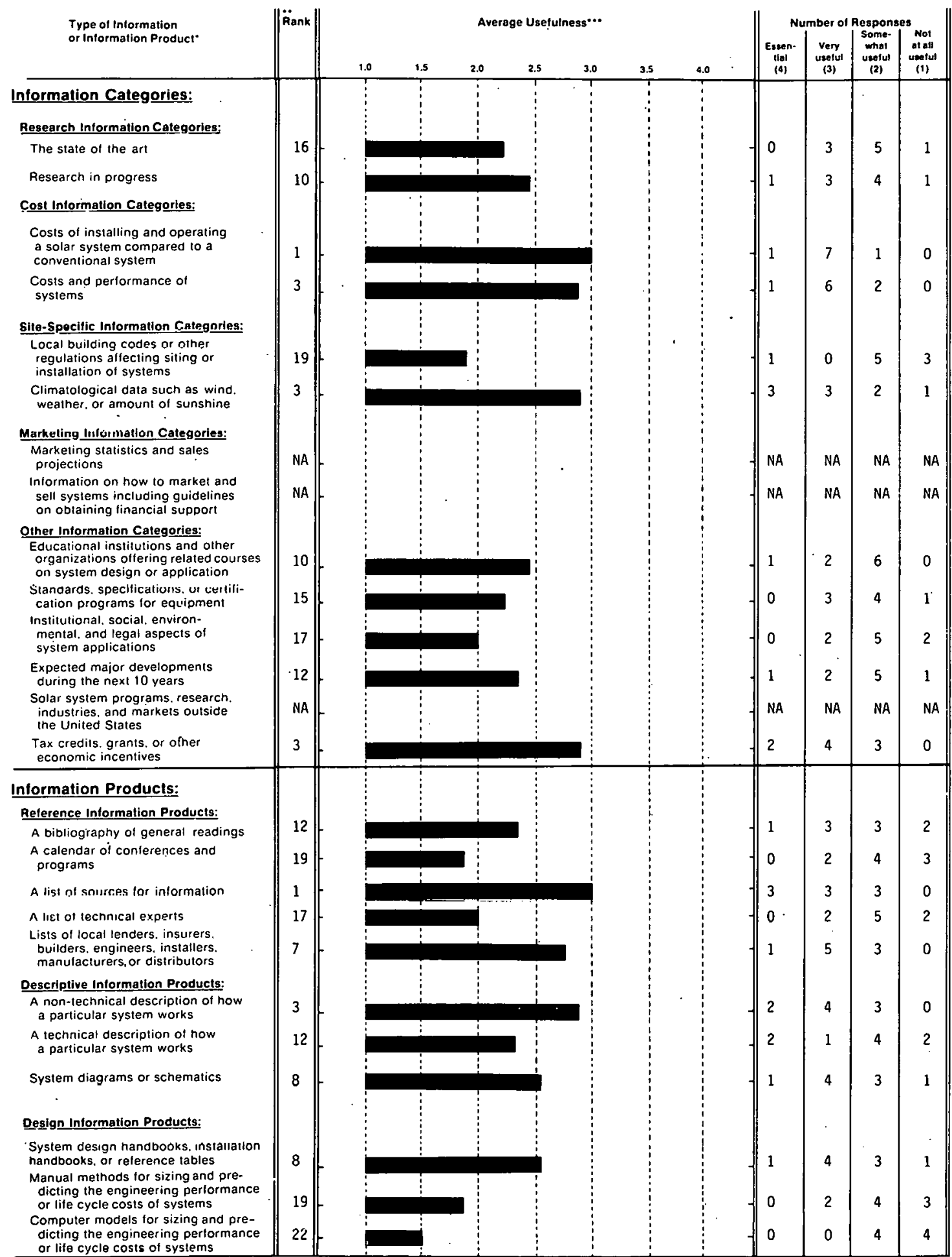

Eacn sample trame of users was questioned on intormation and information products in the context of their specilic technology. For example. bromass sample trames were "Aank-Each inlormation product was assigned on biomass". "a calencar of upcoming tiomass cont with the highest average usefulness was assigned the rank of " 1 ": the product with the lowdst averagt usefulness would be canked "25" where ull items were asked. II Iwo or more information produsts wore lied lor and. they wero both assigned a "2", The next

. "'igness ranking was then assigned a "4:"

Figure 9-1. Usefulness of Selected Information Items: Biomass Cooperative Extension Service County Agents 
Question \#8. I will read a list of potential information or information products on solar systems. For each, please tell me how useful that information would be to you. Would the following be: essential, very useful, somewhat useful, or not at all useful?

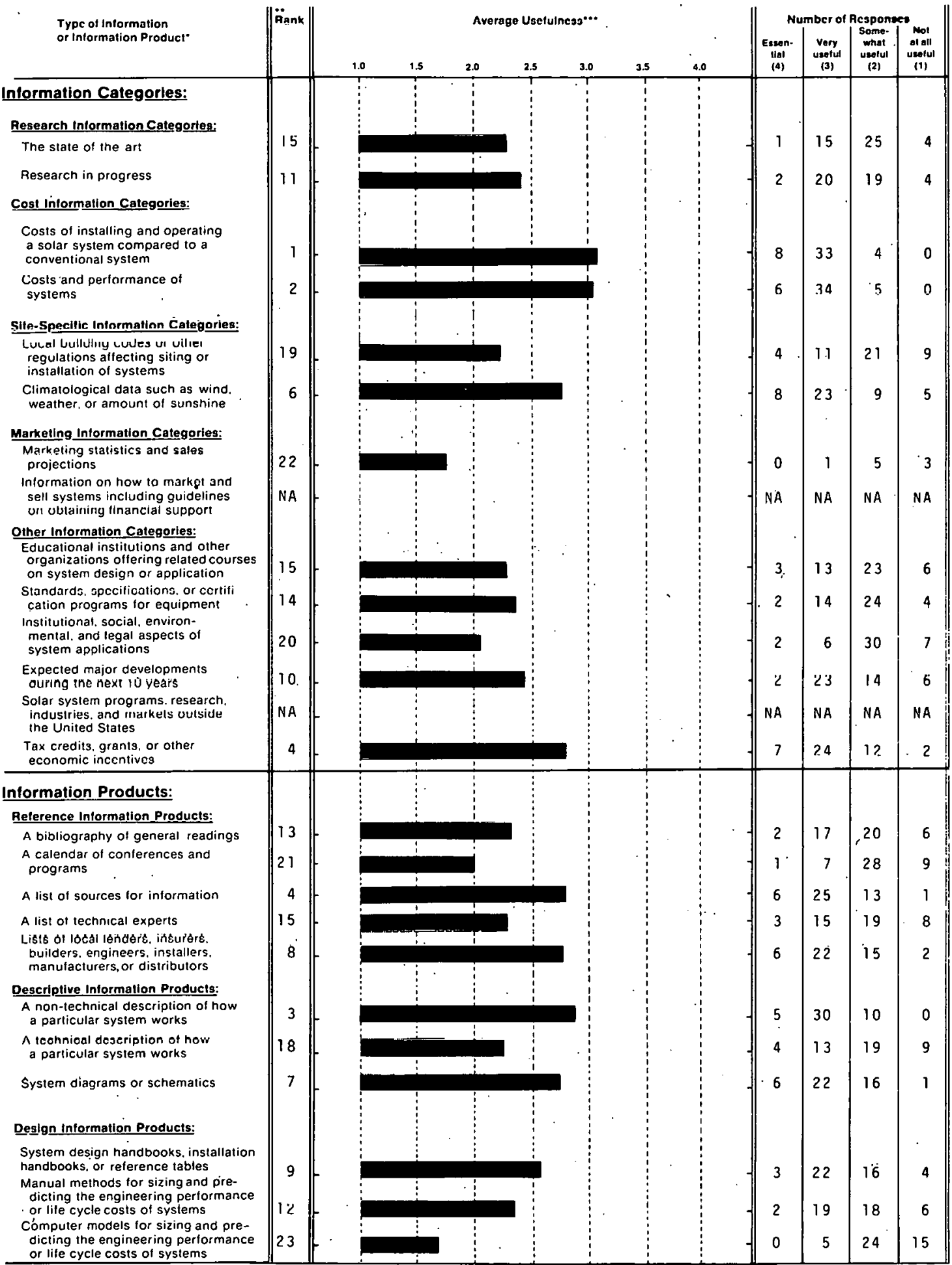

Each sample lrame of users was questioned on inlormation and information procucts in the context of their speciltc technology. For example. biomass sample trames were

Rank - Each inlormation product was assigned a rank based on average uselutness. Thus. Ihe product with the highest average usefulness was assigned ine rank of " 1 ", the product with the lowest average uselulness would be ranked "25" where all terns were asked. It two or more intormation products were tied for 2 nd, they were both assigned a "2". The ne Ingnes: ranking was inen assigned a "4:

Figure 9-2. Usefulness of Selected Information Items: All Cooperative Extension Service County Agents 
Question \#8. I will read a list of potential information or information products on solar systems. For each, please tell me how useful that information would be to you. Would the following be: essential, very useful, somewhat useful, or not at all useful?

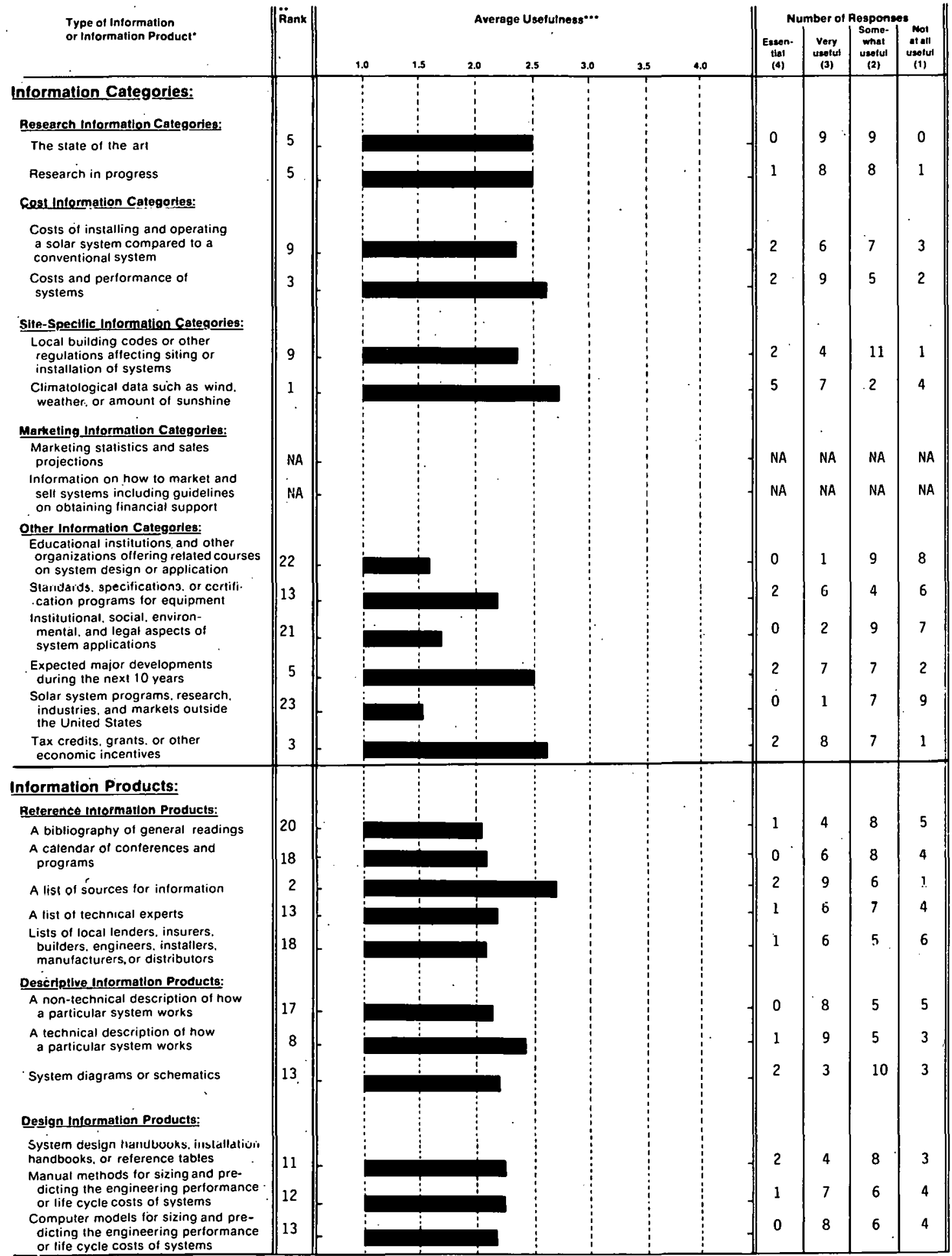

Each sample trame of users was questioned on intormation and inlormation products in the context ol their specific technology. For example. biomass sample tromes were asked about "a bibtiography of general readings on biomass"." "a calendar of upcoming tiomass conferences and programs ". etc.

Rank - Each inlormation product was assigned a rank based on average usefulness. Thus, Ihe product wilh the highest average usefunthess was assigned the rank of "I": Ihe product

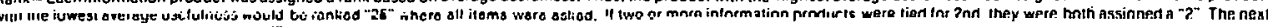

Figure 9-3. Usefulness of Selected Information Items: All Cooperative Extension Service State Specialists 
were "essential." Thus, these information categories/products could be useful to some of the Biomass County Agents, but were of a lower relative priority to the entire group.

Statistical tests were also used to determine whether the Biomass County Agents rated any of these information items significantly higher (or lower) than they were rated by All County Agents or All State Specialists. Some groups, however, tended to give higher scores in general than did other groups. To compensate for this effect, these statistical tests compared the "relative rating" given by one group to the "relative rating" given by the other groups. The procedure for calculating the relative rating is described in Appendix E. The average overall rating Biomass County Agents gave to all items was 2.41; for All County Agents it was 2.47; and for All State Specialists, 2.27.

In comparing the results for Biomass County Agents to the results for All County Agents, ratings were very similar. Statistical tests indicated that All County Agents gave significantly $(\mathrm{P}<0.05)$ higher ratings to "manual methods."

Biomass County Agents differed somewhat more, however, from All State Specialists. Biomass County Agents gave significantly $(\mathrm{P}<0.05)$ higher ratings to "educational institutions" and "a nontechnical description." All five County Agents groups rated "a nontechnical description" higher than did the State Specialists. It is speculated that the need by County Agents for nontechnical information was for the purpose of distribution to the public. Biomass County Agents gave significantly $(P<0.05)$ lower ratings than All State Specialists to "computer models," "the state of the art," and "local building codes."

\subsection{ACQUISITON OF INFORMATION BY RESPONDENTS}

\subsubsection{Use of Selected Information Sources}

Biomass County Agents were asked which of 22 different potential sources of snlar information they had used in the past few years. For this question the respnndents were not asked if they had obtained information on biomass technologies, but instead were asked if they had obtained any solar information from each specific source. Thus, the question sought to determine which information sources were the most familiar to the respondents. The results are shown in Fig.9-4. For comparison, results for All County Agents and All State Specialists are in Figs. 9-5 and 9-f.

The information sources mentioned most of ten by Biomass County Agents were:

- IIniter States Department of Agrioulture (USD $\Lambda$ ),

- Pulividiculs, newspupcrs, or magazines;

- The Government Printing Office (GPO);

- Directly from the U.S. Department of Energy (DOE); and

- State energy or solar offices.

The information sources mentioned least of ten by Biomass County Agents (no more than 1 of the 9 had used them) were:

- Solar Energy Industries Association (SEIA),

- Smithsonian Science Information Exchange (SSIE), 
Question \#11. In the past few years, have you obtained any type of solar information from any of the following sources?

Information. Sources
Percentage Responding Yes ${ }^{* .}$

Public Media:

Radio or TV

Periodicals. newspapers or magazines

Private Solar-Involved Organizations:

Private solar energy or environmental órganizations

The lucal chaplé o viatiunal headquarters of International Solar Energy Society (ISES), including their publications

The local chapter or national headquarlers ul Solai Energy

Industrles Association (SEIA), includinig their publications

Contacts with Protessionals:

An installer, builder, designer ur manulaclurer of sölar systems

Workshops, conferences or training sessions

\section{Information Services*:}

Your organizational library or a local library

A commercial data base: for example. Lockheed, SDC, BRS

Smithsonian Science Information Exchange (SSIE)

A Federal library or information center; for example, the National Agricultural Library or the Environmental Data System

The Government Printing Office (GPO)

National Technical Information Service (NTIS)

Technical Iniormation Center at Oak Ridge (TIC)

\section{Government Solar-Involved Organizations}

Directly from the U.S. Department of Energy

National Solar Heatıng \& Cooling Information Centeı

Regiona! Solar Energy Centers

State Energy or Solar Uitices

Other:

Some other state or local government office or publication

A public utility company

Sources for this specilic sample frame*::

USDA, including Extension and Forestry

Dio-Energy Couneil

Wood Energy Institute

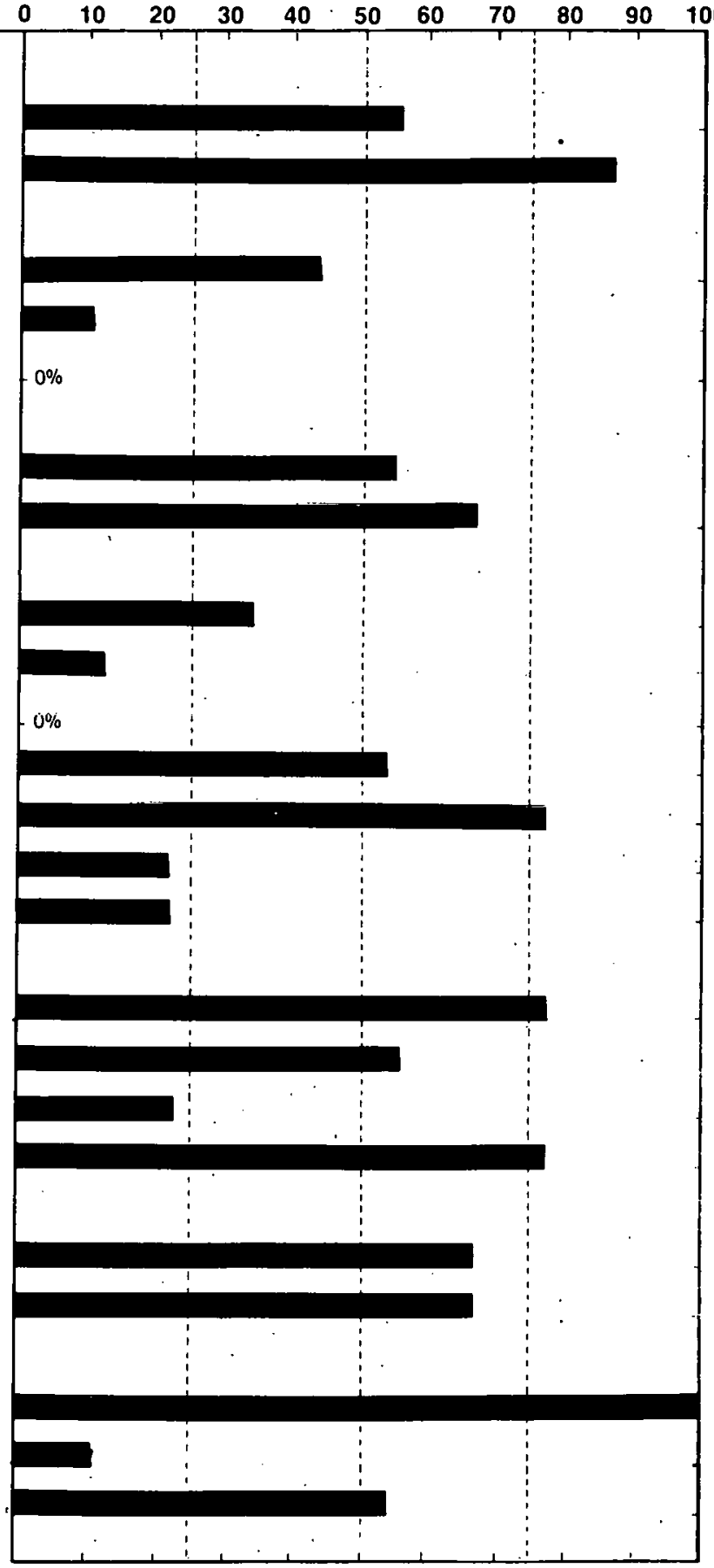

- Services and centers whose primary purpose is to disseminale information.

- Some sample frames were questioned about additional information sources which are applicable to their technology. For example. the manufacturers of biomass conversion equipment were also asked if they have obtained any type of solar information trom: "the local or mational officc of the U.S. Dopartment of Agriculture, including Extensinn and Forestry"

... These data are based upon a total of 9 respondents.

Figure 9-4. Use of Selected Information Sources: Biomass Cooperative Extension Service County Agents 
Question \#1.1. In the past few years, have you obtained any type of solar information from any of the following sources?

Information Sources

Public Media:
Radio or TV
Periodicals. newspapers or magazines

Private Solar-Involved Organizations:

Private solar energy or environmental organizations

The local chapter or national headquarters of Internationa Solar Energy Society (ISES). including their publications

The local chapter or national headquarters of Solar Energy Industries Association (SEIA), including their publications

Contacts with Professionals:

An installer, builder. desıgner or manulacturer of solar systems

Workshops. conferences or training sessions

Information Services*:

Your organizational library or a locat library

A commercial data base: for example. Lockheed, SDC. BRS

Smithsonian Scicnce Information Exchange (SSIE)

A Federal library or information center: for example. the National Agricultural Library or the Environmental Data System

The Government Printing Office (GPO)

National Technical Information Service (NTIS)

Technical Information Center at Oak Ridge (TIC)

Government Solar-Involved Organizations

Directly from the U.S. Department of Energy

National Solar Heating \& Cooling Information Cente

Regional Solar Energy Centers

State Energy or Solar Offices

Other:

Some other state or local government office or publication

A nuhlis uifility rommany

Solurses for this epecific samplo framo**

USDA, including the Cooperative Extension Service
Percentage Responding Yes ${ }^{\cdots}$

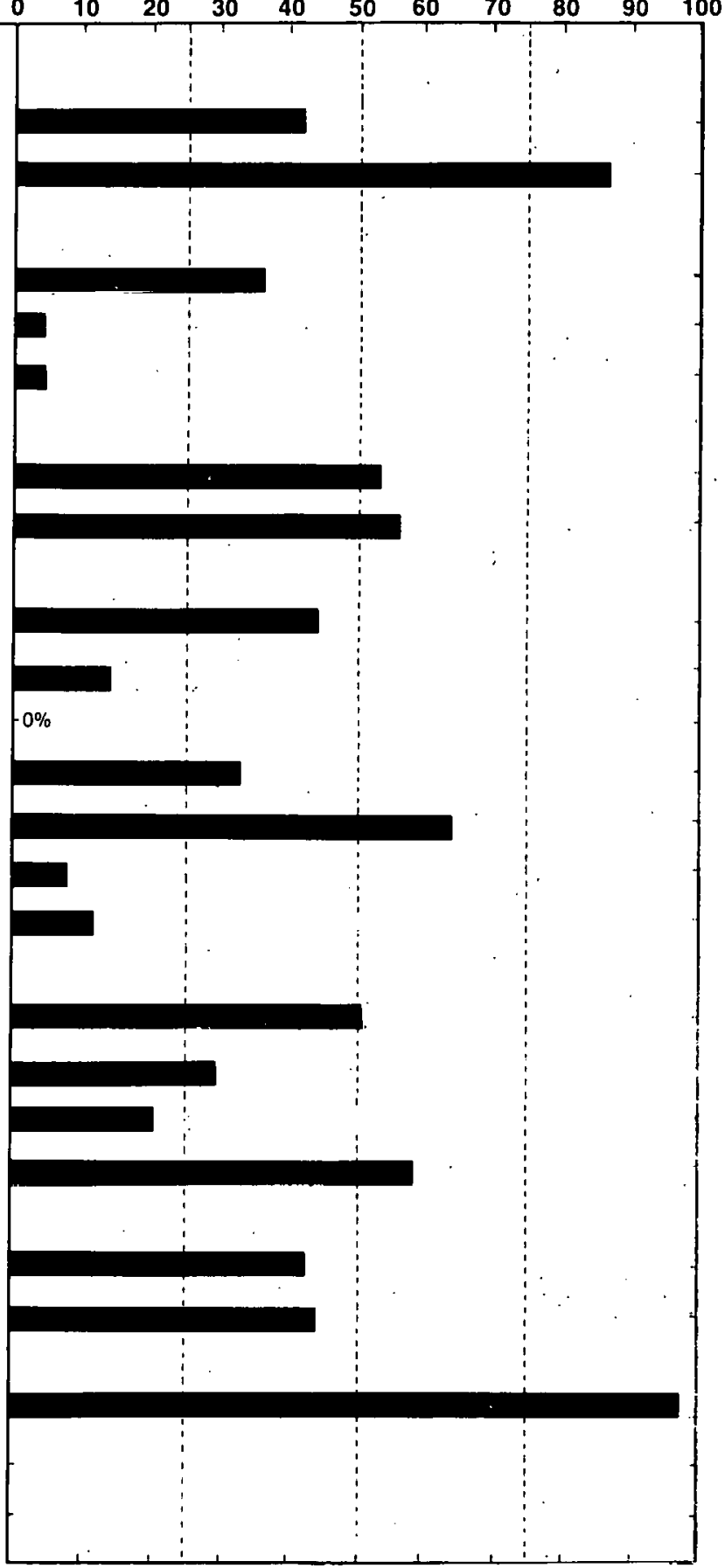

- Services and centers whose primary purpose is to disseminate information

- Some sample frames were questioned about additional information sources which are applicable to their technology. For example. the manufacturers of biomass conversion equipment were also asked if they have obtained any type of solar information from: "the local or national office of the U.S. Department of Agriculture. including Extension and Forestry:"

... These data are based upon a total of 45 respondents.

Figure 9-5. Use of Selected Information Sources: All Cooperative Extension Service County Agents 
Question \#11. In the past few years, have you obtained any type of solar information from any of the following sources?

Information Sources

Percentage Responding Yes $\cdots$

Public Media:

Radio or TV

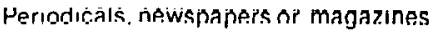

Private Solar-Involved Organizations:

Private solar energy or environmental organizations

The local chapter or national headquarters of International Solar Energy Society (ISES), including their publications

- The local chapter or national headquarters of Solar Energy Industries Association (SE|A), including their publications

Contacts with Protessionals:

An installer, builder, designer or manufacturer of solar systems

Workshops. conferences or training sessions

Information Services":

Your organizational library or a local library

A commercial data base: Ior example, Lockheed, SDC. BRS

Smithsonian Science Information Exchange (SSIE)

A Federal library or information center; for example. the National Agricultural Library or the Environmental Data System

Tno Covnrnmont Printing Office (GPQ)

National Technical Intormation Service (NTIS)

Technical Information Center at Oak Ridge (TIC)

Government Solar-Involved Organizations

Directly from the U.S. Department of Energy

National Solar Heating \& Cooling Information Center

Regional Solar Energy Centers

State Energy or Solar Offices

Other:

Some other state or local government office or publication

A public utility rompany

Sources for this specific sample frame**:

USDA, including the Cooperative Extension Service

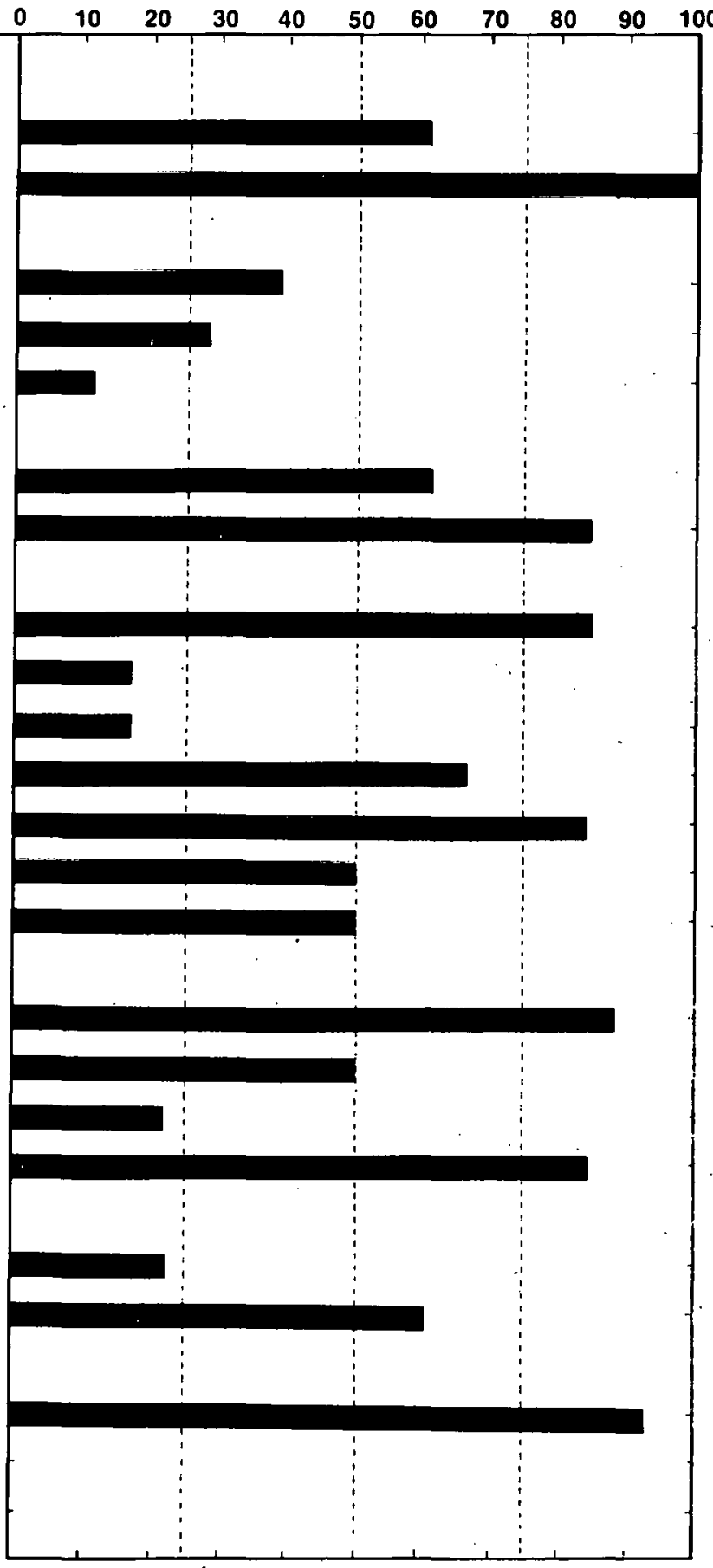

- Services and cenlers whose primary purpose is to disseminate information.

$\because$ Some sample frames were guestinned about additional information sources which are applicable to their technology. For example. the manufacturers of biomass conversion equipment were also asked it they have obtained any type of solar information irom: "the local or national office of the U.S. Department of Agriculture, including Extension and Forestry."

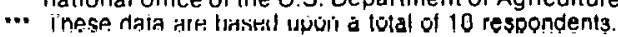

Figure 9-6. Use of Selected Information Sources: All Cooperative Extension Service State Specialists 
- International Solar Energy Society (ISES),

- A commercial data base, and

- Bio-Energy Council.

Although Biomass County Agents rated "periodicals, newspapers, or magazines" among their top three solar information sources, they were able to name only four publications (see Section 10.3.3) in which they had seen solar information in the past 6 months. None of these publications were specifically solar or energy oriented. Additionally, none were USDA publications nor GPO documents.

In reviewing Figs. 9-4 through 9-6, all three groups made high use of USDA and "periodicals." Biomass County Agents were significantly $(P<0.05)$ less likely than All State Specialists to have used "a . . library" as a solar information source.

\section{3:2 Membership in Solar-Interested Organizations}

Only 2 of the 9 Biomass County Agents interviewed were members of a professional, technical, or other organization with an interest in solar energy. The organizations (each mentioned by only 1 respondent) included:

- American Home Economics Association,

- Business and Professional Women,

- Governor's Council on House Energy (Montana),

- Montana Home Economies Association, and

- National Association of County Agricultural Agents.

\subsubsection{Exposure to Publications on Solar Energy}

During the past 6 months, 7 of the 9 Biomass County Agents had read publications that included information on biomass energy applications. The publications they could specify (each mentioned by only 1 respondent) included:

- Farm,

- Farm Journal,

- Farm publications,

- Hoard's Dairyman,

- Ohio State bulletins (on converting livestock waste into fuel),

- Prospectus on biomass processing unit or plant, and

- Purdue University publioations.

\subsubsection{Use of Special Acquisition Methods}

The respondents were asked whether they had obtained any information (not just biomass or solar energy) in the past year by computer terminal, by Computer Output Microform 
(COM), or by other microform (e.g., microfiche, microfilm sheets or rolls). Few of the Biomass County Agents appeared accustomed to using these special acquisition methods, a trait common to All County Agents. In the past year, only 1 of the 9 had used computer terminals, Computer Output Microform (COM), or other microform. Somewhat larger proportions of All State Specialists had used each of the three forms, but differences were not significant.

\subsection{SUMMARY AND COMMENTS}

Nine CES County Agents were interviewed. Eight were Agricultural Agents and one was a Home Economist. All had some experience in collecting and disseminating biomass information and expected to be doing so in the next year, al though they were not necessarily involved presently. Their level of involvement, degree of informedness, and educational levels were typical of County Agents interviewed in this study.

Biomass County Agents found these information products/services to be the most useful:

- Costs of installing and operating a biomass energy system compared to a conventional system;

- Lists of sources for information on biomass energy systems;

- Costs and performance of biomass energy systems;

- Climatological datu;

- Tax credits, grants, or other economic incentives for biomass energy applications; and

- A nontechnical description of how a particular biomass energy system works.

They found the least utility in "manual methods," "computer models," "local building codes," "institutional ... and legal aspects," and "lists of technical experts." County Agents generally found the last two items not to be very useful. Liquid fuels and gases from biomass materials were highest on their list of areas of interest in biomass, followed by residential wood burning.

The USDA is clearly the most important source for information on biomass, with "periodicals" also very popular. Other popular sources were GPO, DOE, and state energy. or solar offices. Biomass County Agents generally did not belong to private organizations which provided solar information. They also rarely read solar-specific publications, although farm journals and university publications did provide them with some solar information. 


\section{SEPR}


SECTION 10.0

BIOMASS SYSTEM MANAGERS

\subsection{DESCRIPTION OF RESPONDENTS}

\subsubsection{Description of Sample}

This section describes the results of a telephone study to determine the needs of managers of biomass energy conversion systems (excluding domestic wood stoves) for information on biomass energy systems. A total of 7 managers of biomass energy systems were interviewed (initially 9 were sampled, but 2 were disqualified for having no current involvement with biomass end products). The purpose of sampling this group was to determine the sources of information used in acquiring the original system and to determine, in retrospect, what types of information would have been most useful. By learning the information needs and the sources used, one can estimate the information needs and information habits of potential users of biomass systems.

The sample frame for Biomass System Managers was constructed from two MITRE Biomass Reference Directories: "Solar Energy Technical Information Dissemination Program. Reference Directory: Fuels from Biomass" and the June 1979 update to the aforementioned [10]; and from the Electric Utility Solar Energy Activities, 1978 Survey [11] by the Electric Power Research Institute (EPRI). In the April, 1979 MITRE source, names were chosen from the End-User section if they were: (1) industrial plants using wood or waste for steam/heat production, (2) utilities using forest residues for steam/electricity production, and (3) wood, wood products, timber industry companies using wood for power. In the June, 1979 MITRE source, additional names were chosen from the End-User section if they were: (1) utility companies, (2) local government users (i.e., municipalities), and (3) small private commercial users that were not individuals or universities. Three additional Biomass utility users were obtained from the EPRI source. After any duplicates between lists were eliminated the 9 interview candidates were randomly selected from a sample frame of 32 names.

Respondents. In making the telephone calls to contact the randomly selected interview candidates, it sometimes occurred that the person could not be reached. In this event, another randomly selected name was substituted for the original name. When individuals were contacted, it was verified that they really were involved with the operation of a biomass energy conversion system. If they were not the representative of a biomass end user, they were asked if they could refer the interviewer to someone else involved with the operation of a biomass energy conversion system who would be an appropriate respondent. If such a referral was made, a call was then made to this new candidate; if no referral was made, a new candidate was randomly selected from the sample frame. The results of this process may be seen in Table 10-1.

Comparisons. For additional insight into the information needs and the information habits of these Biomass System Managers, results from this group are compared to the results from Active Solar Heating and Cooling (SHAC) Building Owners/Managers (including owners or managers of nonfederal solar buildings). The data for Biomass System Managers and for S.HAC Building Owners/Managers can be found in Appendix F. 
Table 10-1. COMPLETION OF INTERVIEWS: BIOMASS SYSTEM MANAGERS

Event

Number of

Candidates

Interview completed with sample frame candidate

Interview completed with referral candidate

Refusal or candidate termination

Contact attempted: could not reach candidate within three

attempts, or before interviews were completed

Subtotal

Contact attempted: invalid candidate (e.g., inappropriate

field of interest, no telephone)

TOTAL

Sample frame error rate (Percent) $^{a}$

Completion rate ${ }^{b}$ (Percent)

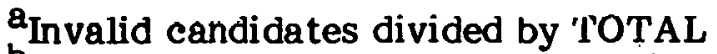

$\mathrm{b}_{\text {Completed interviews divided by Subtotal }}$

\subsubsection{Current Status of Respondents}

One of the 7 Biomass System Managers was working for a sanitary district, 1 for a state Audubon Society, 1 for a utility, and the remaining 4 for industries. Two of the 7 biomass energy systems converted municipal solid waste to energy. Another 2 respondents were involved in heat recovery systems including an incinerator tied to a boiler (heat was diverted from the stack to heat the boiler) and a heating system recovering steam from the city's incinerator. The type of systems mentioned hy the remaining 3 respondents included: a wood furnace backup for a solar system heating a 6,000 $\mathrm{ft}^{2}$ office building, a woodwaste-burning boiler, and a spreader-stoker boiler which burned wood pellets.

Four of the 7 respondents were managers when the biomass eonversion system was installed; in the 3 other cases, the system was installed under the direction of a previous manager. Four of the Biomass System Managers had been managers of the system for 1-3 years and the other 3 had over 3 years of management experience with their system. The length of time they were responsible for their system was similar to that of the SHAC Building Owners/Managers (in which 1 had less than 1 year experience, 4 had 1-3 years, and 3 had more than 3 years experience).

\subsubsection{Background of Respondents}

Four of 7 Biomass System Managers held bachelor's degrees, one had no degree, one held an associate degree, and one a master's degree. One received his/her most recent degree 30 years ago, 1 from 20-25 years ago, 2 from 10-15 years ago, and 2 from 5-10 years ago. Five received engineering degrees and one had a degree in landscape architecture.

In their current professions, 4 of the Biomass System Managers were still in engineering and the other 3 were managers/administrators. 


\subsection{INPORMATION NEEDS OF RESPONDENTS}

Even though the Biomass System Managers already had an existing biomass energy conversion system, 4 of the 7 (57\%) Biomass System Managers indicated they would need additional information on biomass on the job, and $2(29 \%)$ outside the job during the next year. (Two of the 9 did not expect to need biomass information in the next year.) Comparatively, this was similar to the interest expressed by SHAC Building Owners/ Managers, with 6 of the 9 (67\%) needing information on the job and 2 (22\%) outside the job.

\subsubsection{Types of Information}

Biomass System Managers were asked to name the information about biomass that would be important for them to obtain if they were starting over again and first considering the installation. of a biomass conversion system. Six of the 7 Biomass System Managers volunteered one or more items of information which they considered important. Two felt information on the availability of biomass materials and supplies was important. Other topics receiving single mentions included: the reliability of biomass supplies and fuel costs, information on the economics of biomass systems, the cost justification of biomass compared to oil and gas, technical information on wood furnaces, methods to determine the amount of burnable scrap required to warrant installing a system, marketing data on selling energy produced from biomass, information on the ability to retrofit existing equipment for burning biomass, and information on heat storage.

Three of the 7 Biomass System Managers volunteered they needed but were unable to get information on wood-burning furnaces, air-injected high efficiency furnaces, and the burning characteristics of densified biomass.

Choice Between Specific Needs. A list of 11 types of biomass energy information products and 12 types of biomass energy information categories was read to each respondent. Each respondent described the usefulness of each particular item by assigning it a value of "essential," "very useful," "somewhat useful," or "not at all useful." The values assigned to each information product/category may indicate the values that would be assigned by individuals in industrial plants, utilities, or the wood/timber industries interested in hiomass energy. The results are given in Fig. 10-1. For the purpose of comparison, the results for SHAC Building Owners/Managers are included in Fig. 10-2.

Biomass System Managers selected the cost information category as most important. The four top-rated information categories/products were:

- Costs of installing and operating a biomass energy system compared to a conventional system;

- Tax credits, grants, or other economic incentives;

- Costs and performance of systems; and

- A technical description of how a particular system works.

Biomass System Managers assigned the lowest ratings to:

- Climatological data,

- Computer models for sizing and predicting performance or costs, and

- Calendars of conferences and programs. 
Question \#8. I will read a list of potential information or information products on solar systems. For each, please tell me how useful that information would be to you. Would the following be: essential, very useful somewhat useful, or not at all useful?

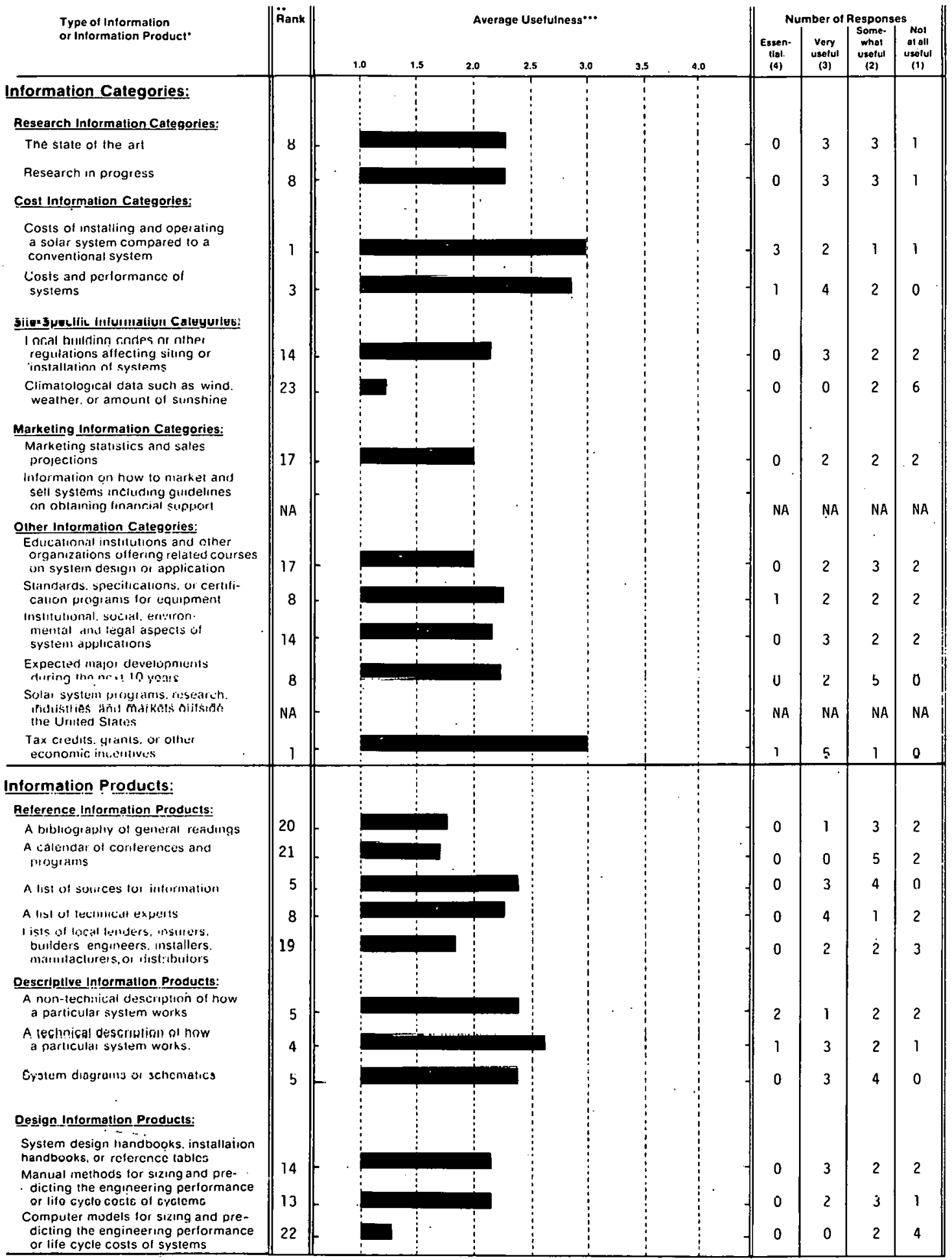

Each sample trame of users was questinned on unlormation and intormation products in the coniext ol their specific technology. For example. biomass sample trames were
ashed about "a bibliography of genetal teadings on biomass"." "a calendar ol uocoming biomass conferences and orograms " etc. ashed about "a bibllography of general readings on biomass"." "a catendar ol upcoming bromass conferences and programs ", elc.

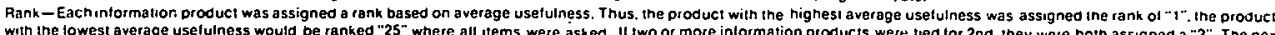
with the low

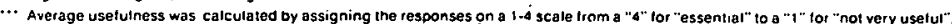

Figure 10-1. Usefulness of Selected Information Items: Biomass System Managers 
Question \#8. I will read a list of potential information or informalion products on solar systems. For each, please tell me how useful that information would be to you. Would the following be: essential, very useful, somewhat useful, or not at all useful?

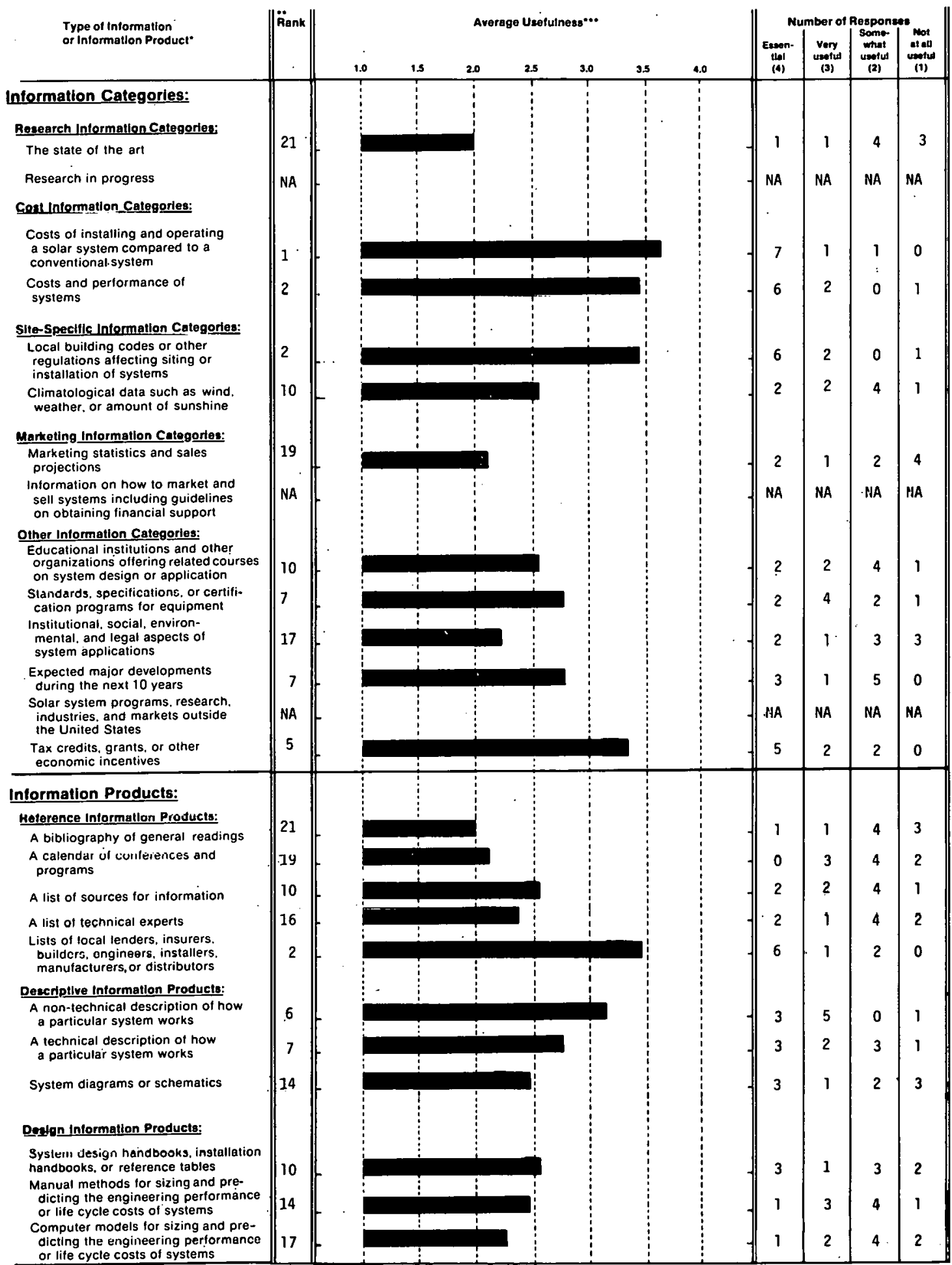

Each sample frame of users was questioned an intormation and infurmetion prod 129 he centext of their spocitie technology. For oxamplo. biomass ramplo irames were asked about "a bibliography of general read ings on biomass". "A calendar of upcoming biomass conterences and programs", etc.

- Rank-Eachintormation product was assigned a rank based on average usetulness. Thus. the product with the highest average usefulness was assigned the rank of "1": the producl

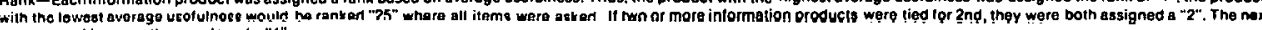

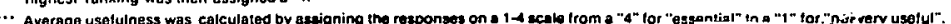

Figure 10-2. Usefulness of Selectod Information Hame: Actwe Solar Heating and Cooling Bullding Owmord Menesers 
Statistical tests indicated all four of the top categories/products were rated significantly $(P<0.05)$ higher than were the three lowest-rated items. It should be noted that these lower-rated items were not necessarily of no worth to the Biomass System Managers. For example, 2 of the 7 (29\%) thought "marketing statistics and sales projections" was "very useful." Thus, these information categories/products could be useful to some Biomass System Managers, but were of a lower relative priority to the entire group.

Statistical tests were also used to determine whether the Biomass System Managers rated any of these information items significantly higher (or lower) than they were rated by the SHAC Building Owners/Managers. Some groups, however, tended to give higher scores in general than did other groups. To compensate for this effect, these statistical tests compared the "relative rating" given by one group to the "relative rating" given by the other groups. The procedure for calculating the relative rating is described in Appendix E. The average overall rating was much lower for Biomass System Managers (2.20) than it was for SHAC Building Owners/Managers (2.70).

A comparison of Biomass System Managers to SHAC Building Owners/Managers identified the Biomass System Managers as significantly $(P<0.05)$ less interested in "lists of local lenders, insurers (etc.)" and "local building codes." The data also indicated the Biomass System Managers were more interested in "the state of the art," "a list of technical experts," and "system diagrams or schematics," but were less interested in "climatological data."

\subsection{ACQUISTION OF INPORMATION BY RESPONDENTS}

\subsubsection{Initial Information Sources}

Although the Biomass System Managers had already gone through the data gathering process, they were asked in retrospect what would be the first thing they would do to obtain information about biomass energy if they were starting over. The types of information sources mentioned varied widely, with single mentions made for the following sources: data bases (government and commercial), computer terminals, magazines (specifically Plant Engineering and Energy Management), a public service commission, a biomass directory, the Environmental Protection Agency (EPA), an engineering firm, a specific private company (the Kelley Company), an existing installation (called Woodex), and a personal contact at a university.

\subsubsection{Use of Selected Information Sources}

Biomass System Managers were asked which of 23 different potential sources of solar information they had used in the past few years. For this question the respondents were not asked if they had obtained information on biomass energy, but instead were asked if they had obtained any solar information from each specific source. Thus, the question sought to determine which information sources were the most familiar to the rcspondents. The results are shown in Fig. 10-3. For the purpose of comparison, the results for SHAC Building Owners/Managers (Fig. 10-4) are also included. 
Question \#11. In the past few years, have you obtained any type of solar information from any of the following sources?

\section{Information Sources}

Public Media:
Radio or TV
Periodicals, newspapers or magazines
Privale Solar-Involved Organizations:
Private solar energy or environmental organizations
The local chaf ter or national headquarters of International
Solar Energy Society (ISES). including their publications
The local chapter or national headquarters of Solar Energy
Industries Assnriation (SEIA). including their publications
Contacts with Professionals:

An installer, builder, designer or manufacturer of solar systems Workshops. conterences or training sessions Information Services*:

Your organizational library or a local library

A commercial data base; for example. Lockheed, SDC. BRS

Smithsonian Science Inlormation Exchange (SSIE)

A Federal library or information center: for example. the National Agricultural Library or the Environmental Data System

The Government Printing Office (GPO)

National Technical Information Service (NTIS)

Technical Information Center at Oak Ridge (TIC)

\section{Government Solar-Involved Organizations}

Directly from the U.S. Department of Enorgy

National Solar Heating \& Cooling Information Centę

Regional Solar Energy Centers

Statc Encrgy or Solar Office

Other:

Some other state or local government office or publication

A public utility company

\section{Sources for this specific sample frame**:}

USDA, including Extension and Forestry

Bio. Enorgy Couricil

Wood Energy Institute
Percentage Responding Yes ...

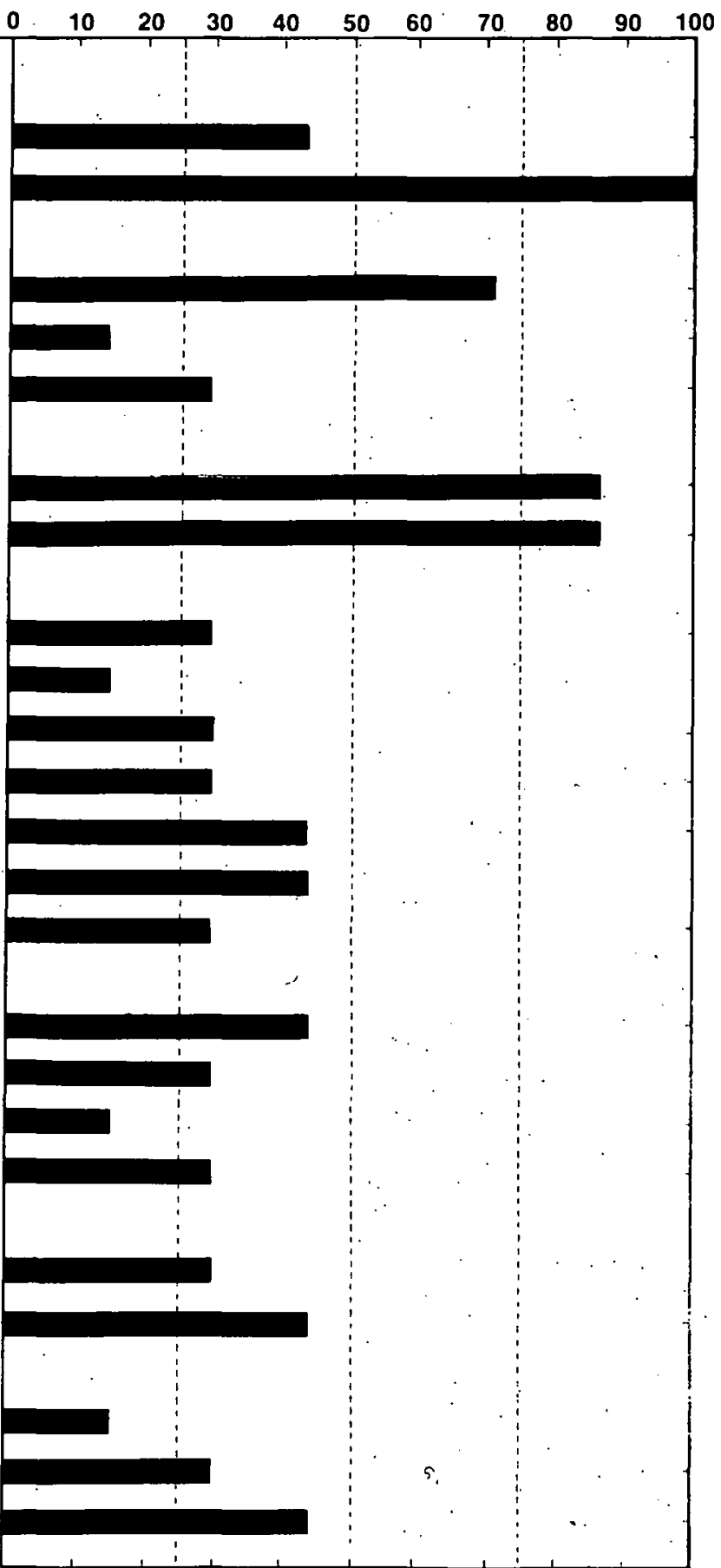

-. Scrvices and centers whose primary purnose is to disseminaie information.

Some sample frames were questioned about additional information sources which are applicable to their technology. $r$ or example. the manufacturers of biomass conversion equipment were also asked it they have obtained any type of solar information from: "the local or " nationa! olfice of the U.S. Department of Agriculture. including Extension and Forestry."

... Tliese vala are based upon a total of 7 raspondents.

Figure 10-3. Use of Selected Information Sources: Biomass System Managers 
Question \#11. In the past few years, have you obtained any type of solar information from any of the following sources?

\section{Information Sources}

Public Media:
Radio or TV
Periodicals. newspapers or magazines

Private Solar-Involved Organizations:

Private solar energy or environmental organizations

The local chapter or national headquarters of International Solar Energy Society (ISES), including their publications

The local chapter or national headquarters of Solar Energy Industries Association (SEIA), including their publications Contacis with Protessionals:

An inš̀taltèr, builder, designer or manufacturer of solar systems

Workshops, conferences or training sessions

\section{Information Services*:}

Your organizational library or a local library

A commercial data base; for example, Lockheed, SDC. BRS

Smithsonian Science Information Exchange (SSIE)

A Federal library or information center; for example, the National Agricultural Library or the Environmental Data System

The Government Printing Office (GPO)

National Technical Information Service (NTIS)

Technical Information Center at Oak Ridge (TIC)

Government Solar-Involved Organizations

Uırectly trom the U.S. Department of Energy

National Solar Heating \& Cooling Information Center

Regional Solar Energy Centers

Statc Encrgy or Solar Offices

Uther:

Some other state or local government office or publication

A public utility company

Sources for this specific sample frame**:

Your State Solar Society or Association

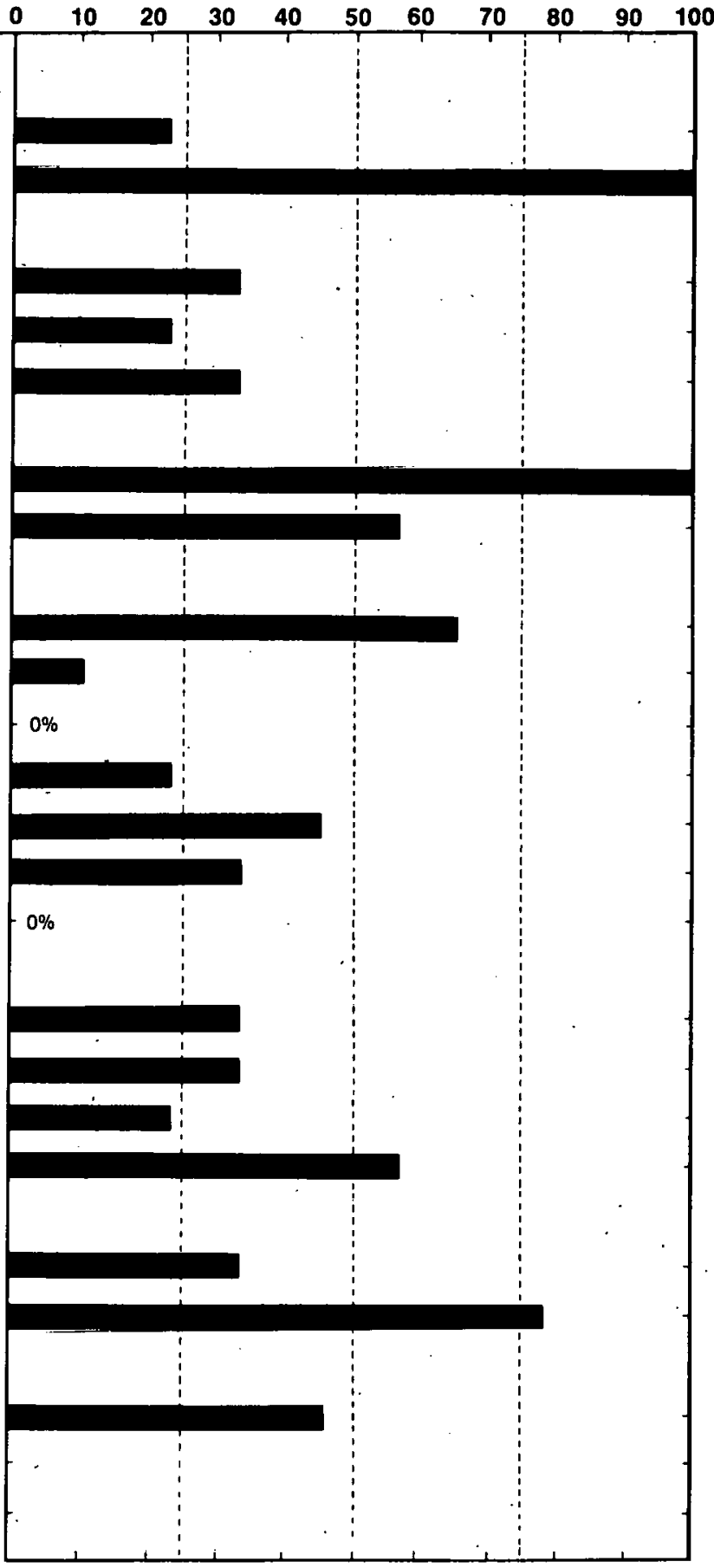

- Services and centers whose primary purpose is to disseminate information.

- Some sample frames were questioned about additional information sources which are applicable to their technology. For example, the manufacturers of biomass conversion equipment were also asked it they have obtained any type of solar information from: "the local or national office of the U.S. Department of Agriculture, including Extension and Forestry."

$\because$ These data are based upon a total of 9 respondents.

Figure 10-4. Use of Selected Information Sources: Active Solar Heating and Cooling Building Owners/Managers 
The information sources mentioned most of ten by Biomass System Managers were:

- Periodicals, newspapers, or magazines;

- An installer, builder, designer, or manufacturer;

- Workshops, conferences, or training sessions; and

- Private solar energy or environmental organizations.

The information sources mentioned least of ten by Biomass System Managers were:

- International Solar Energy Society (ISES); .

- A commercial data base;

- Regional Solar Energy Centers (RSECs);

- U.S. Department of Agriculture (USDA), including Extension and Forestry;

- Solar Energy Industries Association (SEIA);

- An organizational library or a local library;

- Smithsonian Science Information Exchange (SSIE);

- A federal library or information center;

- Technical Information Center (TIC);

- National Solar Heating and Cooling Information Center (NSHCIC);

- State energy or solar offices;

- Some other state or local government office or publications; and

- Bio-Energy Council.

Biomass System Managers did not appear to have much diversity in information sources; only 4 of the 23 sources had been used by more than half of the respondents. SHAC Building Owners/Managers also appeared to be users of a limited number of sources. Information sources mentioned most of ten by both Biomass System Managers and by SHAC Building Owners/Managers included "periodicals" and "an installer, builder, designer, or manufacturer."

\subsubsection{Membership in Solar-Interested Organizations}

Only 3 of the 7 Biomass System Managers interviewed were members of a professional, technical, or other organization with an interest in solar energy. These organizations (all receiving single mentions) included:

- American Society of Civil Engineers,

- American Textile Manufacturers Institute,

- Maine Audubon Society, and

- SEIA. 


\subsubsection{Exposure to Publications on Solar Energy}

During the past 6 months, all 7 Biomass System Managers had read publications that included information on biomass energy. The publications they could specify (and the number of times mentioned) included:

- Bio-Energy Directory,

- Energy Future (Harvard project book),

- Fortune,

- Maine Audubon Society publications (on solar energy and wood),

- Plant Energy Management,

- Plant Engineering,

- Solar Age (2),

- SEIA News (on swimming pool heating),

- Sun World;

- Textile World, and

- Wood and Wood Products.

One Biomass System Manager also menționed "SEIA Magazine," a publication which could not be verified by the authors.

\subsection{SÜMMARY AND COMMENTS}

Seven managers of biomass energy conversion systems were interviewed. Types of biomass energy systems used included: conversion of municipal waste, heat recovery, and wood by-products. Management experience with the systems included four with 1-3 years experience and three with over 3 years.

Biomass System Managers gave the highest priority to receiving information on:

- Costs of installing and operating a biomass energy system compared to a conventional system;

- Tax credits, grants, or other economic incentives for biomass energy applications;

- Cofts and performance of biomass energy systems;

- A technical description of how a particular biomass energy system works;

- A nontechnical description of how a particular biomass energy system works; and

- Biomass energy system diagrams or schematics.

They gave low ratings to "climatological data," "computer models," "marketing statistics," and "calendars."

The resulting picture of the Biomass System Manager was one whose primary information concerns consisted of economics (both costs and economic incentives) and descriptive 
information on biomass energy systems. Similarly, SHAC Building Owners/Managers also placed a high priority on cost information. In contrast to the SHAC group, however, Biomass System Managers were significantly less concerned with "lists of local lenders, (etc.)" and "local building codes."

The information sources mentioned most of ten included "periodicals," professional contacts such as "an installer, builder," "workshops, conferences," and "private solar energy" or environmental organizations." Biomass System Managers referred to a limited number of sources for information on solar energy. When asked in retrospect what would be the first thing they would do to obtain information on biomass energy, the responses varied widely and offered little consistency. 


\section{S\#PI}




\section{SECTION 11.0}

\section{REFERENCES}

1. Belew, William W.; Wood, Barbara L. Solar Information User Priority Study. SERI/TR-75 1-472. Golden, CO: Solar Energy Research Institute; May 1980.

2. Belew, William W.; Wood, Barbara L.; Marle, Terry L.; Reinhardt, Carol L.; General Solar Information User Study. SERI/TR-751-753. Golden, CO: Solar Energy Research Institute; 1981.

3. Bio-Energy Directory. Washington, DC: Bio-Energy Council; June 1978.

4. 1979 Directory of Suppliers, Manufacturers, Technical Consultants, Professional Engineers (Offering Products and Services Related to Energy Sources, Utilization and Conservation in the Forest Products Industry). Forest Products Research Society.

5. Manufacturers Data Base, Solar Energy Information Data Bank (SEIDB). Golden, CO: Solar Energy Research Institute; Spring/Summer 1979.

6. 1979 Directory of the Forest Products Industry. San Francisco, CA: Forest Industries.

7. Education Data Base, Solar Energy Information Data Bank (SEIDB). Golden, CO: Solar Energy Research Institute; Spring/Summer 1979. Also available in hard copy as the National Solar Energy Education Directory. SERI/SP-42-141. Golden, CO: Solar Energy Research Institute; January 1979.

8. County Agents Directory. 63rd Edition. Flossmor, IL: C. L. Mast, Jr. 1978.

9. County and City Data Book, 1977 (A Statistical Abstract Supplement). Washington, DC: U.S. Department of Commerce, Bureau of the Census. U.S. Government Printing Office.

10. Solar Energy Technical Information Dissemination Program. Reference Directory: Fuels from Biomass. McLean, VA: MITRE Corporation; April 1979. Update to MITRE's Reference Directory: Fuels from Biomass. McLean, VA: MITRE Corporation; June 1979 (unpublished).

11. Electric Utility Solar Energy Activities, 1978 Survey. EPRI ER-966-SR. Palo Alto, CA: Electric Power Research Institute (EPRI); May 1.979. 


\section{SEPl}


APPENDIX A

GROUPS INCLUDED IN STUDY 


\section{SEPI}


The following table (Table A-1) lists the 86 groups included in this study of solar information users. Major headings are the same as those of individual reports. Ten separate reports analyzing the study results by technology will be issued.

In general, results for each group are reported in only one volume, although comparisons to similar groups in other technologies are of ten part of the analysis. There are two exceptions: the results for Concentrating Collector Manufacturers are discussed in both the Solar Thermal Electric Power and the Industrial and Agricultural Process Heat report; the results for Nonconcentrating Collector Manufacturers are discussed in both the Active Solar Heating and Cooling and the Industrial and Agricultural Process Heat reports.

Table A-1. GROUPS STUDIRD

\section{A. PHOTOVOLTAICS}

1. DOE-Funded Researchers

2. Non-DOE-Funded Researchers

3. Researcher Manufacturers

4. Manufacturers

5. Electric Power Engineers

6. Utilities

7. Educators

\section{B. PASSIVE SOLAR HEATING AND COOLING}

1. Federally Funded Researchers

2. Manufacturers

3. Architects

4. Builders

5. Educators

6. Cooperative Extension Service (CES) County Agents

7. Homeowners with Passive Systems 
Table A-1. GROUPS STUDIED (Continued)

\section{ACTIVE SOLAR HEATING AND COOLING}

1. DOE-Funded Researchers

2. Non-DOE-Funded Researchers

3. Heating and Cooling System Manufacturers

4. Water Heating System Manufacturers

5. Nonconcentrating Collector Manufacturers (see also Industrial and Agricultural Procose Heat)

6. Other Component Manufacturers

7. Distributors

8. Installers

9. $\quad$ Architects

10. Builders

11. Planners

12. Heating, Ventilating, and Air Conditioning Engineers

13. Industrial Engineers

14. Utilities

15. Educators

16. CES County Agents

17. Homeowners with Space Heating Systems

18. Homeowners with Water Heating Systems

19. Owners/Mànagers of Buildings with Solar Heating and Cooling (SḦAC) Systems

\section{BIOMASS ENBRGY}

1. Federally Funded Researchers in Production and Collection

2. Federally Funded Researchers in Conversion

3. Nonfederally Funded Researchers in Production and Collection

4. Nonfederally Funded Researchers in Conversion 
Table A-1. GROUPS STUDIED (Continued)

D. BIOMASS ENERGY (cont'd.)

5. Production and Collection Equipment Manufacturers

6. Conversion Equipment Manufacturers

7. State Forestry Offices

8. Private Foresters

9. Forest Products Engineers and Consultants

10. Educators

11. CES County Agents

12. Owners/Managers of Biomass Systems

B. SOLAR THERMAL ELECTRIC POWER

1. DOE-Funded Researchers

2. Non-DOE-Funded Researchers

3. Concentrating Collector Manufacturers (see also Industrial and Agricultural Process Heat)

4. Electric Power Engineers

5. Utilities

6. Educators

\section{F. INDUSTRIAL AND AGRICULTURAL PROCESS HEAT}

1. Industrial Process Heat (IPH) Researchers

2. Agricultural Process Heat (APH) Researchers

3. Concentrating Collector Manufacturers (see also Solar Thermal Electric Power)

4. Nonconcentrating Collector Manufacturers (see also Active Solar Heating and Cooling)

5. Plant Engineers (IPI)

6. Industrial Engineers (IPH)

7. Private Agricultural Engineers (IPH) 
Table A-1. GROUPS STUDIED (Continued)

F. INDUSTRIAL AND AGRICULTURAL PROCESS HEAT (cont'd.).

8. Educators (IPH)

9. State Agricultural Offices (APH)

10. CES County Agents (APH)

\section{G. WIND ENERGY}

1. DOE-Funded Researchers

2. Non-DOE-Funded Researchers

3. Manufacturers

4. Distributors

5. Wind Engineers

6. Electric Power Engineers

7. Utilities

8. Eduoatore

9. CES County Agents

10. Small Wind Energy System Owners

H. OCEAN ENERGY SYSTEMS

1. DOE-Funded Researchers

2. Non-DOE-Funded Researchers

I. SOLAR ENERGY STORAGE

1. DOE-Funded Researchers

2. Non-DOE-Funded Researchers

J. GENERAL SOLAR

1. Loan Officers

2. Real Estate Appraisers 
Table A-1. GROUPS STUDIED (Concluded)

J. GENERAL SOLAR (cont'd.)

3. Tax Assessors

4. Insurers

5. Lawyers

6. Nonsolar Utilities

7. Public Interest Groups

8. CES State Agricultural Specialists

9. CES State Information Specialists

10. State Energy/Solar Offices (Western SUN states)

11. State Energy/Solar Offices (MASEC states)

12. State Energy/Solar Offices (NESEC states)

13. State Energy/Solar Offices (SSEC states) 


\section{SERI}


:

APPENDIX B

STUDY DEVELOPMENT AND PROCEDURE 
SERI㐘 
This Appendix describes several aspects of the way in which the studies were developed and conducted.

\section{FACTORS IN STUDY DESIGN}

Studies of $\mathbf{8 6}$ groups, each interested either in one of nine different solar technologies or in solar energy in general, provided an extremely broad view of the information needs of the solar community. Although the sample size of nine respondents per group was small, the data still proved to be quite adequate for planning purposes. It was possible to determine which information was the most important to the respondents and what was the best channel for disseminating that information. There were a number of valid statistical tests that could be made, both to compare the priorities a group gave to different information items and to compare the priorities different groups gave to the same item.

Several major factors resulted in the decision to conduct a study with these characteristics. First, there were very few data available on the information needs and information-acquiring activities of the various segments of the solar community, and those data that did exist were related almost exclusively to the area of active solar heating and cooling (SHAC). Many people had strong opinions as to which information products should be developed first, but data obtained directly from the information users was virtually nonexistent. Due to this general lack of information, most of the potential users of the findings of these studies could not define highly specific questions that they needed to have answered by these studies. Instead, baseline data was needed. It did not make sense to ask a researcher detailed questions on whether he needed a calendar of solar events to be updated monthly or updated quarterly, when no one knew whether he even needed calendars at all. Thus, the lack of baseline data dictated that most of the potential users of study findings framed their questions at the level of "What information do you need the most?" For such a level of questions there was obviously no great need to use large sample sizes to obtain extremely precise, quantitative answers. Since qualitative data would be quite adequate, there was no need for a large sample size.

Further, there was a need to obtain this baseline data as rapidly as possible so that realtime programmatic decisions about development of information products and data bases could be based upon data rather than conjecture. As a result, the decision was made to conduct the studies by telephone in an attempt to speed up the data collection process. Interviewing by telephone also had the result of improving the response rates (over those using a mail questionnaire).

Thus, these factors dictated the final study design: a broad-based study (the final number of groups studied, 86, was determined primarily by the number of meaningful sample frames that could be constructed) to collect qualitative data by obtaining completed telephone interviews, with approximately nine randomly selected respondents from each of the 86 groups being interviewed.

\section{Impact on Questionnaires}

As a result of using telephone interviews to conduct the studies, it was necessary to limit the number of questions to be asked: Telephone interviews had to be kept relatively short (preferably under twenty minutes) to keep the respondents from prematurely terminating the interview. Even if a respondent did not hang up in mid-questionnaire, his attention span could be tried severely by lengthy interviews; respondents would then 
answer questions without much thought in order to terminate the interview as rapidly as possible. In the final study the interviews took an average of about 18 minutes to complete (with a range from 10 minutes to 50 minutes) and incorporated very simple question formats, sometimes open-ended questions. For each of the 86 studies a separate and distinct sample frame, letter of introduction, and questionnaire were developed and separate computer runs and analyses were performed.

Perhaps a more important effect of deciding to do a telephone study was the necessity of using interviewers without solar backgrounds to conduct the study. With almost 800 interviews to be conducted, each requiring an average of 35-40 minutes to complete an 18-minute interview (due to callbacks, referrals, busy signals, wrong numbers, etc.), there was too much effort required to conduct the interviews using internal staff. Thus, the effort had to be contracted. The choice was whether to conduct the interviews by contracting solar experts (who would not know anything about interviewing techniques) or by contracting a professional telephone interview firm (whose interviewers would not know anything about solar energy). Due to the significantly lower cost and to the significantly reduced chance of biasing the responses, it was decided to use a professional telephone interview firm.

As a consequence of this decision, there were some problems caused by using nonsolar interviewers to pose questions of solar experts. If a respondent asked for a question to be clarified, the interviewer could not assist. Instead, the interviewer could only repeat the question. The biggest problem involved the open-ended questions. Sometimes the interviewer simply did not understand what the respondents were talking about. Interviewers were briefed in solar terminology and instructed to ask respondents to spell out words the interviewers did not understand. Nevertheless, some of the verbatims (i.e., quotes from the respondents that were copied down verbatim by the interviewers) were not intelligible. For example, one interviewer recorded "small square train feeders" when the respondent really said "small-scale terrain features," another recorded "nel lenses" instead of "Fresnel lenses." To minimize errors in translation, all of the questionable verbatim items listed in this report were reviewed and verified by Solar Energy Research Institute (SERI) technical experts. However, based upon listening to live interviews and comparing the results to the verbatims, usually the interviewers were able to transcribe the salient points of the responses.

\section{Impact on Statistical Characteristics}

The sample size of nine respondents per group was limiting for the analyst. To illustrate the lack of precision in the results, if five of the nine respondents answered "yes" to a particular question, there was a 95\% chance that the true proportion saying "yes" was between 0.212 and 0.862 . Obviously, this was an extremely wide confidence interval. For such a small sample size, it was not feasible to make national estimates (e.g., the number of federally funded biomass production and collection researchers in the country who need bibliographies), and it was not meaningful to construct cross-classification tables (e.g., "type of information needed" versus "degree of informedness"). Because of these small sample sizes, the authors were sometimes forced to propose hypotheses rather than draw conclusions.

Nonetheless, the results were extremely useful when taken as qualitative, baseline results. Certain statistical tests could still be performed (see Appendix E). One could test whether Biomass Researchers wanted "the state-of-the-art" information significantly more than they wanted "marketing statistics." Several tests could be made 
comparing one group with another. Thus, one could test whether Biomass System Managers wanted cost data significantly more than did SHAC Owners/Managers. This type of comparison usually highlighted basic differences between technologies. One could also test whether Biomass Researchers responded differently from All Researchers.

Comparisons of this type were valuable for several reasons. First, they allowed the comparison of the information needs of a relatively unknown group against those of a more familiar group. For example, the information needs of Biomass Manufacturers were easier to understand when compared to the more familiar information needs of SHAC Manufacturers.

Second, if one can establish basic similarities in information habits and the types of information needed, it will eventually become possible to use the results of other information science studies. For example, many studies have detailed the types of information researchers need and the ways of getting information to them. Thus, if Biomass Researchers were quite similar in needs to All Researchers, it was an indication that many of the well-known findings for researchers in general may also apply for Biomass Researchers.

\section{STUDY DEVELOPMENT}

There were several tasks which had to be completed before the studies could be conducted. These tasks are described in the following subsection.

\section{Development of Sample Frames}

Sample frame development was the single most difficult, time-consuming task in the entire study. As discussed in Section 2.2, the initial attempt was to obtain lists of the names, addresses, and phone numbers of members of as many meaningful groups as possible. A total of about 86 such sample frames was the maximum that could be developed adequately within a reasonable amount of time.

The services of reference and research librarians were used in this process, much of it on a subcontractor basis. Over 200 documentary sources (printed, published and unpublished sources, and dutu buses) were consulted. Staff searched the Solar Energy Information Center and Denver-area public and academic libraries to examine directories, catalogs, periodicals, and data bases. Directories of professionals, organizations and associations, and solar-related individuals and groups were examined, both to obtain sample frames and to obtain individual names. Periodicals were searched both to identify associations whose members might be eligible for sample frames and to identify authors who could be contacted because they represented certain target groups. Various data bases were identifed which contained names of individuals, categorized by sample frame categories (e.g., educators, researchers, manufacturers). Lists of conference attendees were accumulated. Sample frames were also constructed by establishing numerous personal contacts with professional, technical, and special interest organizations; authors of solar articles; technical staff at SERI; federal offices; publishers; solar groups; at least 30 state solar and state energy offices, etc.

Both the Mid-American Solar Energy Complex and the Northeast Solar Energy Center were subcontracted to provide additional names and uddresses. Western SUN also provided many names on a voluntary basis. The Southern Solar Energy Center was asked 
to participate on either a contractual or a voluntary basis, but declined. Additionally, the Technical Information Dissemination (TID) program subcontracted a consulting firm to develop lists of members of the solar community. Although the resulting lists were significantly smaller than had been anticipated, they provided valuable backup information for some sample frames. The National Solar Heating and Cooling Information Center provided several of the data bases and other lists used.

It sometimes occurred that the person contacted was not in the presumed field; for example, an installer was no longer involved with solar energy. The proportion of the time that this or a similar sample-frame error occurred has been calculated for each group and is included in the section documenting the results for the group. Sample frame error included such factors as no known telephone number, individual not in the specified field or employment sector, etc. Averaging over all groups, 20\%-25\% of the candidates in the sample frames were no longer valid.

\section{Pilot Testing}

In August 1979, Market Opinion Research (MOR) conducted a pilot test by doing telephone studies of 10 groups ( 9 respondents for each). The groups were:

- Wind: Engineers,

- Wind: County Extension Agents,

- Active Solar Heating and Cooling: DOE-Funded Researchers,

- Active Solar Heating and Cooling: Installers,

- Active Solar Heating and Cooling: Utilities,

- Active Solar Heating and Cooling: Educators,

- Active Solar Heating and Cooling: Commercial Building Owners,

- Passive Solar Heating and Cooling: Equipment Manufacturers,

- Solar Industrial Process Heat: Industrial Engineers, and

- General Solar Energy: Lawyers.

These groups were selected specifically to test a range of questionnaires, the peculiarities of selected sample frames, and the receptiveness of certain target groups to telephone interviews on solar energy. The persons contacted in the pilot were not contacted in the full study.

The pilot test proved very useful. There were no major revisions resulting, but several refinements improved the interview procedure and the questionnaire content and format. The interviews were completed within a reasonable time, an average of about 18 minutes per interview. The most important finding of the pilot test was the enthusiasm of the respondents for solar energy. Most respondents were very cooperative and were excited about receiving solar information. Because of this attitude, interviewers had no difficulty in getting respondents through long lists of information products and sources or in keeping respondents on the telephone to finish the interview.

SERI personnel visited MOR while the pilot test was being conducted, personally participating in monitoring interviews, reviewing tape recordings of previously conducted 
interviews, and debriefing interviewers. Based upon these inputs, several changes were made in the basic questionnaire concept, resulting in changes for each of the 86 distinct questionnaires. Among these changes were: addition of a question designed to defuse the respondent by allowing expression of the respondent's individual concerns, deleting two questions which were not working, changing the sequence of a few questions, making a few small wording changes to sharpen questions, and changing MOR's suggested questionnaire format in order to minimize interviewer errors.

Upon realizing that there was more sample frame error than had been anticipated, the screening procedure was revised to a double screening procedure; only people who said they needed solar information within the next year, and who were truly in the proper group (e.g., "an educator teaching biomass courses") were to be interviewed. The rules for handling referrals were revised to allow interviews with intraorganizational referrals only.

Perhaps the most important change was in the interviewer training procedure. More specific instructions were developed for each question so that the interviewers would know the real point of the question, would ask the question properly, and would know what to emphasize. Lists of words being mispronounced by the interviewers were developed. Specific interviewers with pronunciation problems were singled out for additional coaching. Because of the interviewers' lack of familiarity with solar energy terminology, glossaries and other background information on solar energy were provided to interviewers.

\section{Interviewer Training and Monitoring}

The MOR interviewers used for these studies were all experienced interviewers. They went through three separate training sessions: a pilot test briefing, a pilot test debriefing (with question and reaction session), and a full study briefing. The full study briefing was held in four separate sessions so that the interviewers could be trained in small groups. SERI representatives were present for and assisted with the second two sessions.

These training sessions covered the purpose of the study, question wording, recording procedures, the screening procedure, and pronunciation of unfamiliar words. The training was built around the use of an annotated briefing questionnaire. Notes concerning each question were. written on a questionnaire which the interviewer studied during the briefing. Additional written materials covered included a list of solar energy terms, a list of common solar acronyms, and a list of words for pronunciation reminders.

\section{Randomized Selection of Respondents}

Once the sample frames were developed for each group, a random sample of 30 to 40 potential respondents was drawn by systematic sampling. (If the sample frame for a group only had 30 to 40 names in the beginning, this step was omitted.) These reduced sample frames were then forwarded to MOR. At MOR, these randomly selected names were put through a second randomization process which assigned the order in which these names were to be called. The MOR process used systematic sampling to identify the first nine candidates for interviewing; the total number of potential candidates was divided by nine to obtain " $i$," the "skip interval." Starting from a random point (R), every $i^{\text {th }}$ name then became one of the first nine candidates. 
An initial call and up to two callbacks (at different times of day on different days of the week) were made, attempting to reach each designated respondent. If an interview was not completed after three attempts, the interviewer took the questionnaire to the interviewing supervisor. The supervisor then designated the next person in the sequence as the substitute candidate: if the $(R+i)^{\text {th }}$ person could not be reached, the $(R+i+1)^{\text {th }}$ became the replacement candidate. If after three attempts to reach the substitute, no interview was completed, this process was repeated. (This time the $(R+i+2)^{\text {th }}$ person would become the candidate, etc.) For the entire study, 54\% of the completed interviews were with the originally designated respondent and $26 \%$ were with the first substitute. The remainder were completed with a second or higher substitute.

There is evidence that for some sample frames MOR did not use a random starting point to commence the skip interval, but instead used the sequence of $1^{s t},(1+i)^{t h},(1+2 i)^{\text {th }}$, etc., names for initial candidates. Such a practice clearly does not conform to professional standards. 'This practlce was not critical in those sumple frames with a large initial size or no particular order, since SERI did a valld random subsampling to reduce the sample size to 30 or 40 . In small sample frames or in frames with a definite pattern, however, this procedure could have caused biases. All seven of the Coopcrutive Extension Service (CES) sample frames were arranged in a state-by-state order. As a result of not randomly changing the starting point, there was a strong tendency towards sampling from the same states for these sample frames. The final distribution of CES respondents by state is shown in Table B-l. Some clustering did occur for some states. Thus, for these groups results were geographically biased.

\section{STUDY PROCEDURE}

The procedure was the same for each study. Each of the potential respondents was sent a letter of introduction one to three weeks before they were telephoned (see Appendix C). This letter explained that the person was selected as a candidate and may be called by MOR, that MOR was calling for SERI, the purpose of the call, the type of informution being sought, and that the respondent's identity would be kept confidential.

The telephone interviews were conducted in one of MOR's two telephone rooms, with each individual interviewer in an acoustically insulated booth. Throughout the study, interviews were monitored by MOR's phone room supervisors. They were responsible for randomly listening to interviews to determine whether the operators were conducting the interviews correctly. If mistakes were being made, the supervisor explained the proper procedure to the interviewer. The supervisors were able to monitor calls without the interviewers knowing they were being monitored.

Candidates were telephoned during business hours (except for homeowners who were called during the early evening and weekends). If the interview cundidate could not be contacted in the initial call, as many as two additional callbacks were made. These callbucks were made at different times of the day and on different days of the week. If no interview was completed after three attempts, a substitute candidate replaced the initial candidate and the process started over. If a secretary indicated the candidate would be in later at a specified time and day, the callback was scheduled correspondingly. If a candidate was too busy to talk when initially contacted, an appointment was made to call back at a specified time. Only $3 \%$ of the candidates contacted refused to be interviewed or terminated the interview before it was completed. Once a candidate was contacted, a screening procedure was used to verify that the respondents being interviewed actually represented the group to which they ostensibly belonged. For example, a respondent who 
Table B-1. COOPERATIVE EXTENSION SERVICE (CES): STATES

REPRESENTED IN SAMPLES ${ }^{a}$ (Number of Respondents)

\begin{tabular}{|c|c|c|c|c|c|c|c|c|c|c|}
\hline \multirow{2}{*}{ State } & \multicolumn{6}{|c|}{ County Agents } & \multicolumn{3}{|c|}{ State Specialists } & \multirow[b]{2}{*}{$\begin{array}{c}\text { All } \\
\text { CES }\end{array}$} \\
\hline & $\begin{array}{l}\text { Bio- } \\
\text { mass }\end{array}$ & Wind & $\mathbf{A P H}$ & $\begin{array}{l}\text { Pas- } \\
\text { sive }\end{array}$ & $\begin{array}{l}\text { Ac- } \\
\text { tive }\end{array}$ & Total & $\begin{array}{l}\text { Infor- } \\
\text { mation }\end{array}$ & $\begin{array}{l}\text { Agricul- } \\
\text { tural }\end{array}$ & Total & \\
\hline Alabama & - & 1 & - & 1 & - & 2 & - & - & - & 2 \\
\hline California & - & 1 & - & - & - & 1 & - & - & - & 1 \\
\hline Colorado & - & 1 & - & - & 1 & 2 & - & - & - & 2 \\
\hline Connecticut & - & - & - & - & - & - & 1 & - & 1 & 1 \\
\hline Delaware & - & - & - & - & - & - & - & 1 & 1 & 1 \\
\hline Georgia & - & - & - & 1 & - & 1 & - & - & - & 1 \\
\hline Idaho & - & - & 1 & - & - & 1 & 1 & 1 & . 2 & 3 \\
\hline Illinois & - & 1 & - & - & - & 1 & - & - & - & 1 \\
\hline Indiana & 2 & 1 & 一. & 1 & 1 & 5 & - & - & - & 5 \\
\hline Iowa & - & 1 & - & - & - & 1 & - & - & - & 1 \\
\hline Kansas & - & - & 2 & - & 1 & 3 & - & - & - & 3 \\
\hline Kentucky & - & 1 & - & 1 & - & 2 & 1 & 1 & 2 & 4 \\
\hline Louisiana & - & - & - & - & - & - & 1 & - & 1 & 1 \\
\hline Maryland & 1 & - & - & - & - & 1 & - & - & - & 1 \\
\hline Michigan & - & 1 & - & - & - & 1 & 1 & 1 & 2 & 3 \\
\hline Minnesota & - & - & - & 1 & 1 & 2 & - & - & - & 2 \\
\hline Missouri & - & 1 & - & - & - & 1 & - & - & - & 1 \\
\hline Montana & 1 & - & - & - & 1 & 2 & - & 一 & - & 2 \\
\hline Nebraska & - & - & 1 & 1 & $\overline{1}$ & 3 & 1 & 1 & 2 & 5 \\
\hline New Mexico & 1 & - & - & - & - & 1 & - & - & - & 1 \\
\hline New York & - & - & - & - & - & - & 1 & 1 & 2 & 2 \\
\hline N. Carolina & - & - & 1 & 1 & 一 & 2 & - & - & 二 & 2 \\
\hline Ohio & 1 & - & - & - & 1 & 2 & - & - & - & 2 \\
\hline Oklahoma & - & - & 1 & - & - & 1 & 1 & - & 1 & 2 \\
\hline Oregon & 1 & - & - & - & - & 1 & - & - & - & 1 \\
\hline S. Carolina & - & - & - & - & - & - & 一 & 1 & 1 & 1. \\
\hline S. Dakota & - & - & 1 & 1 & 1 . & 3 & 1 & - & 1 & 4 \\
\hline Tennessee & 1 & - & 1 & 1 & - & 3 & - & - & - & 3 \\
\hline Texas & 1 & - & 1 & - & 1 & 3 & - & 1 & 1 & 4 \\
\hline W. Virginia & - & - & - & - & - & - & - & 1 & 1 & 1 \\
\hline \multirow{2}{*}{$\begin{array}{l}\text { Sample Size } \\
\text { by Technology }\end{array}$} & & & & & & & & & & \\
\hline & 9 & 9 & 9 & 9 & 9 & 45 & 9 & 9 & 18 & 63 \\
\hline \multicolumn{11}{|l|}{ Total States } \\
\hline Represented & 8 & 9 & 8 & 9 & 9 & 24 & 9 & $\dot{\mathbf{y}}$ & 13 & $30 *$ \\
\hline
\end{tabular}


was presumably an educator teaching courses in biomass was read the following statement at the beginning of the interview:

Hello (respondent's name). This is (interviewer's name) of Market Opinion Research. A week or so ago you were sent a letter from the Solar Energy Research Institute describing a study of solar energy information needs and requesting your participation.

Your name has been provided to us as someone who has been teaching courses related to biomass. Is that correct?

If the respondent answered "yes," the interview continued. If the respondent answered "no," then the respondent was not interviewed but instead was asked if there was another person within the same university who was teaching courses related to biomass energy. If the initial candidate could give the name of another person, the referral person (or "referraili) was called as a substitute for the initial candidate. If no intraorganizational referral was given, another candidate was telephoned.

A second screen was used to eliminate those people who did not feel they would be needing information in the near future. For example, biomass respondents were asked the following two questions:

- In the next year do you expect to need information on biomass systems for your job?

- In the next year do you expect to need information on biomass systems outside your job?

For all respondents other than Biomass System Managers, these questions were asked at the beginning of the interview and if the answer to both questions was "no," the interview was terminated and a substitute candidate telephoned. No request for a referral was made.

Once an interview was completed, the questionnaire was reviewed for completeness by the phone room supervisor. Incomplete questionnaires were returned to interviewers to recall the respondents.

Completed questionnaires were forwarded from the phone rooms to the Coding Department where they were checked in and assigned a unique identification number. They were subsequently sent to the Data Entry Department where they were keyed directly into computer data files. Since no computerized editing system could prevent the Incorrect entry of a data value that was within the proper range (e.g., entering a "3" when the correct number was a "2" but where the numbers "1," "2," " 9 ," and "4" ale all valid numbers), SERI did a random sample of supposedly correct values to verify that they were correct. Out of 225 allowable values reviewed, only 1 had been incorrectly entered. Once the data were entered on the computer file, data tables were printed and analyzed.

Nonuniform Group Sample Size. The study was originally designed to sample nine respondents from each group. For most groups this was done correctly. Upon analysis of the completed questionnaires, however, it was sometimes apparent that a respondent obviously belonged in a group other than the one in which originally sampled. This was generally due to two simultaneous errors: a sample frame error and a screening error. 
First, the person was included on the wrong sample frame. For example, a person listed as doing non-DOE-funded research could have received DOE funding af ter the sample frames were completed. Second, the screening process did not successfully remove this person from the Non-DOE-Funded Researchers; instead the interview was completed. During the interview the respondent mentioned that he was receiving DOE funds for his research. As a result the analyst received eight interviews completed with Non-DOEFunded Researchers and one completed with a DOE-Funded Researcher.

For such cases, the dissimilar interview was removed from the original group (in the example above, the Non-DOE-Funded Researchers). If there was another group into which that interview naturally fit (above, the DOE-Funded Researchers), the interview was included with the interviews for the second group. Although the added interview did not have exactly the same probability of selection as did the original interviews, the resulting inaccuracy was minimal given the qualitative nature of the data. 
SEP1 
APPENDIX C

LETTER OF INTRODUCTION 


\section{S=P1}


All potential respondents from the initial sample frames were sent the following letter (see Fig. C-1) from one to three weeks prior to being contacted by telephone. There are three phrases (underlined in this example) which were changed to describe the group and the solar technology. For example, "a researcher" was changed to read "a manufacturer" or "an educator," etc., as appropriate for the specific sample frame. Similarly, "passive solar heating and cooling" read "photovoltaics" or "wind energy systems," etc., according to the technology about which this potential respondent was to be interviewed. About 3,500 such letters were mailed over a period of several weeks. Less than 100 were returned as undeliverable.

It should be noted that in cases where the actual respondent was a referral, the respondent had not necessarily received this letter.

There were numerous telephone calls to the Solar Energy Research Institute (SERI) from people who had received this letter. Most volunteered they were eager to participate (and concerned that they had not yet been called) or that they wanted study results. A few volunteered referrals or gave the best times for them to be called. 
September, 1979

Dear Colleague:

The Solar Energy Research Institute (SERI) is currently developing a Solar Energy Information Data Bank (SEIDB). The SEIDB is designed to include many categories of solar information and will serve the needs of a variety of groups: among them, researcher's, manuf acturers, architects, builders, lawyers, and hom eowners. Services provided to you by the SEIDB may include an inquiry response service, computer access to models or large sets of data and free brochures, handbooks, etc.

The U.S. Department of Encrgy has defined solar cncrgy as cncompassing technologies which involve both direct and indirect uses of sunlight; information for all of the following technologies will be included in the SEIDB:

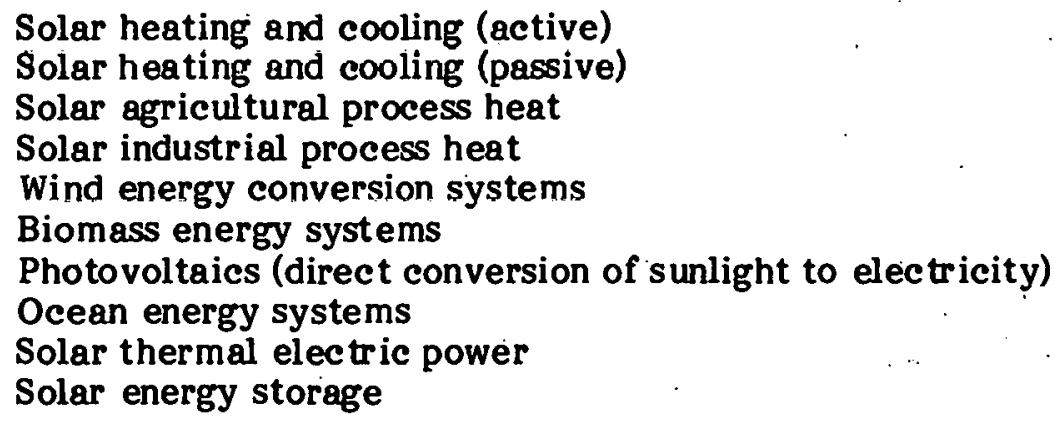

So that this data bank can be developed to meet your present or future solar information needs, SERI is surveying information users like yourself. You have been selected as a candidate for this interview because you are a researcher with an active or potential interest in passive solar heating and cooling.

We believe your participation in this survey will be beneficial to you and to the country. If called, you will have an opportunity to express your opinions and to define your solar information needs. This will help us ensure that the data bank will be responsive to the needs of researchers as well as those of other groups.

Market Opinion Research of Detroit, Michigan, has been chosen to conduct this survey for SERI. A trained interviewer may contact you within two weeks to interview you. The telephone interview will last no more than 20 minutes. You can be assured that your responses to this survey are strictly confidential. No names will be used in reporting the results.

If you have questions about this survey, its puppose, or the interview methods to be used, please feel free to contact me at (303) 231-1155. Thank you for your assistance.

Sincerely,

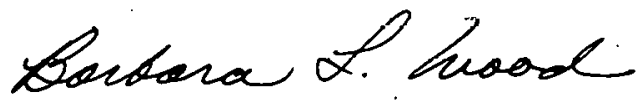

Barbara L. Wood,

Staff Market Research Infor mation Specialist, Inf ormation Disse mination Branch, Information Systems Division

Figure C-1. Letter of Introduction 
APPENDIX D

STUDY QUESTIONNAIRE 


\section{SERI噒}


A different questionnaire was developed for each distinct group in this study. These questionnaires were very similar, however, in that the same type of information was being sought from each of the groups. The individual questionnaires were developed by constructing a core questionnaire, then making appropriate revisions, additions, and deletions to produce a distinctly tailored questionnaire for each group.

Two sample questionnaires are provided in this appendix. A version of the first (Fig. D-1) was used for all samples except for users of solar systems (homeowners; building plant owners/managers). The second (Fig. D-2) was used only for users. The basic difference is that phraseology was changed for users so that their queries were related to information about the period of time their system was being considered for purchase or was under construction. The question numbering system for the user questionnaire follows that of the standard core questionnaire, although the sequence does not. For example, question $\mathrm{Bl}-6 \mathrm{a}$ of the user questionnaire is similar to question $6 \mathrm{a}$ of the standard core questionnaire.

The questionnaires used in the biomass technology studies were very similar to those used for the other studies. The two instruments which follow (see Figs. D-1 and D-2) contain references to biomass technologies in Questions 1 through 9. Questionnaires that were used for respondents from other technologies substituted references to their appropriate technologies instead of to biomass technologies.

Certain variations were made in the biomass technology questionnaires for different biomass technology groups in Questions $8 a, 8 b$, and 11 , in that certain items were not asked of groups if the item seemed inappropriate. For example, Biomass Researchers were not asked Question 8b (11) about "how to market," and Biomass Forest Products Engineers/Consultants were not asked Question 11 (7) about Smithsonian Science Information Exchange. While it would have been less complicated to have all questions asked of all respondents, concern over questionnaire length and the desire to avoid asking questions that were not relevant to the group led to deleting questions wherever possible. Questions that were not asked of each group may be noted in the data tables (Appendix F) whenever an individual group shows no entries for that item. (Variations for user questionnaires are addressed below.)

Slight variations in wording were made on the questionnaire of each individual group. For example, in Question 11(3), which asked if information had been obtained from "an installer, builder, designer, or manufacturer," the phrase "outside of your own organization" was inserted for Biomass Production and Collection Equipment Manufacturers.

\section{Standard Core Questionnaire}

Question 5. This question asked, "What is the most important information that could be provided to you about biomass energy?" This question allowed respondents to volunteer the information need that came to mind spontaneously, without reflecting any of the biases of the questionnaire designers as to what was the most important. Most of the time, however, it did not result in an answer which could be compared to another respondent's answer; for nine respondents, there were typically seven or eight distinct answers given. Since each respondent did not rate these items, it was impossible to determine which of these information needs was the most important. Afforded a second thought, respondents often gave items they had mentioned as "most important" in Question 5 a lower rating in Question 8 than they gave to items that they had not even mentioned in Question 5. As a result, the data from Question 5 could not provide a valid measurement of the most important information items which could be provided to the respondent. 
In the next year, do you expect to need information on biomass energy? (a) For your job? Yes..... T T T

Don't know. . . .8

iNA. ...... .9

(b) Outside of your job?

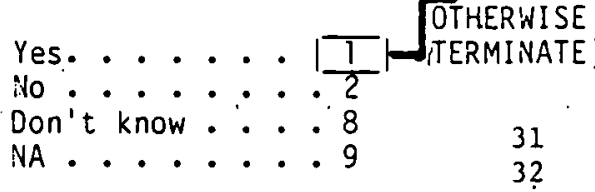

To what extent are you currently involved with biomass eneruy s.yșțents? Would you say you are:
Very involvert. . . . . . , . . . .4

Moderately involved $n r . . .3$

Slight ly involved. . . . . . . . . 2

Not at all involved (VOIIINTEERE[). .1

Don't know. . ...... 8

NA. ............. 9

- . What are you doing in the field of biomass energy? (ASK AS OPEN END)

Verb.

How well informed would you say you are about biomass energy systems? Would you say you are:
Very informed. . . . . . . . 4 Moderately informed or . : : . 3 Slightly informed .......? Not at all informed (VOLUNTEERED). . 1 Don't know:.......... 8

NA. . . . . . . . . . . . . 9

What is the most important information that could be provided to you about biomass energy? (INTERVIEWER: THIS INCLUDES INFORMATION INHICH COULD BE PROVIDED BY AN INFORMATION CENTER)

lst mention

$C+V$

2nd mention 
6. For which of. the following areas of biomass energy are you particularly interested in obtaining information? [READ LIST. CIRCLE ONE RESPONSE PER ITEM : ]

(1) Growth or collection of biomass materials

(2) Liquid fuels from biomass materials

(3) Gases from biomass materials.

(4). Burnable pellets, etc., from biomass - materials

(5) Residential burning of wood Yes No Know NA

(6) Cominercial or industrial burning of wood, agricultural residues, or inunicipal wastes

$1 \quad 2 \quad 8$

9

Are there any other areas of biomass energy for which you are especially interested in obtaining information?

(SPECIFY).

(1st Mention)

(2nd Mention)

\section{What publications have you read in the past six months that include information on biomass energy?}

1st Mention
None. . . . . . . . . 001

Read, but can't remember titles 002 (VOLUNTEERED)

Rcad too many to name (VOLUNTEERED) ......003 $52-54$ (ASK) Which are most important? (RECORD IITLES)

- Names publications

(RECORD IITLES) $\cdots \cdots \cdot . \cdot 004$

\section{2nd Mention}


8a. I will read a list of potential information products on biomass energy.

For each, please tell me how useful that information would be to you. Would the following be: essential, very useful, somewhat useful, or not at all useful? [READ LIST. ROTATE. CIRCLE ONE RESPONSE PER ITEM]

Not

Essential Useful $\begin{gathered}\text { Very } \\ \text { Useful } \\ \text { Useful }\end{gathered}$ 年ow

(1) A bibliography of yeneral readings on biomass energy systems. ... 4

3

5

3

2

8

$9 \quad 43$

(2) A list of sources for information on particular biomass energy systems . 4

(3) A calendar of upcoming biomass energy conferences and programs. . 4

3

2

3

4

3

4

3

\section{4}

3

2

1

3

$9 \quad 49$

(8) Biomass energy system design handbooks, installation handbooks ur reference lables. . . .

3

2

$$
\dot{8}
$$

y su

(9) A list of technical experts in a specific area of biomass energy. . . 4

(10) Manual methods for sizing and predicting the engineering performance or life cycle costs of biomass energy systems. . . . :

$$
2
$$

(11) Computer models for sizing and predicting the engineering performance or life sycle costs...

1


Cd 1

8b. I will next read a list of types of information on biomass energy. For each, please tell me how useful information of that type would be to you. Would the following be: essential, very useful, sonewhat useful or not at all useful? [READ LIST.

ROTATE. CIRCLE ONE RESPONSE PER ITEM]

$$
\begin{array}{ccc}
\text { Very } & \text { Somewhat At All Don't } \\
\text { Essential Useful } & \begin{array}{c}
\text { Someful } \\
\text { Useful }
\end{array} & \text { Unow NA } \\
\hline
\end{array}
$$

(1) Educational institutions and other organizations offering courses on

bionass energy....

4

(2) Biomass energy system research

currentiy in progress. . .

4

(3) The state-of-the-art in biomass

energy systerns.....

4

(4) Costs and performance of biomass

energy installations....

(5) Costs of installing and operating a biomass energy system compared

to a conventional system. . .

(7) Tax credits, grants, or other economic incentives for biomass energy

applications...

(8) Standards, specifications, or certification programs for biomass energy equipment and installations.... 4

(9) Marketing statistics and sales projections for biomass production, collection or conversion equipment 4

(10) Biomass energy systems programs, research, industries and markets outside the United States. . .

69-75B (11) Information on how to market and. sell biomass energy systens,

77-80 Job \# including guidelines on obtaining

financial support. ...

(12) Institutional, social, environmental, and legal aspects of biomass energy applications. . .

(13) Expected major developments in biomass energy applications during the next ten years. . ...

(14) Climatological data such as wind, weather, amount of sunshine, rainfali, or data on soils. . 
9. Is there biomass energy information Yes ............ which you need but are not able to get?

Yes (BUT CAN'T DESCRIBE)..... 2

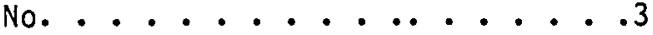

Don't know.......... 8

NA. ................

(IF YES) What information do you need?

lst mention

Verrl.

ind mention

10.' In the past year have you obtained any information, not just biomass or solar, in the following forms? [READ LIST. CIRCLE ONE RESPONSE PER ITEM.]

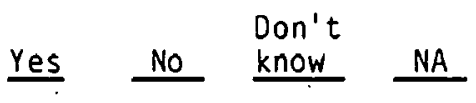

(a) On-line access to a central data bank via computer terminal

$12 \quad 2 \quad 8 \quad 9$

(b) Microform from a computer, sometimes referred to as $\mathrm{C}-0-\mathrm{M} \quad 1 \cdot 2 \quad 8$

(c) Other microforms, for example, microfiche, microfilm sheets or rolls

128

9

Figure D-1. Questionnaire (continued) 
Cd 4

11. Solar information refers to information about any solar technology, and factors which may relate to its use such as weather, economics, legislation, architecture, environment, etc. In the past few years, have you obtained any type of solar information from any of the following.sources? [READ LIST. CIRCLE ONE RESPONSE PER ITEM.]

(1) Your organizational library or a local library. . Yes No Know NA

(2) A public utility company. $12 \quad 8 \quad 9$

(3) An installer, builder, designer or manufacturer of solar systems. .

(4) Workshops, conferences or training sessions. . $1 \quad 2 \quad 8 \quad 9$

(5) A commercial data base, for example, Lockheed, SDC, BRS. . 1 2 492

(6) A Federal library or information center, for example, the National Ayricultural Library or the Environinental Data System. .

(7). Smithsonian Science Information Exchange (SSIE) : . .

(8) The Government Printing office (GPO) . . .

How would you evaluate the service you received from GPO?

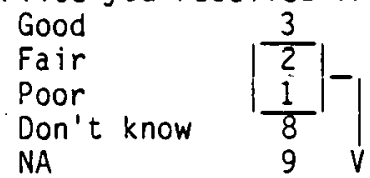

What are some of the reasons you do not consider their service "good"?

lst Mention

2nd Mention

(9) National Technical Information Service (NTIS)......
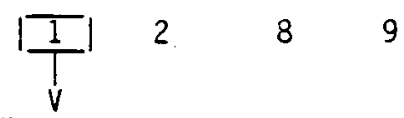

26

\begin{tabular}{|l|}
\hline How would you evaluate the service you received from itIS? \\
Good \\
Fair \\
Poor \\
Dül k knuw \\
NA
\end{tabular} \mid


(Cont'd)

Technical Information Center at 0ak Ridge (TIC) . . .

Yes $\frac{\text { No }}{2} \frac{\begin{array}{l}\text { Don't } \\ \text { know }\end{array}}{8} \frac{\text { NA }}{9}$

How would you evaluate the service you received from TIC?

\begin{tabular}{l|l} 
Good \\
Fair \\
Poor \\
Dun'l l knuw \\
NA
\end{tabular}$\left|\begin{array}{c|}\frac{3}{2} \\
\frac{1}{8} \\
9\end{array}\right|$

What are some of the reasons you do not consider their service "good"?

lst Mention

2nd Mention

(11) National Solar Heating and Cooling Information Center. .

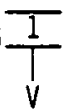

2

89

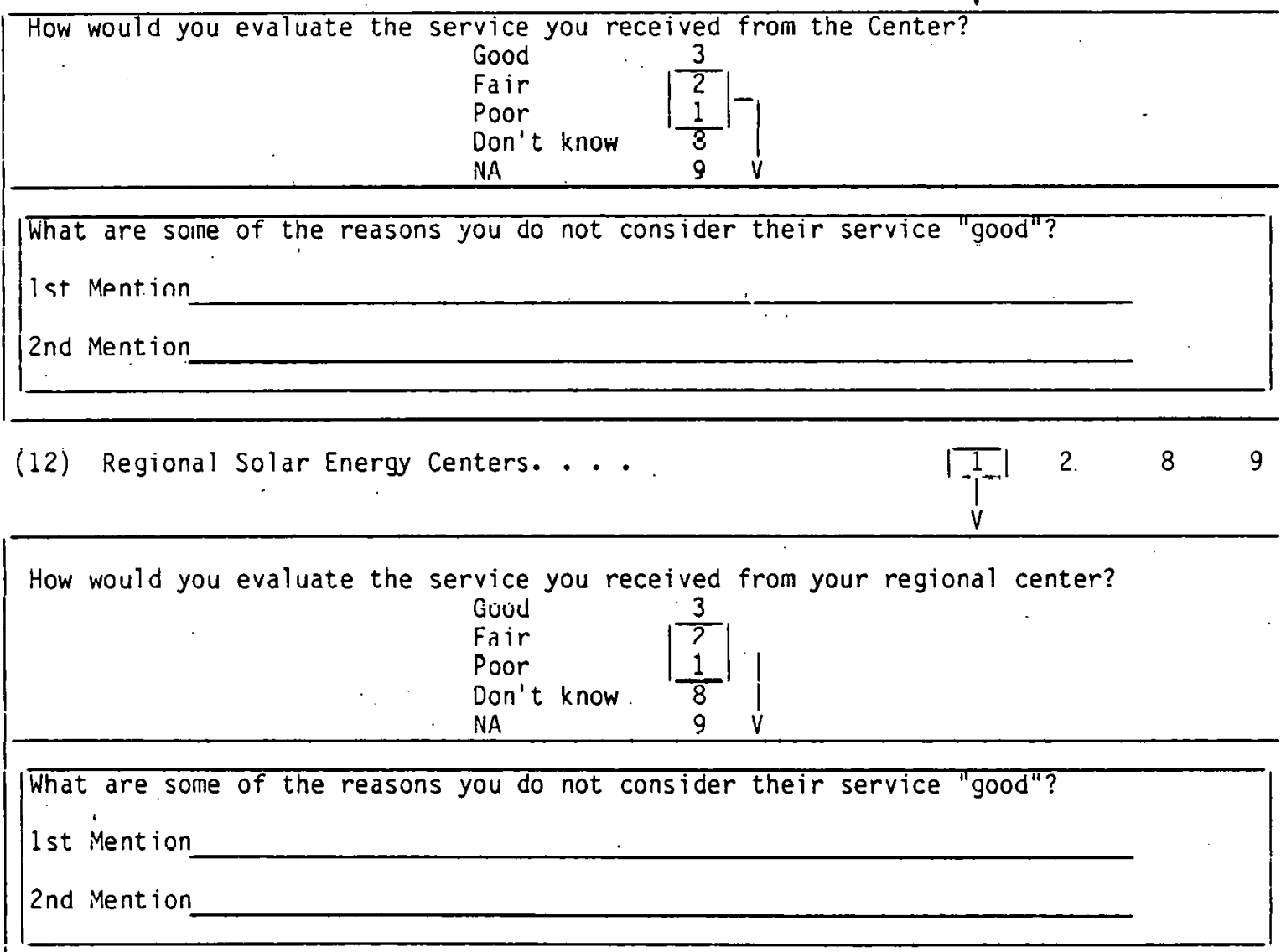


$\operatorname{cd} 4$

(Cont'd)

(13) Directly from the U. S. Department of Energy. .

Yes No Know

NA

(14) Radio or TV. . .

$\begin{array}{llllll}1 & 2 & 8 & 9 & 34\end{array}$

(15) Periodicals, newspapers or magazines

$\begin{array}{lllll}1 & 2 & 8 & 9 & 35\end{array}$

(16) Private solar energy or environiental organizations...

(16) Private solar energy or environmental organizations . .

(17) State Energy or Solar Offices...

(18) Some other state or local government office or publication.l $\quad 2 \quad \begin{array}{llll}8 & 9 & 39\end{array}$

(19) The local chapter or national headquarters of the International Solar Energy Societ.y (ISES), including tineir publications. . . .

(20) The local chapter or national headquarters of the Solar Energy Industries Association (SEIA), including their publications....

(21) The local or national office of the U.S. Departinent of Agriculture, including Extension and Forestry. . . . $1142 \quad 8 \quad 942$

(22) Bio-Energy Council $11.2 \quad 8 \quad 943$

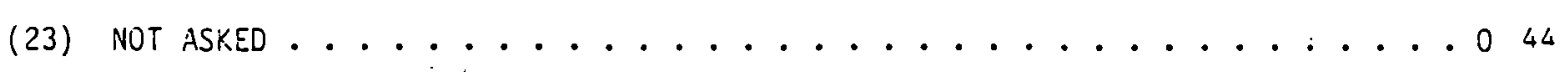

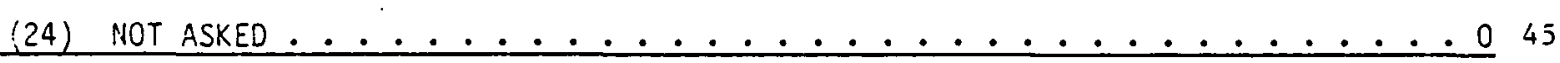

$46-47$ B $1 \mathrm{k}$

Figure D-1. Questlonnalre (continued) 
In conclusion, I would like to ask you some questions about yourself. Your answers will be kept completely confidential.

Dla. What is the highest level of education you have completed? (DO NOT READ) 8th grade or less........ 01

Some high school ....... 02

H lyh schiuul yrdduale...... . . 03

Post high school vocational/

Technical. ........ 04

Attended college/University:

No degree. ......... 05

Associate (2 year junior/ Comiuntey collogo) : : , : : П :

CRarhelors. . . . . . . . 07

-Maslers. . . . . . . . . 00

Ehrofoctorate : : : ....00

JJO/LLD ............ 10

-other

(SPECIFY)

Don't know......... 98

NA.............. 99

01b. In what field is your most recent degree?

0lc. In what year did you get that degree?

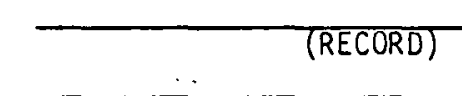

(YEAR) Verb.

02a: Please describe your present profession by completing the following statement: "Based on my total education and experience, I now regard myself professionally as a. (an) " " (AVOID USING JOB TITLE IF POSS I BLE).

D2b. How many years have you been in this profession? (CIRCLE CODE)

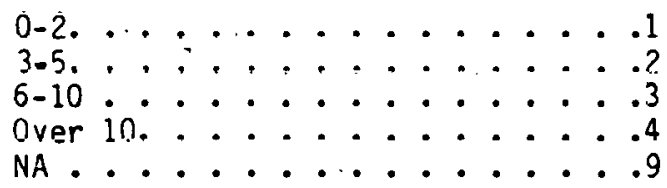

Figure D-1. Questionnaire (continued) 
Cd 4

D3. Do you belong to any professional, tech- Y Yes. . . . . . . . . . . . . I nical, or other organizations which have Yes (BUT CAN'T NAME) . . . . . . . 2 an interest in solar?

No . . . . . . . . . . . . . 3

Don't know . . . . . . . . 8

NA ................9

a. What organizations?

1st Mention

2nd Mention

3rd Mention

4th Mention

54-69 B1k

Thank you very much for your time.

Figure D-1. Questionnaire (concluded) 
Cd 1

B1-16. Please describe the type of biomass energy system your organization has. [IF ORGANIZATION HAS MORE THAN ONE SYSTEM WITH WHICH RESPONDENT IS FAMILIAR, PLEASE DESCRIBE EACH SEPARATELY. ASK. AS OPEN END.]

$37 \mathrm{C}+\mathrm{V}$ *

B2-12a. Was this biomass energy system installed while you were manager or was the system installed by a previous manager? (It MURE IHAN UNE ABUVE, ANSWER B'-B3 FUR 'ONE WITH WHICH RESPONDENT .IS MOST FAMILIAR.)

Original manager. ........ 2

Previous manager installed system . 3

Don't know. . (TERMINATE) ... 8

NA. ..... (TERMINATE) ... 9

B3-13. How many years have you been manager

3 months or less. . . . . . 1 of this.biomass conversion system?

Between 3 months and 1 year....2

$1-3$ years........ 33 *...

Over 3 years........ 4

Don't know. ....... 8

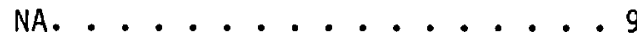

Figure D-2. User Questionaire 
Cd 1

B4-5. Knowing what you now know in terms of obtaining information about biomass energy systems, please answer the following questions as if you were starting over again and first considering the installation of a biomass energy system.

What would be the most important information product or service about biomass 33-34 Blk energy that you would want to have? (PROBE FOR TWO MENTIONS)

lst Mention

2nd Mention

$35 \mathrm{C}+\mathrm{V}$

B5-14. What is the first thing you would do to obtain information about biomass energy?

That is, where would you go, or who would you contact to get the information you needed? (PROBE FOR TWO MENTIONS)

lst Mention

2nd Mention

Figure D-2. User Questionaire (continued) 
Cd 1

8a. I will read a list of potential information products on biomass energy systems.

For each, please tell me how useful that information would be to you. Would

the following be: essential, very useful, somewhat useful, or not at all useful? [READ LIST. ROTATE. CIRCLE. ONE RESPONSE PER ITEM]

\begin{tabular}{|c|c|c|c|c|}
\hline [ssential & $\begin{array}{c}\text { Very } \\
\text { Usefiul }\end{array}$ & $\begin{array}{c}\text { Somewhat } \\
\text { Use }\lceil u ?\end{array}$ & $\begin{array}{l}\text { At All } \\
\text { Useful }\end{array}$ & $\begin{array}{l}\text { Don't } \\
\text { Knuw }\end{array}$ \\
\hline
\end{tabular}

(1) A bibliography of general readings

on biomass energy systems. .... 4

2

1

$8 \quad 9 \quad 43$

(2) A list of sources for information on particular biomass energy systcms. A

(3) A calendar of upcoming biomass energy conferences and prograins. . 4

(4) Diagrains or schematics of a specific

biomass processing system. . . . 4

3

4

3

2

1

$8 \quad 9 \quad 11$

(5) A non-technical description of how a particular biomass energy system works. . .

(6) A technical description of how a particular biomass energy system works. . .

1

84

(7) Lists of local lenders, insurers, builders, engineers, installers or distributors for biomass energy systellis ....

1

89

46

(8) Biomass erergy system design handbooks, installation handbooks or reference tables. . .

(9) A list of technical experts in a specific area of biomass energy. . . 4

(10) Manual methods for sizing and predicting the engineering performance or life cycle costs of biomass energy systens.....

(11) Computer models for sizing and predicting the engineering performance or life cycle costs. . . 


\section{Cd 1}

87-8b. I will next read a list of types of information on biomass energy systerns. For each, please tell me how. useful information of that type would be to you. Would the following be: essential, very useful,.. somewhat useful or not at all useful? [READ LIST. ROTATE. CIRCLE ONE RESPONSE PER ITEM]

Not

$\begin{gathered}\text { Very } \\ \text { Essential Useful }\end{gathered}$ Usewhat At All Don't
Useful Useful Know NA

(1) Educational institutions and other organizations offering courses on biomass energy....

(2) Biomass energy system research currently. in progress. . .

(3) The state-of-the-art in biomass energy systems....

\section{4}

4

4

(4) Costs and performance of biomass energy installations. ....

(5) Costs of installing and operating a biomass energy system compared to a conventional system. ...

4

(6) Local building codes or other regulations affecting siting or installation of biomass energy systems . . . 4

(7) Tax credits, grants, or other economic incentives for biomass energy applications...

(3) Standards, specifications, or certification programs for biomass energy equipment and installations. . . t

(9) Marketing statistics and sales projections for biomass production, collection or conversionn equipment. $4 . \quad 3 \quad 2 \quad 1 \quad 33$

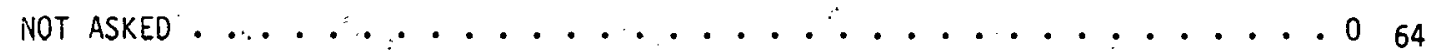
NOT ASKED . . . . . . . . . . . . . . . . . . . . . . 065

(12) Institutional, social, environmental, and legal aspects of biomass energy applications. . . 4

(13) Expected major developments in biomass energy, applications during the next ten years. . .

(14) Climatological jata such as wind, weather, alnount of sunshine, rainfall, or data on soils. . 4

4

$\begin{array}{llllllll}4 & 3 & 2 & 1 & 8 & 9 & 68\end{array}$


Cd 4

$1-10$ as 1

88-9. When your current biomass system was being considered for purchase, was there information on biomass energy which you needed but were not able to get?

Yes . . . . . . . . . . . 1

Yes (BUT CAN'T DESCRIBE). . . . . 2

No. .......... 3

Don't know. .......... 811

NA. ............ 9

(IF YES) What biomass energy information couldn't you get?

lst mention

2nd ment ion

$12-16 \mathrm{Blk}$

Figure D-2. User Questionaire (continued) 
$\operatorname{cd} 4$

B9-11. Solar information refers to information about any solar technology, and factors which may relate to its use such as weather, economics, legislation, architecture, environment, etc. In the past few years, have you obtained any type of solar information from any of the following sources? [READ LIST. CIRCLE ONE RESPONSE PER ITEM.]

(1) Your organizational library or a local library. .

(2) A public utility company. . No Know NA

(2) A public utility company. $\cdot$.

$\begin{array}{lllll}1 & 2 & 8 & 9 & 17 \\ 1 & 2 & 8 & 9 & 18\end{array}$

(3) An installer, builder, designer or manufacturer of solar systems.........

$\begin{array}{lllll}1 & 2 & 8 & 9 & 19\end{array}$

(4) Workshops, conferences or training sessions. . $\begin{array}{lllll}1 & 2 & 8 & 9 & 20\end{array}$

(5) A commercial data base, for example, Lockheed, ȘDC, BRS. - $1 \quad 2 \quad 21$

(6) A Federal library or information center, for example, the National Agricultural Library or the Environmental Data System. .

(7) Smithsonian Science Information Exchange (SSIE) . * . $\quad \begin{array}{llllll}2 & 8 & 9 & 23\end{array}$

(8) The Governinent Printing office (GPO) . . .

How would you evaluate the service you received from GPO?

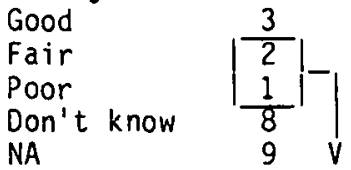

NA

What are some of the reasons you do not consider their service "good"?

lst Mention

2nd Mention

(9) National Technical Information Service (NTIS). .... $\left|\frac{1}{V}\right|_{V} 28$ 26

\begin{tabular}{|l} 
How would you evaluate the service you received froin NTIS? \\
Good \\
Fair \\
Poor \\
Don't know \\
NA
\end{tabular} \mid


B9-11. (Cont'd)

(Cont'd)

(10) Technical Information
Cd 4
$\begin{array}{cccc}. \cdot & \text { Cd } 4 \\ & \text { Don't }\end{array}$
Yes No know NA
$\begin{array}{llllll}1 & 2 & 8 & 9 & 28\end{array}$

How would' you evaluate the service you received from TIC?

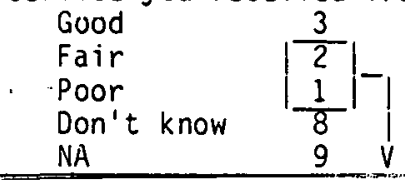

What are some of the reasons you do not consider their service "good"?

let Mention

2nd Mention

(11) National Solar Heating and Cooling Information Center. $\therefore|\bar{V}| \frac{1}{V} 29$

How would you evaluate the service you received from the Center?

\begin{tabular}{l|l} 
Good & $\frac{3}{2}$ \\
Fair \\
Poor \\
Don't know $\left|\frac{1}{8}\right|-$ \\
NA
\end{tabular}

What are some of the reasons you do not consider their service "good"?

lst Mention

2nd Mention

(12) Regional Solar Energy Centers. . .

How would you evaluate the service you received from your regional center?

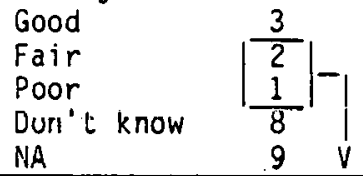

What are some of the reasons you do not consider their service "good"?

lst Mention

2nd Mention

Figure D-2. User Questionaire (continued) 
B9-11. (Cont'd)

(13) Directly from the U. S. Department of Energy. .

(14) Radio or TV.......

(15) Periodicals, newspapers or magazines. .....

(16) Private solar energy or environmental organizations ... I

(17) State Energy or Solar Offices...

(18) Some other state or local governinent office or publication.l

(19) The local chapter or national headquarters of the International Solar Energy Society (ISES), including their publicat-

ions....

(20) The local chapter or national headquarters of the Solar Energy Industries Association (SEIA), including their publications. . .

(21) The local or national office of the U.S. Departinent of Agriculture, including Extension and Forestry. ...

(22) Bio-Energy Council

(23) The Wood Energy Institute.......

(24) NOT ASKED

B10-7. What publications have you read in the past six months that include information on biomass energy systems? cd 4

Don't

Yes Nn Knnw NA

$\begin{array}{lllll}1 & 2 & 8 & 9 & 34\end{array}$

$\begin{array}{llllll}1 & 2 & 8 & 9 & 35\end{array}$

$\begin{array}{lllll}1 & 2 & 8 & 9 & 36\end{array}$

$\begin{array}{llll}2 & 8 & 9 & 37\end{array}$

$2 \quad 8 \quad 9 \quad 38$

$\begin{array}{llll}2 & 8 & 9 & 39\end{array}$

$\begin{array}{lllll}1 & 2 & 8 & 9 & 40\end{array}$

$\begin{array}{llllll}1 & 2 & 8 & 9 & 41\end{array}$

$\begin{array}{lllll}1 & 2 & 8 & 9 & 42\end{array}$

1. $2 \quad 2 \quad 8 \quad 96 \quad 43$

$\begin{array}{lllll}1 & 2 & 8 & 9 & 44\end{array}$

............... ${ }^{46-4 T^{1} \mathrm{~B}_{\mathrm{K}}^{0}}$

None ............ . 001 cd 2

Read, but can't remember titles. . . 002 (VOLUNTEERED)

$11-75$ Blk

$76 \mathrm{Cd}$ \#

Read too many to name. ..... 003 77-80 (VOLUNTEERED)

(ASK) Which are most important? (RECORD TITLES)

Job \#

Cd 3

$1-10$ as

Names Publications ....... 004 11-43 B1 (RECORD TITLES)

1 st mention

$44 C+V$

2nd mention

$\mathrm{CL}$ 45-51 Blk

3rd mention 
Cd 4

In conclusion, I would like to ask you some questions about yourself. Your. answers will be kept completely confidential.

Dla. What is the highest level of education you have completed? (DO NOT READ) 8th grade or less........ 01

Sorne high school ....... 02

High school graduate...... 03

Post high school vocational/

Technical. .......0.04

Attended college/University:

No degree. . . . . . . 05

Associate (2 year junior/

Comunity college). . . . 06

Bachelors. . . . . . . . 07

TMatlulb. . . . . ..... 08

Fh.D/Doctorate........ 09

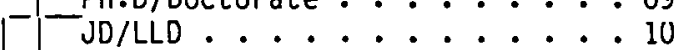

\section{8}

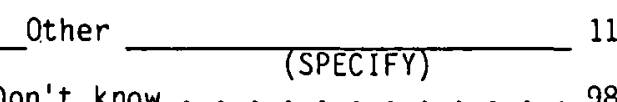

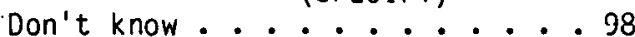

NA............. 99

Dlb. In what field is your most recent degree?

D1c. In what year did you get that degree?

(RECORD)

11-1. In the next year do you expect to need additional biomass energy information...

(a) On your job? Yes...... 1

No ...... 2

Don't know... 8

$\mathrm{Na} \cdot . . . .9$

(b) Outside of your

job?, Yes....... 1

No ...... 2

Don't know...8

NA...... 9

D2a. Please describe your present profession by completing the following statenent: "Based on my total education and experience, I now regard nyself professionally ก) $n(a n)$ ." (AVOID USING JOB TITLE IF POSSIBLE). 

D3. Do you belong to any professional, tech- Fres.................
nical, or other organizations which have Yes (BUT CAN'T NAME) . . . . . . . 2 an interest in solar?
No ............... 3
Don't know............ 53

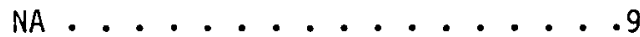

a. What organizations?

1st Mention

2nd Mention

3rd Mention

4th Mention

54-69. BIK

Thank you very much for your time.

Figure D-2. User Questionaire (concluded) 
Therefore, this report refers to the responses to Question 5 as "information which was important for the respondents to obtain."

Question 6. In this question, a list of different biomass energy applications was read to the respondent and the respondent was asked which application he was particularly interested in obtaining information for. After this was completed, respondents were asked, "Are there any other areas of biomass energy for which you are particularly interested in obtaining information?" Responses to this question fell into one of two areas: additional biomass applications of interest or specific types of information wanted. The former were discussed with other results from Question 6; the latter were included with the responses from Question 5.

Question 8. In this question a list of up to 25 specific information products or types of information was read to the respondent. The respondent rated each item as "essential," "very useful," "somewhat useful," or "not at all useful" as it applied to himself. In contrast to Question 5, this question assessed each respondent's ratings for each of a set of items that the study designers thought might be important to the respondents. Question 8 did not allow respondents to add and rate items not already on the list. To reduce the possibility of introducing bias due to item order within Question 8, the interviewers rotated their starting point by randomly selecting which item would be read to the respondent first. Items in Question $8 \mathrm{a}$ were rotated separately from those in Question $8 \mathrm{~b}$.

Question 9. This question asked, "Is there any biomass energy information which you need but are not able to get?" Unfortunately, this question just did not work. Answering Questions $8 \mathrm{a}$ and $8 \mathrm{~b}$ required the respondent to assign a rating to each of $22-25$ information items. By the time the respondents had completed Question 8 they were usually starting to get fatigued with the interview. As a result many did not answer Question 9 at all.

Question 11. In this question respondents were not asked if they had obtained solar information from Solar Energy Research Institute (SERI). The principal reason was the probability of obtaining biased responses. All respondents had received a letter describing the Solar Energy Information Data Base (SEIDB) and introducing SERI. It was felt that many respondents would attempt to encourage information flows from SERI by responding positively when asked whether they had used SERI as an information sourcewhether or not they actually received information directly from SERI. Since explaining the nature of SEKI and the SEIUB was necessary to promote a good response rate, no questions about SERI were included.

In Question 11, items 21-23 require some explanation: they are shown as "NOT ASKED" on the sample questionnaire (readers may note that data for items 21-23 does occur on the tables in Appendix $F$ for some groups). These items were left open for the inclusion of specific organizations which seemed most appropriate for each group. Table D-1 lists the organizations, the respondent groups and the question numbers for each item used for the groups covered in this report. 


\section{Table D-1. SELECTED ORGANZATIONS ABOUT WHICH BIOMASS RESPONDENTS WERE ASKED}

\begin{tabular}{lcl}
\hline \multicolumn{1}{c}{ Group } & Item $^{\text {a }}$ & \multicolumn{1}{c}{ Organization } \\
\hline All Biomass Groups & 21 & $\begin{array}{l}\text { U.S. Department of Agriculture, } \\
\text { including Extension and Forestry } \\
\text { Bio-Energy Council }\end{array}$ \\
$\begin{array}{l}\text { All Biomass Groups } \\
\begin{array}{l}\text { Biomass State Forestry Office Repre- } \\
\text { sentatives }\end{array}\end{array}$ & 22 & Wood Energy Institute (WEI) \\
$\begin{array}{l}\text { Biomass Forest Products Engineers/ } \\
\text { Consultants }\end{array}$ & 23 & WEI \\
$\begin{array}{l}\text { Biomass Cooperative Extension } \\
\text { Service County Agents }\end{array}$ & 23 & WEI \\
Biomass System Managers & 23 & WEI \\
Biomass Private Foresters & 23 & State Department of Agriculture \\
\hline
\end{tabular}

${ }^{2}$ The number of the item in which the group was asked about the particular organization. For example, 21 is Item 21 of Question 11.

\section{User Questionnaire}

B1-16. Users were asked to describe their present system, rather than areas of interest; the question was open-ended and no list of system types was provided as in Question 6 of the standard questionnaire.

B2-12a, B3-13. Asked only of users.

B4-5 and B5-14. These questions differ from the standard Question 5 in that the user respondent is asked about information and information sources that would be sought out if the system were currently being considered for purchasc or construction.

B8-9. The standard Question 9 is altered by referring to "when your current system was being considered."

B11-1. The standard Question 1 is altered by asking about "additional" biomass energy information. 
SERI 
APPENDIX E

STATISTICAL TESTING 


\section{S=P1}


Despite the small sample sizes, selected statistical tests could be used. All of these tests used a 5\% rejection region unless otherwise noted. Thus, if a test result indicated that a difference between two means was statistically significant $(P<0.05)$, it meant that there was only a one-out-of-twenty chance that the two means were not different. Actual calculations were made with the Statistical Package for the Social Sciences (SPSS) software and other computer packages.

The tests conducted fell into three main types: tests of proportions between two groups, $\mathrm{t}$-Tests between two groups, and Paired $\mathrm{t}$-Tests within a group. Each of these are discussed below.

For all except Question 8, tests of proportions were used. For example, the proportion of Biomass Private Foresters using computer terminals was compared to the proportion of Biomass State Forestry Representatives using computer terminals. If the sample sizes were small, Exact Binomial Tests were used. When the sample sizes were larger (e.g., a comparison of Biomass Federally Funded Production and Collection Researchers to All Researchers), Chi-Square Tests were used.

For analysis of the results from Question 8, t-Tests were used. In Question 8 each respondent was asked to describe the usefulness of up to 25 information products/ categories as either "essential," "very useful," "somewhat useful," or "not at all useful." The "average usefulness" rating that the group assigned an item was then calculated by assigning the responses a "4" for "essential," a "3" for "very useful," a "2" for "somewhat useful," and a "l" for "not very useful," then calculating the average for the entire group. A t-Test was used to determine whether group A rated a specific information item significantly higher (or lower) than it was rated by group B. Some groups, however, tended to give higher scores in general than did other groups. To compensate for this effect, these statistical tests compared the "relative rating" given by one group to the "relative rating" given by the other groups. The relative rating given by a group to a particular item was calculated as follows: take the average usefulness rating the group gave that item (for example, suppose "a bibliography" received a 3.15 rating), then subtract the average overall rating this group gave to all items (suppose the average rating the group gave all items was 2.75); the difference was the relative rating (for this example $3.15-2.75=+0.40$ ). The $t$-Test then was used for the comparison of the relative rating group $A$ gave to the item with the relative rating group $B$ gave the item. For the tests of proportions (or the t-Tests involving Question 8), if group A was being compared to group B and group A was a subset of group B (e.g., a comparison of Federally Funded Biomass Production and Collection Researchers to All Researchers), the totals for group A were subtracted from the totals for group B and the proportions (or the relative ratings) for group B were recalculated from the adjusted totals.

For Question 8 it sometimes occurred that the researcher wanted to compare the rating a group gave one item to the rating they gave another item. For example, did Representatives of Biomass Production and Collection Equipment Manufacturers rate "lists of sources for information" significantly higher (or lower) than they rated "lists of technical experts?" This test was conducted using a Paired t-Test. 


\section{SE리}


APPENDIX $\mathrm{F}$

BIOMASS DATA TABLES 


\section{SFPl新}


In the following biomass data tables, each table entry shows counts and percentages displayed in the format ( $\%^{\#)}$; where $\%$ is the column percentage for each group and \# is the number of respondents in each group who gave the response shown in the row title. Each column shows the results for an individual group or for a combination of groups.

Table F-1 lists the groups and combinations for which data are shown in the data tables. Table F-2 shows which groups are included in each of the combination groups listed in Table F-1. Table F-3 lists the data tables and Fig. F-1 contains the data tables themselves.

Table F-1. GROUPS AND COMBINATION GROUPS WTH DATA INCLUDED IN APPENDIX F.

Biomass Federally Funded Production and Collection Researchers (BIOM FED P\&C RES)

Biomass Federally Funded Conversion Researchers (BIOM FED CONV RES)

3.0

Biomass Nonfederally Funded Production and Collection Researchers

3.0

(BIOM NFED P\&C RES)

Biomass Nonfederally Funded Conversion Researchers (BIOM NFED CONV RES)

Total Biomass Federally Funded Researchers (TOTAL BIOM FED RES)

3.0

Total Biomass Nonfederally Funded Researchers (TOTAL BIOM NFED RES)

3.0

Total Biomass Production and Collection Researchers (TOTAL BIOM P\&C RES)

3.0

Total Biomass Conversion Researchers (TOTAL BIOM CONV RES)

3.0

Total Biomass Researchers (TOTAL BIOM RES)

3.0

All Researchers (ALL RES)

3.0

3.0

Biomass Production and Collection Equipment Manufacturer

Representatives (BIOM P\&C EQUIP MANUF)

Biomass Conversion Equipment Manufacturer Representatives (BIOM CONV EQUIP MANUF)

Total Biomass Manufacturer Representatives (TOTAL BIOM MANUF)

Biomass State Forestry Office Representatives (BIOM STATE FORST OFF)

Biomass Private Foresters (BIOM PRIV FRSTR)

Biomass Forest Products Engineers/Consultants (BIOM FORST PROD ENG)

All Educators (ALL EDUC)

All Cooperative Extension Service County Agents (ALL CES CO AGENT) 
Table F-2. COMBINATION GROUPS

Total Biomass Federally Funded Researchers (TOTAL BIOM FED RES)

Biomass Federally Funded Production and Collection Researchers

Biomass Federally Funded Conversion Researchers

Total Biomass Nonfederally Funded Researchers (TOTAL BIOM NFED RES)

Blomass Nonfederally Funded Production and Collection Researchers

Biomass Nonfederally Funded Conversion Researchers

Total Biomass Production and Collection Researchers (TOTAL BIOM P\&C RES)

Biomass Federally Funded Production and Collection Researchers

Biomass Nonfederally Funded Production and Collection Researchers

Total Biomass Conversion Researchers (TOTAL BIOM CONV RES)

Biomass Federally Funded Conversion Researchers

Biomass Nonfederally Funded Conversion Researchers

Total Biomass Researchers (TOTAL BIOM RES)

Biomass Federally Funded Production and Collection Researchers

Biomass Federally Funded Conversion Researchers

Biomass Nonfederally Funded Production and Collection Researchers

Biomass Nonfederally Funded Conversion Researchers

All Researchers (ALL RES)

Photovoltaics DOE-Funded Researchers

Photovoltaics Non-DOE-Funded Researchers

Photovoltaics Researcher Manufacturers

Biomass Federally Funded Production and Collection Researchers

Biomass Federally Funded Conversion Researchers

Biomass Nonfederally Funded Production and Collection Researchers

Biomass Nonfederally Funded Conversion Researchers

Wind DOE-Funded Researchers

Wind Non-DOE-Funded Researchers

Solar Thermal Electric Power (STEP) DOE-Funded Researchers

STEP Non-DOE-Funded Researchers

Ocean Energy DOE-Funded Researchers

Ocean Energy Non-DOE-Funded Researchers

Solar Energy Storage DOE-Funded Resear chers

Solar Energy Storage Non-DOE-Funded Researchers

Active Solar Heating and Cooling (SHAC) DOE-Funded Researchers

SHAC Non-DOE-Funded Researchers

Passive Federally Funded Researchers

Industrial Process Heat (IPH) Researchers

Agricultural Process Heat (APH) Researchers

Total Biomass Manufacturer Representatives (TOTAL BIOM MANUF)

Biomass Production and Collection Equipment Manufacturer Representatives

Biomass Conversion Equipment Manufacturer Representatives 
Table F-2. COMBINATION GROUPS (Concluded)

All Manufacturer Representatives (ALL MANUF)

Photovoltaics Manufacturer Representatives

Biomass Production and Collection Equipment Manufacturer Representatives

Biomass Conversion Equipment Manufacturer Representatives

Wind Manufacturer Representatives

STEP and IPH Concentrating Collector Manufacturer Representatives

SHAC Heating/Cooling System Manufacturer Representatives

SHAC Water Heating System Manufacturer Representatives

SHAC Nonconcentrating Collector Manufacturer Representatives

SHAC Other Component Manufacturer Representatives

Passive Manufacturer Representatives

All Engineers (ALL ENG)

Photovoltaics Electric Power Engineers

Biomass Forest Products Engineers and Consultants

Wind Engineers

Wind Electric Power Engineers

STEP Engineers

SHAC Heating, Ventilating and Air Conditioning Engineers

SHAC Industrial Engineers

IPH Plant Engineers

IPH Industrial Engineers

IPH Private Agricultural Engineers

State Level Cooperative Extension Service (CES) Agricultural Specialists

(Agricultural Engineers)

All Educators (ALL EDUC)

Photovoltaics Educators

Biomass Educators

Wind Educators

STEP Educators

SHAC Educators

Passive Educators

IPH Educators

All Cooperative Extension Service County Agents (ALL CES CO AGENT)

Biomass CES County Agents

Wind CES County Agents

SHAC CES County Agents

Passive CES County Agents

APH CES County Agents

All Cooperative Extension Service State Specialists (ALL CES STATE SPEC)

State Level CES Agricultural Specialists

State Level CES Information Speciallsts 
Table F-3. IIST OF BIOMASS DATA TABLES

Question

Number ${ }^{\mathbf{a}}$

Table Title

Page

User and Nonuser Questionnaires

Question $1 \quad$ Need for Information On the Job and Outside the Job ......... 199

Question $2 \quad$ Involvement ................................... 201

Question $3 \quad$ Informedness ................................... 203

Question $6 \quad$ Interest in Specified Biomass Energy Areas . . . . . . . . . . . 205

Question 8A Usefulness of Specified Information Items ................ 207

Question 8B Usefulness of Specified Information Items . . . . . . . . . . . . 219

Question 10 U̇se of Special Acquisition Methods . ..................... 233

Question 11 UsC of Sclcetcd Solar Information Sourcos ... . . . . . . . . . . 235

Question D2B Years in Current Profession .......................... 249

Question D3 Membership in Solar-Interested Organizations.............. 251

User Questionnaire Only

Question B2-13/B3-13 Number of Years ........................... 253

Question B2-12/B2-12A Owner/Manager ............................ 254

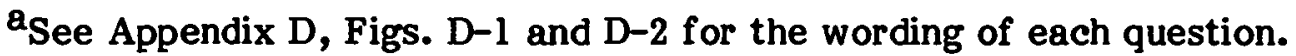


(OCTOBER. 1979$)$

NEED FOR INFORMATION ON THE JOB AND OUTSIDE: THE JOB (QUESTION 1 )

BIOMASS ENERGY

YES FOR JOB

NO FOR JOB

DON T KNOW/NA

Q1.B TOTAL.

YES OUTSIDE JOB

NO OUTSIDE JOB

DON'T KNOW/NA

YES. JOB + OUTSIDE
BIOM BIOM BIOM BIOA. TOTAL TOJAL TOTAL TOIAL TOTAL AL

FED FED NFED MFED BIOM BIOM BIOM BIOA RIDM RES

$100^{\circ} 100^{10} \cdot 100^{9} \cdot 100^{9} \cdot 100^{8} \cdot 100^{8} \cdot 10 f^{7} \cdot 100^{19} \cdot 100^{6} \cdot 10^{8} 1$

P+C CONV TOTAL MALUT EQUIP EOUIP

$10091009100^{8}, 100^{96}$

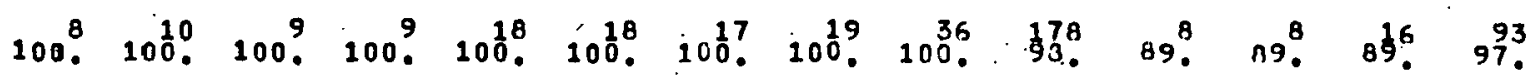

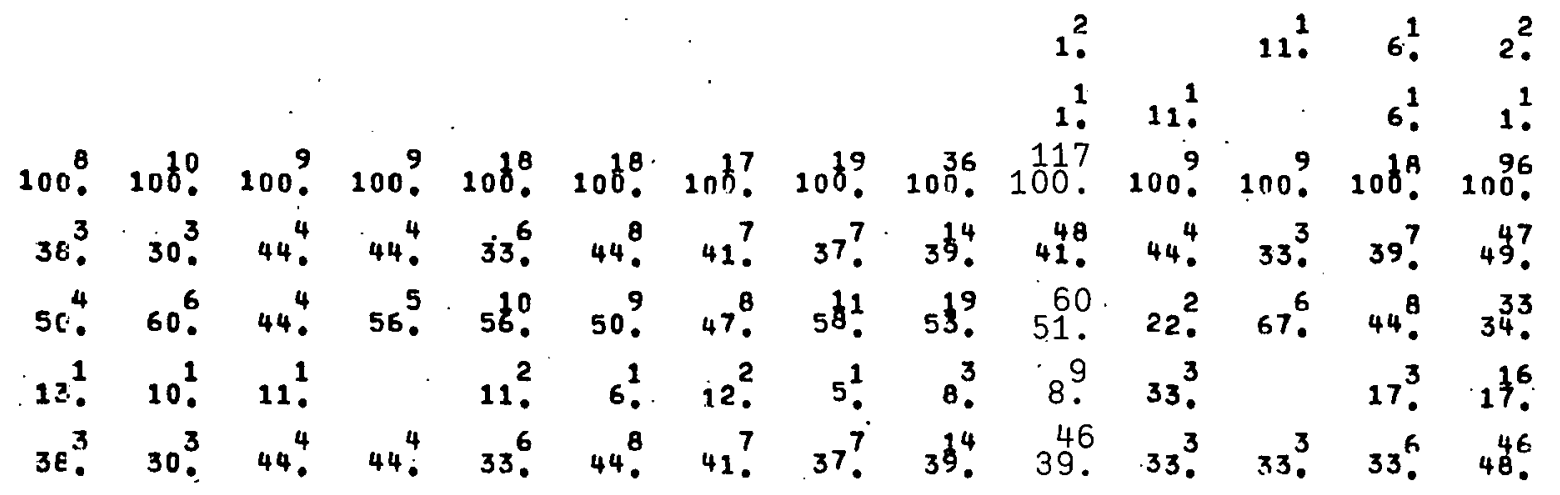

Figure F-1. Biomass Data Tables 


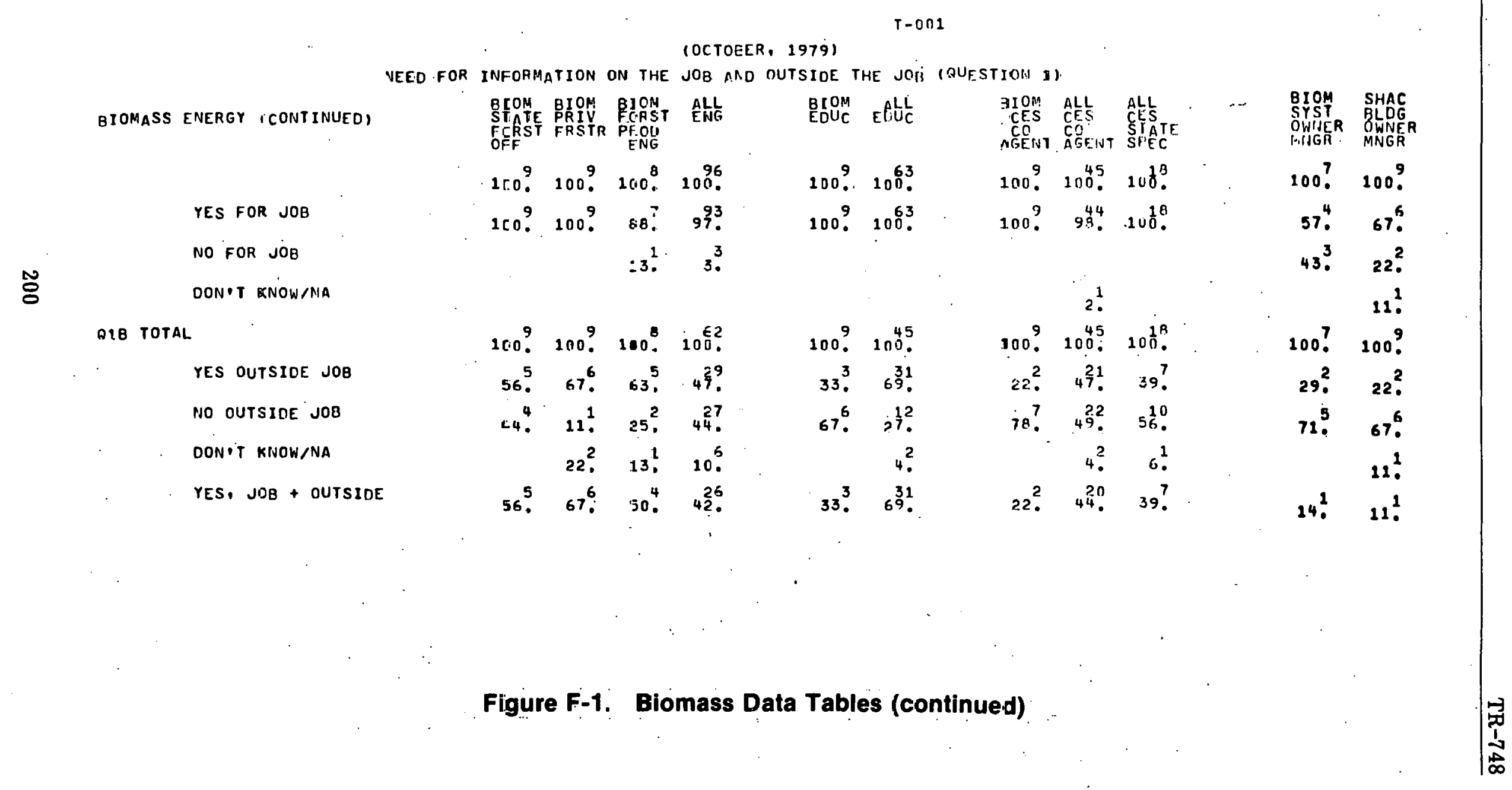




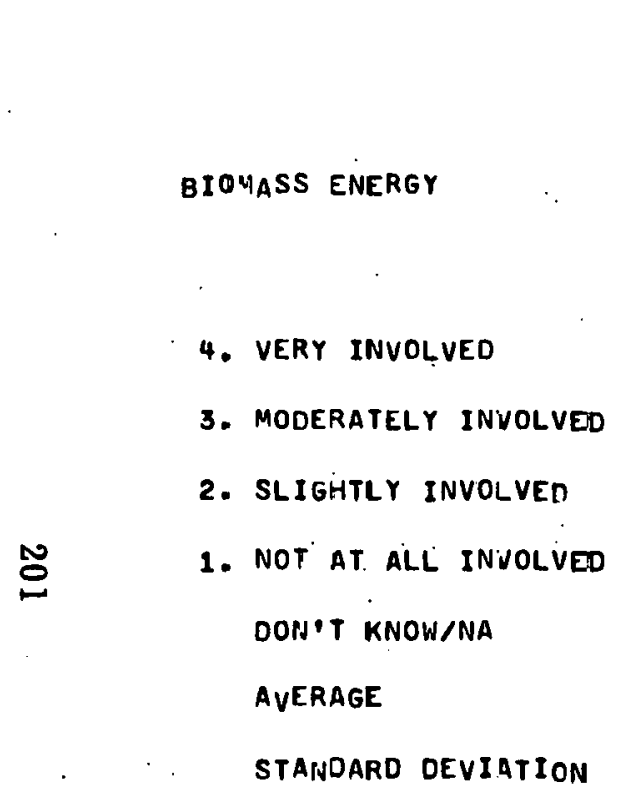

\begin{tabular}{|c|c|c|c|c|c|c|c|c|c|c|c|c|c|}
\hline & & NVOLVE & $\begin{array}{r}\text { COCTO } \\
\text { MENT } 1\end{array}$ & $\begin{array}{l}\text { BER, } 1 \\
\text { QUESTI }\end{array}$ & $\begin{array}{l}9791 \\
\text { ON 21 }\end{array}$ & $T-0$ & & & & & & & \\
\hline $\begin{array}{l}\text { BIOM } \\
\text { FED } \\
P_{+} \\
\text {RES }\end{array}$ & $\begin{array}{l}\text { BIOM } \\
\text { FED } \\
\text { CONV } \\
\text { RES }\end{array}$ & $\begin{array}{l}\text { BIOM } \\
\text { NFED } \\
\text { PEC } \\
\text { RES }\end{array}$ & $\begin{array}{l}\text { BIOM } \\
\text { NFED } \\
\text { CONV } \\
\text { RES }\end{array}$ & $\begin{array}{c}\text { TOIAL } \\
\text { BIOMM } \\
\text { REES } \\
\text { RES }\end{array}$ & $\begin{array}{l}\text { TOTAL } \\
\text { BJOM } \\
\text { NFEE } \\
\text { FEES }\end{array}$ & $\begin{array}{l}\text { TOTAL } \\
\text { RIOM } \\
\text { P+E } \\
\text { RFS }\end{array}$ & $\begin{array}{l}\text { TOIAL } \\
\text { BIOA } \\
\text { CONV } \\
\text { RES }\end{array}$ & $\begin{array}{l}\text { TOTAL } \\
\text { BIOM } \\
\text { RES }\end{array}$ & RELS & $\begin{array}{l}\text { BIOM } \\
\text { P+C } \\
\text { EUIP } \\
\text { MANUF }\end{array}$ & $\begin{array}{l}\text { BIOM } \\
\text { CONV } \\
\text { EOUIP } \\
\text { MANUF }\end{array}$ & $\begin{array}{l}\text { TOIAL } \\
\text { BIIMM } \\
\text { MANUF }\end{array}$ & MANLEF \\
\hline $100^{8}$ & $100^{10}$. & $1000^{9}$ & 1009 & $100^{8}$ & $100^{8}$. & $10 \delta^{7}$ & $10 t^{9}$ & 100 & $\begin{array}{l}1801 \\
100 .\end{array}$ & 100 . & 100 . & $108^{8}$. & $100^{96}$. \\
\hline $50^{4}$. & $60^{6}$. & $89^{\circ}$. & 56. & 53. & $7 \frac{1}{2}^{3}$. & $7 \frac{12}{1}$ & $5 \frac{1}{8}$. & $64^{23}$ & 597. & $78 !$ & $89^{8}$. & 835 & 87 \\
\hline $25^{2}$. & $30^{3}$ & & $33^{3}$. & $28^{5}$ & $17^{3}$ & $12^{2}$ & $32^{6}$ & $22^{8}$ & 2.43 & & & & 10 \\
\hline $25^{2}$ & $10^{1}$ & $11 !$ & 11 . & $17^{3}$ & $11^{2}$ & $18^{3}$ & $11^{2}$ & $14^{5}$ & $\begin{array}{c}29 \\
16 .\end{array}$ & $11^{1}$ & $11^{1}$ & $11^{2}$ & $7 !$ \\
\hline & & & & & & & & & 1 & $11^{1}$ & & $6 !$ & $1 !$ \\
\hline & & & & & & & & & 1. & & & & 1. \\
\hline 3.25 & 3.50 & 3.78 & 3.44 & 3.39 & 3.61 & 3.53 & 3.47 & 3.50 & 3.42 & 3.44 & 3.78 & 3.61 & 3.72 \\
\hline .82 & .67 & .61 & .70 & .75 & .68 & .77 & .69 & .72 & .78 & 1.08 & .61 & .89 & .61 \\
\hline
\end{tabular}

Figure F-1. Blomass Data Tables (continued) 


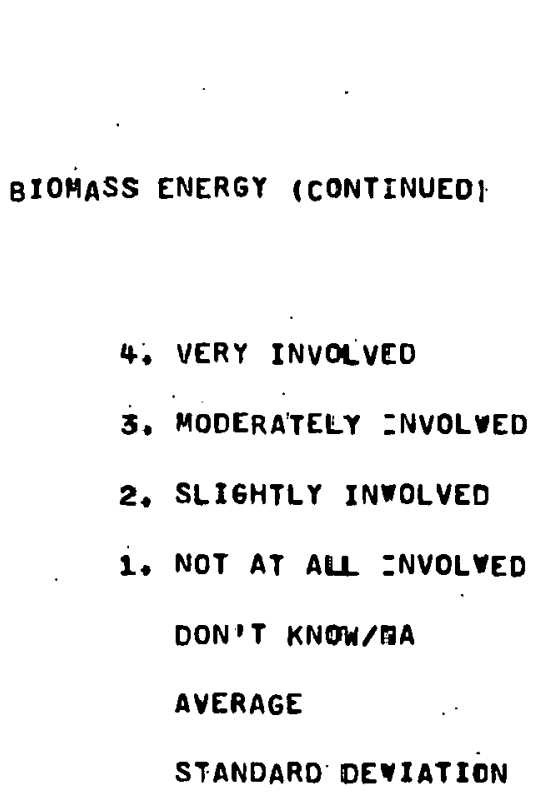

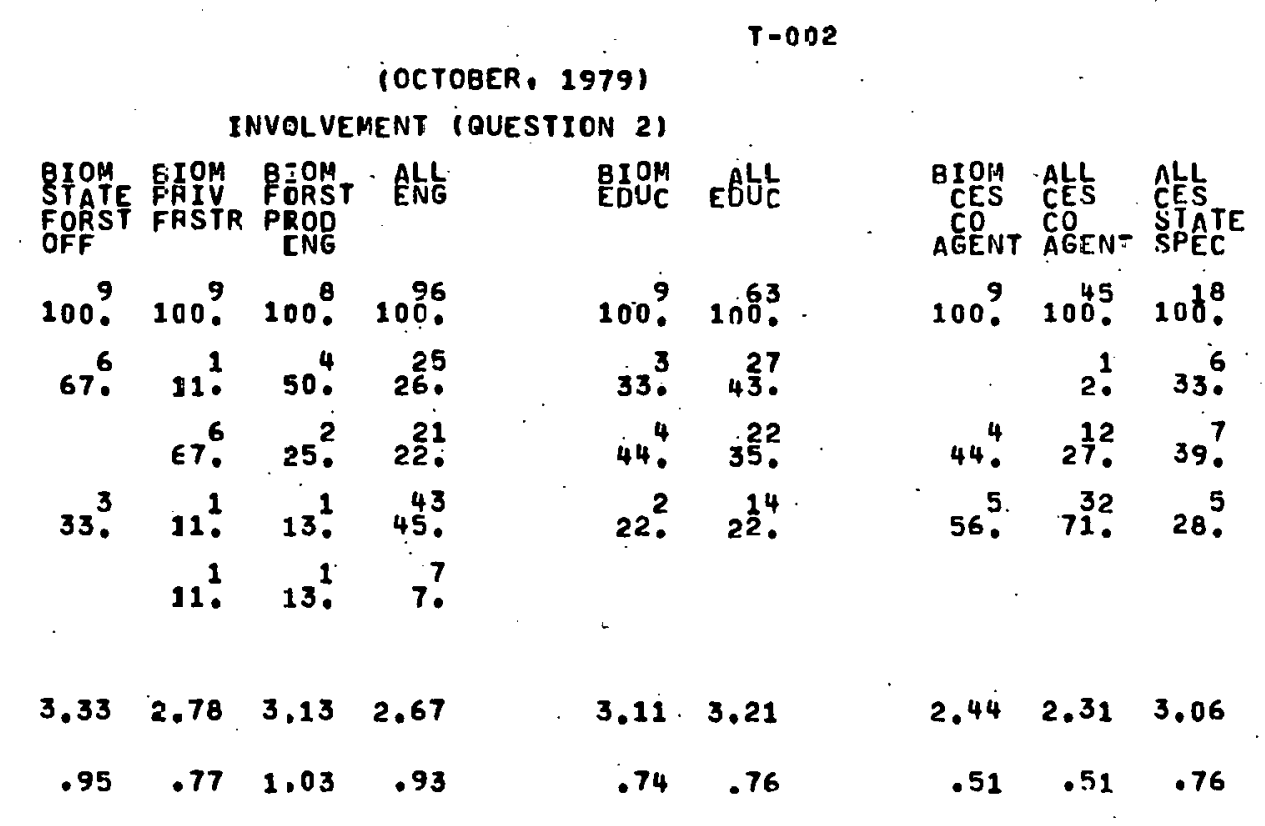

Figure F-1. Biomass Data Tables (continued) 
BIOMASS ENERGY

4. VERY INFORMED

3. MOOERATELY INFORMED

$\stackrel{\omega}{0}$

2. SLIGHTLY INFORMED

1. NOT AT ALL INFORMEO

DON T KNOW/NA

AVERAGE

STANDARD DEVIATION
(OCTOBER, 1979 )

- INFORMEDNESS (QUESTION 3)

BIOM BIOM BIOM BIOM TOTAL TOTAL TOTAL TOTAL TOTAL ALL BIOM BIOM TOTAL BAL
FED
PEE NFED

PEC CONV P+C CONV FED NFED P+C CONV RES RES ROUIP EQUIP

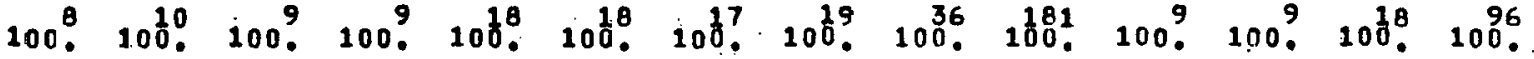

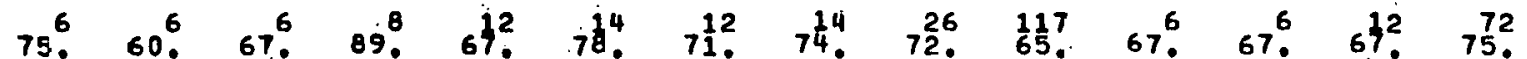

$25^{2} \quad 40^{4} \quad 22^{2} \quad 11^{1} \quad 33^{6} \quad 17^{3} \quad 24^{4} \quad 26^{5} \quad 25^{9} \quad 33^{5} \quad 11^{1} \cdot 33^{3} \quad 22^{4} \quad 22^{21}$

11. $\quad 6^{1} \quad 6^{1} \quad 3^{1} \quad 3^{5} \quad 22^{2} \quad$. $11^{2} \quad 3^{3}$

$\begin{array}{llllllllllllll}3.75 & 3.60 & 3.56 & 3.89 & 3.67 & 3.72 & 3.65 & 3.74 & 3.69 & 3.62 & 3.44 & 3.67 & 3.56 & 3.72\end{array}$

$\begin{array}{lllllllllllllll}.43 & .49 & .66 & .30 & .44 & .57 & .56 & .41 & .54 & .53 & .84 & .44 & .66 & .50\end{array}$

Figure F-1. Biomass Data Tables (continued) 


\begin{tabular}{|c|c|c|c|c|c|c|c|c|}
\hline & & & & & $T-S$ & & & \\
\hline & & & 10CTO & 9791 & & & & \\
\hline & & NFORME & DNESS & ION 31 & & & & \\
\hline $\begin{array}{l}\text { SIOM } \\
\text { SfTE } \\
\text { FORST } \\
\text { OFF }\end{array}$ & $\begin{array}{l}\text { RIOM } \\
\text { FRIV } \\
\text { FRSTR }\end{array}$ & $\begin{array}{l}\text { RIOM } \\
\text { PIORST } \\
\text { PRODD } \\
\text { ENG }\end{array}$ & ALL & $\begin{array}{l}\text { EIOM } \\
\text { EOUC }\end{array}$ & EEUCE & $\begin{array}{c}\text { BIOM } \\
\text { CES } \\
\text { CD } \\
\text { AGENT }\end{array}$ & $\begin{array}{l}\text { ALL } \\
\text { CES } \\
\text { CU } \\
\text { AGENT }\end{array}$ & $\begin{array}{l}\text { ALL } \\
\text { CEES } \\
\text { SPATE } \\
\text { SPEC }\end{array}$ \\
\hline 1009 & 1009 & 100 ? & 1096 & 1009 & $100^{63}$ & 1009 & 1045 & $100^{8}$ \\
\hline $44^{4}$ & $22^{2}$ & $75^{6}$ & $\begin{array}{l}35 \\
36\end{array}$ & $22^{2}$ & 491 & & $2^{1}$ & 44. \\
\hline $33^{3}$ & $67^{6}$. & $13^{1}$ & $\begin{array}{l}44 \\
46 .\end{array}$ & $67^{6}$. & $43^{27}$. & $22^{2}$ & $20^{\circ}$ & $39 ?^{7}$ \\
\hline $22^{2}$ & & 13. & $18 ?$ & $11^{1}$ & $8^{5}$ & 78 . & 73. & $17^{3}$ \\
\hline & $11{ }^{1}$ & & & & & & & \\
\hline & & & & & & & $4^{2}$ & \\
\hline 3.22 & 3.00 & 3.63 & 3.19 & 3.11 & 3.41 & 2.22 & 2.26 & 3.28 \\
\hline .79 & .81 & .66 & .70 & .57 & .6 & .42 & .46 & 2 \\
\hline
\end{tabular}

Figure F-1. Biomass Data Tables (continued) 
IOCTOBER, 1979 )

INTEREST IN SPECIFIED BIOMASS ENERGY AREAS (OUESTION 6)

BIOHASS ENERGY

GROHTH OR COLLECTION OF
BIOMASS MATERIALS

1. YES

2. NO

DONיT KNOW/NA

LIOUID FUESS FROM GIOMASS

1. $Y \equiv S$

2. ND

DON T KNOW/NA

GASES FROM BIOMASS MATERIALS

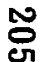

$$
\text { 1. YES }
$$

2. ND

DDN T. HNOW/NA

BURNABLE PELLETS. ETC. FROM

1. YES

2. NO

DON-T K.NOH/NA

RESIDENTIAL BURNING OF WOOD

1. YES

2. N10

CON T KENOW/NA

COMMECIAL OR INOUSTRIAL
BURNING OF BIOMASS

1. YES

2. 110

DON I RNOW/NA

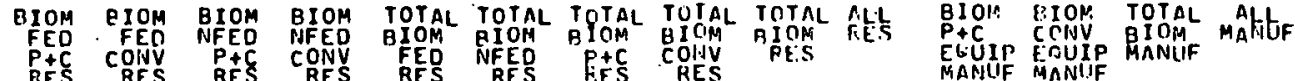

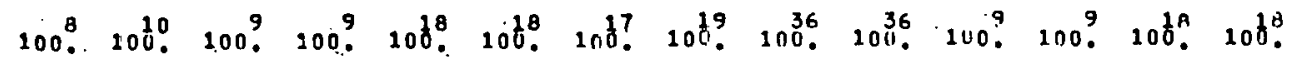

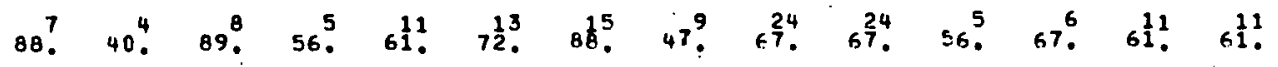

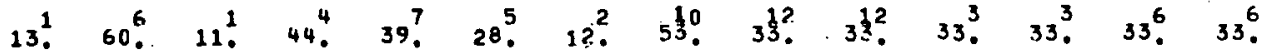
11 . $6 ! \quad 6 !$

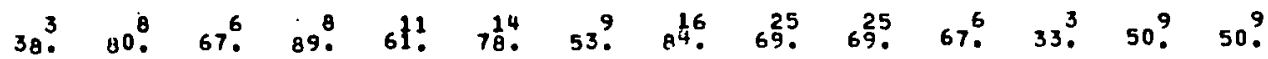

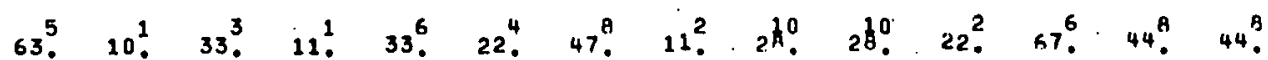

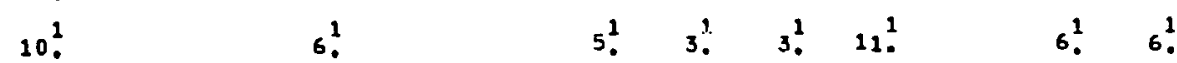

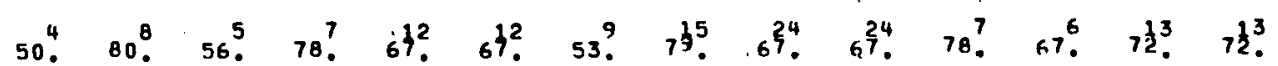

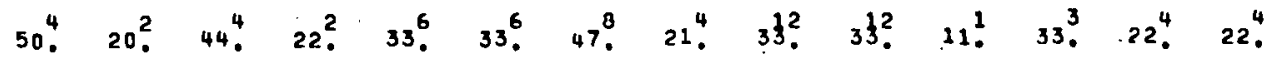
11. . . 6 . 6 .

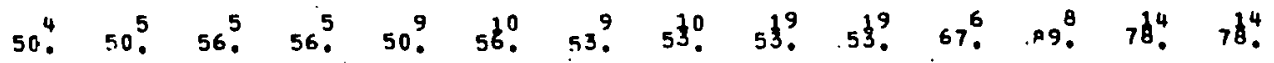

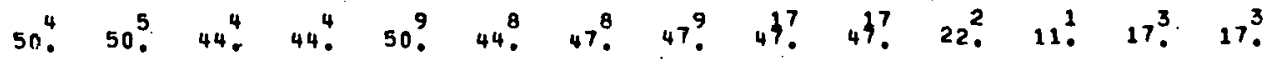
$11^{1} .6$. 6 ?

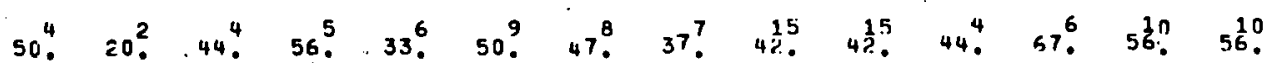

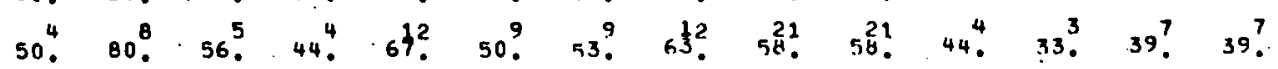
11 6: 6?

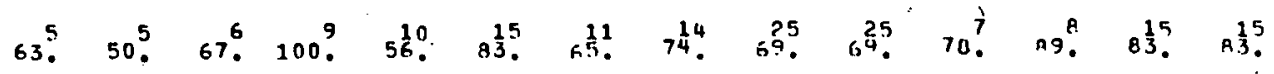

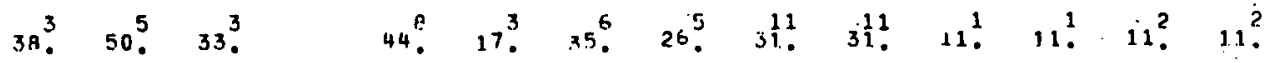

Figure F-1. Biomass Data Tables (continued) 
(OCTOEER, 1979!

INTEREST IN SPECIFIED BIOMASS ENERGY AREAS ¿QUESTION G)

BIOMASS ENERGY (CONTINUED)

GROWTH OR GOLLECTION OF
BIOMASS WATERALS

1. $r \equiv S$

2. NJ

DJN"T KNOW/NA

LIQUID FUELS FROM BIOMASS

1. YES

2. ND

DON T KNOW/NA

GASES FROM GIOMASS MATCRIALS
1. TES

2. 10

DON.T KNOW/NA

BURNABLE PELLETS, ETR. FROM
BIOMASS

1. TES

2. 10

DON T KNOW/NA

RESIOENTIA EURNING OF NCOOO
1. res

2. NO

CON'T KNOW/NA

COMMECIAL OR INDUSTRIA
BURNING OF BIOMASS

$$
\text { 1. NES }
$$

2. P.O

CONTT KNOW/NA

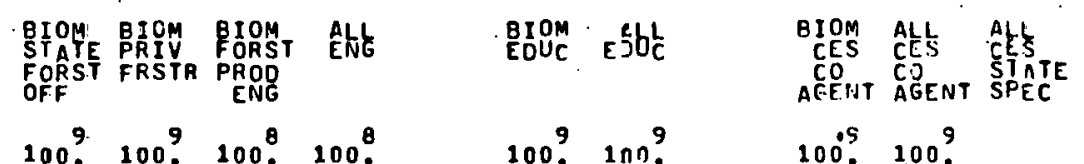

100 . 100 . $100^{8} .100 .0100$. $100^{9}$. $100^{\circ} .100$.

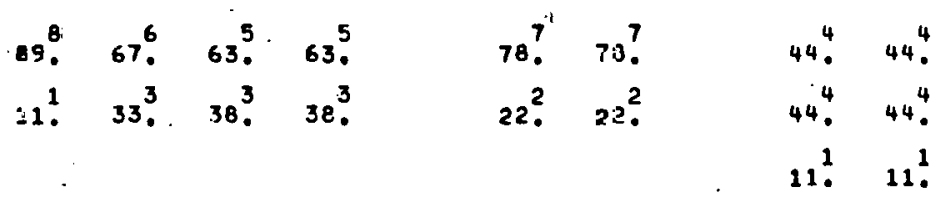

$788^{7} \quad 22^{2} \cdot 63^{5} \quad 63^{5}$

$78.793 ?$

$89.899^{\text {. }}$

$22.67^{2} .38^{3} .38$.

$22.2 ?^{2} \cdot$

11. 11 .

21 .

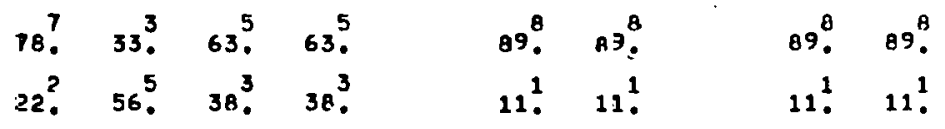

11 .

39. $78^{7}, \quad 75^{6}, \quad 75^{6}$

$56.56^{5} \cdot$

$44^{4} \cdot .44^{4}$.

11. 11. $255^{2} 25$ ?

$44^{4} .44$.

11 .

44.54.

11.211.

99. $33^{3} .50 .450^{4}$.

$100^{9} .10 n^{9}$ ?

67. 67.

11. $.67^{6} .50^{4} . \quad 50^{4}$

33. $33^{3}$

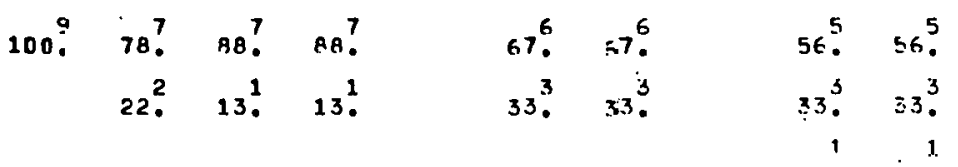

Figure F-1. Biomass Data Tables (continued) 
(OCTOBER, 1979)

USEFULNESS OF SPECIFIED INFORMATION ITEMS (OUESTION B)

BIOMASS ENERGY

OBAIII BIBLIOGRAPHY

ESSENTIAL

VERY USEFUL

SOMEWHAT USEFUL.

NOT AT ALL USEFUL

ESSEFULIIAL + VERY

DONOT KNOW

AVERAGE

STANDARD DEVIATION

QBAIZI LIST OF SOURCES

ESSENTIAL

VERY USEFUL

SOMEWHAT USEFUL

NOT AT ALL USEFUL

ESSENTIAL + VERY

DONPT KNOW.

AVERAGE

STANDARO DEVIATION
BIOM BIOM BIOM BIOM TOTAL TOTAL TOTAL TOTAL TOTAL RLL RES CONES RES CONES RES RES PES CONES

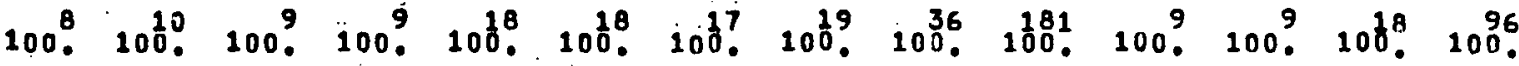

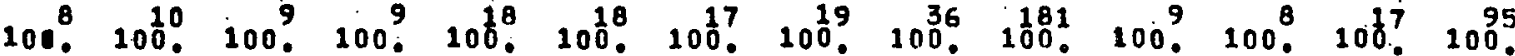

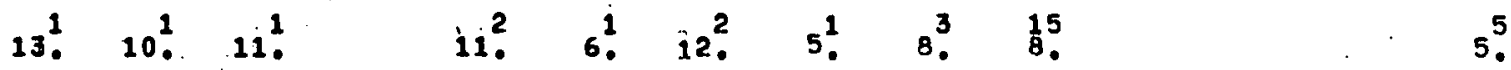

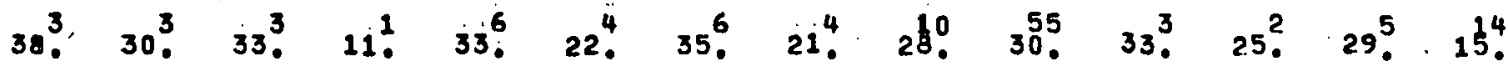

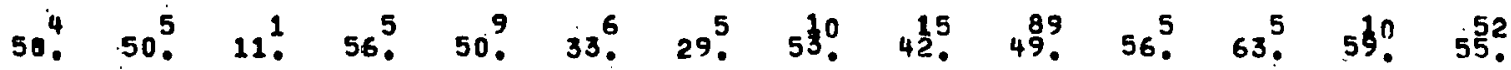

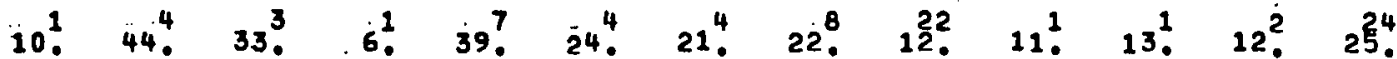

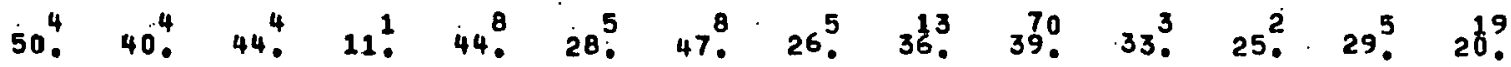

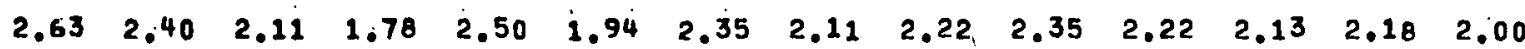

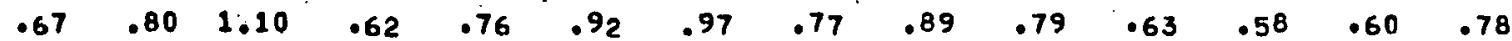

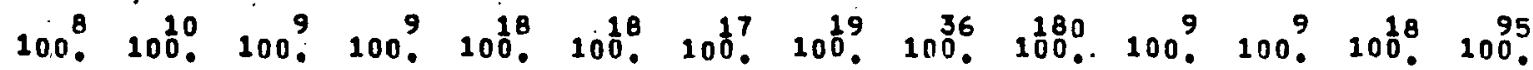

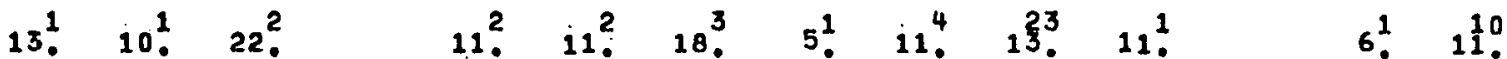

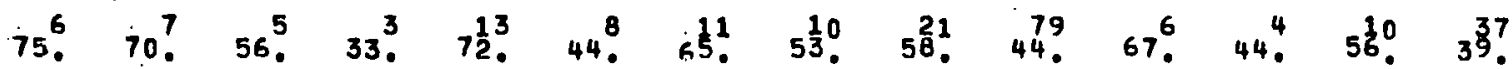

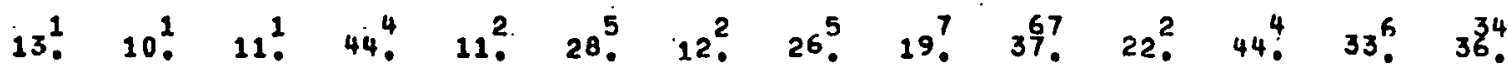

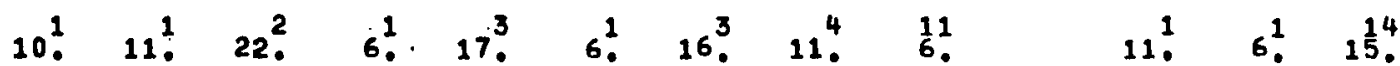

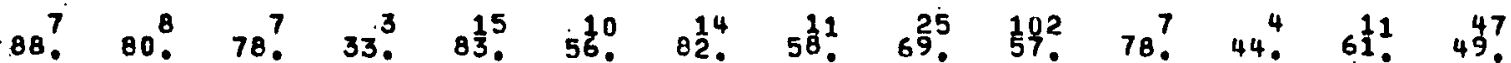

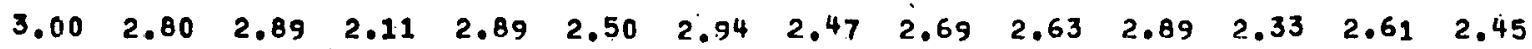

$\begin{array}{llllllllllllll}.50 & .74 & .87 & .74 & .65 & .89 & .73 & .82 & .82 & .79 & .56 & .67 & .68 & .87\end{array}$

SCALE: ESSENTIAL $=4$, VERY USEFUL $=3$, SOMEWHAT' USEFUL $=2$, NOT AT ALL USEFUL $=1$

Figure F-1. Biomass Data Tabies (continued) 
10CTOEER, 19791

USEFULNESS OF SPECIFIEC INFOFMATION ITEMS (QUESTION B)

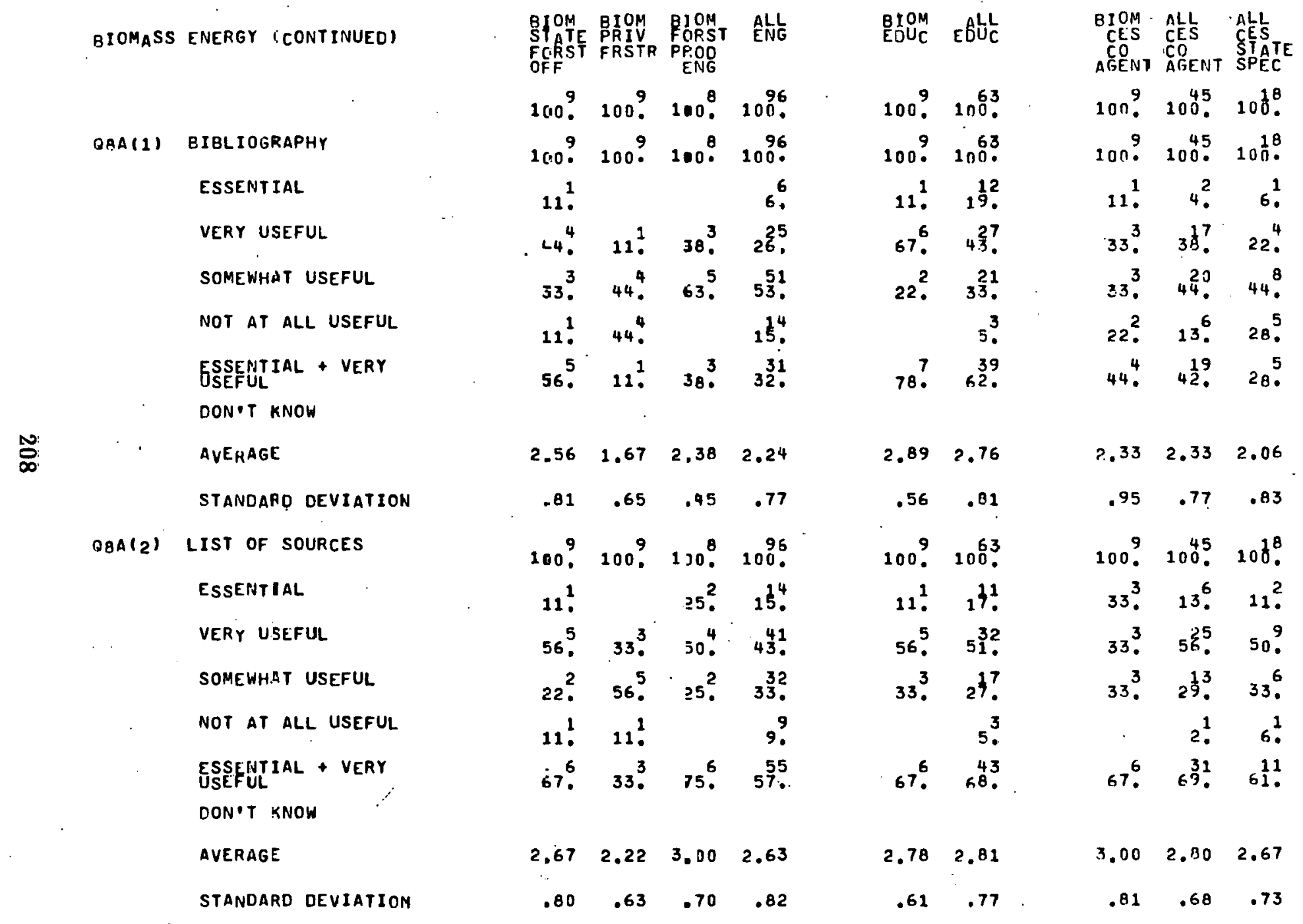

BIOY SHAC

OWINER OWNER

100 ? 100 .

100 ? 100 ?

100. 100.

11 .

14. 11 .

43. $44^{4}$.

29 ? 33 ?

14. $22^{2}$.

$140^{2}$.

$1.83 \quad 2.00$

$.69 \quad .94$

100 ? 100 ?

22 .

43. 22 .

37. $44^{4}$

11 .

43. $44^{4}$.

$2.43 \quad 2.56$

$.48 \quad .96$

STALE: ESSENTIAL $=4$, VERY USEFUL $=3$, SOMEWHAT USEFU: $=2$, VOT AT ALL USEFUL $=1$

Figure F-1. Biomass Data Tables (continued) 
COCTOBER, 1979 )

USEFULNESS OF SPECIFIED INFORMATION ITEMS - CONTINUED (QUESTION B)

BIOMASS ENERGY

BIOM BIOM BIOM BIOM TOTAL TOTAL TOTAL TOTAL TOTAL ALL

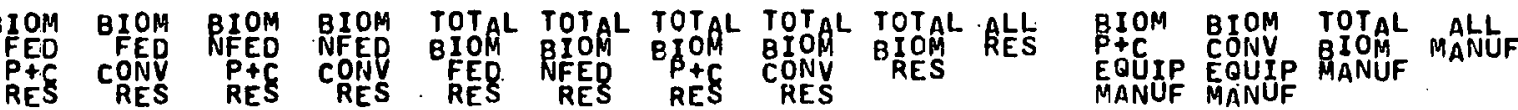

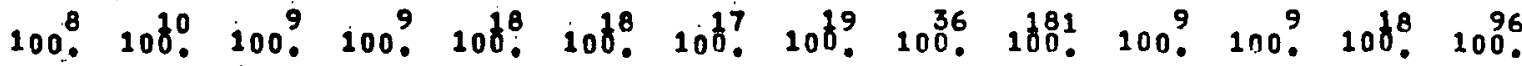

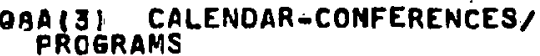

ESSENTIAL

VERY USEFUL

SOMEWHAT USEFUL

NOT AT ALL USEFUL

ESSEENTIAL + VERY

DON? KNOW

STANDARD DEVIATION

QBA. 41 DIAGRAMS/SCHEMATICS

ESSENTIAL

VERY USEFUL

SOMEWHAT USEFUL

NOT AT ALL USEFUL

ESSEFULIAL + VERY.

DON'T KNOW

AVERAGE

STANDARD DEVIATION

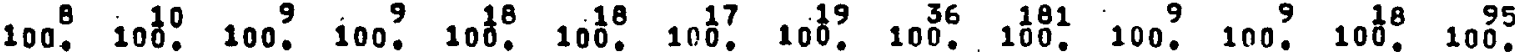

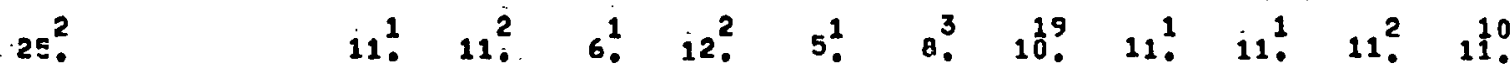

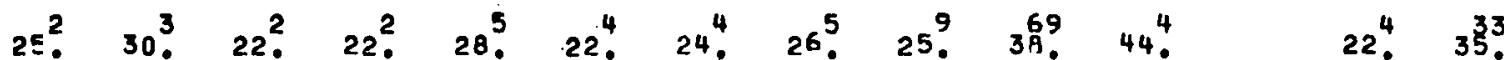

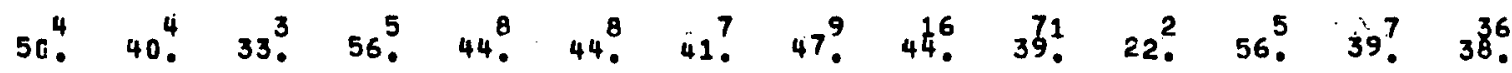

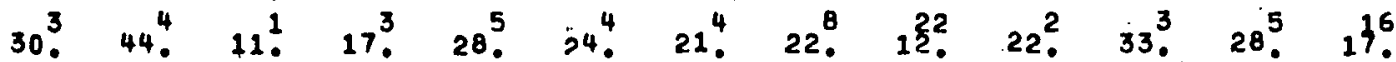

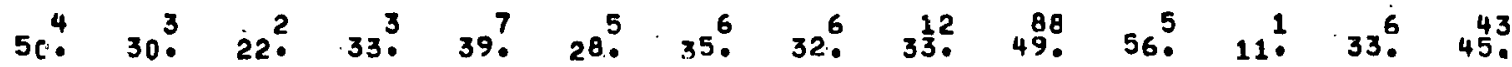

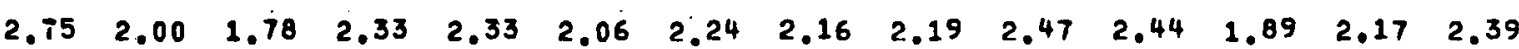

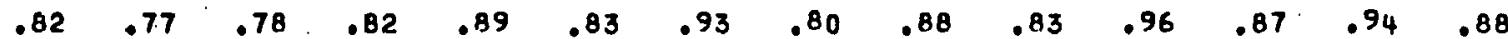

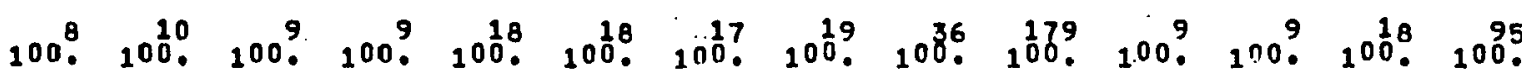

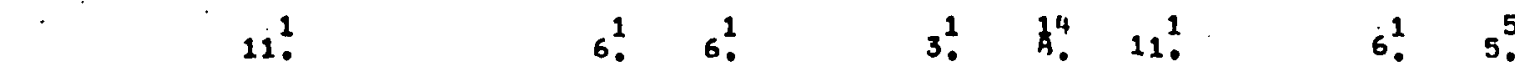

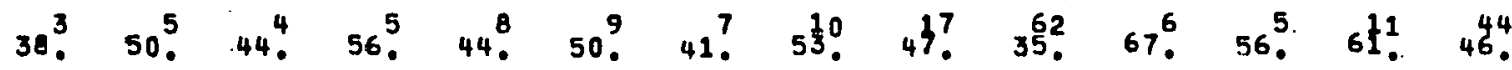

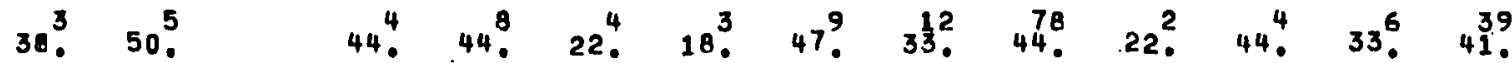

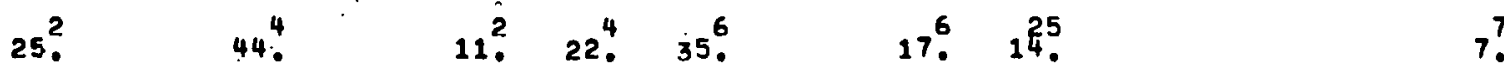

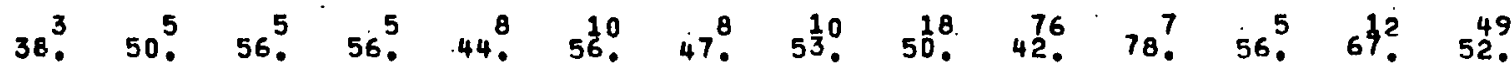

$\begin{array}{llllllllllllll}2.13 & 2.50 & 2.22 & 2.56 & 2.33 & 2.39 & 2.18 & 2.53^{\circ} & 2.36 & 2.36 & 2.89 & 2.56 & 2.72 & 2.49\end{array}$

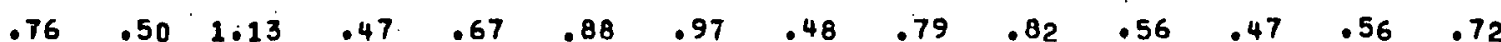

SCALE: ESSENTIAL $=4$, VERY USEFUL $=3$, SOMEHHAT USEFUL $=2$, NOT AT ALL USEFUL $=1$

Figure F-1. Blomass Data Tables (continued) 


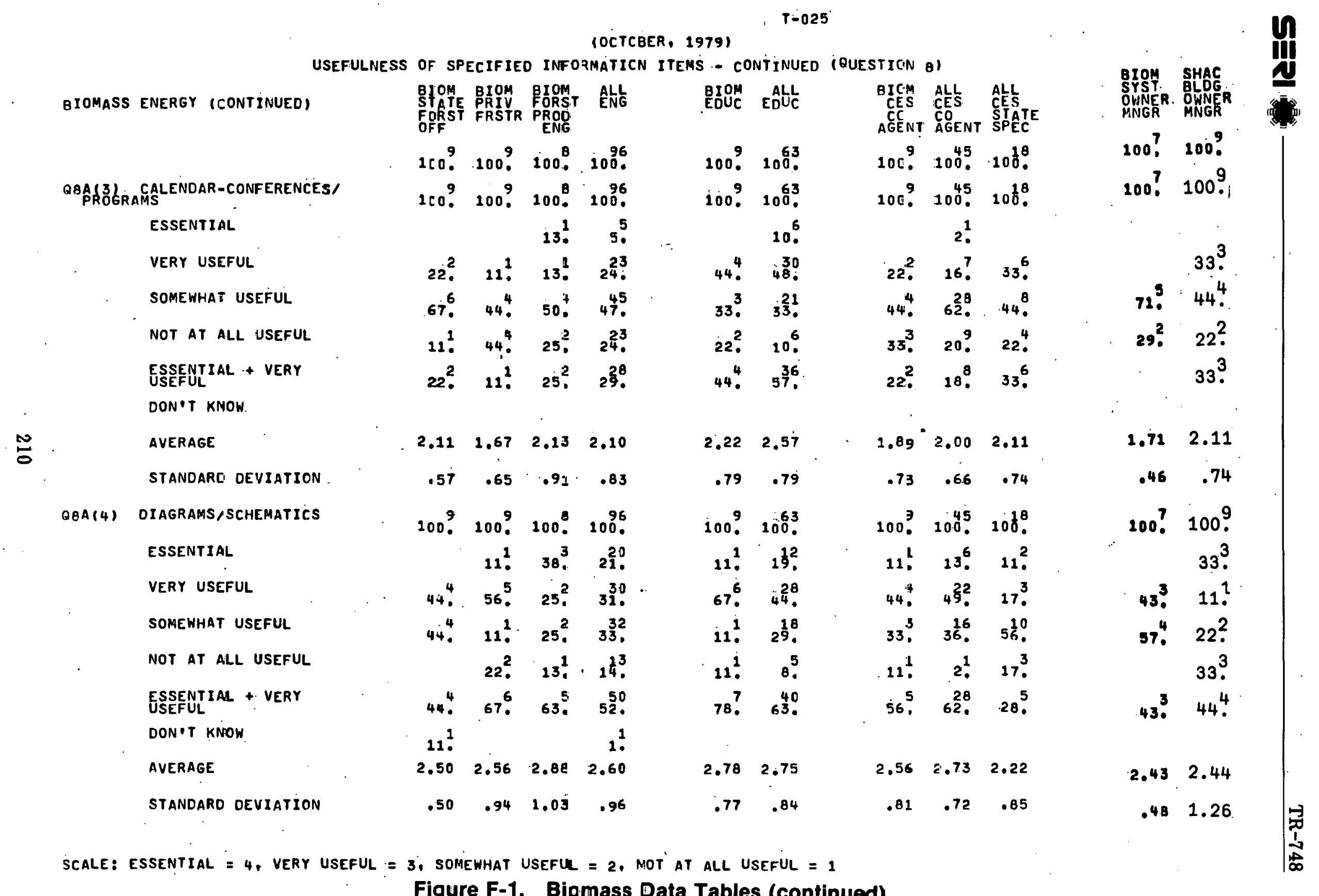

Figure F-1. Biomass Data Tables (continued) 
IOCTOBER, 1979)

USEFULNESS OF SPECIFIED INFORMATION ITENS - CONTINUED (QUESTION 8 )

BIOMASS ENERGY

QAA.SI DE NON-TECHNICAL

ESSENTIAL

VERY USEFUL

SOMEWHAT USEFUL

NOT AT ALL USEFUL

ESSENTIIAL + VERY

DON'T KNOW

AVERAGE
STANDARD DEVIATION

gBa(6) TECHNICAL DESCRIPTION

ESSENTIALL

VERY USEFUL

SOMEWHAT USEFUL

NOT AT ALL USEFUL

ESSENTIAL + VERY DON'T KNOW

AVERAGE

STANDARD DEVIATION

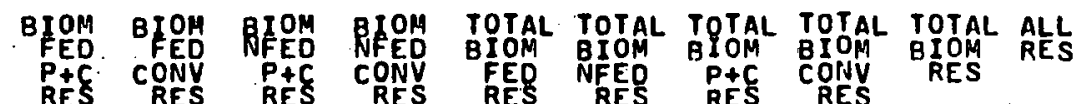

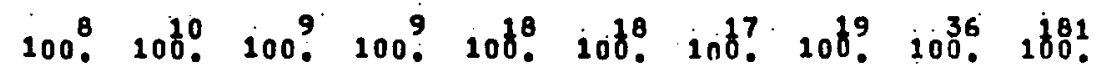

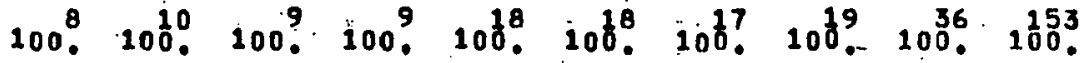

11. $\quad 66^{1} \quad 6_{0}^{1} \quad 3_{0}^{1} 2^{3}$.

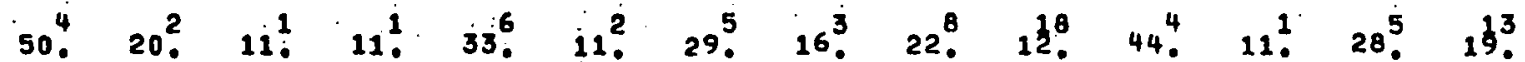

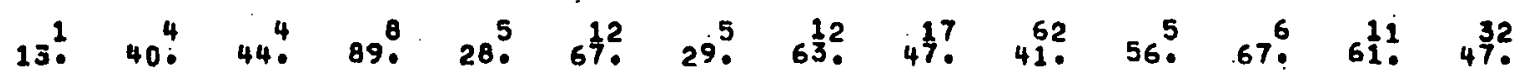

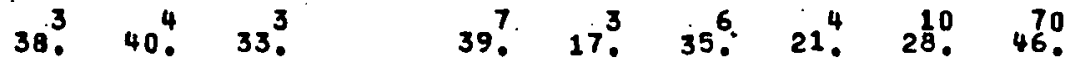
$50^{4} \quad 20^{2} \quad 22^{2} \quad 11^{1} \quad 33^{6} \cdot 17^{3} \quad 35^{6} \quad 16^{3} \quad 25^{9} \quad 14^{2} \quad 44^{4} \quad 11^{1} \quad 28^{5} \quad 24^{16}$

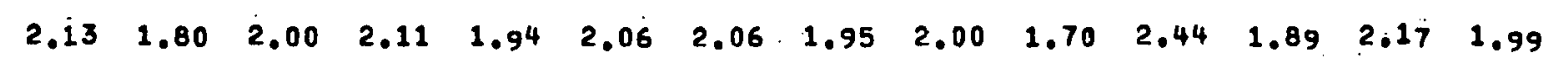
$\begin{array}{llllllllllllll}.92 & .74 & .94 & .32 & .85 & .69 & .93 & .59 & .78 & .74 & .51 & .56 & .58 & .80\end{array}$

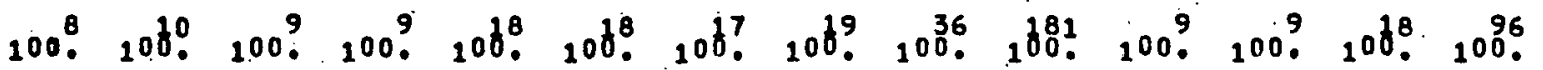
$25^{2} \quad 11^{1} \quad 11^{1} \quad 11^{2}-11^{2} \quad 18^{3} \quad 5^{1} \quad 11^{4} \quad 10^{8} \quad 22^{2} \quad 11^{1} \quad 17^{3} \quad 14^{13}$

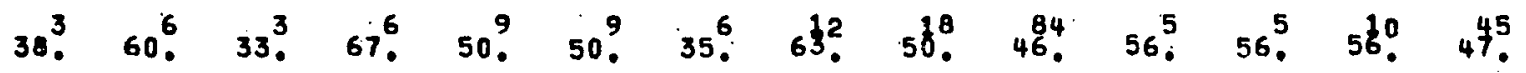

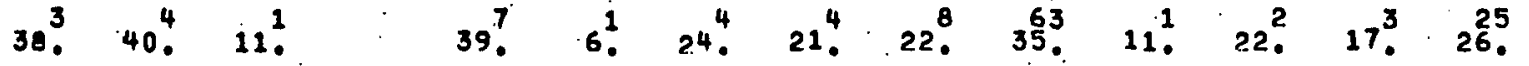

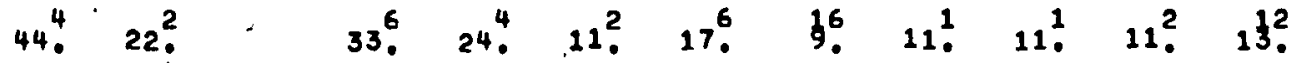

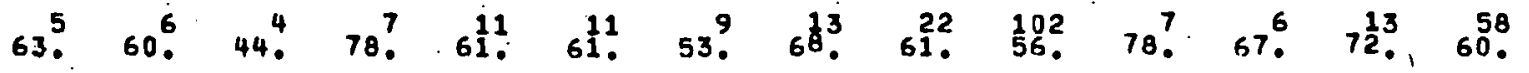

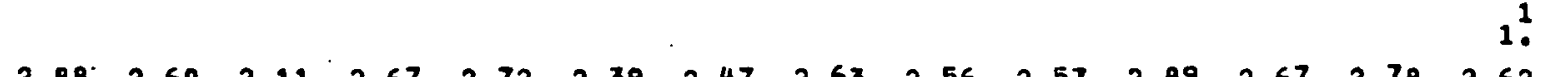
$\begin{array}{lllllllllllllll}.76 & .49 & 1.10 & .93 & .65 & 1.05 & 1.03 & .74 & .88 & .80 & .87 & .00 & .84 & .87\end{array}$

OIOM TOTAL MALL 
(OCTCBER, 1979)

USEFULNESS OF SPECIFIED INFCRIAATICN ITEMS - CONTINUED (QUESTION B)

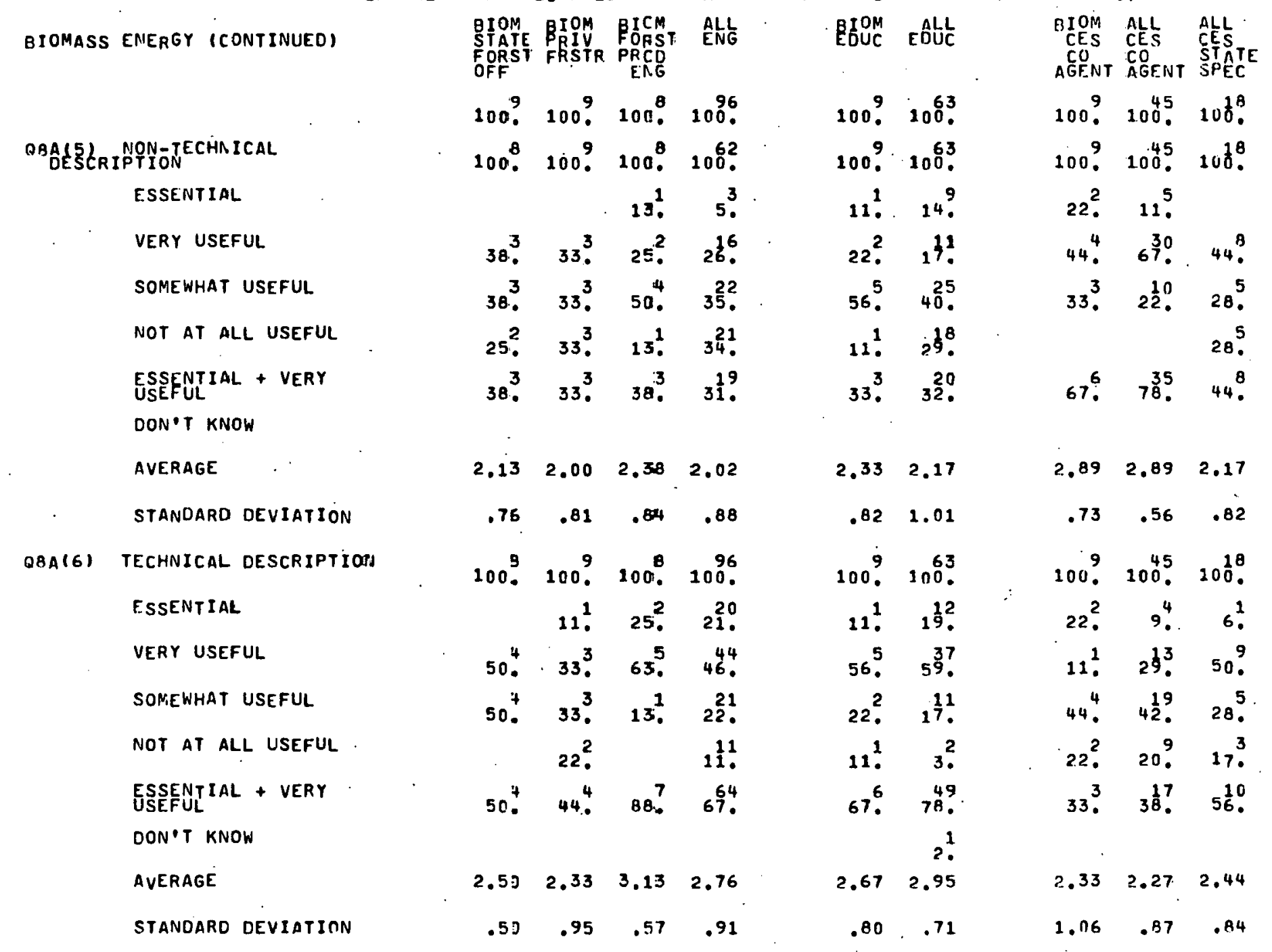

SCALE: ESSENTIAL $=4$, VERY USEF $J$ L $=3$, SOAEWHAT USEF $J L=2$, NOT AT ALL USEFUL $=1$ 
(OCTOBER, 1979)

USEFULNESS OF SPECIFIED INFORMATION ITEMS - CONTINUED (QUESTION \&)

BIOMASS ENERGY

BIO4 BIOM BIOM BIOM TOTAL TOTAL TOTAL. TOTAL TOTAL ALL

FED FED NFED NFED BIOM BIOM B OOM BIOM BIOM RES BIOM BIOM TOTAL MALL EUIP EOUIP MaNUF

MANOF MANOF

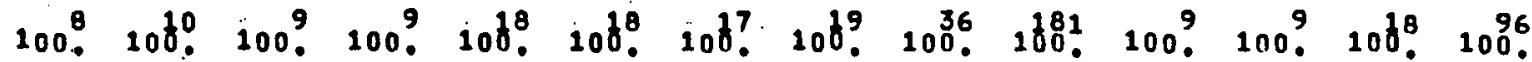

QBAITI LISTS OF SUPPLIERS

ESSENTIAL

VERY USEFUL

SOMEHHAT USEFUL

NOT AT ALL USEFUI

ESSENTIAL + VERY

DON'T KNOW

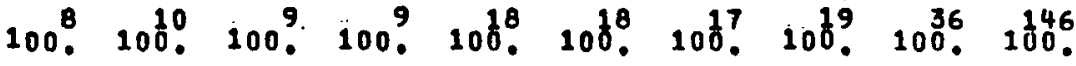

1009 . $1009.100^{8}$. $100^{96}$.

AVERAGE

STANNDARO DEVIATEON

$13^{2}$

22.

$6_{6}^{1} \quad 11^{2} \quad 180^{3}$

$8^{3} \quad 1^{2}$.

33. $27^{3} \cdot 20^{9}$.

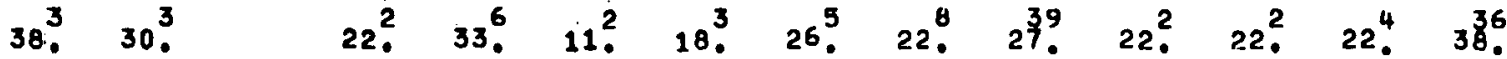

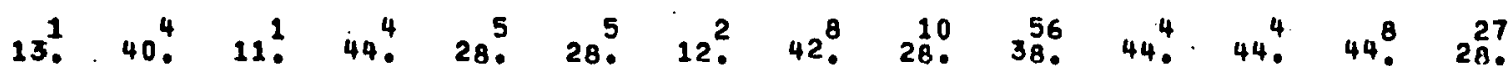

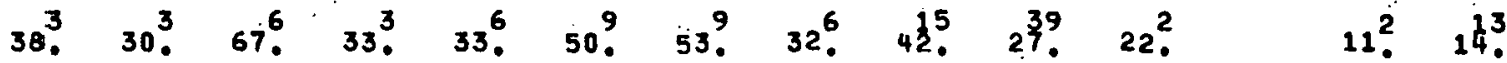

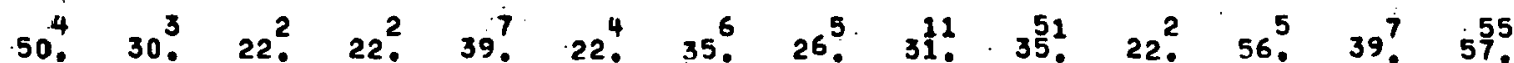

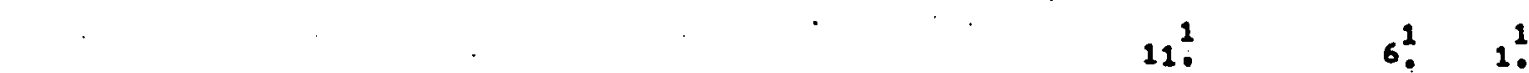

$\begin{array}{llllllllllllll}2.25 & 2.00 & 1.78 & 1.89 & 2.11 & 1.83 & 2.00 & 1.95 & 1.97 & 2.16 & 2.00 & 2.89 & 2.47 & 2.64\end{array}$

$\begin{array}{llllllllllllll}1.08 & .77 & 1.22 & .73 & .93 & 1.02 & 1.18 & .75 & .99 & .92 & .70 & .87 & .91 & .95\end{array}$

QBACB) HANDBOOKS/TABLES

ESSENTIAL

VERY USEFUL

SOMEWHAT USEFUL

NOT AT ALL USEFUL

ESSEEYTIAL + VERY

DONPT KNOW

AYERAGE

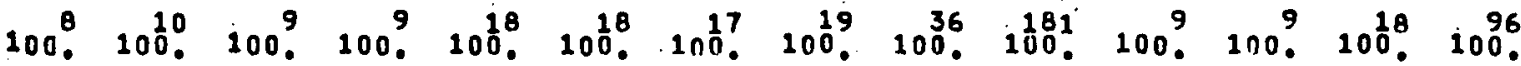

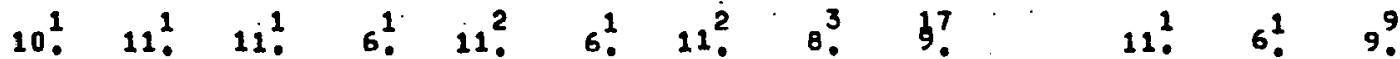

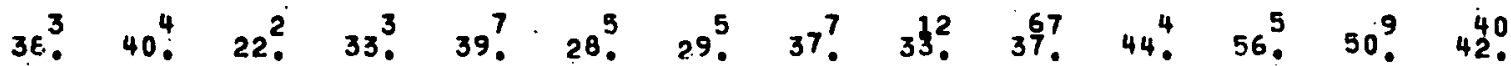

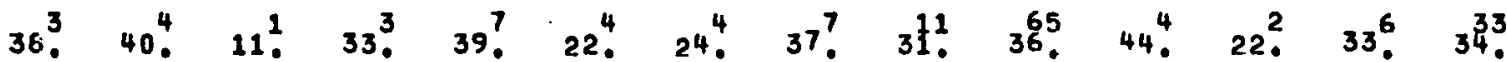

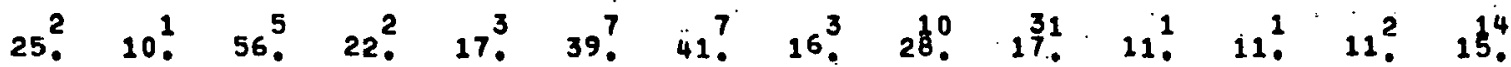

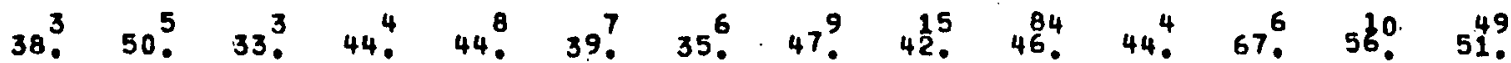

STANDARD DEVIATION 
(OCTOBER, 1979)

USEFULNESS OF SPECIFIED INFOPMATION ITEMS - CONTINUED (QUESTION G)

BIOMASS ENERGY (CONTINUED)

DBA(7) LISTS OF SUPPLIERS ESSENTIAL.

VERY USEFUL

SOMEWHAT USEFUL

NOT AT GLL USEFUL

ESSENTILAL + VERY DON'T KNOW

\section{AVERAGE}

STANDARI OEVIATION

QBA(B) HANDBOOKS/TABLES

\section{ESSENTIAR}

VERY USEFUL

SOMEWHAT USEFUL

NOT AT ALL. USEFUL

ESSEEULIAL + VERY

DON'T KNOW

AVERAGE

STANDARD DEVIATION

\begin{tabular}{|c|c|c|c|c|c|c|c|c|}
\hline $\begin{array}{l}\text { BICM } \\
\text { STCTE } \\
\text { FoF S } \\
\text { OFF }\end{array}$ & $\begin{array}{l}\text { BIOM } \\
\text { PKIV } \\
\text { FRSTR }\end{array}$ & $\begin{array}{l}\text { EIOM } \\
\text { FORST } \\
\text { PROD } \\
\text { ENG }\end{array}$ & ELL & $\begin{array}{l}\text { BIOM } \\
\text { EDUC }\end{array}$ & ED̂UC & $\begin{array}{c}\text { BIOM } \\
\text { CES } \\
\text { CO } \\
\text { AGENT }\end{array}$ & $\begin{array}{l}\text { RLL } \\
\text { CESS } \\
\text { CO } \\
f, G E . N T\end{array}$ & $\begin{array}{l}\text { ALL } \\
\text { CES } \\
\text { SIJATE } \\
\text { SPEC }\end{array}$ \\
\hline $100^{\circ}$ & $100^{9}$ & $100^{8}$. & 1006. & 1009 & 1063 & 1009 & 100. & $100^{18}$ \\
\hline 1009 & 1009 & $100^{\circ}$ & 1096 & 1009 & $100^{63}$ & $100^{9}$ & $10 n^{45}$ & $100^{18}$ \\
\hline $2 z^{2}$. & & $13^{2}$ & 11. & & $14^{9}$. & 11. & $13^{6}$ & 6. \\
\hline $33^{3}$. & $33^{3}$. & $25^{2}$. & $27^{6}$. & $44^{4}$. & 352 & 56. & 422 & $33^{6}$. \\
\hline 3.3. & $44^{4}$. & $50^{4}$. & 34. & $33^{3}$. & 320. & $33^{3}$. & $33^{\frac{15}{3}}$. & $28^{5}$ \\
\hline $11 !$ & $22^{2}$. & $13^{1}$ & 27. & $22^{2}$ & 19. & & $4 ?$ & $33^{6}$ \\
\hline 56. & $33^{3}$. & 38. & 39. & $44^{4}$. & 49. & 67.6 & 620. & $39 ?$ \\
\hline 2.67 & 2.11 & 2.38 & 2.23 & 2.22 & 2.44 & 2.78 & 2.71 & 2.11 \\
\hline .93 & .74 & .84 & .97 & .79 & .96 & .61 & .75 & .93 \\
\hline 100. & $100 ?$ & $100^{8}$ & 1095 & .1009 & $100^{63}$ & 1009 & $100^{45}$ & 10017 \\
\hline 13! & & $30^{3}$. & 187 & $22^{2}$. & $22^{14}$ & $11^{3}$ & $7^{3}$ & $12^{2}$ \\
\hline $25{ }^{2}$ & $33^{3}$ & $3 \theta^{3}$. & $\begin{array}{r}45 \\
47 .\end{array}$ & $44^{4}$. & 40. & $44^{4}$. & $4 \overrightarrow{9}$. & $24^{4}$. \\
\hline 63. & $33^{3}$ & $25{ }^{2}$ & 29. & $22^{2}$ & 3? & 33. & 36. & $47^{8}$. \\
\hline & $33^{3}$ & & $5^{5}$ & $11 !$ & $66^{4}$ & 11 . & $9^{4}$ & $188^{3}$ \\
\hline $38{ }^{3}$ & $33^{3}$ & $75^{6}$. & 652 & $67^{6}$. & 62. & 56. & $5 \frac{25}{5}$ & $35^{6}$. \\
\hline 2. & 2.00 & 3.13 & 2.78 & 2.78 & 2.78 & 2.56 & 2.53 & 2.29 \\
\hline & .81 & .76 & .79 & $: 90$ & .85 & .81 & .75 & .90 \\
\hline
\end{tabular}

Figure F-1. Biomass Data Tables (continued) 
(OCTOBER, 1979)

USEFULNESS OF SPECIFIED INFORMATION ITEMS - CONTINUED (OUESTION $\beta$ )

BIOMASS ENERGY BIOM BIOM BIOM BIOM TOTAL TOTAL TOTAL TOTAL TOTAL ALL PEC CONV P PE CONV FED NFED P+C CONV RES
RES RES RES RES RES RES RES RES

BIOM BIOM TOTAL. MALL EUUIP EOUIP MANUF

MANUF MANUF

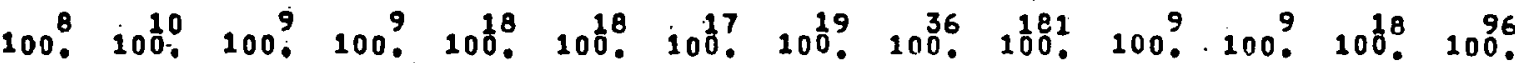

QRA(9) TECHNICAL EXPERTS LIST

ESSENTIAL

VERY USEFUL

SOMEWHAT USEFUL

NOT AT ALL USEFUL

ESSENTIAL + VERY

DON'T KNOW

AVERAGE

STANOARD CEVIATION

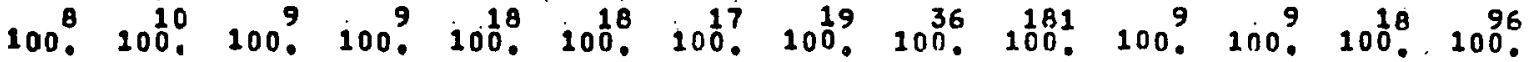

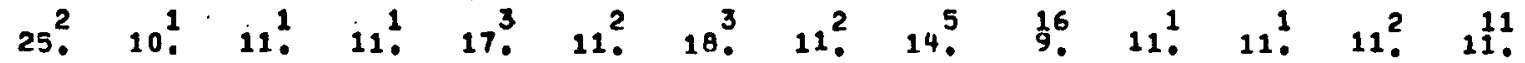

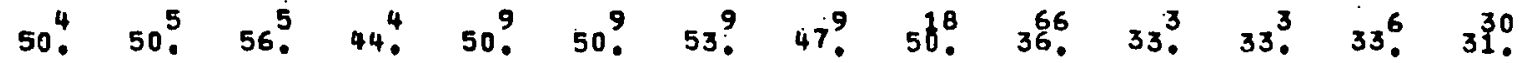

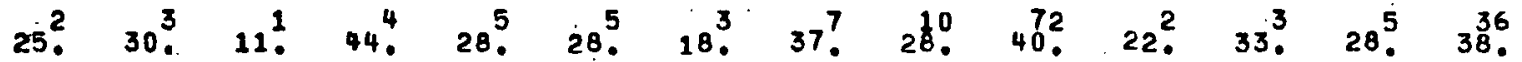
$10^{3} \quad 22_{0}^{2} \quad 6_{0}^{1} \quad 11_{0}^{2} \quad 12_{0}^{2} \quad 5_{0}^{1} \quad 8_{0}^{3} \quad 15_{0}^{27} \quad 33^{3} \quad 22_{0}^{2} .28_{0}^{5} \quad 20^{19}$.

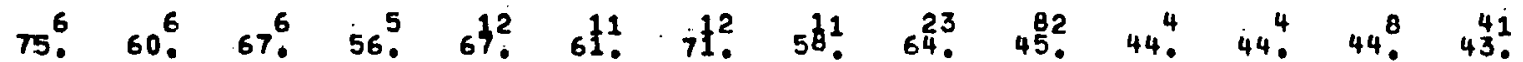

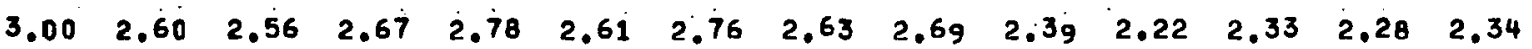

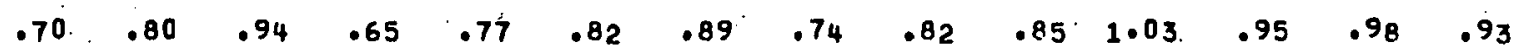

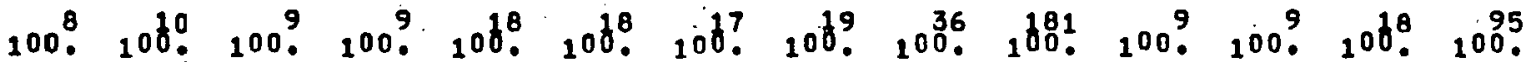
ESSENTIAL

VERY USEFUL

SOMEHHAT USEFUL

NOT AT ALL USEFUL.

ESSENTIAL + VERY

DON'T KNOW

AVERAGE

STANDARD OEVIATIION

\begin{tabular}{|c|c|c|c|c|c|c|c|c|c|c|c|c|c|}
\hline & $20^{2}$ & $1 i^{1}$ & $11^{1}$ & $21^{2}$ & $11^{2}$ & $6^{1}$ & $.16^{3}$ & $11^{4}$ & $\begin{array}{r}30 \\
65\end{array}$ & $22^{2}$ & $22^{2}$ & $22^{4}$ & $\begin{array}{r}20^{9} \\
34\end{array}$ \\
\hline $25 ?$ & 40. & $22^{2}$ & $560^{\circ}$ & $33^{6}$ & 39. & 24. & $47 ?^{9}$ & $3 \frac{13}{}$. & 36. & $22^{2}$ & 44. & $33^{6}$ & 36. \\
\hline $50^{4}$. & $30^{3}$ & $22^{2}$ & $33^{3}$ & 39 ? $^{7}$ & $28^{5}$ & $35^{6}$. & $32^{6}$ & $33^{2}$ & $29^{53}$ & $56^{5}$ & $22^{2}$ & $399^{7}$ & $27^{\circ}$. \\
\hline $25^{2}$ & $10^{1}$ & $44^{4}$. & & $17^{3}$ & $22^{4}$. & $35^{6}$. & $5^{1}$ & $19 ?^{7}$ & $\begin{array}{r}33 \\
18 .\end{array}$ & & $11^{1}$ & $6 !$ & $17^{16}$. \\
\hline $25^{2}$ & $60^{6}$. & $33^{3}$ & $67^{6}$ & $44^{8}$ & $50{ }^{9}$ & $29^{5}$ & $63^{12}$ & $47 ?$ & 525 & $44^{4}$. & $67^{6}$. & ${ }_{5}^{100}$. & $\begin{array}{r}53 \\
56 .\end{array}$ \\
\hline & 2.70 & .00 & 2.78 & 2.39 & 2.39 & 2.00 & 2.74 & 2.39 & 2.51 & 2.67 & .78 & 2.72 & 2.59 \\
\hline 7 & 9 & .05 & .61 & 38 & .94 & .90 & .77 & 91 & .96 & .80 & 90 & 87 & \\
\hline
\end{tabular}


(OCTOBER, 1979$)$

USEFULNESS OF SPECIFIED INFORMATION ITEMS - CONTINUED (QUESTION E)

BIOMASS ENERGY (CONTINUED)

ESSENTIAL

VERY USEFUL

SOMEWHAT USEFUL

NOT AT ALL USEFUL

ESSENTIAL + VERY

DON'T KHOW

定

AVERAGE
STANDARO OEVIATION
QAA(10) MANUAL METHODS
ESSENTIAL
VERY USEFUL
SOMEWHAT USEFUL
NOT AT ALL USEFUL
ESSENTIAL + VERY,
USEFUL
DON T KNOW
AVERAGE
STANDARD OEVIATION

STANDARD DEVIATION
BICM BIOM BIOM ALL ATS BIOM EALL

$$
\begin{array}{lrr}
9 & 9 & 0
\end{array}
$$

$100^{9} \cdot 1009.100 \% 1006$

100.1009 .100 .1006

11. 11. $25^{2}$. 9?

$7 E^{7} \cdot 22^{2} \quad 13^{1} \quad 2^{27}$.

$44^{4} .38^{3}, 46^{4}$.

$11^{1} .22^{2}, 25^{2}, 13^{6}$

89. $33^{3} . \quad 30^{3} . \quad 38^{36}$

$2.89 \quad 2.22 \quad 2.38 \quad 2.30$

$\begin{array}{llll}.13 & .92 & 1.10 \quad .86\end{array}$

100 . 100 ? $100^{8}, 100^{96}$.

$11^{1} \quad 33^{3}, 20^{9}$ ?

33. 11 ! $53^{4}, 47^{45}$

$44^{4} \cdot 22^{2} \cdot 13^{1}, 28^{27}$.

$22^{2} .44^{4}$. 5 .

33. $222^{2} .63^{7}, \quad 67^{64}$.

$$
11 .
$$

$2.11 \quad 1.88 \quad 3.25 \quad 2.81$

$\begin{array}{llll}.74 & 1.04 \quad .56 \quad .81\end{array}$
$100^{9} \cdot 10^{63}$.

1009.100 .3

11. $11^{7}$.

44. 3 s. $^{2}$.

$33 . \quad 48^{30}$

11 . 11?

56.526

$2.56 \quad 2.41$

$.81 \quad .83$

$1009.200^{6}$.

$22^{2} \cdot 24^{15}$.

22. $40^{25}$.

33. 25.

22. $10^{6}$.

$44^{4} .630$

2.

$2.44 \quad 2.79$

$1.07 \quad .91$
RIOM ALL ALL
CES CES SES
CEO CESTE
AEENT REENT SPEC

$100^{9} 10^{45} \cdot 100^{8}$.

$100 \% 100.100^{48}$.

7. 6 .

$22^{2} .33^{5} .33^{6}$

$56.4 \frac{19}{2} .39$.

22. $10^{8} .22^{4}$.

$22^{2}$ : $0^{8} \cdot 39^{7}$.

$\begin{array}{lll}2.00 & 2.29 & 2.22\end{array}$

$.66 \quad .83 \quad .85$

1009 : $104.100^{18}$

4. 6 ?

22. $2^{2}$. 39 ?

$44^{4}$ !18 $33^{6}$.

$33^{3}$ : $2^{6} \quad 22^{4}$.

22. 4. $44^{2}$.

$1.892 .38 \cdot 2.28$

$.73 \quad .76 \quad .86$
BJOM SHAC

MWNGE OWNER

100 ? 100 .

100 . 100 ?

$22^{2}$.

57. 11.

14. $44^{4}$.

29. $22^{2}$.

$57^{4} .33^{3}$.

$2.29 \quad 2.33$

$.86 \quad 1.05$

$100 ? 100$ ?

$11^{1}$.

$29^{2} .33^{3}$.

43. $44^{4}$.

14: 11 !

29. $44^{4}$.

14 .

$2.17 \quad 2.44$

$.67 \quad .83$

Figure F-1. Biomass Data Tables (continued) 


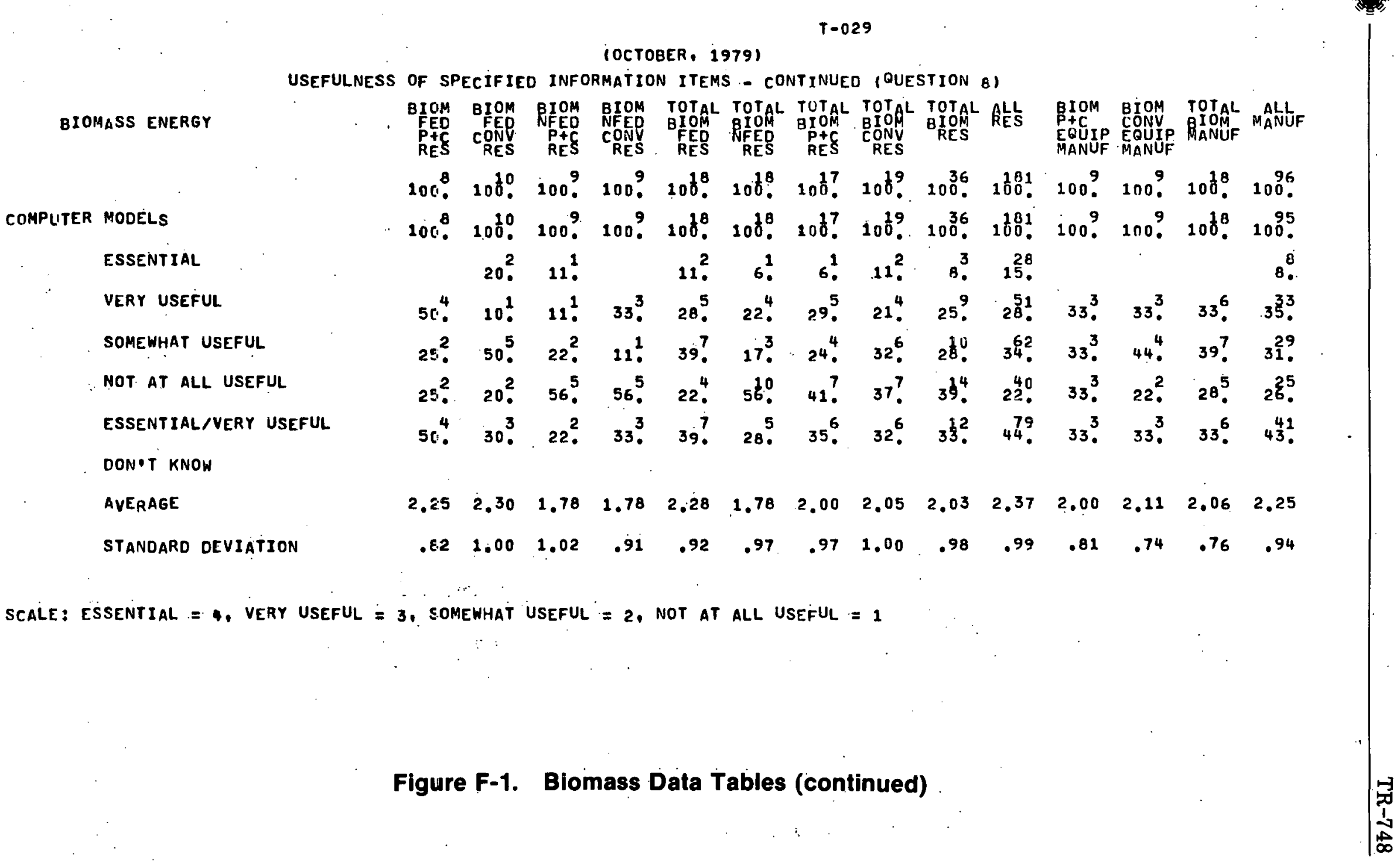




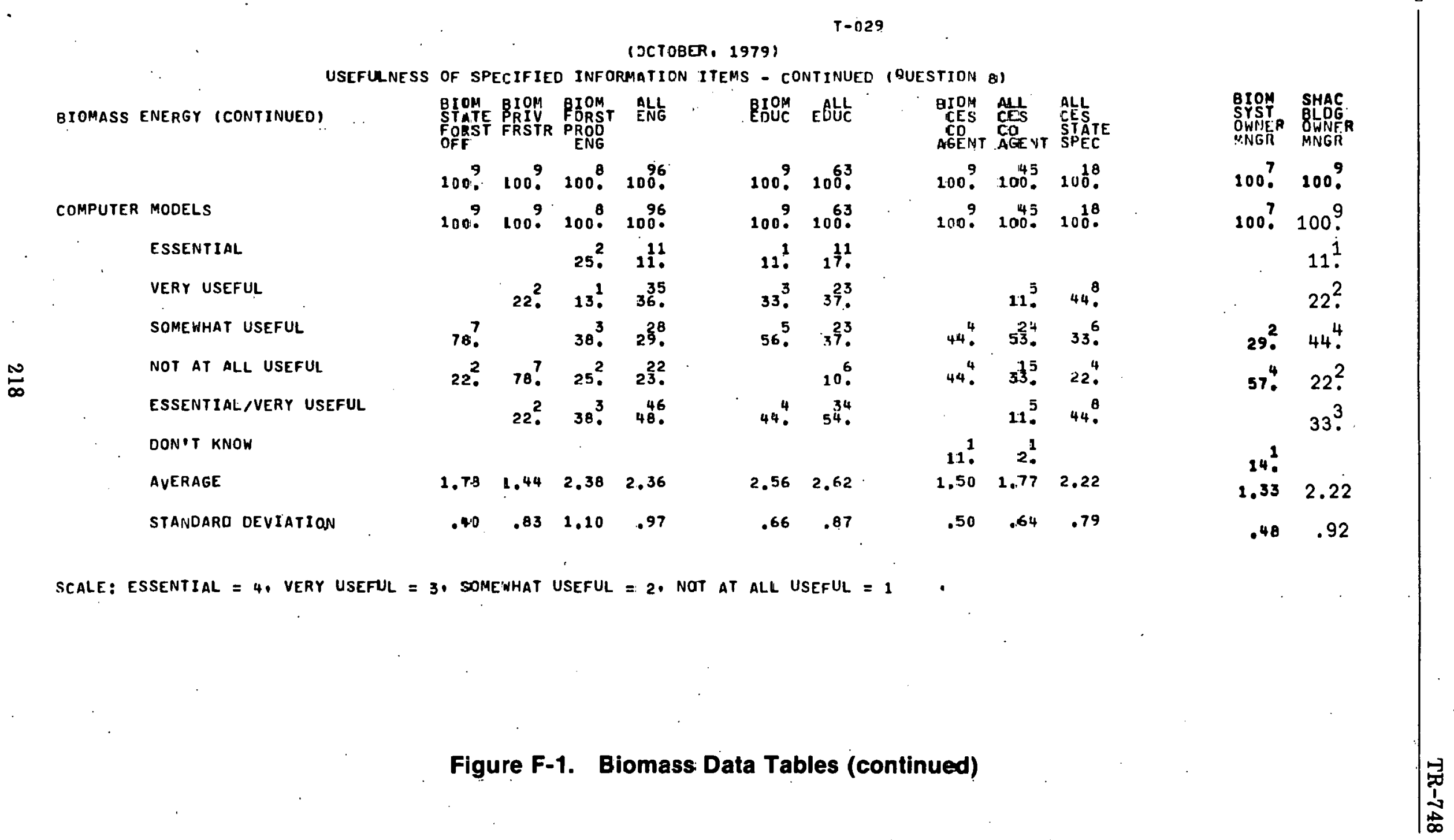


(OCTOBER, 1979$)$

USEFULNESS OF SPECIFIED INFORMATION ITEMS - CONTINUED (QUESTION B)

GoBNSt ITUPYCATI IONAL.

ESSENTIAL

VERY USEFUL

SOMEWHAT USEFUL

NOT AT ALL USEFUL

ESSENTIAL + VERY

DON'T KNOW

\section{AVERAGE}

STANDARD DEVIATIION

QBB12i RESEARCH IN PROGRESS ESSENTIAL

VERY USEFUL

SOMEWHAT USEFUL.

NOT AT ALL USEFIJL

ESSEENTIAL + VERT

DON'T KNOW

AVERAGE

STANDARO DEVIATION
BIOM BIOM BIOM BIOM TOTAL TOTAL TOIAL TOIAL TOTAL ALL RES CORES RES

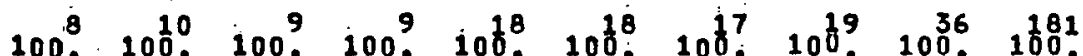

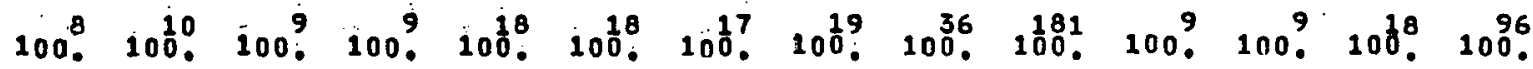
11. $\quad 6_{0}^{1} 6_{0}^{1} \quad 3_{0}^{1} 1_{0}^{1} 1_{1}^{1} \quad 6_{0}^{1} 8^{8}$

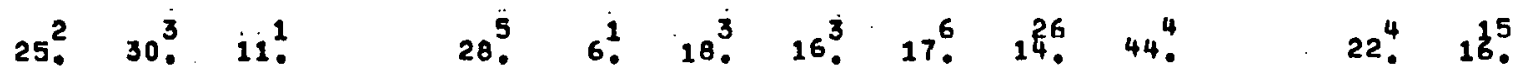

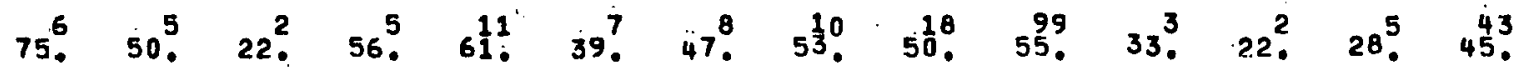

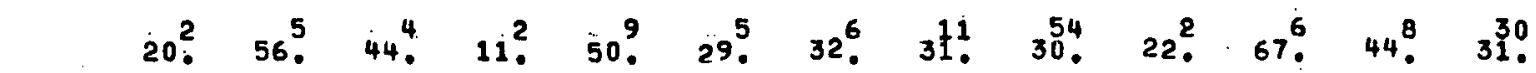

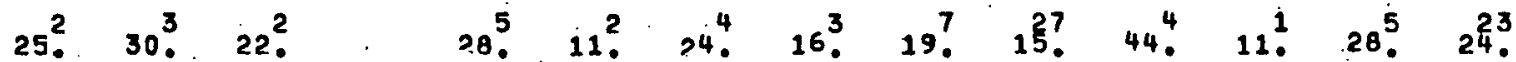
$\begin{array}{ll}1 & 1 .\end{array}$

$\begin{array}{llllllllllllll}2.25 & 2.10 & 1.78 & 1.56 & 2.17 & 1.67 & 2.00 & 1.84 & 1.92 & 1.86 & 2.22 & 1.56 & 1.89 & 2.01\end{array}$

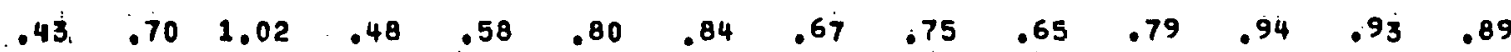

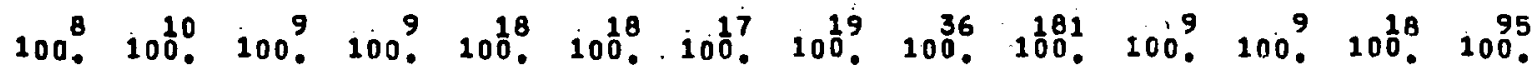

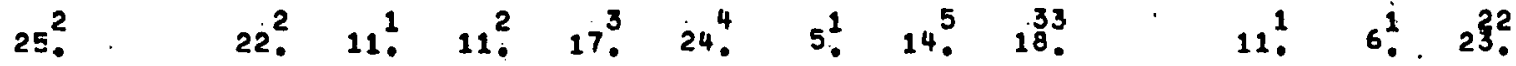

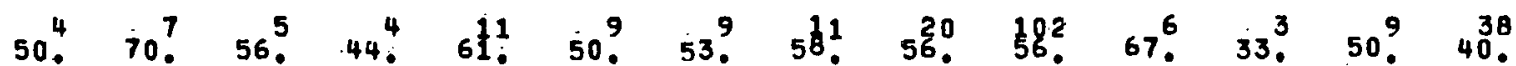

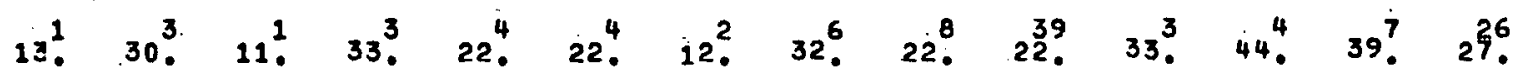

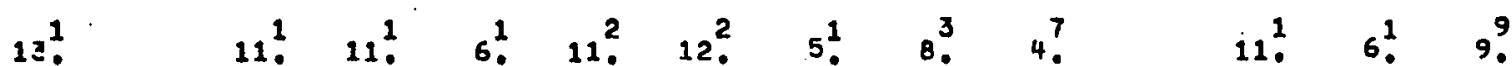

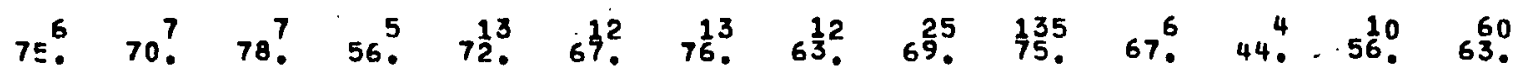

$\begin{array}{llllllllllllll}2.28 & 2.70 & 2.89 & 2.56 & 2.78 & 2.72 & 2.88 & 2.63 & 2.75 & 2.89 & 2.67 & 2.44 & 2.56 & 2.77\end{array}$ $\begin{array}{llllllllllllll}.51 & .45 & .87 & .81 & .70 & .87 & .90 & .67 & .79 & .73 & .45 & .84 & .66 & .90\end{array}$

SCALE: ESSENTIAL $=4$, VERY USEFUL $=3$, SOMEWHAT USEFUL $=2$, NOT AT ALL USEFUL $=1$

Figure F-1. Biomass Data Tables (continued) 
(OCTOBER, 19979 )

USEF JLNESS OF SPECIFIED INFORHATION ITEMS - CONTINUED (RUESTION Q)

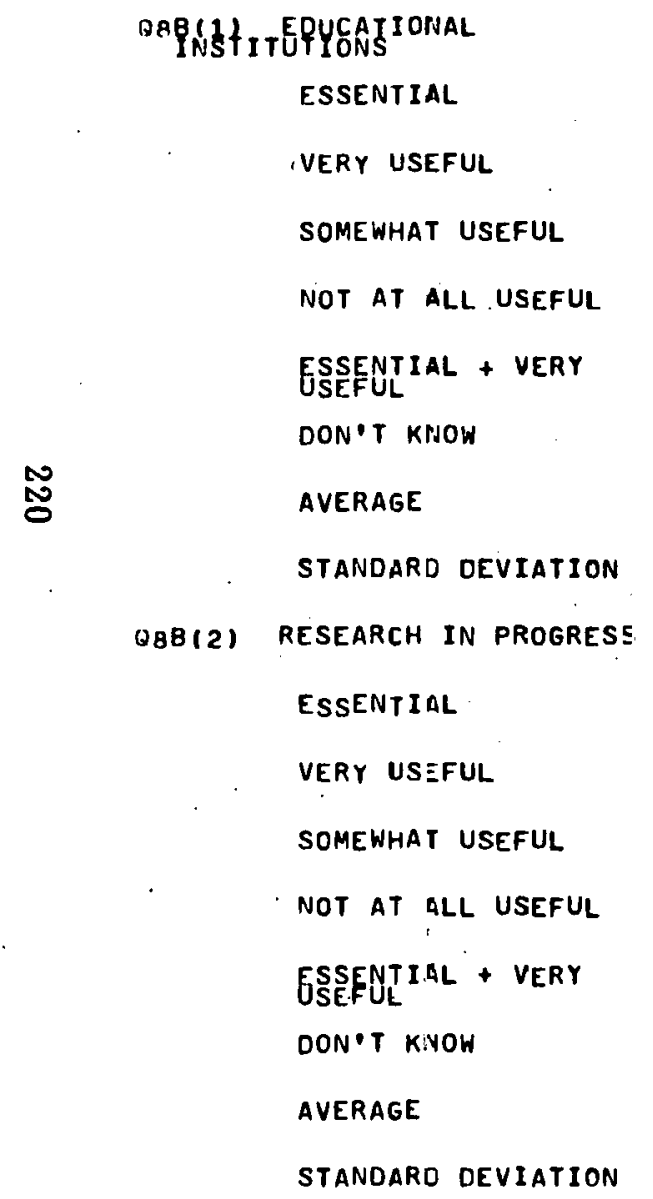

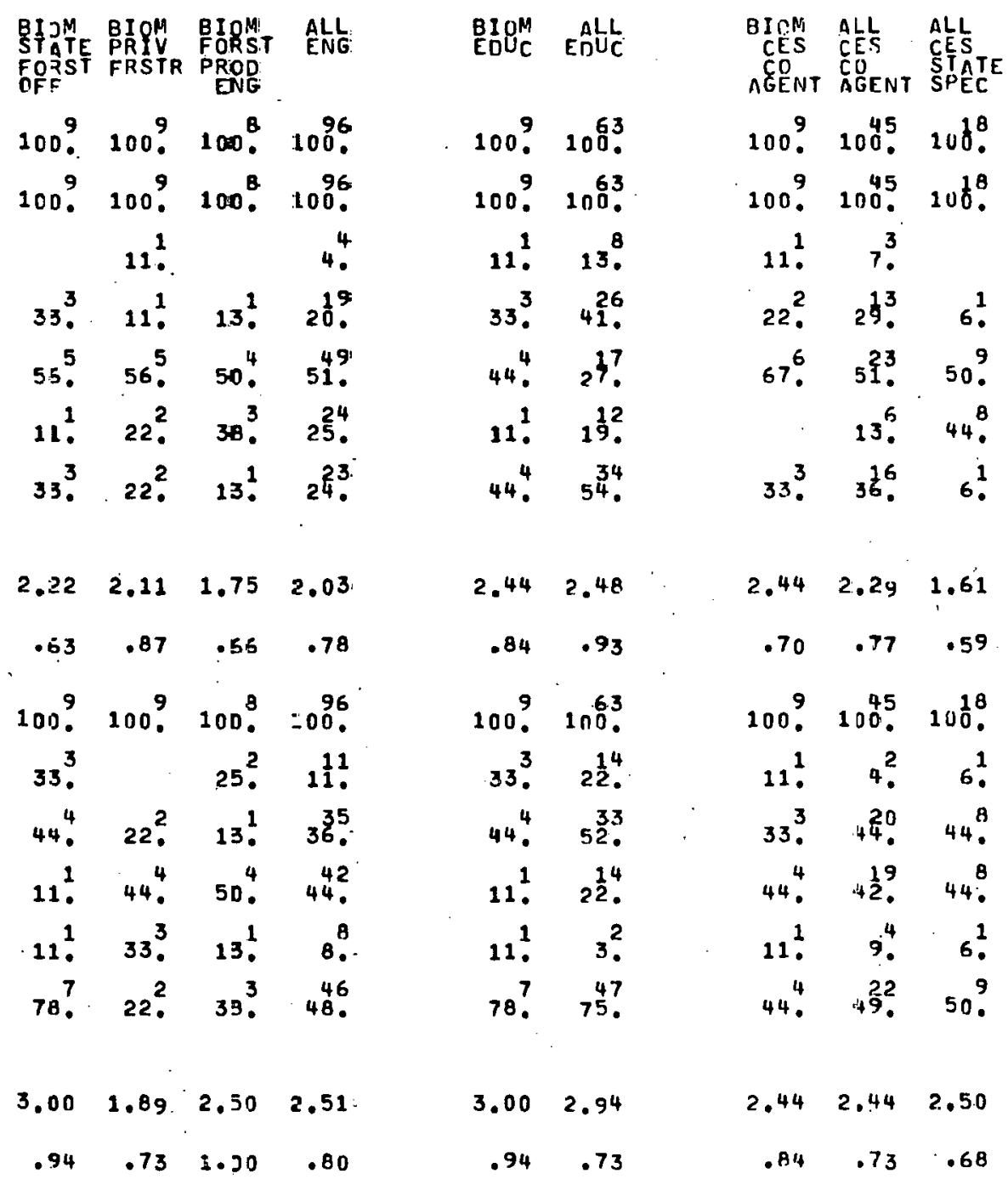

BIOMASS ENERGY (CONTINUEO) 
(OCTOBER, 1979)

USEFULNESS OF SPECIFIED INFORMATION ITEMS - CONTINUED (OUESTION Q)

BIOMASS ENERGY

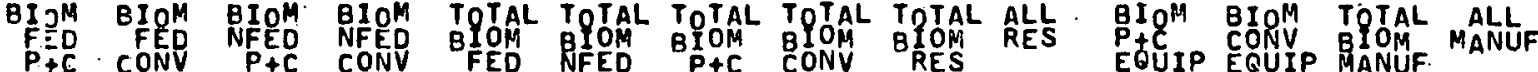

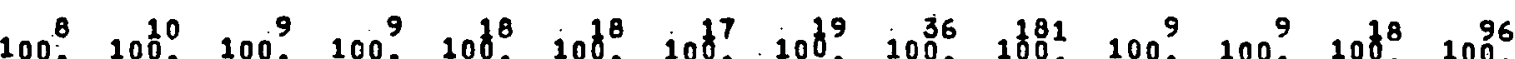

BBB(3) STATE OF ART

ESSENTIAL

VERY USEFUL

SOMEWHAT USEFUL

NOT AT ALL USEFUL

ESSENTIAL + VEAY

DON'T KNOW.

\section{AVERAGE}

STANDARD DEVIATION

100. 100. 100. 108. 10,. 10. 100. 100. 100. 100. 100. 100. 100.

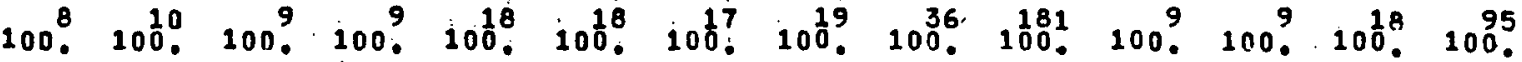

$3 B^{3} \cdot 10^{1} \quad 11^{1} \cdot 22^{2} \quad 22^{4} \quad 17^{3} \quad 24^{4} \quad 16^{3} \quad 19^{7} \quad 19^{3} \cdot 22^{2} \quad 33^{3} \quad 28^{5} \quad 24^{23}$

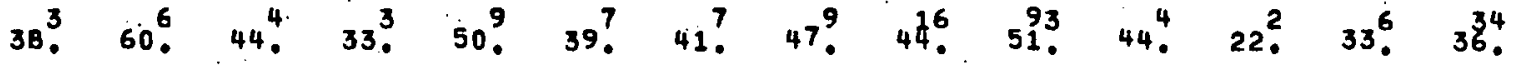

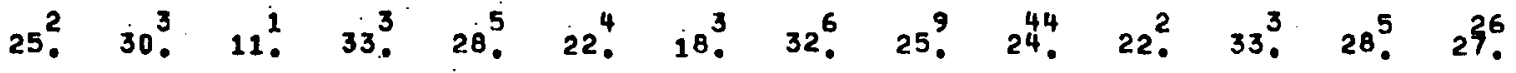

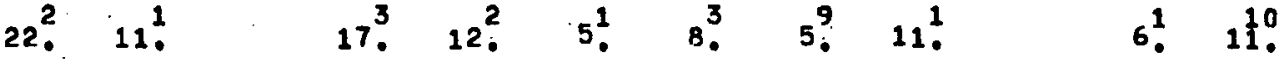

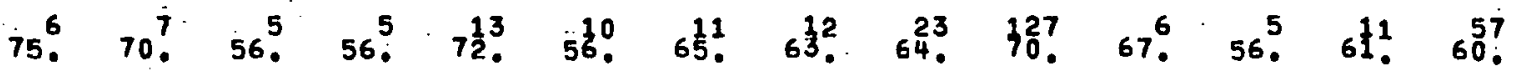

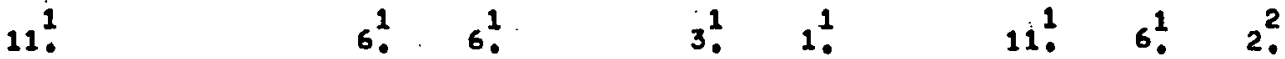

$\begin{array}{llllllllllllll}3.13 & 2.80 & 2.50 & 2.67 & 2.94 & 2.59 & 2.81 & 2.74 & 2.77 & 2.84 & 2.78 & 3.00 & 2.88 & 2.75\end{array}$

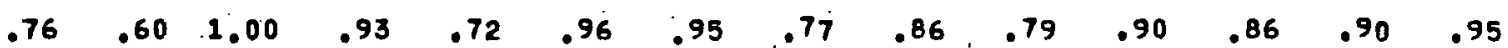

Q8B(4.) COSTSS/PERFGRMANCE

ESSENTIAL

VERY USEFUL

SOMEWHAT USEFUL.

NOT AT ALL USEFUL

USSEEUTIAL + VERY

DON'T KNOH

AVERAGE

STANDARD DEVIATION

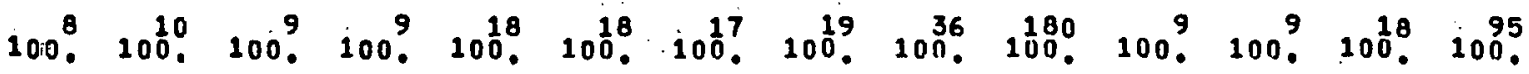

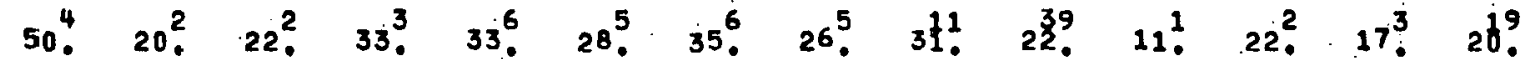

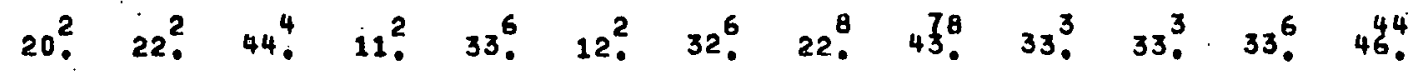

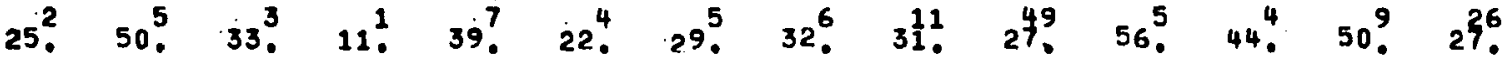

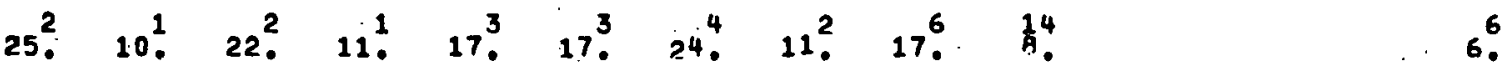

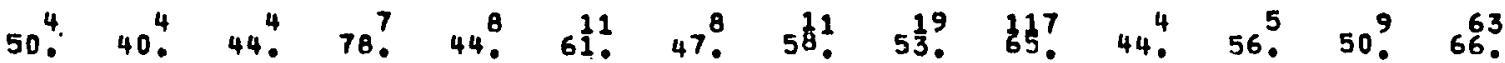

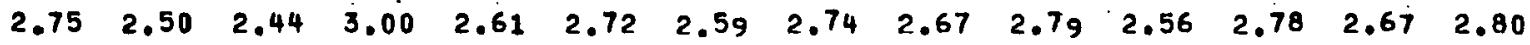

$\begin{array}{lllllllllllllll}1.29 & .92 & 1.07 & .94 & 1.11 & 1.04 & 1.18 & .95 & 1.07 & .86 & .66 & .77 & .73 & .82\end{array}$

SCALE: ESSENTIAL $=4$, VERY USEFUL $=3$, SOMEWHAT USEFUL $=2$, NOT AT ALL USEFUL $=1$

Figure F-1. Biomass Data Tables (continued) 
(OCTOBER, 1979 )

USEFULNES.S OF SPECIFIED INFJRMATION ITEMS - CONTINUED (NUESTION 3)

BIOMASS ENERGY (EONTINUED)

ESSENTIAL

VERY USEFUL

SOMEWHAT USEFUL

NOT AT GLL USEFUL

ESSENTIAL + VERY

DON'T KNOW

No

AVERAGE
STANDARD DEVIATION

QBB (4) COSTS/PERFORMANCE

\section{ESSENTIAL}

VERY USEFUL

SOMEWHAT USEFUL

NOT AT ALL USEFUL

ESSENTIAL + VERY

DON'T KNOW

AVERAGE

STANDARD DEVIATION

\begin{tabular}{|c|c|c|}
\hline $\begin{array}{l}\text { BIOM } \\
\text { SfATE } \\
\text { FORST } \\
\text { OFF }\end{array}$ & $\begin{array}{l}\text { BIUM } \\
\text { PRIV } \\
\text { FRSTR }\end{array}$ & $\begin{array}{l}\text { BI JM } \\
\text { FO TST } \\
\text { PR DD } \\
\text { ENG }\end{array}$ \\
\hline $1010^{9}$ & $100^{9}$ & $100^{8}$ \\
\hline 1009 & $100^{9}$ & $100^{8}$ \\
\hline $33^{3}$ & $22^{2}$ & 13 \\
\hline & $11^{1}$ & $53^{4}$. \\
\hline $11^{1}$ & $44^{\circ}$ & $3 a^{3}$ \\
\hline 11. & $22^{2}$. & \\
\hline & $33^{3}$ & 5 \\
\hline
\end{tabular}

$\begin{array}{llll}3.00 & 2.33 & 2.75 & 2.76\end{array}$

$.94 \quad 1.06 \quad .56 \quad .81$

$100^{9} 100^{9}, 103^{8}, 1006$

$22^{2} .33^{3} \quad 3.3^{3} .25^{4}$.

33. $33^{3}$. $6.5 . \quad 49$.

33. $33^{3} .221$

$11^{1}$ 4.

$56^{5}, 67^{6} \cdot 103^{8}, 74^{71}$.

$2.67 \quad 3.00^{\circ} \quad 3.38 \quad 2.95$

$.93 \quad .81 \quad .94 \quad .78$
BIOM EUC EUC

1009 . 1003

100 ? 1003

$22^{2} \cdot 2^{15}$.

$67^{6} \quad 565$

11. $11^{11}$.

$3^{2}$

$89^{8} 79^{\circ}$

3.113 .00

$.57 \quad .73$

$100^{9} .100^{63}$

$22^{2} .320$

$22^{2} .37^{3}$

56.320

44. 483

$2.67 \quad 3.00$

$.80 \quad .79$

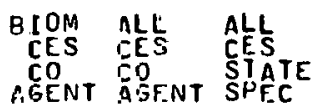

$100^{9} 10 \mathrm{~B}^{5}$. $100^{\circ}$

$100 \% 100^{5} \cdot 100^{10}$

$a^{1}$

33. $33^{15} .50$ ?

$56.56^{25} 50^{9}$.

112.94

$33^{3} .3^{16 .} 50^{9}$.

$2.22 \quad 2.29 \quad 2.50$

$.63 \quad .05 \quad .50$

$100^{9} 100^{4.5} 100^{18}$

$11^{1} 13^{6} \quad 11^{2}$

67. 7 . $^{6}$. $50^{9}$.

$22^{2}$ 11. $28^{5}$.

$11^{2}$

$78^{7} \quad 8^{40} \quad 6 \frac{11}{1}$

$2,89 \quad 3.02 \quad 2.61$

$.56 \quad .50 \quad .82$
BIOM SHAC

OWIIER QLDG

MNGR PNGR

100 ? 100 ?

100 ? 100 ?

$11^{1}$

43. $11^{3}$.

43. $44^{4}$.

$144^{2}-33^{3}$.

$43^{3} .22$.

2.292 .00

$.68 \quad .94$

100? 100 ?

$144^{2} 67$.

57. 22 ?

$29^{2}$.

11.

11. $89^{8}$.

$2.86 \quad 3.44$

$.62 \quad .96$

SCALE: ESSENTIAL $=4$, VERY USEFUL $=3$, SOMEWHAT USEFUL $=2$. NOT AT ALL USEFIL $=1$

Figure F-1. Biomass Data Tables (continued) 
(OCTOBER, 1979$)$

USEFULNESS OF SPECIFIED INFORMATION ITEMS - CONTINUED (QUESTION B)

BIOMASS ENERGY

QBB(5) COSTS INSTALL/OPERATE

ESSENTIAL

VERY USEFUL

SOMEWHAT USEFUL

NOT AT ALL USEFUi.

ESSENTI USEL + VERY

DON'T KNOW

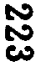

A.VERAGE

STANDARD DEVIATION

QBB(6) BUILDING CODES/REGS

ESSEN.TIAL

VERY USEFUL

SOMEWHAT USEFUL

NOT AT ALL USEFUL

ESSENTIIAL + VERY

DON?T KNOW

AVERAGE

STANOARD DEVIATION

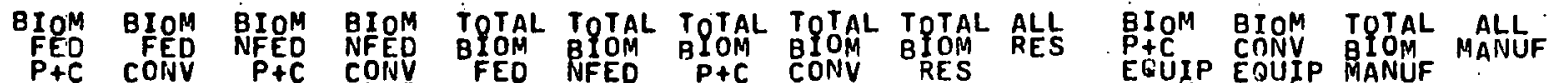
PES CONV P+C CON RES RES RES RES CONV

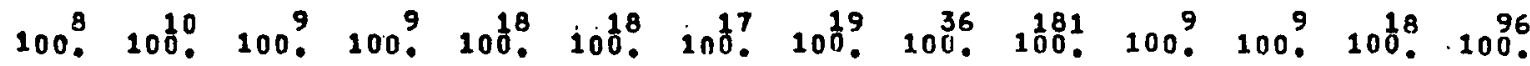

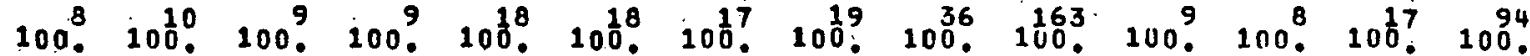

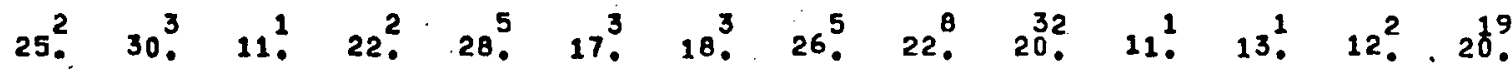

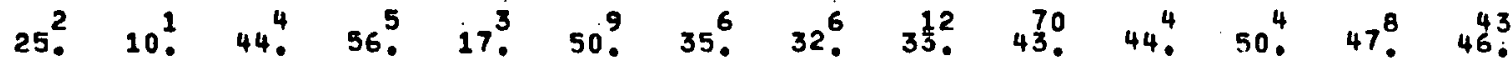

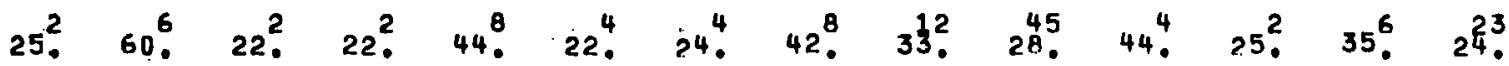

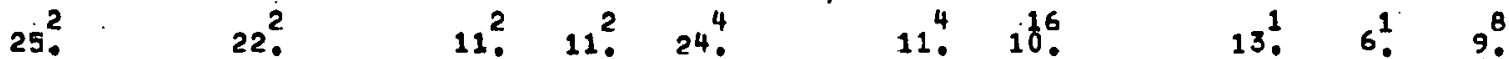

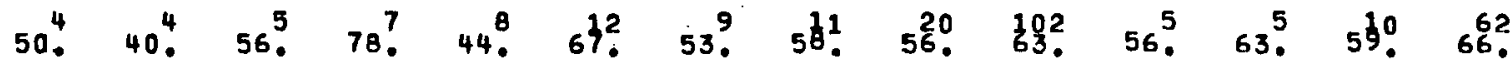

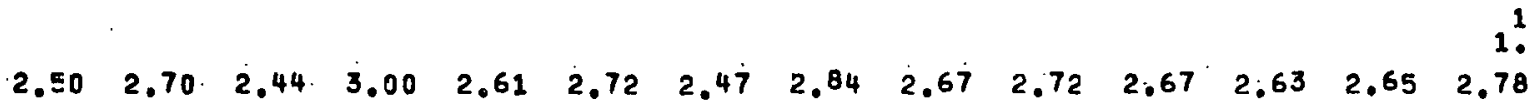
$\begin{array}{lllllllllllllll}1.11 & .90 & .96 & .66 & 1.01 & .87 & 1.03 & .81 & .93 & .90 & .65 & .84 & .75 & .88\end{array}$

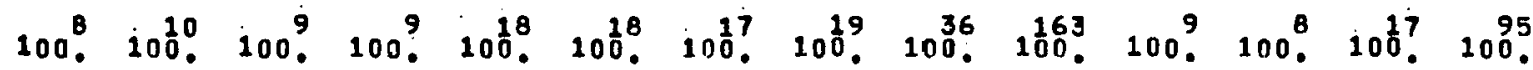

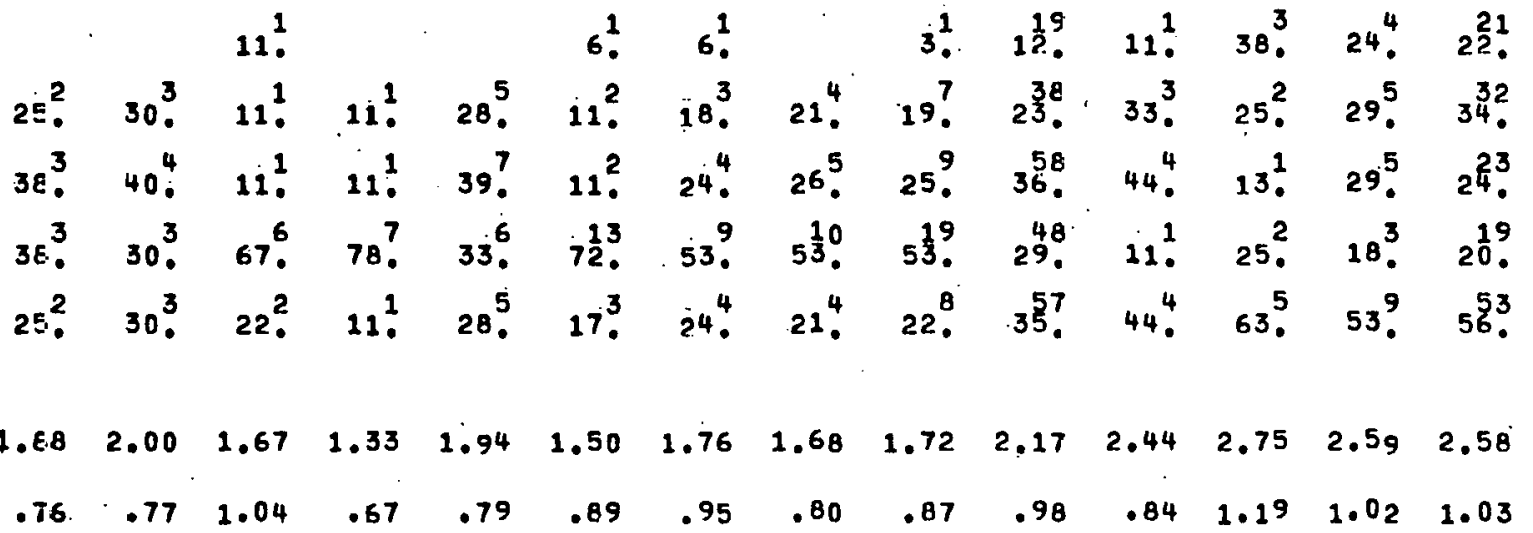

Figure.F-1. Biomass Data Tables (continued) 
IOCTOBER, 19791

USEFULNESS OF SPECIFIED ENFORMATION ITEMS - CONTINUED (NUESTION 8 I

BIOMASS ENERGY (CONTINUED)

ESSENTIAL

VERY USEFUL

SOMEWHAT USEFUL

NOT AT ALL USEFUL

ESSENTIAL + VERY

DON'T KNOW

$\mathbb{N}$

\section{AVERAGE}

STANDARO DEVIATIOM

QRB (6) BUILOING CODES/REGS

\section{ESSENTIAL}

VERY USEFUL

SOMEWHAT USEFUL

NOT AT ALL USEFUL

ESSENTIAL + VERY

DON'T K.NOW

AVERAGE

STANDARD DEVIATIOM

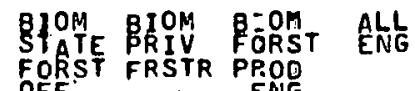

BIOM EOULC
\end{abstract}

$1000^{9} 100$. 100.1006

1009.1009 . 100. 1006 .

$22^{2} . \quad 33^{3} . \quad 38^{3} \cdot 23^{2}$.

44. $33^{3} .58^{3} .49^{4}$.

$22^{2}$. 22. $25^{2}$. $22^{21}$.

11 . 111 . 6 .

$6.7^{6} \quad 67^{6} \cdot 75^{6}$. $72^{69}$.

$\begin{array}{llll}2.78 & 2.89 & 3.15 & 2.89\end{array}$

$.90 \quad .99 \quad .76 \quad .81$

$1000^{9} \cdot 100^{9} \cdot 100^{6} \cdot 100^{96}$.

11 . $255^{2} \cdot 19$.

$44^{4} . \quad 25{ }^{2} \quad 25$.

$44^{4} .44^{4}, \quad 58.540$.

56. 1.3. 17.

$56.5250^{5}$. $44^{2}$.

$\begin{array}{llll}2.67 & 1.44 & 2.63 \quad 2.46\end{array}$

$\begin{array}{llll}.65 & .50 \quad .97 & .97\end{array}$
$1009.100^{63}$

$100^{9} .1003$

$22^{2}$. 30.

56. 4 ?

22. $16^{10}$.

B.

$78^{7} .76$.

$3.00 \quad 2.98$

.66 .89

$100^{9} .1063$

$22^{2} .10^{10}$

33. 35 ?

$22^{2} .320$

$22^{2} \cdot 1 \frac{11}{7}$.

56.532

$2.56 \quad 2.49$

$1.05 \quad .96$

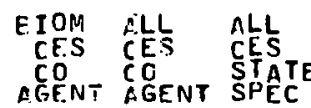

$100^{9} 100^{45} 100^{18}$.

$1009.400^{4} .100^{18}$

$11^{1} 18^{8} 11^{2}$

$78^{7}$. 73. $33^{6}$.

11. $9^{4}$. 39 .

$17^{3}$

$89^{8} .91^{41} \quad 44^{8}$.

$3.00 \quad 2.09 \quad 2.39$

$.47 \quad .50 \quad .88$

$100^{9} .100^{45} .100^{8}$.

11 . $9.411^{2}$

24. $22^{4}$.

56. $4 ?^{3} .611$.

33. $20^{3} .6{ }^{1}$.

$11^{1} 3^{15} .33^{6}$.

$1.89 \quad 2.22 \quad 2.39$

$.87 \quad .87 \quad .75$

100 ? 100 ?

$29^{2}$

29. $11^{1}$

$43^{3} .89^{8}$

SCALE: ESSENTIAL $=4$, VERY JSEFUL $=3$, SOMEWHAT USEFUL $=2$, NOT AT ALL USEFUL $=1$

Figure F-1. Biomass Data Tables (continued) 
(OCTOBER, 1979)

USEFULNESS OF SPECIFIED INFORMATION ITEMS - CONTINUED (QUESTION \&)

BIOMASS ENERGY

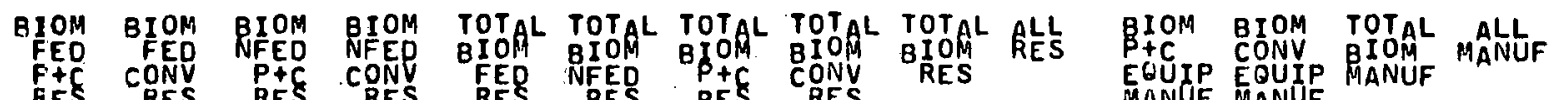

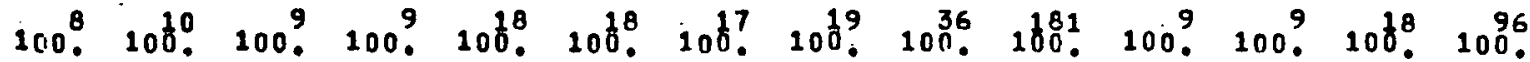

QBBITI TAX/ECONOMIC INCENTIVE ESSENTIAL

VERY USEFUL

SOMEWHAT USEFUL

NOt at ALL USEFUL

ESSEENTIIAL + VERY

DON'T KNOW

AVERAGE

STANDARD JEVIATION

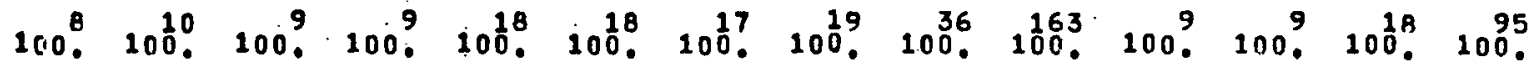

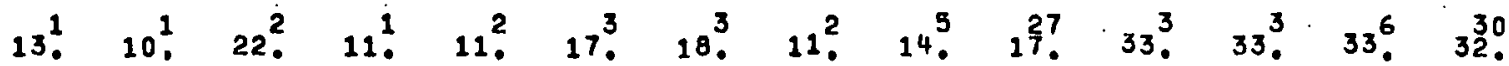

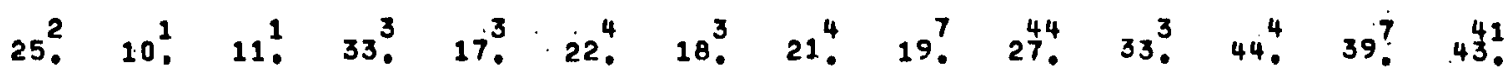

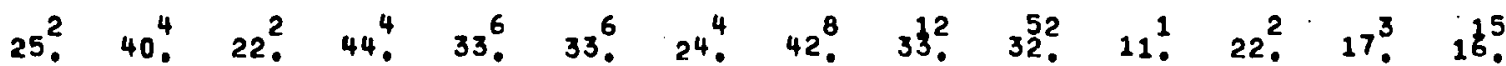

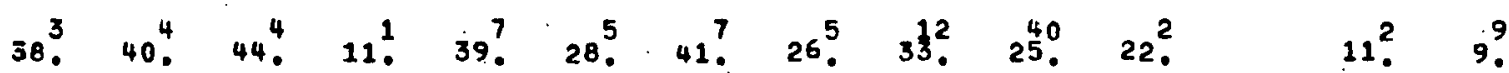
$38^{3} \cdot 20^{2} \cdot 33^{3} \cdot 44^{4} \cdot 28^{5} \cdot 39^{7} \cdot 35^{6} \quad 32^{6} \cdot 33^{2} \cdot 44^{7} \cdot 67^{6} \quad 78^{7} \cdot 72^{3} \cdot 75^{1}$.

$\begin{array}{llllllllllllll}2.13 & 1.90 & 2.11 & 2.44 & 2.00 & 2.28 & 2.12 & 2.16 & 2.14 & 2.36 & 2.78 & 3.11 & 2.94 & 2.97\end{array}$ $\begin{array}{llllllllllllll}1.04 & .94 & 1.19 & .84 & 1.00 & 1.03 & 1.12 & .92 & 1.02 & 1.01 & 1.12 & .74 & .98 & .91\end{array}$

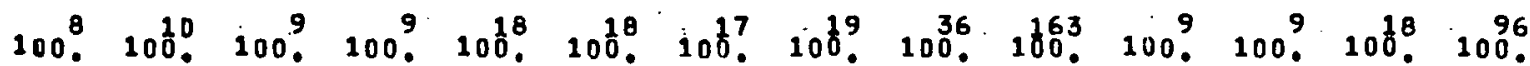

\section{ESSENTIAL}

VERY USEFUL

SOMEWHAT USEFLL

NOT AT ALL USÉFUL

ESSENTIIAL + VERY

DON P T KNOW

average

STANDARO DEVIATION

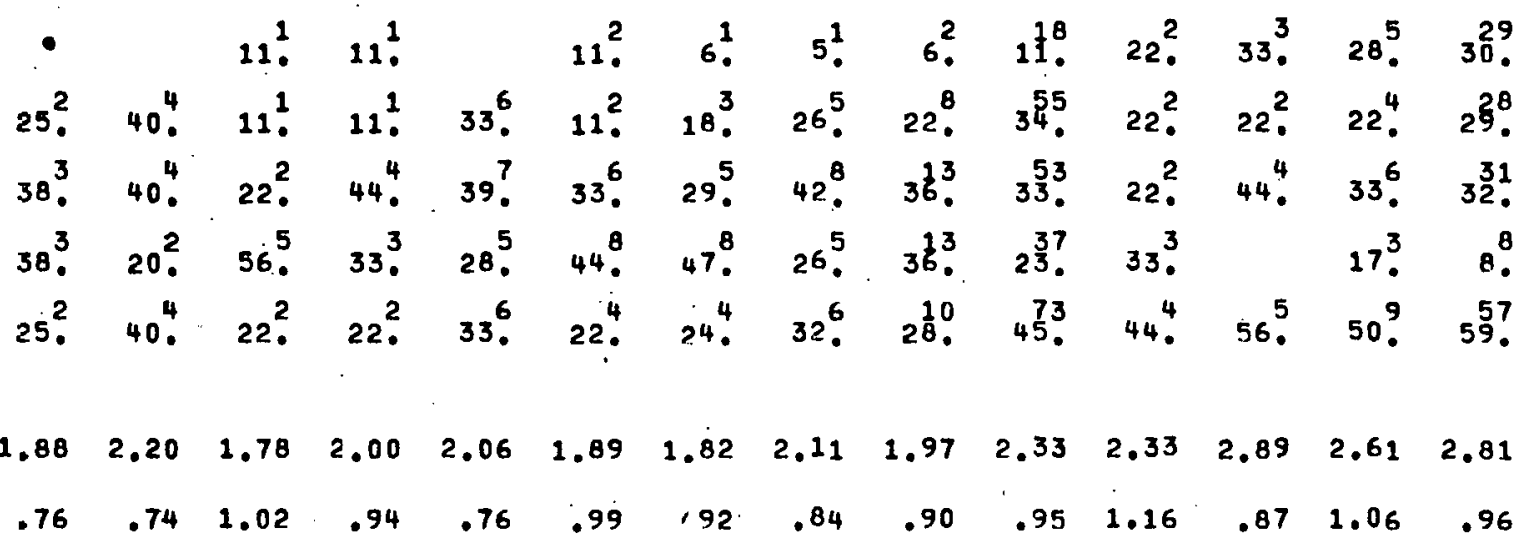




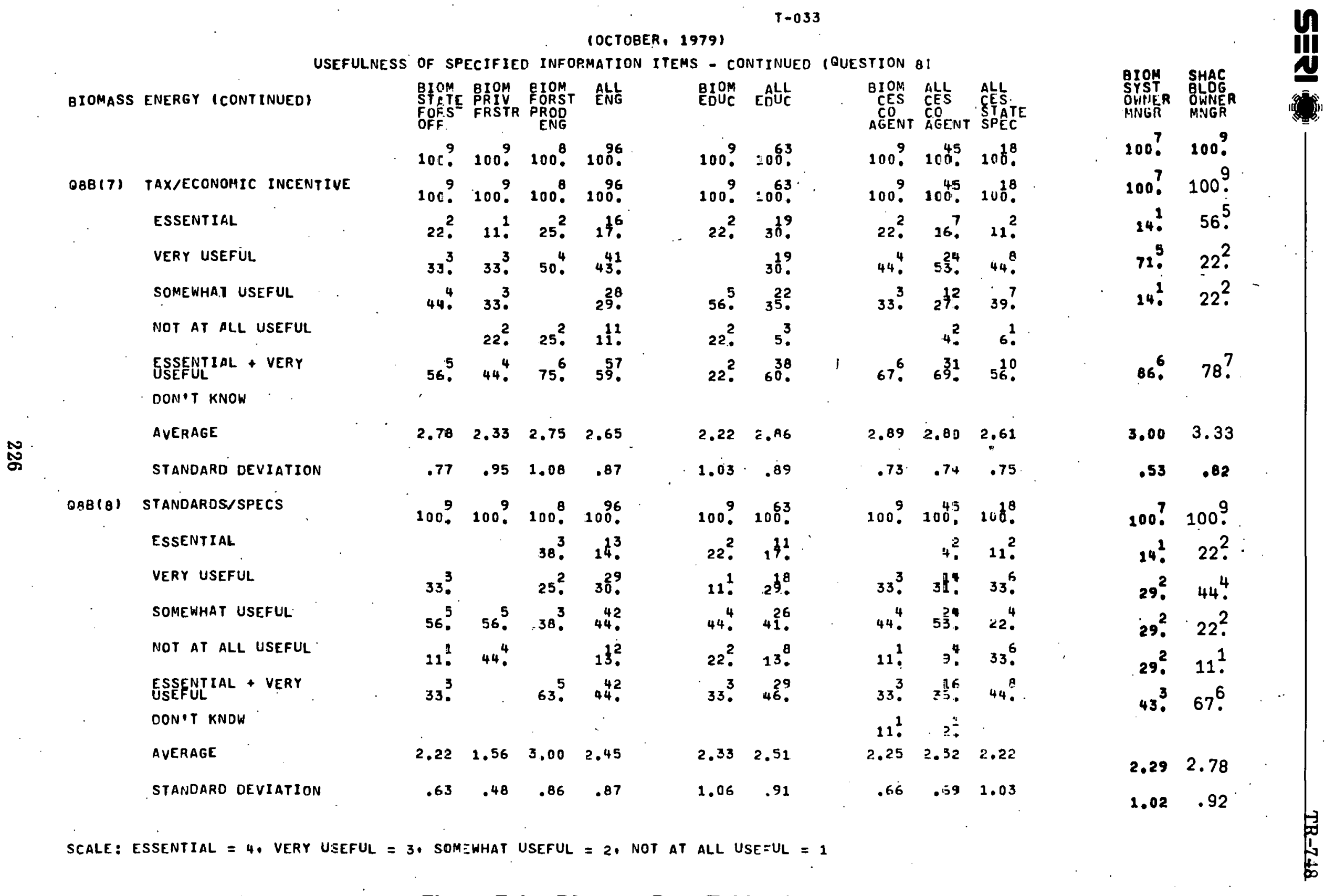

Figure F-1. Biomass Data Tables (continued) 
(OCTOBER, 1979$)$

USEFULNESS OF SPECIFIED INFORMATION ITEMS - CONTINUED (QUESTION Q)

BIONASS ENERGY

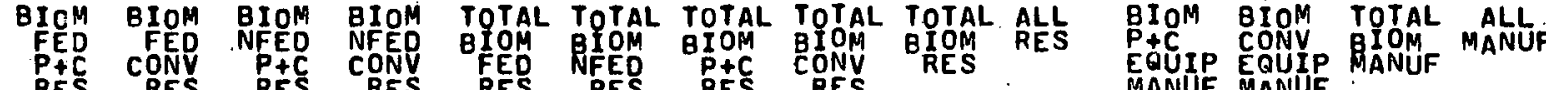
MANUF MANUF

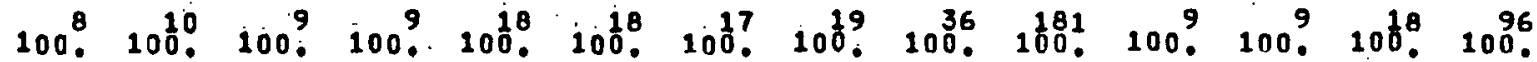

ORB(9) MARKETING/SALES DÄTA

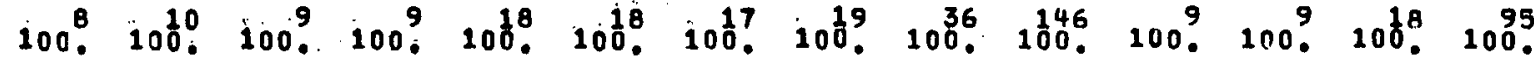
ESSENTIAL

VERY USEFUL:

SOMEWHAT USEFUL

NOT AT ALL USEFJL

ESSENTIIAL + VERT

DON T KNOW

AVERAGE

STANDARO DEVIATION

Q8B'101, OUTSIDE US RESEARCH/ ESSENTIAL

VERY USEFUL

SOMEWHAT USEFUL

NOT AT ALL USEFUL

USSEENTIAL + VERY

DON'T KNOW

Average

STANDARD DEVIATION

6. $6^{1}$.

$3: \quad 10^{14}$.

$25^{2} \quad 20_{0}^{2} \quad 44^{4} \quad 22^{4} \quad 22_{0}^{4} \quad 12^{2}, \quad 32_{0}^{6} \quad 22_{0}^{8} \quad 26_{0}^{38}$

$38^{3} \quad 40^{4}$

33. 11. 39. 22. 35. 26. 31. 38.

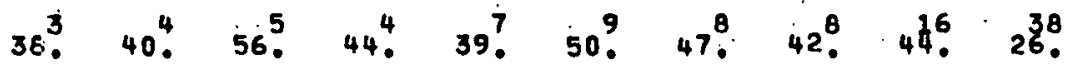

$25^{2} .20^{2}$

$\begin{array}{llllllllllllll}1.68 & 1.80 & 1.67 & 2.00 & 1.83 & 1.83 & 1.76 & 1.89 & 1.83 & 2.19 & 2.22 & 2.33 & 2.28 & 2.68\end{array}$

$\begin{array}{llllllllllllll}.76 & .74 & .93 & .94 & .77 & .96 & .88 & .86 & .87 & .93 & .92 & .82 & .86 & .94\end{array}$

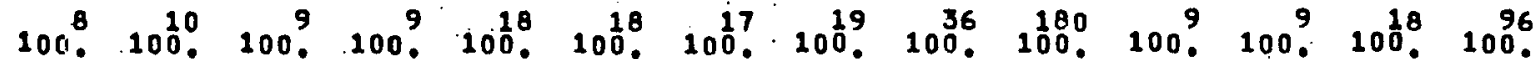

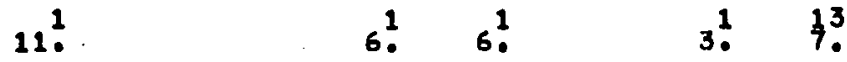

15.

$13^{1} \quad 200_{0}^{2} \quad 22_{0}^{2} \quad 22_{0}^{2} \quad 17_{0}^{3} \quad 22_{0}^{4} \quad 18_{0}^{3} \quad 21_{0}^{4} \quad 19^{7} \quad 28_{0}^{5} \quad 22^{2} \quad 11^{1} \quad 17_{0}^{3} \quad 26_{0}^{5}$

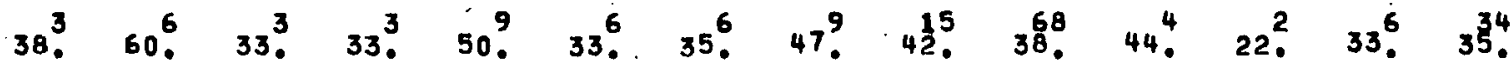

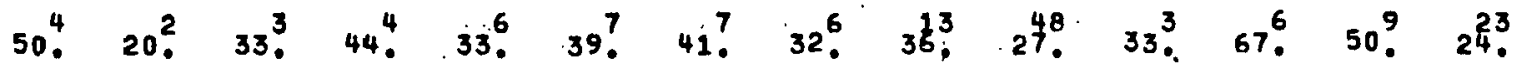

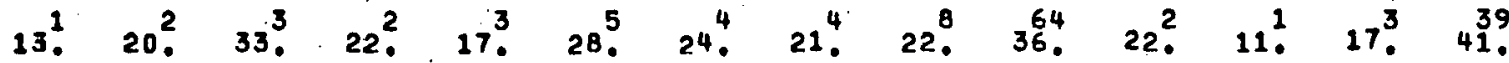

$\begin{array}{llllllllllllll}1.63 & 2.00 & 2.11 & 1.78 & 1.83 & 1.94 & 1.88 & 1.89 & 1.89 & 2.16 & 1.89 & 1.44 & 1.67 & 2.31\end{array}$

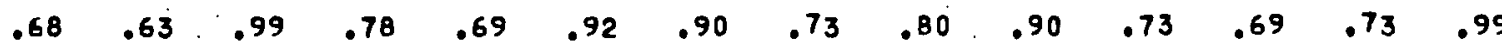


(OCTDBER, 2979$)$

USEFULNESS OF SPECIFIED INFORMATION ITEMS - CONTINUED (OUESTION B)

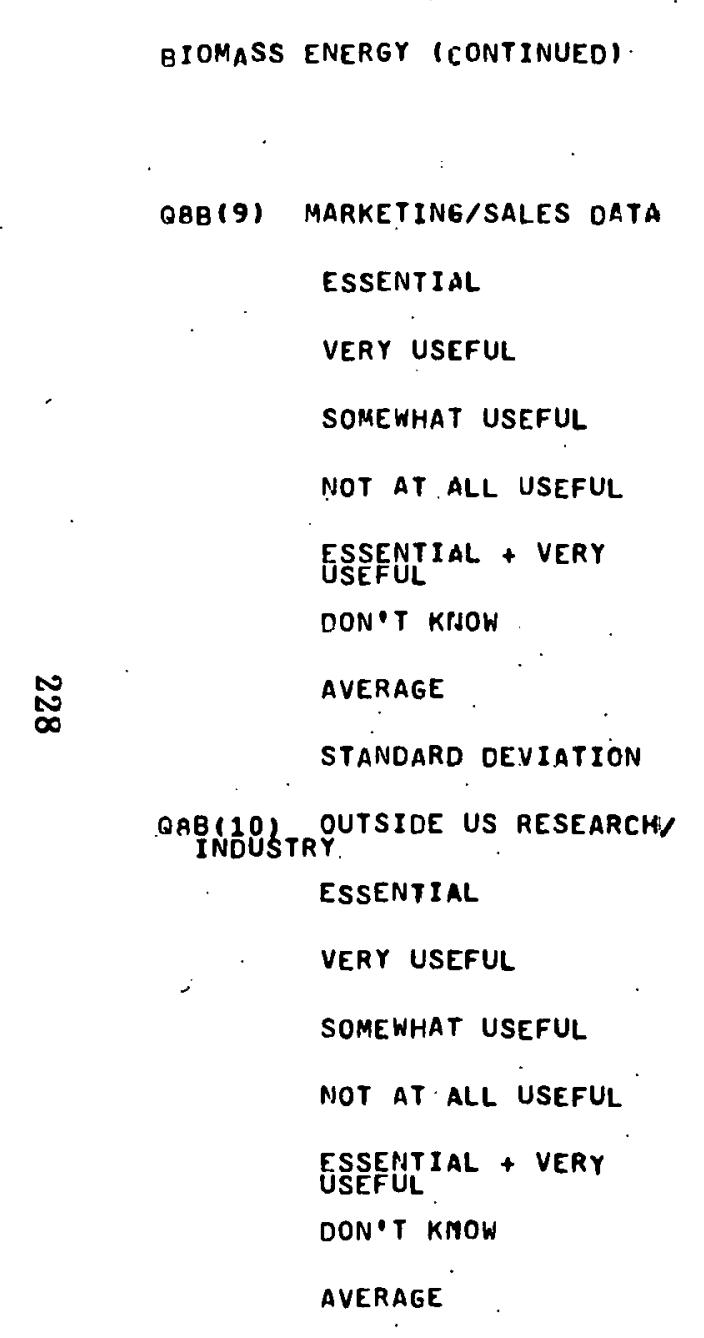

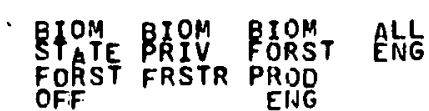

100 ? 100.1006

100 . 100.100

13. $43^{1}$

$35.325 .215^{3}$

$56^{5} \quad 63 . \quad 44^{34}$.

11.236.

$33^{3} . \quad 30^{3} \cdot 21^{16}$.

$\begin{array}{lll}2.22 & 2.50 & 1.88 \\ .63 & .70 & .82\end{array}$

$10 c^{9} 100$. $100.100 \%$

$11^{1} 13^{1} .5$

$25^{2} .11^{3}$.

$33^{3} \cdot 22^{2} \cdot 51^{4} \cdot 31^{30}$

67. $67^{6} .13^{1} .50^{48}$

11 . $3 s^{3} .19$.

$1.23 \quad 1.56 \quad 2.58 \quad 1.74$

$.48 .94^{\circ} .84 \quad .88$
BIOM EULC

$1009.100^{63}$

$100 \%$. 1003

8.

$33^{3} .24^{15}$

44. $41^{25}$.

$22.22^{17}$.

$33^{3} .320$.

$2.11 \quad 2.13$

$.74 \quad .89$

100. 1003

8.5

$11.2^{\frac{1}{2}}$.

$33^{3} . \quad 3^{23}$.

$56.52 \frac{21}{3}$

11. 30 .

$1.56 \quad 2.05$

$.67 \quad .9 ?$
BIOM ALL ALL
CES CCES CSES
CO CONT COATE
AGENT AGENT SY'EC

$100^{9} .100^{45} 100^{8}$.

$100^{\circ}$.

11 .

56.

$33^{3}$

11 .

1.78

. .62

${ }_{108}$ ?

6.

41 ?

53 .

6.

1.53

.60
O1OH SHAC

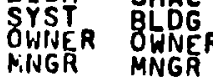

1.00 ? 100 ?

100 ? 100 ?

22 .

$29^{2} \cdot 11^{1}$

29. 22 .

$29^{2} .44^{4}$.

$29^{2}$. $33^{3}$.

14 ?

$2.00 \quad 2.11$

$.82 \quad 1.20$

STANDARD OEVIATIION

SCALE: ESSENTIAL $=4$, VERY USEFUL $=3$. SOMEWHAT USEFUL $=2$, NGT AT ALL USEFUL $=1$

Figure F-1. Biomass Data Tables (continued) 
(OCTOBER, 19791

USEFULINESS OF SPECIFIED INFORMATIION ITEMS - CONTINUED (QUESTION B)

BIOMASS ENERGY

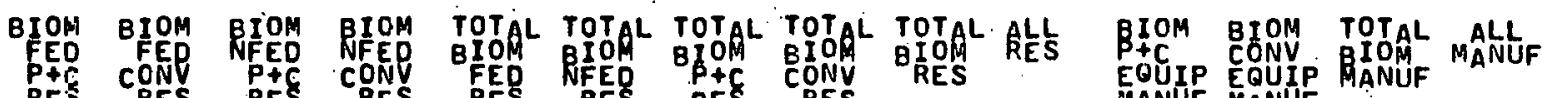

EOUIP EQUIP RANUF

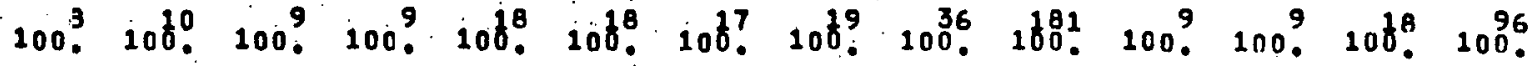

QBB(11). INFO ON MARKETING

ESSENTIAL

VERY USEFUL

SOMEWHAT USEFUL

NOT AT ALL USEFUL

ESSENTIAL + VERY

OON'T KNOW

AVERAGE

STANDARD DEVIATION $100^{9}$. 100 \% $100^{8 .} 100^{\circ}$. $22^{2} \cdot 11^{2} \cdot 23^{22}$ 22. $11^{2} \cdot 17^{3} \cdot 18^{17}$ $22^{2} \quad 33^{3} \quad 28^{5} \quad 35^{3}$. 56. $530^{3} \quad 44^{8} \cdot 24^{23}$ $22^{2} \cdot 33^{3} \quad 28^{5} \quad 41^{39}$

$1.67 \quad 2.22 \quad 1.94 \quad 2.40$

$\begin{array}{llll}.80 & 1.13 \quad 1.03 \quad 1.08\end{array}$

DBB(1Z) INST/SOCIAL/ENVIRON/

ESSENTIAL

VERY USEFUL

SOMEWHAT USEFUL

NOT AT ALL USEFUL

ESSENTIAL + VERT

DON P KNOW

AVERAGE

STANDARD DEVIATION

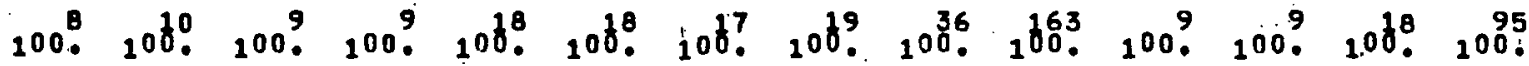
$25^{2}, 10_{0}^{1} \quad 11_{0}^{1} \quad 11_{0}^{1} \quad 17_{0}^{3} \quad 11_{0}^{2} \quad 18_{0}^{3} \quad 11^{2} \quad 14^{5} \quad b_{0}^{3} \quad 11_{0}^{1} \quad 11^{1} \quad 11_{0}^{2} \quad 9^{9}$

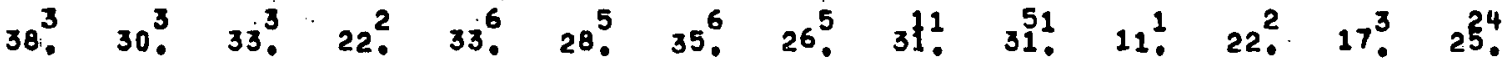

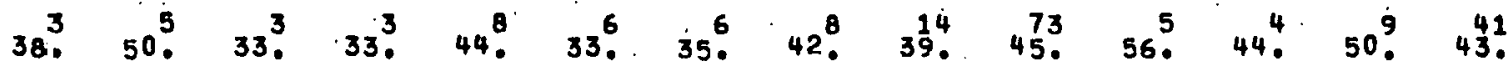

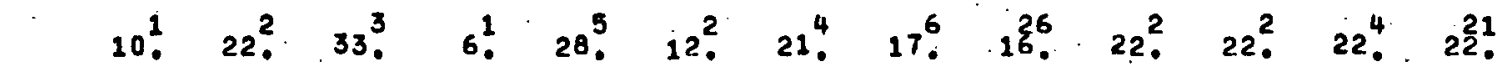

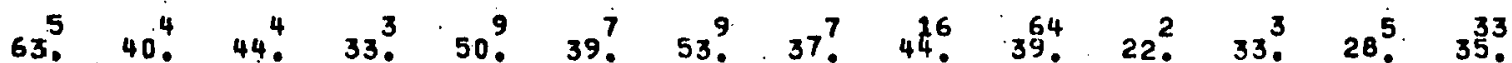

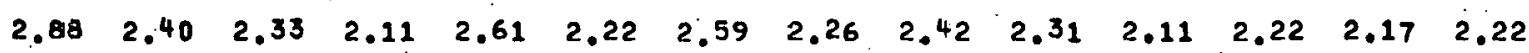

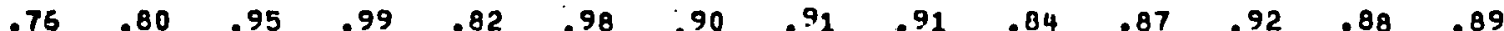

SCALE: ESSENTIAL $=4$, VERY USEFUL $=3$, SOMEWHAT USEFUL $=2$, NOT AT ALL USEFUL $=1$

Figure F-1. Biomass Data Tables (continued) 


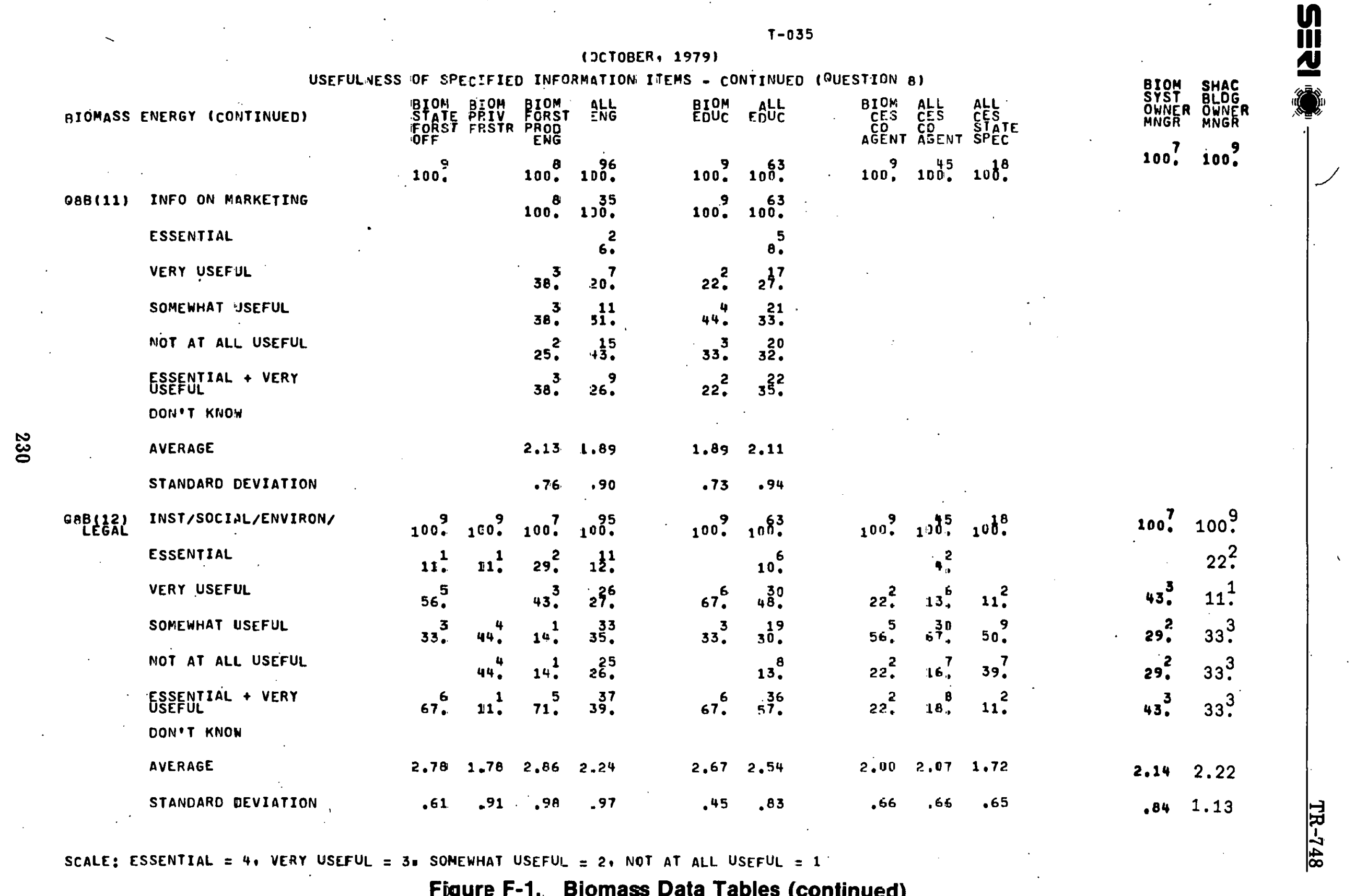

Figure F-1. Biomass Data Tables (continued) 
(OCTOBER, 19791

USEFULNESS OF SPECIFIED INFORMATION ITEMS - CONTINUED (QUESTION B)

BIOMASS ENERGY

BIOM BIOM BIOM BIOM TOTAL TOTAL TOTAL TOTAL TOTAL ALL

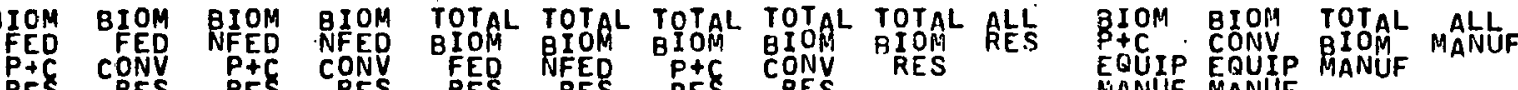

MIANUF MANUF

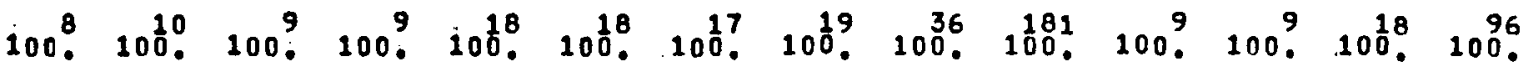

OBB(13) EXPECTEO DEVELOPMENTS

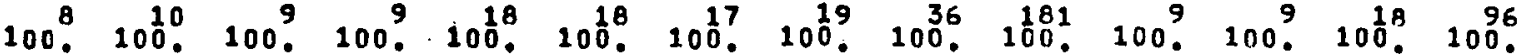

ESSENTIAL

VERY USEFUL

SOMEWHAT USEFUL

NOT AT ALL USEFUL

ESSENTIAL + VERY

DON'T KNOW

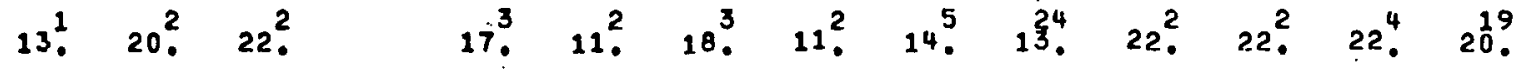

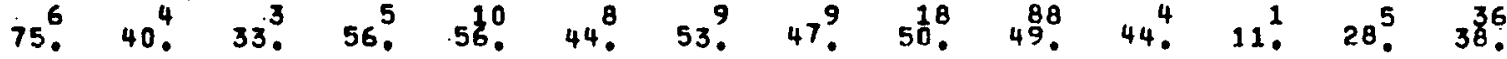

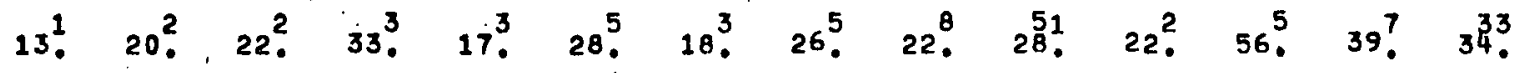

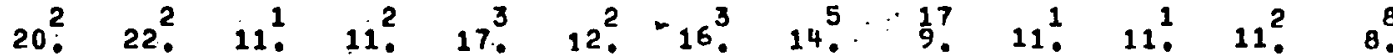

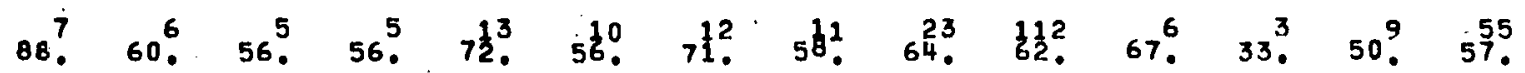

AVERAGE

STANDARO DEVIATION

Q8Bi1+1 CLIMATOLOGICAL DATA

ESSENTIAL

VERY USEFUL

SOMEWHAT USEFUL

NOT AT ALL USEFUL

ESSENTIAL + VEAY

DON'T KNOW

AVERAGE

STANDARD DEVIATION

\begin{tabular}{|c|c|c|c|c|c|c|c|c|c|c|c|c|c|}
\hline \multirow[b]{2}{*}{3.00} & \multirow[b]{2}{*}{2.60} & \multirow[b]{2}{*}{2.56} & \multirow[b]{2}{*}{2.44} & \multirow[b]{2}{*}{2.78} & \multirow[b]{2}{*}{2.50} & \multirow[b]{2}{*}{2.76} & \multicolumn{3}{|c|}{$1_{1}^{1}$} & \multirow[b]{2}{*}{2.78} & \multirow[b]{2}{*}{2.44} & \multirow[b]{2}{*}{2.61} & \multirow{2}{*}{2.69} \\
\hline & & & & & & & 2.53 & 2.64 & 2.66 & & & & \\
\hline .50 & 1.01 & 1.05 & .70 & .84 & .89 & .89 & .87 & .88 & .82 & .90 & .96 & .95 & .87 \\
\hline $100^{8}$ & $100^{10}$ & $100^{9}$. & $1000^{9}$ & $100^{18}$ & $100^{18}$ & $100^{17}$ & 100. & $\begin{array}{r}36 \\
100 .\end{array}$ & $\begin{array}{l}163 \\
100 .\end{array}$ & $100^{9}$ & $1000^{9}$ & $100^{18}$ & 1005 \\
\hline 13 ? & & $33^{3}$ & & $6 !$ & $17^{3}$ & $24^{4}$ & & $11^{4}$ & $21^{34}$ & $11^{1}$ & $22^{2}$ & $17^{3}$. & $29^{8}$. \\
\hline $25^{2}$ & $40^{4}$. & $11^{1}$. & $11^{1}$ & $33^{6}$. & $11^{2}$ & $10^{3}$ & $26^{5}$ & $22^{8}$ & 345 & $22^{2}$. & $11^{1}$ & $17^{3}$ & $29^{8}$. \\
\hline $25^{2}$. & $40^{4}$. & $22^{2}$. & $33^{3}$ & $33^{6}$. & $28^{5}$. & $24^{4}$ & $37 ?$ & $31^{1}$ & $\begin{array}{l}46 \\
28 .\end{array}$ & $44^{4}$. & & $22^{4}$. & $21^{20}$. \\
\hline $38^{3}$. & $20^{2}$. & $33^{3}$ & 56. & $28^{5}$ & $44^{8}$. & 35. & $37 ?$ & $3 b^{3}$ & $17^{8}$. & $22^{2}$ & 67. & $44^{8}$. & $20^{19}$ \\
\hline $38^{3}$ & $40^{4}$. & $44^{4}$. & 11 . & 39 ? & $28^{5}$. & 41. & $26^{5}$. & $33^{\frac{12}{3}}$ & $55^{89}$ & $33^{3}$. & $33^{3}$. & $33^{6}$. & 596 \\
\hline 3 & 20 & 2.44 & 1.56 & 2.17 & 2.00 & 2.29 & 1.89 & 2.08 & 58 & 2.22 & 1.89 & 2.06 & 2.68 \\
\hline & 74 & 1.26 & 67 & 98 & 10 & 18 & .79 & 01 & 1. & .92 & .28 & 1.12 & 1.10 \\
\hline
\end{tabular}

SCALE: ESSENTIAL $=4$, VERY USEFUL $=3$, SOMEWHAT USEFUL $=2$, NOT AT ALL USFFUL $=1$

Figure F-1. Biomass Data Tables (continued). 
IOCTIJBER, 19791

USEFULNESS OF SPECIFIED INFIRRATION ITEMS - CONTINUED IQUESTION .;:

BTOMASS EMERGY (CONTINUED)

ESSENTIAL

VERY USEFUL

SOMEWHAT USEFUL

NOT AT ALL USEFUL

ESSENTIAL + VERY

DON•T KVOW

心

\begin{tabular}{|c|c|c|c|c|c|}
\hline & AVERAGE. & 2.89 & 2.44 & 2.58 & 2.57 \\
\hline & STANDARD DEVIATION & .56 & .84 & .57 & .85 \\
\hline $08 B(24)$ & CLIMATOLOGICAL DATA & $100^{9}$ & $100^{9}$ & $10 \cdot 0^{B}$ & 1006 \\
\hline & ESSENTI.AL & 11 & $11^{1}$ & $1.5^{1}$ & 30 . \\
\hline & VERY USEFUL & $44^{4}$ & $22^{2}$ & $25^{2}$ & 40. \\
\hline & SOMEWHAT USEFUL & $22^{2}$ & $44^{4}$ & $53^{4}$ & 17. \\
\hline & NOT AT ALL USEFUL & $22^{2}$ & $22^{2}$ & $1.5^{1}$ & $14^{3}$ \\
\hline & ESSENTIAL + VERY & 56. & $33^{3}$ & $3: 3^{3}$ & $\begin{array}{l}67 \\
70\end{array}$ \\
\hline & DON'T KNOW & & & & \\
\hline & AVERAGE & 2.44 & 2.22 & 2.58 & 2.86 \\
\hline & STANDARD DEVIATION & .96 & .92 & .34 & 1.00 \\
\hline
\end{tabular}

BFOM BIOM BIJM ALL FCRST FRSTR PRDD

$100^{9} .100^{9} .103^{8} .100^{\circ}$

100 ? 100 ? $103^{8}, 100$.

11. $11^{1}$. $14^{13}$

$677^{6} \quad 33^{3} \cdot 53^{4}, 41^{39}$

$22^{2} \cdot 44^{4}, 33.35$.

11. $1.5^{1}$.10

$78^{7} \quad 44^{4} \quad 53^{4} \quad 54^{2}$

78. 44, 53, 54.

$\begin{array}{lllll}2.89 & 2.44 & 2.58 & 2.57\end{array}$
BIQM EDUC

$1009.100^{63}$.

$100.9100^{63}$

11. 27.

$33^{3} .49^{3}$.

$44^{4} .1 \frac{10}{16}$.

11. 6.

44.
46

2

$2.44 \quad 2.98$

$.84 \quad .84$

$1009.100^{63}$

44. $33^{2}$.

44. 38 .

2. 15

11. 53

$69^{\circ} 71^{45}$

$3.22 \quad 3.00$

.92 .87 $\begin{array}{cll}\text { EIOM } & \text { ALL } & \text { ALLL } \\ \text { CES } & \text { CLS } & \text { CESS } \\ \text { CO } & \text { CO } & \text { STATE } \\ \text { AGENT } & \text { HEENT SPEC S SPE }\end{array}$

$100^{9}=00^{45} \quad 108^{8}$

$100^{9}=0^{45} 100^{18}$

$11^{1} 4^{2} \quad 11^{2}$

$22^{2} \quad 51^{23} \quad 39^{7}$.

56. 31. 39 .

11. $13^{6} \quad 11^{2}$

33. $56^{25} .50^{9}$.

$2.33 \quad 2.47 \quad 2.50$

$.82 \quad .76 \quad .83$

$1.009 .200^{45} .106^{8}$.

$33^{3} . \quad 188^{8} \cdot 28$.

$33^{3} .51^{23} . \quad 39$ ?

$22.020^{2} .11^{2}$.

11 . $11^{5} .22$.

$677^{6} \quad 59.67^{3}$.

$2.89 \quad 2.76 \quad 2.72$

$.99 .85 \quad 1.10$
SIOM

BLDG MNGR MNGE

100? 100 ?

$100^{7} \cdot 100$ ?

$33^{3}$.

29. $11^{2}$.

$71^{5} 56^{5}$

29. $44^{4}$

2.292 .78

$.42 \quad .92$

$100^{7} \cdot 100^{9}$

$22^{2}$.

$22^{2}$

29. $56^{4}$.

7i. $11^{1}$

$44^{3}$

$1.29 \quad 2.56$

.43 .96

SCALE: ESSENTIAL $=4$, VERY LSEFUL $=3,{ }^{\circ}$ SOMEWHAT USEFUL $=2$, NOT AT ALL USEFUL $=1$

Figure F-1. Biomass Data Tables (continued) 


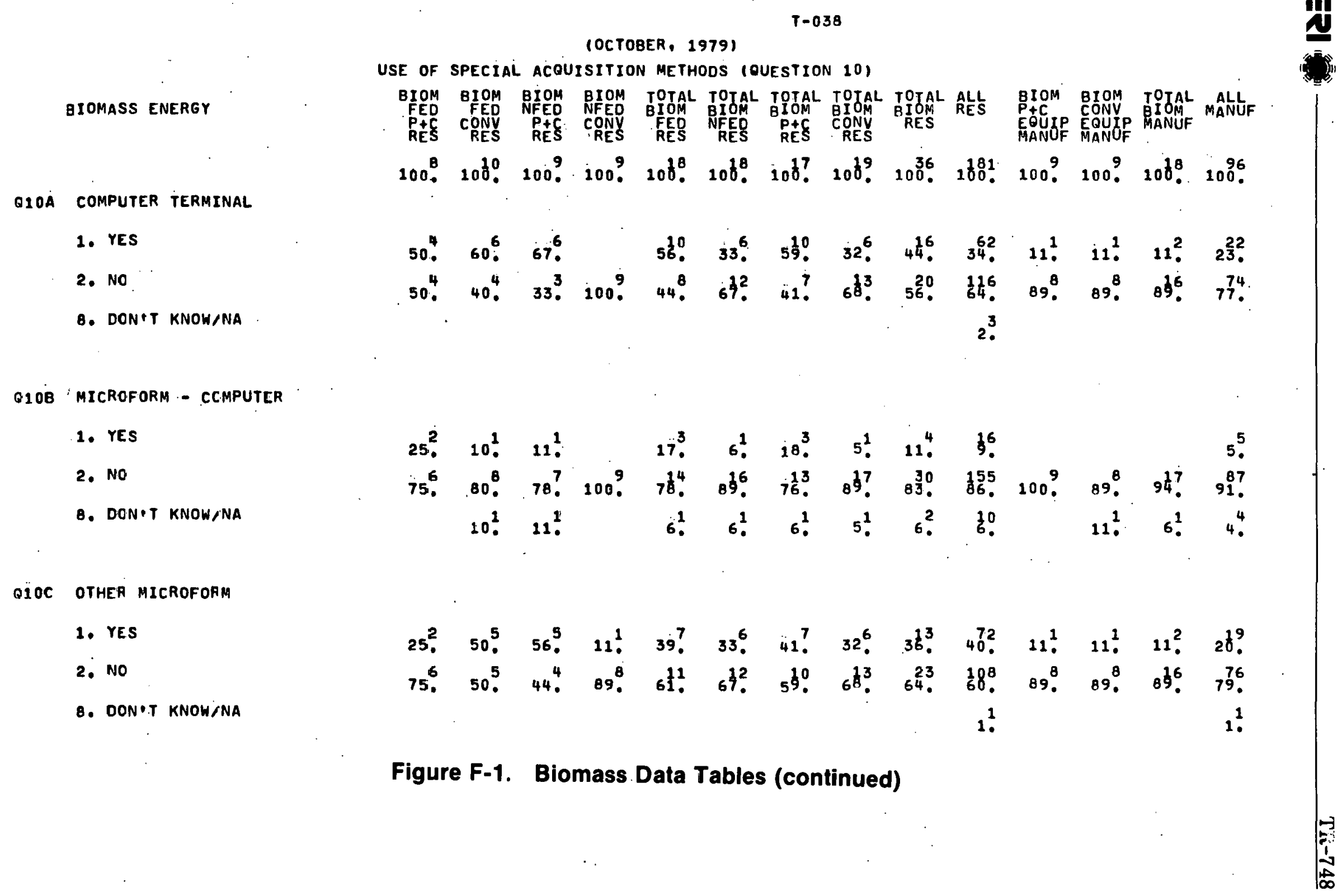


Figure F-1. Biomass Data Tables (continued)

BIOMASS ENERGY ICONT:NUED,

Q1OA COMPUTER TERMINAL
1. YES
2. NO
8. DONTT KNOW/RA

OIOB MICROFORM - COMPUTEP.
i. YES
2. NO
8. DON T KNOW/MA

Q10C OTHER MICROFJRM
1. YES
2. NO
8. DON T KNCH/NA

(OCTOBER, 1979)

USE OF SPECIA- ICQUISITION METHODS (QUESTION 10 )

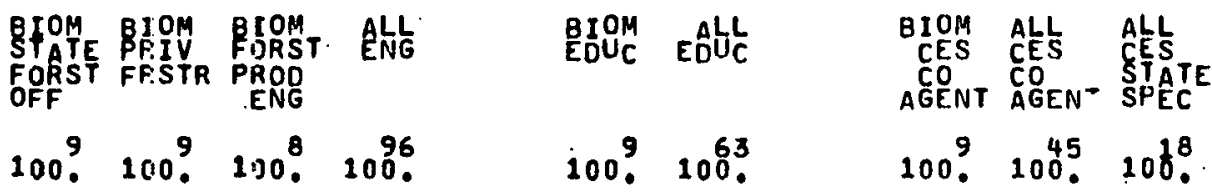

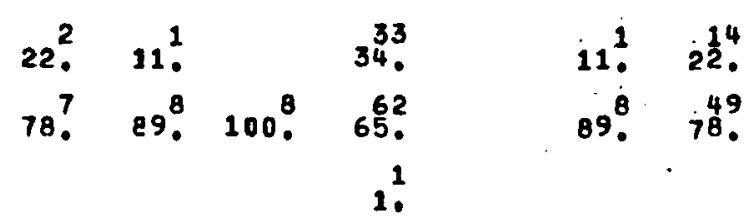

11. $15^{7} .44^{8}$

$89.84^{38} .56$.

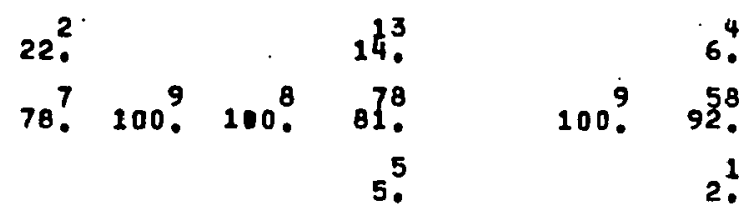

$\begin{array}{rrr}11^{1} & 7^{3} & 285^{5} \\ 89^{8} & 91^{4} \cdot & 61^{1} \\ & 2 ! & 11^{2}\end{array}$

44. $211^{1} \cdot 255^{2} \cdot 2^{25} \cdot$

56. 33 .

$11.93^{4} .6$.

44. 672 .

89. $91^{41} \quad 63^{2}$. 


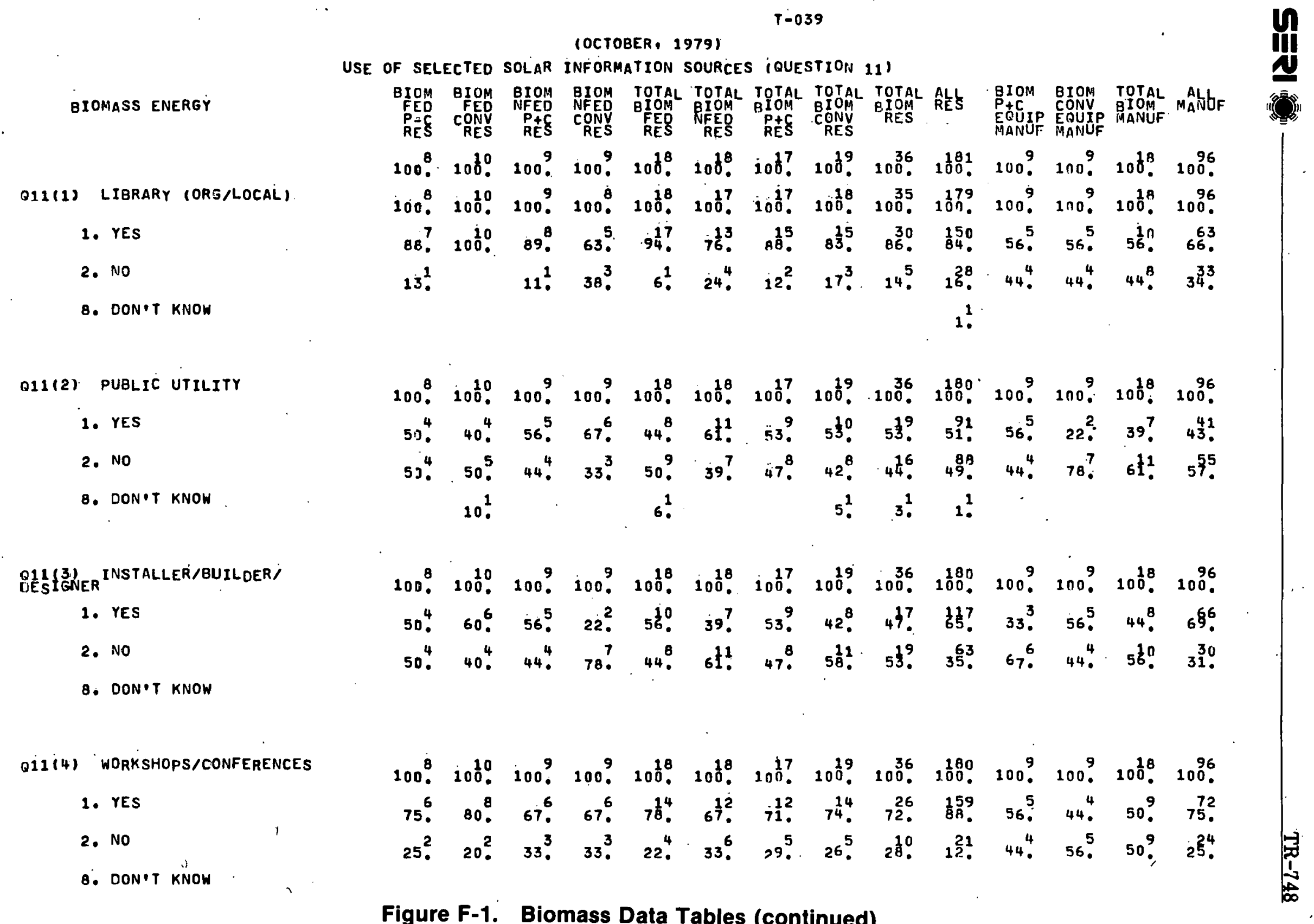




\section{$T-039$}

IOCTOBER, 1979)

USE OF SELECTED SOLAR IFIFORMA-ION SOURCES IOUESTION 111

BIOMASS ENERGY (CONTINUEO)

Q11(1) LIBRARY (ORG/LOCAL)
1. YES
2. NO
8. DON'T KNOW

011(2) PUBLIC UTILITY
1. YES
2. NO
B. DON'T KNOH

\section{OPI 13 I INER INSTALLER/EUILOER/}
1. YES
2. NO
8. DON'T KNOH

Q11(4) WORKSHOPS/CONFERENCES
1. YES
2. NO
8. DON'T KNOW

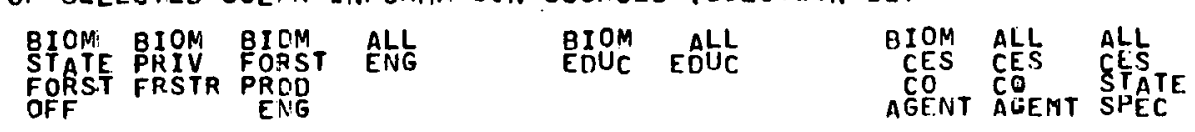

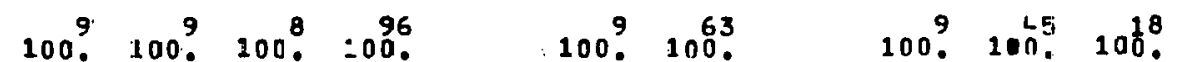

$100^{9} \quad 1000^{9} 100^{8}=00^{96} \quad 100^{9} .100^{63} \quad 100^{9} .100^{45} .100^{18}$

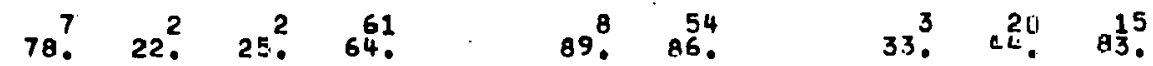

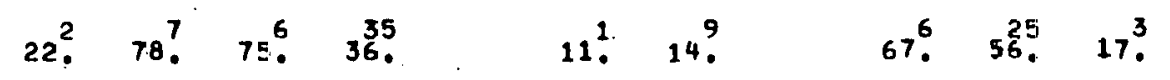

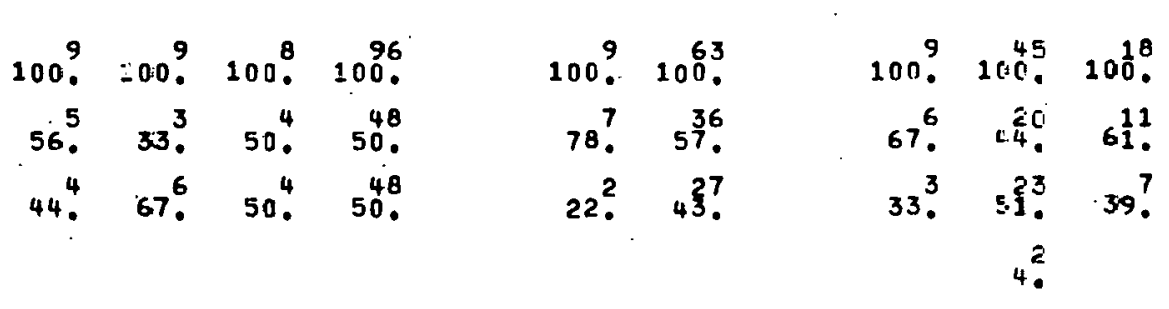

$100^{9} 100^{63} \cdot 100^{9} .1 c^{45} \cdot 10^{18}$.

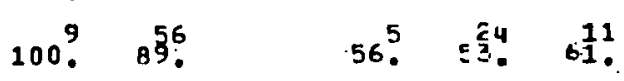

11? $44^{4}$. เ⿳⺈冂? 39 ?

33. 78 ? $25^{2} .14$.

\begin{abstract}
$100.2009 .200^{8}, 100^{96}$
$78.744^{4} .50^{4} . \quad 72$.

$22 . \quad 56.50 .428$.
\end{abstract}

$100^{9} \cdot 10^{63}$
$89^{8} .50^{5}$
$11^{1} \cdot 10^{6}$

$100.210^{45} \cdot 1077^{8}$.

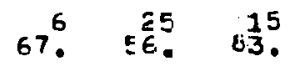

33. $43^{3} \div \quad 17$.

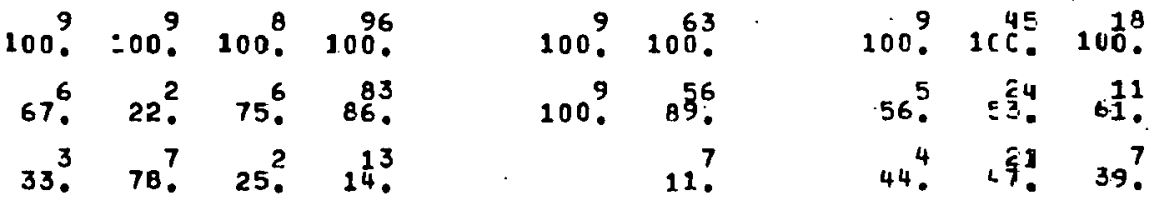

$100 ? 100$ ?

43. $70^{3}$ ?

57. $22^{2}$.

100 ? 100 ?

$06^{6}$. 100 ?

$14^{1}$.

$\begin{array}{rr}100 ? & 1009 \\ 06 . & 56 ! \\ 14 !^{6} & 33 ! \\ & 11 !^{3}\end{array}$

Figure F-1. Biomass Data Tables (continued) 
(OCTOBER, 1979 )

USE OF SELECTED SOLAR INFORMATION SOURCES - CONTINUED (QUESTION 11 )

BIOMASS ENERGY

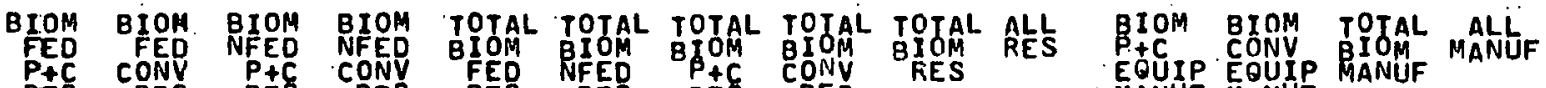

RES RES RES RES RES RES RES

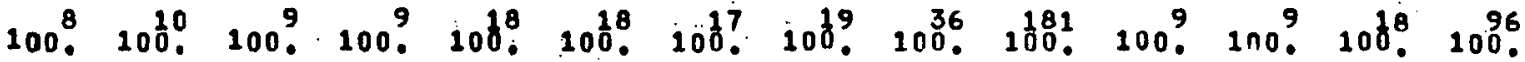

Q11(5) COMMERCIAL DATA BASE

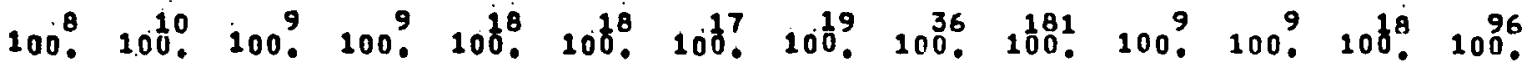

1. YES

2. NO

8. DON?T KNOH

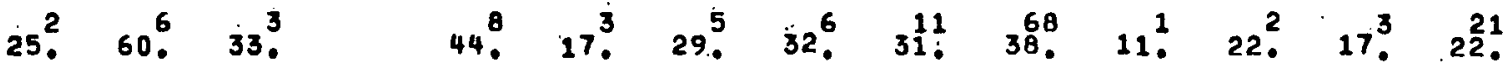

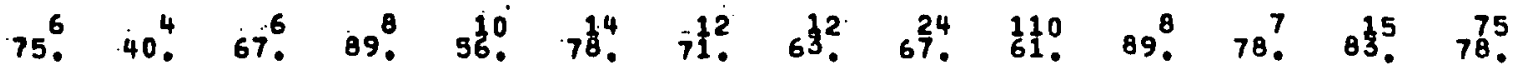

11. $\quad 6_{0}^{1} \quad 5_{0}^{1} \quad 3_{0}^{1} \quad 2^{3}$.

N

i. YES

2. NO

8. DONPT KNOH

QII(T) SSIE - SMITHSONIAN

i. TES

2. NO

8. DONPT KNOH

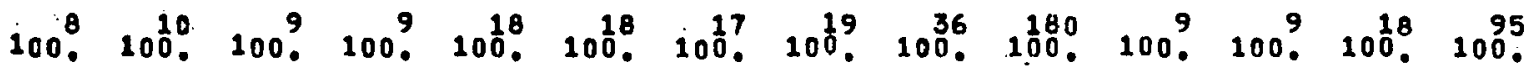

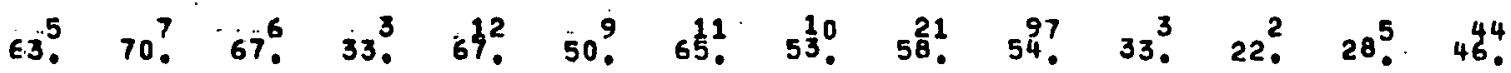

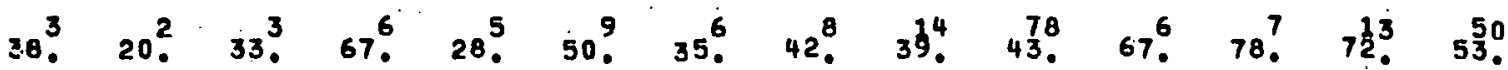

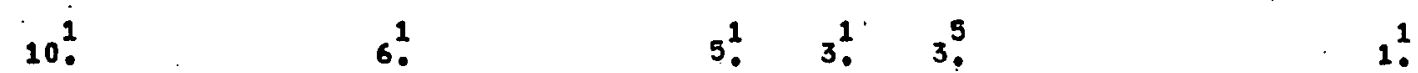

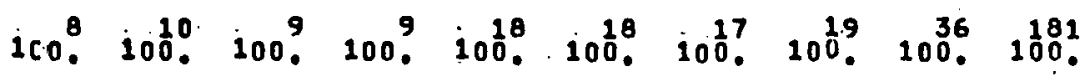

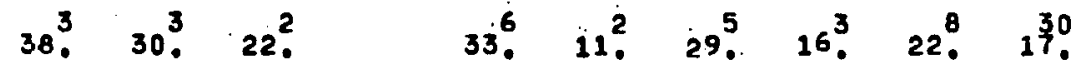

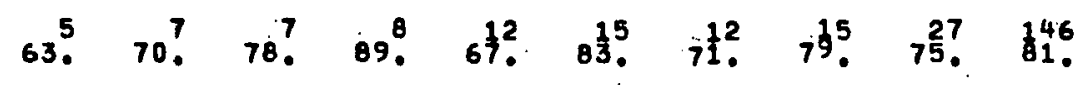

11. ${ }^{1}$ 6. $\quad 5_{0}^{1} \quad 3_{0}^{2} \quad 3^{5}$

Figure F-1. Biomass Data Tables (continued) 
:OCTOBER, 1979)

USE DF SELECTED SOLAR INFORYATION SOURCES - CONTINUED IQUESTION 210

BIOMASS ENERGY (CONTINUEO)

Q11(5) COMMERCIAL DATA BAEE

1. YES

2. NO

8. DON?T KNOW
FCRST FRSTR PROD

$100^{9}$. 100 ? $100 \% \div 00^{8}$.

$1009.100 \% 100^{8} .005$

$11^{1} \quad 11^{1}$ 13: $24^{23}$.

$787.89^{8} .75^{6}, 74^{70}$.

$11^{1}$ 13. $2^{2}$.

$1009.1009 .100 \% 1096$

$56^{5} \quad 56^{5}, 25.246^{2}$.

44. $44^{4} .75^{6} .52$.

$2^{2}$

B. DON'T KNOW

P11(7) SSIE - SHITHSONIAN

1. YES

2. NO

6. DON?T KNOW
BIDM BIOM BIOM ALL
EIOM EÂUC

1009.1003

1009.1003

$11^{1} .27$.

89.736

$100^{9} .100$.

56.52.

44. 48 ?

$100^{9} \cdot 130.5100^{18}$.

$56.33^{5} \cdot 6 ?^{2}$.

$44^{4}$. 50. $33^{6}$

$100^{9} .100$.

$17^{3}$

$1009.7 \frac{14}{8}$.

6.
BIOH SHAC

SYST BLDG

OWIER OWNER

$100^{7} 100$ ?

$100^{7} 100^{\circ}$.

$14^{1} .11^{2}$.

86. 89.8

$100 ?$. 100 ?

$29^{2} \quad 22^{2}$.

71.78 ?

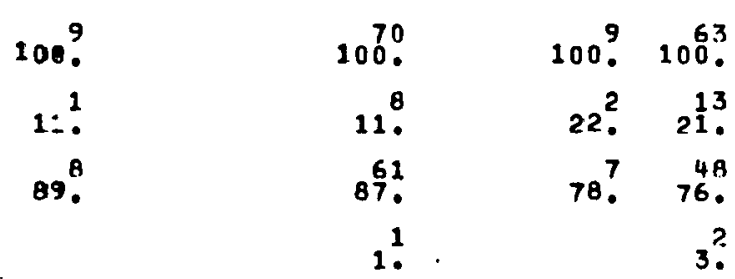

Figure F-1. Biomass Data Tables (continued)
100 ? 100 ?

29.

71. 100 . 
(OCTOBER, 1979)

USE OF SELECTED SOLAR INFORMATION SOURCES - CONTINUED (QUESTION 11)

BIOMASS ENERGY

Q1 GPC GOVPT PRINTING OFFICE-
1. YES
2. NO
B. DON T KNOW

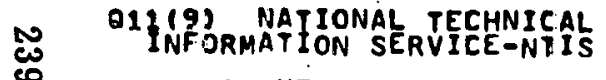
1. YES
2. NO
8. DON!T KNOW

O11 CEAPER IECHNICAL INFORMATION

1. YES

2. ND

B. DON T KNOH

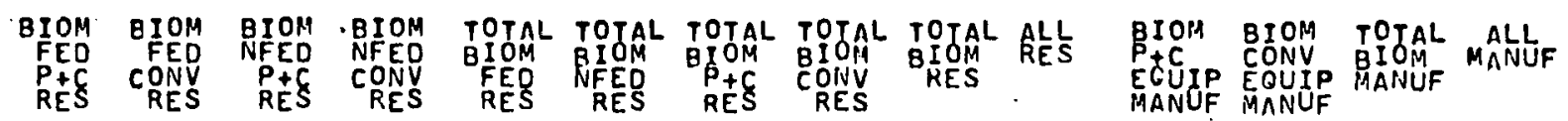

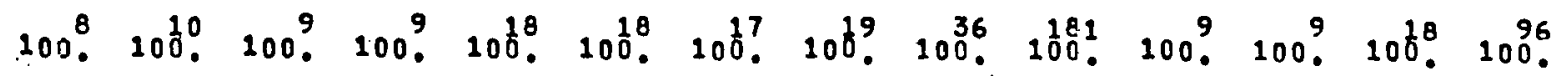

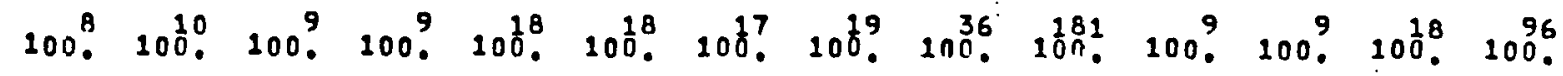

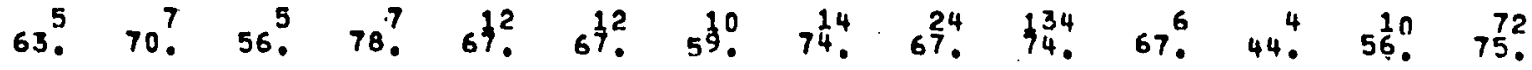
$33^{3} . \quad 30^{3} \cdot \quad 44^{4} \cdot 22^{2} \cdot 33^{6} \cdot 33^{6} \cdot 41^{7} \cdot 26^{5} \cdot 33^{2} \cdot 2^{44} \cdot 33^{3} \cdot 56^{5} \cdot 44^{8} \cdot 25^{4}$. 2.

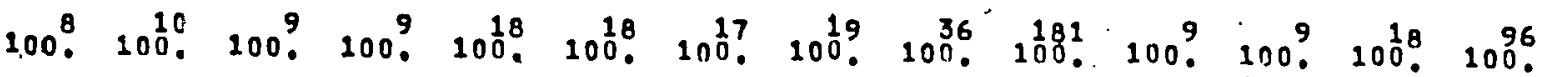

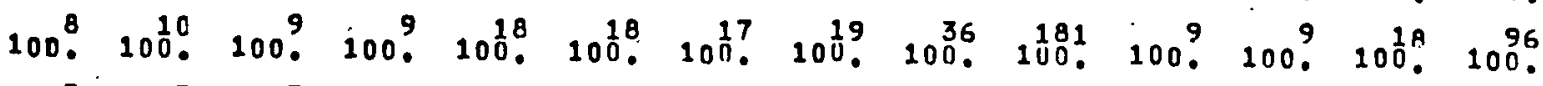

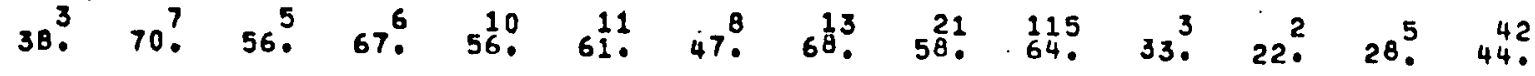

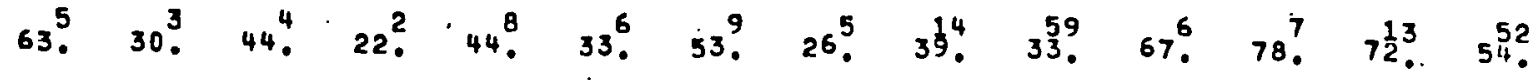
$11.0 \quad 6^{1} \quad 3^{1} \quad 4^{?}$ $2^{2}$

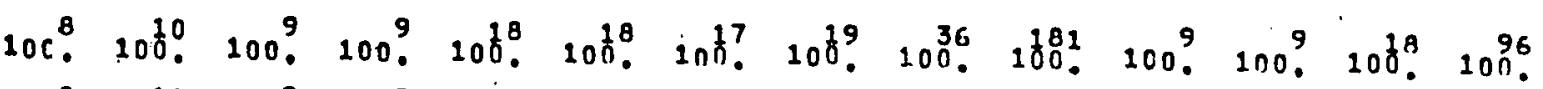

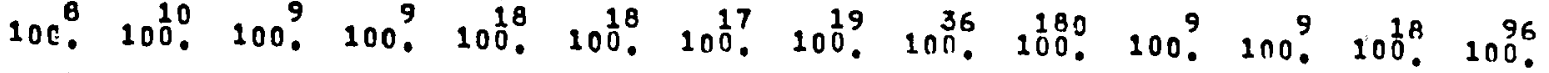

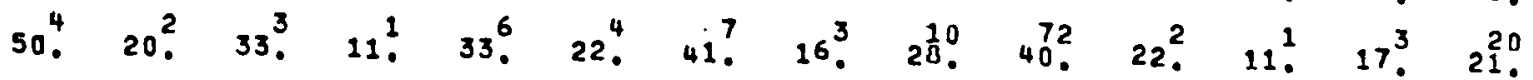

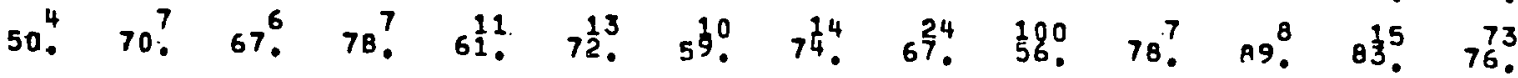

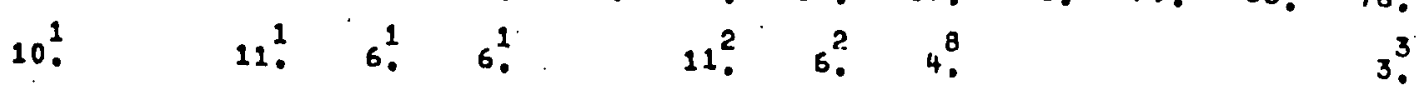

Figure F-1. Biomass Data Tables (continued) 
(OCTOEEA, 1979)

USE OF SELECTED SOLAR INFORMATION SOURCES - CONTINUEO (QUESTION II)

\begin{tabular}{|c|c|c|c|c|c|c|c|}
\hline \multirow[t]{2}{*}{ BTOMASS } & ENERGY & $Y \quad I=O N T I N L$ & JED I & $\begin{array}{l}\text { BIJM } \\
\text { STATE } \\
\text { FO:ST } \\
\text { OF= }\end{array}$ & $\begin{array}{l}\text { BIOM } \\
\text { PRIV } \\
\text { FRSTR }\end{array}$ & $\begin{array}{l}\text { B IOM } \\
\text { FCRST } \\
\text { PFOO } \\
\text { ENG }\end{array}$ & ELLL \\
\hline & & & & $100 ?$ & $100^{9}$ & $100^{8}$ & 1096 \\
\hline $\begin{array}{c}011(8) \\
G P 0\end{array}$ & GOV'T & PRINTING & OFFICE- & $103^{9}$ & $100^{9}$ & $100^{8}$ & 1096 \\
\hline & YES & & & $79^{7}$ & $22^{2}$ & $75^{6}$ & $\begin{array}{r}73 \\
76 .\end{array}$ \\
\hline 2. & NO & & & $11^{1}$ & $78^{7}$ & $25^{2}$ & 24. \\
\hline 8. & DON'T & KINOW & & $11^{1}$ & & & \\
\hline
\end{tabular}

EIOM EALC EDC

$\begin{array}{rr}1009 & 100^{63} \\ 1009 & 1003 \\ 1009 & 790 \\ & 19 \\ & 19 \\ & 1\end{array}$

BIOM ALL ALL
CES CES CES
CEO CO STATE
AGEN AGENT SHEC $100^{9} 1045.100 \%$ 100 ? $100,100^{18}$ $78^{7} .649 .63$ 22. $233^{5} \cdot 17^{3}$ 2.

$100^{9} 1009.103^{\circ} 1096$

$$
1009.200^{63}
$$

$1009.100^{45} \cdot 100^{8}$

$100^{7} 100^{9}$

$\left.20 \mathrm{C}^{9} 100^{9} 101\right)^{\circ} 100^{96}$

$2 \varepsilon^{2} \quad 11^{1}$ 13. $43^{1}$.

$1009.200^{63}$

100 . 100. $100^{8}$.

1. YES

2. NO

8. DON T KNOW

$5 E^{5} \quad 67^{6} \cdot 75^{6} .51^{49}$

$2 \varepsilon^{2} \cdot 22^{2} \cdot 13^{1} \cdot 2^{2}$.

$56.53^{5}$.

$22^{2} . \quad 7.050$.

$44^{4} . \quad 35^{2}$.

67. $87^{39} .50$.

2. $11.27^{3}$

100 ? 100 ?

$43^{3} .233^{3}$.

$57.456^{5}$

11 .

Q121901 TECHNICAL INFORMATION

1. YES

2. NO

8. DONIT KNOW

10). 100 . 100 . $100^{96}$

1019. 100 . $1000^{8} .100^{95}$

$22^{2}, \quad 253^{2} \quad 33^{32}$

$676.1009 .75^{6} . \quad 63^{60}$.

$1: !$

$4^{4}$.

$\begin{array}{rr}1009 & 100^{63} \\ 1009 & 100^{63} \\ 56 . & 44^{28} \\ 44^{4} . & 49^{3} \\ & 6 . \\ & 6 .\end{array}$

$100.2100^{45} \cdot 100^{18}$.

100 . $100^{45}, 10 \frac{10}{8}$.

$22^{2} .12 .50$. 50 .

67. 89.50 \%

11.21.

Figure F-1. Biomass Data Tables (continued) 
IOCTOBER, 1979)

USE OF SELECTED SOLAR INFORM.ATION SOJRCES - CONTINUED IOUESTION 11,

BIOMASS ENERGY (CONTINUEO)

O11 CDdLING NATL SOLAR HEATING +

1. YES

2. NO

8. DON?T KNOW

$\underset{\mathbb{N}}{\mathbb{N}}$

Q111PFERS REGIONAL SOLAR ENERGY

1. YES

2. NO

8. DON'T KNOW

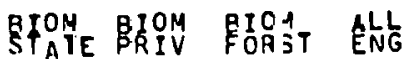

FOAST FRSTR PRO?
OFF

BIOM E EATC

$100^{9} 100 \%$. $100 \%$. $100^{96}$

$100 \% 1003$

1009 . $100^{63}$.

$78^{7} \quad 46^{29}$.

11. $38^{3}$. 36 .

$22^{2} .54$.

89. $67^{6} .63 .50 \%$

11: $22^{2}$.

4.

$1009100^{9}, 100 \% 100^{3}$.

1009.1003

1009 . $100^{63}$.

44. $4 \frac{2}{3}$ ?

$56.56^{54}$.

$3^{2}$.

$1000^{\circ} 1000^{9} .100 .300^{3}$.

$333^{5} \quad 11 \frac{1}{0} \quad 13 \frac{1}{2} 2^{26}$.

67. $78^{7}, 75^{5}, 696$

11. 13! 4.
BIOH ALL ALL
CES CES NES
CU
CGEITT NGENT SPEC

$100^{9} .100 .100^{8}$.

100 . 100. $100^{8}$.

56. $26^{13} .50^{9}$.

$44^{4} .677^{30} \cdot 44^{8}$.

$4^{2} .6$.
AIOH SHAC

OHNER OWNER

100 ? 100 ?

200 ? 100 ?

$29^{2} .233^{3}$.

$71^{5} .67^{6}$.

$100{ }^{7}$ 100?

200? 100 ?

$144^{2}, 22^{2}$

$86^{6} .67^{6}$.

11 .

Figure F-1. Biomass Data Tables (continued) 
(OCTOBER, 1979)

USE OF SELECTED SOLAR INFORMATION SOURCES - CONTINUED (QUESTION 11)

D11(13) US DEPT. OF ENERGY

1. YES

2. NบO

B. DON.T KNOW

BIOMASS ENERGY

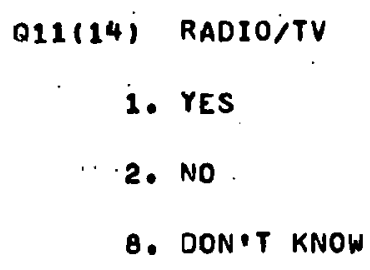

8. DON?T KNOW

Q11 15 SE PER IODICALS

i. YES

2. NO

8. DONIT KNOW

Q1ENTGKONRENTATE OROLAR/

1. YES

2. No

B. DON'T KNOW

BIOM BIOM BIOM BIOM TOTAL TOTAL TOTAL TOTAL TOTAL ALL

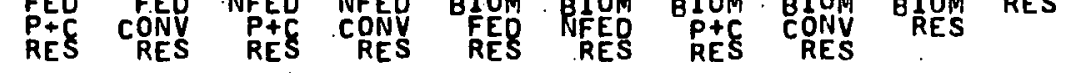

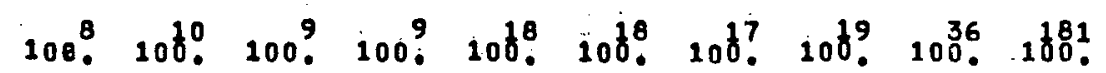

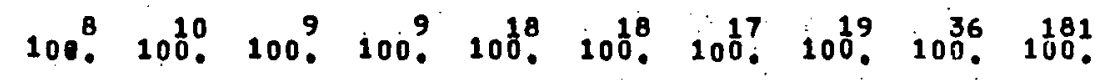

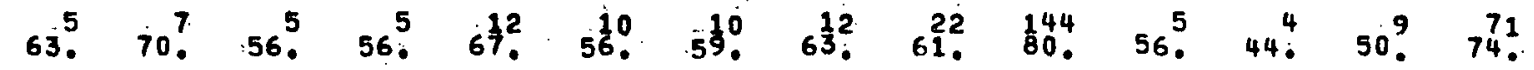

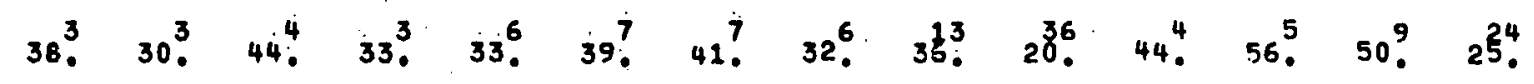

$11^{1} \quad 6^{1} \quad 5^{1} \quad 3^{1} \quad 1^{1}$

BIOM BIOM TOTAL ALL
P+C CONV RIOM MANUF
EUUIP EQUIP MANUF

$100^{9} \quad 100^{9} \quad 108^{8} \quad 100^{96}$

9996

100 . 100 ? $100^{18} .100^{96}$.

1

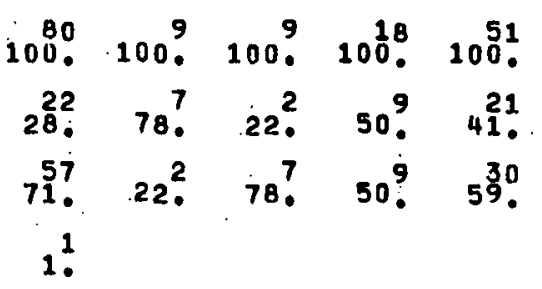

$1009.1009 .1009 .100^{18}, 1006$

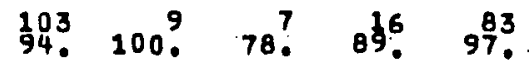

$6^{6} \quad 22^{2} \cdot 11^{2} \cdot 3^{3}$.

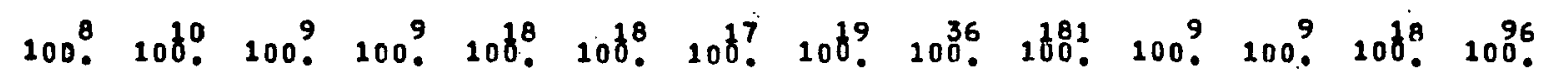

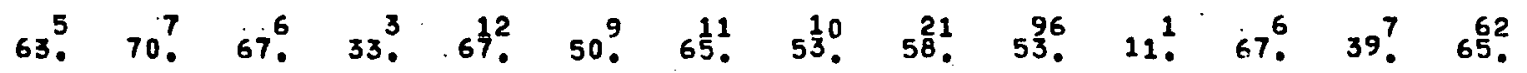

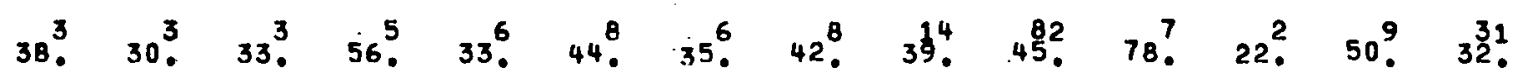

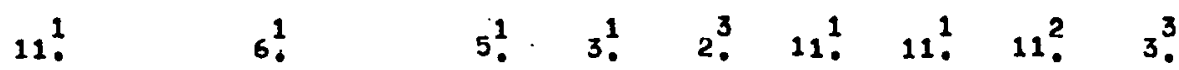

Figure F-1. Biomass Data Tables (continued) 
IOCTOBEP. 1979)

USE OF SELECTEE SOLAR INFORMATION SOURCES - CONTINUED (QUESTIOI: 11.1

BIOMASS ENERGY (CONTINUED)

Q11(13) US DEPT. OF ENERGY

1. YES

2. No

8. DON'T KNOW

Q11(14) RADIO/TV
1. RES
2. NO
O. DON T KNOW

Q1 AETWSPAPERS

1. YES

2. NO

B. DON T KNCW

U11136 IRONMENYATE SOLAR/

1. YES

2. NO

B. DON?T KNON
BION BIOM BIOM ALT ALL
FARE PRIV FORST ENG
FORST FRSTR PROD
OFF

\begin{tabular}{|c|c|c|c|}
\hline 100 & $100^{9}$ & $100^{\circ}$ & 1096 \\
\hline 00 & $100^{9}$ & $100^{\circ}$ & 1006 \\
\hline $00^{5}$ & $22^{2}$ & $50^{4}$. & 630 \\
\hline & $56^{5}$ & 50 . & 35 \\
\hline
\end{tabular}

BIOM EUC EUUC

$$
1000^{9} 100^{63}
$$$$
1009 \text {. } 1003
$$$$
67 . \quad 84 .
$$$$
\text { 33. } 16.10
$$

$\begin{array}{rrr}100^{3} & 100 . & 10 t^{7} \\ 89^{3} & 50^{4} & 59^{\circ} \\ 11^{2} & 50^{4} & 41^{7}\end{array}$

$100 \% 100^{62}$

56. 533 .

44. 458

21

$100 \%$ \% $100 \% 100$ \% 100 \%

100.1003

89. $97^{61}$.

11 . $3^{2}$

$2^{1}$
BIOM ALL ALL
CES CES CCES
COONT CO SIIATE
AGENT BEENT SPEC

$100^{\circ} 10 \mathrm{C}^{5} 100^{10}$

$100^{9} .1 c^{45} .10 \delta^{8}$

78 . 5 I. $^{3} \xi^{6}$.

22. $44^{2} 0 \quad 11^{2}$

4.2

$100^{9} \cdot 100^{45} 106^{8}$

56. 412. $61^{11}$

44. 5\%. 39?.

$2^{1}$

100 . 100. 100 .

89. $67^{\circ} .100^{18}$

$11.13^{16}$
OIOM SHAC OWPER 8WNER 100 ? 100 ? 100 ? 100 ?

$43^{3} \quad 33^{3}$.

$57^{4} .67^{6}$.

100 ? 100 ?

43. $22^{2}$.

37. 78 ?

100? 100 ? 100 ? 100 ?

\begin{tabular}{|c|c|c|c|c|c|c|c|c|}
\hline $100 \%$ & $100^{9}$ & $100^{3}$ & $\begin{array}{r}96 \\
100\end{array}$ & 1009 & 1063 & $100^{9}$ & $\begin{array}{r}455 \\
1.005\end{array}$ & $138^{\circ}$ \\
\hline $56 !$ & $33^{3}$ & $38^{3}$ & 439. & $89^{8}$ & $\begin{array}{r}42 \\
67\end{array}$ & $44^{4}$ & $\frac{16}{36 .}$ & $199^{7}$ \\
\hline $44^{\circ}$ & $67^{6}$ & 63 & $\begin{array}{r}56 \\
58 .\end{array}$ & $11 !$ & 331 & $44^{4}$. & 6.7 .7 & 611. \\
\hline
\end{tabular}

$\begin{array}{rr}100 ?^{7} & 100 ? \\ 71^{5} & 33^{3} \\ 29 & 6 \\ & 67^{6}\end{array}$

Figure F-1. Biomass Data Tables (continued) 
(OCTOBER. 1979)

USE OF. SELECTED. SOLAR INFORMATION SOURCES - CONTINUEO (QUESTION 11)

EIOMASS ENERGY BIOM BIOM RIOM AIOM TOTAL TOTAL TOTAL TOTAL TOTAL ALL P+C CONV P+E CONV FED NFED P+E CONV

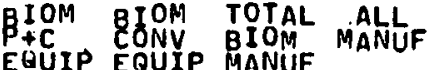
EGUYP EDUIP MANU

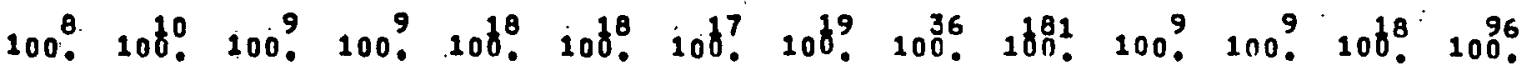
Q11(17) STATE ENERGY OR SOLAR
OFFICES

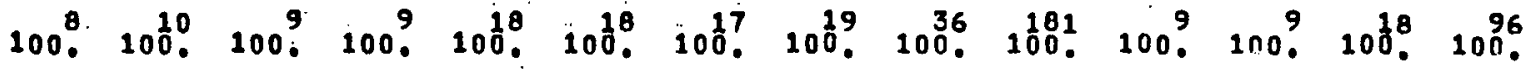

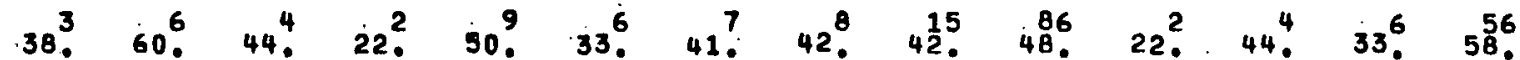
1. YES

2. No

8. DON T KNOW

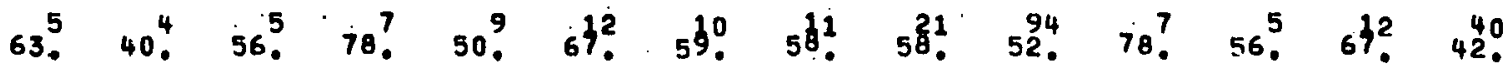

Q1ZSIRE GOVHER STATEE SOURE 1. YES

点

2. No

8. DON'T KNOW

Q1 SOETETY INTLES SOLAR ENEREY

1. YES

2. NO

B. DON?T KNOW

Q11120I SOLAR ENERGY
INOUSTRIES ASSOE.-SEIA

1. YES

2. NO

B. DON'T.KNOW

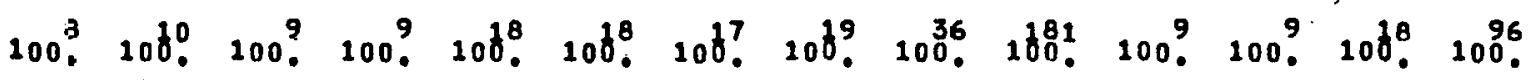

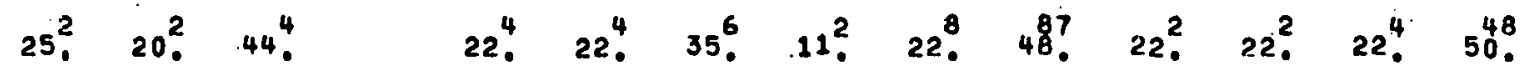

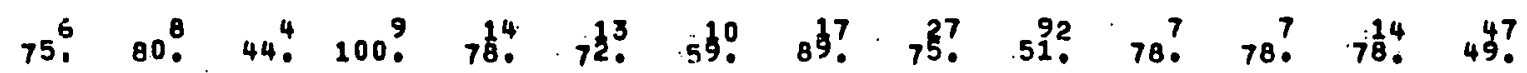

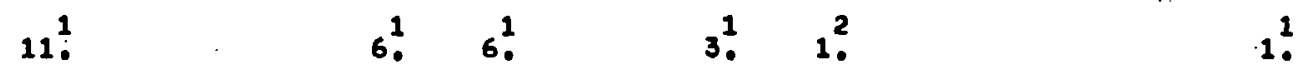

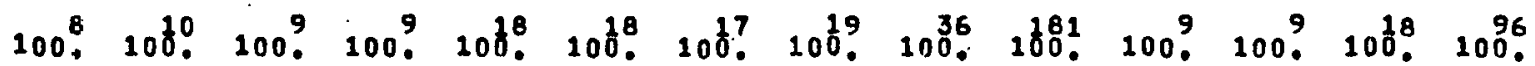

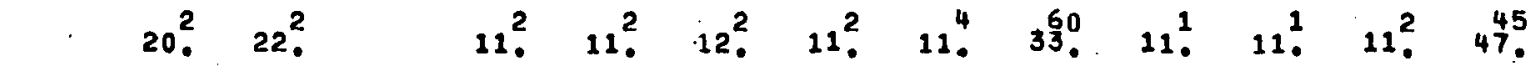

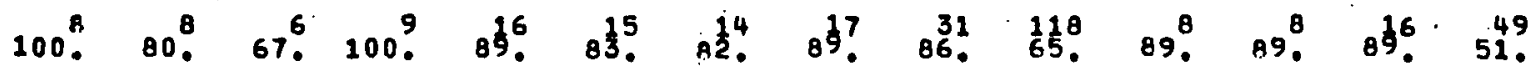
$11^{1} \quad 6^{1}: 6^{1} \quad 3^{1} \quad 2^{3}$

Figure F-1. Biomass Data Tables (continued)

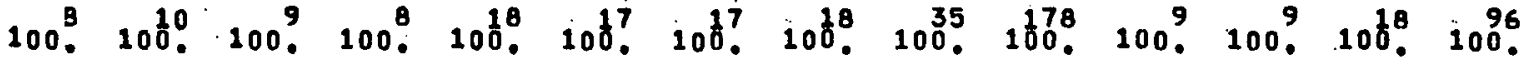

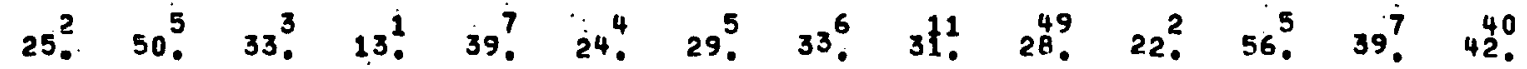

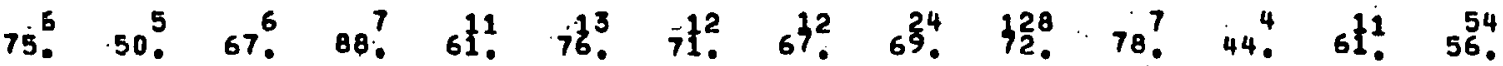
1 . 
IOCTOBER, 19791

USE OF SELECIED SOLAR INFORMATION SOURCES - CONTINUEO (QUESTION 11 )

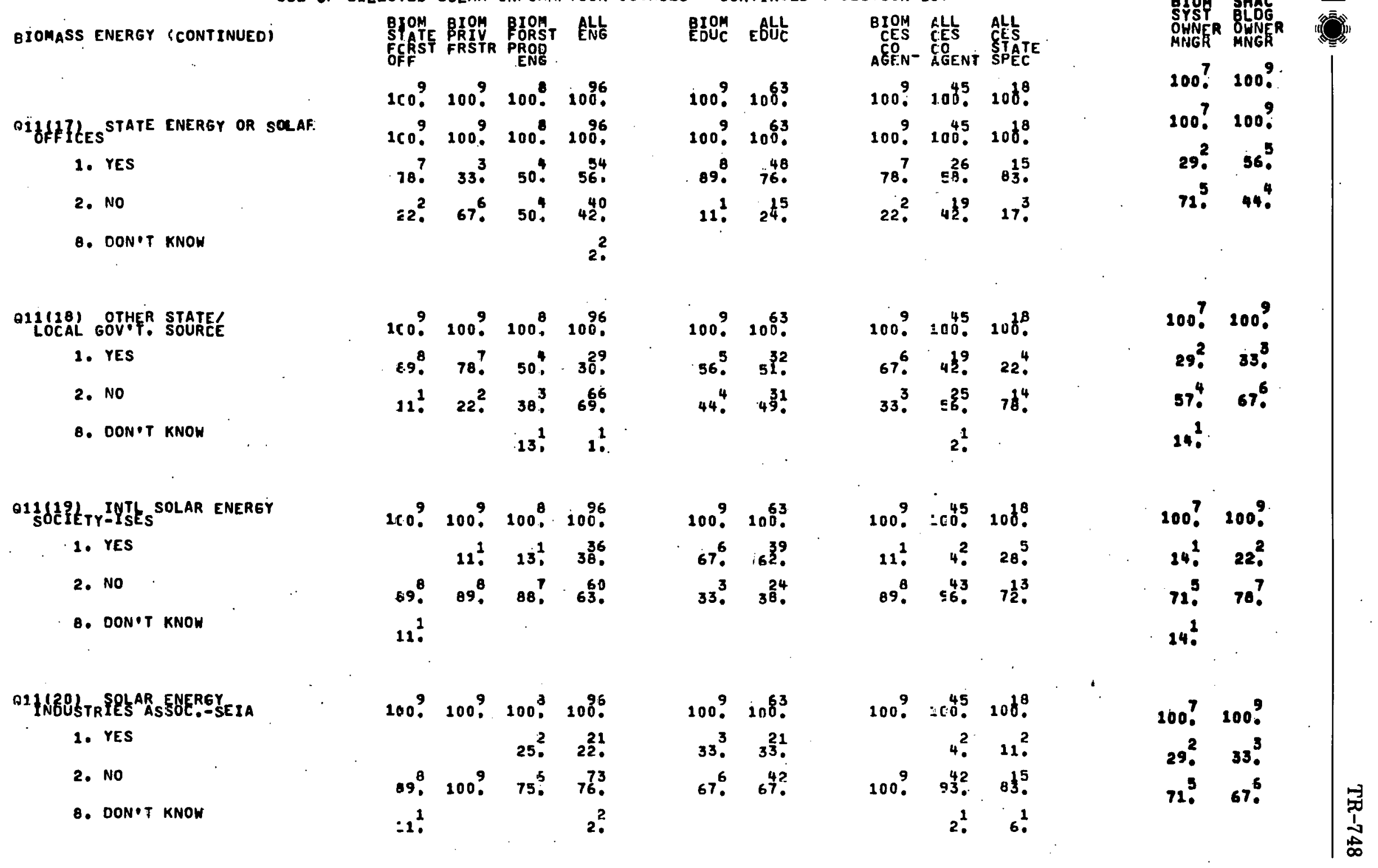

Figure F-1. Biomass Data Tables (continued) 
IOCTOBER, 19791

USE OF SELECTED SOLAR INFORMATION SOURCES - CONTINUED (QUESTION 11)

BIOMASS ENERGY

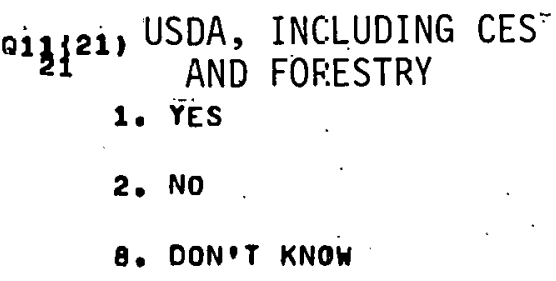

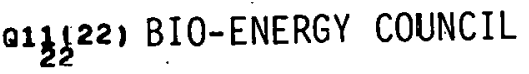
1. YES

里

2. No

B. DON?T KNOH
BIOM. BIOM BIOM BIOM TOTAL TOTAL TOTAL TOTAL TOTAL P+C. COND P+C CONV BFE NFE RES RES RES CONV BRES

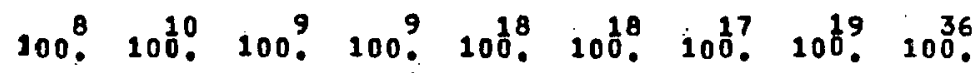

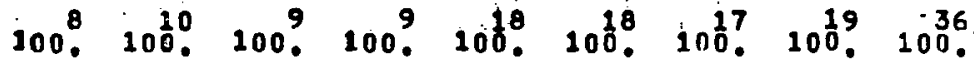

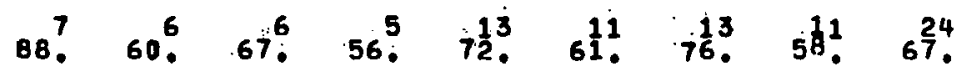

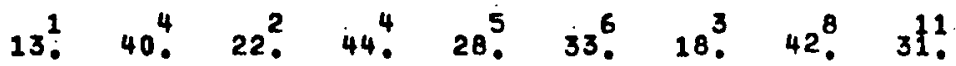
$11^{1} \quad 6^{1} \quad 6^{1} \quad 3^{1}$

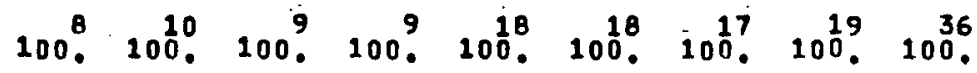

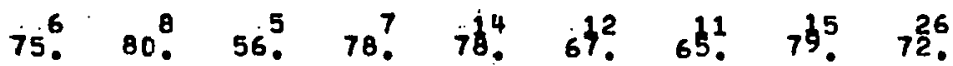

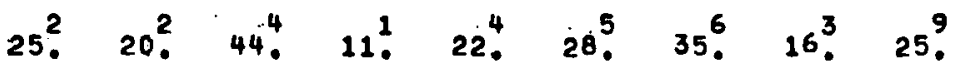
11 . $\quad 6^{1} \quad 5^{1} \quad 3^{1}$
BIOM BIOM TOTAL EQUIP CONU RAPM 100 . $1000^{9} 100^{8}$. $100^{9}, 100^{9}, 100^{18}$. 44. $44^{4} \cdot 44^{8}$. 56. $56^{5} .56^{\circ}$.

$1000^{9} 1000^{9}, 100^{18}$. 11 . $11^{1} 11^{2}$. $899^{8}$ 89. $89^{6}$.

Q1 $\frac{1}{24}(24)$ QUESTIONNAIRE SOURCE

1. YES

2. NO

- DON?T kNOW

Figure F-1. Biomass Data Tables (continued) 
(OCTOBER, 19791

USE OF SELECTED SOLAR INFORMATION SOURCES - CONTINUED (OUESTION 11 )

BIOMASS ENERGY (CONTINUED)

Q11 21, USDA, INCLUDING CES AND FORESTRY

1. YES

2. NO

8. DON'T KNOW

O1£(22) BIO-ENERGY COUNCIL
1. YES
2. NO
8. DON T KNOW

BIOM ERTL ENIC

BICM BIOM EIOM
SITIE PRIV FOLL
FOEST FRSTR FRGD ENG
OFF

$\begin{array}{rrr}100^{9} & 100^{9} & 100^{8} \\ 100^{9} & 100^{9} & 100^{8} \\ 85^{8} & 78^{7} & 38^{3} \\ 11^{2} & 22^{2} & 63^{5}\end{array}$

$11^{2} \cdot 22^{2} \cdot 63^{5}$

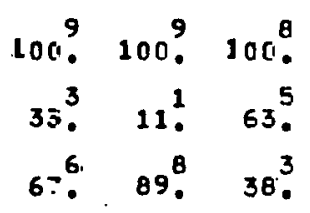

$67^{6} .89^{8} .38^{3}$.

100 ?

100 ?

89.

11 .

BIOM ALL ALL
CES CES CCES
CO CO ST
AGENT AGENT SPEC

100 . 100. inf?

$100.100 .100^{10}$

100998.947

2. 6 ?

$01 \frac{1}{2} \frac{1}{23} ;$ WOOD ENERGY INSTITUTE
1. YES
2. NO
O. DONTT KNON

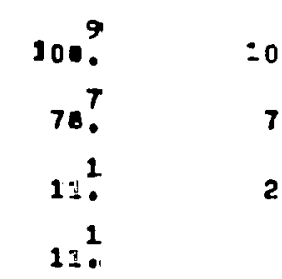

$100 \%$

${ }_{24}^{11}(24)$ STATE DEPARTMENT OF AGRICULTURE
1. YES
2. NO
๑. DON'T KNOW

$$
\begin{array}{r}
1009 \\
33 . \\
67^{6} .
\end{array}
$$

Figure F-1. Biomass Data Tables (continued; 


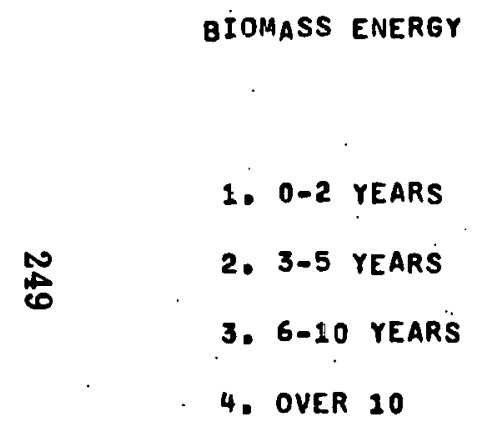

DON'T KNOH/NA
(OCTOBER, 1979)

YEARS IN CURRENT PROFESSION (OUESTION D2B)

BIOM BIOM BIOM BIOM TOTAL TOTAL TOTAL TOTAL TOTAL ALL BIOM BIOM TOTAL ALL

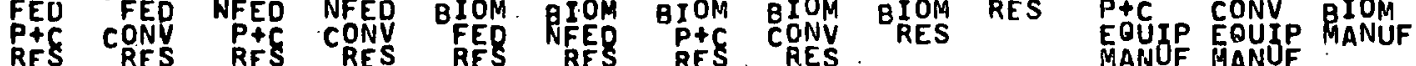

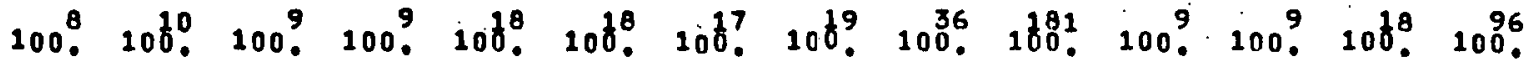

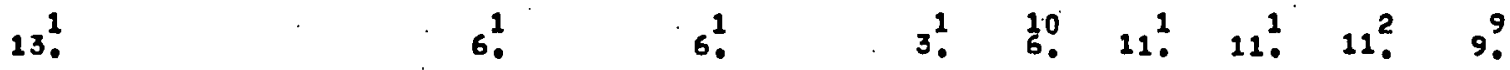

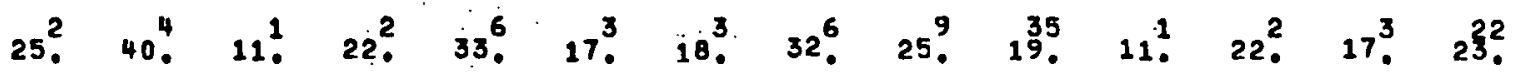

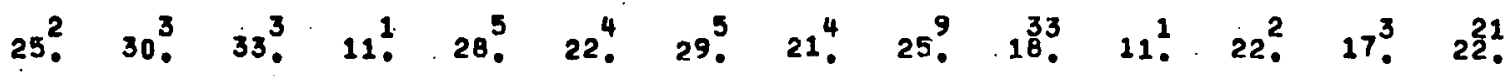

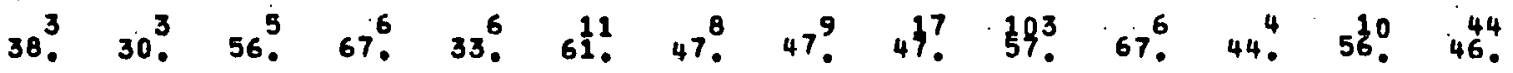

Figure F-1. Biomass Data Tables (continued) 
Figure F-1. Biomass Data Tables (continued) 
$(2$

BIOMASS ENERGY

i. res BELONG, NAME

હ

2. YES BELONG.

3. NO. DON T BELONG

DON T KNOW/NA

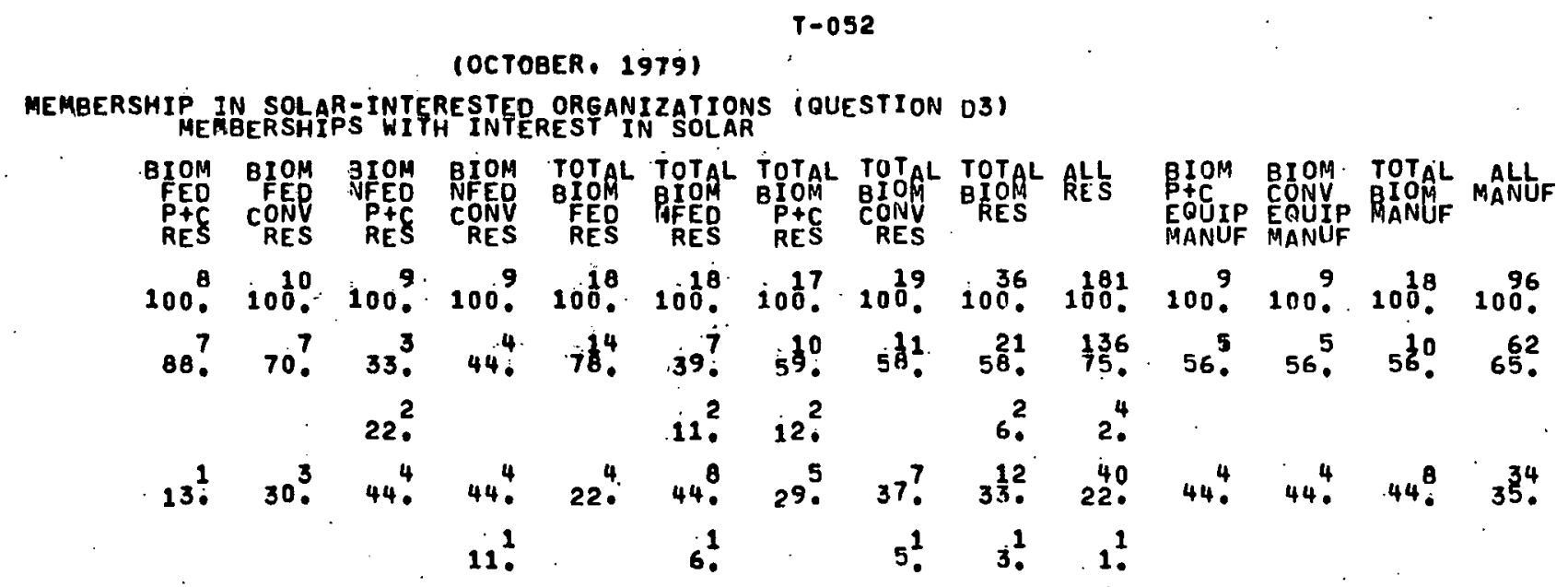

Figure F-1. Biomass Data Tables (continued) 


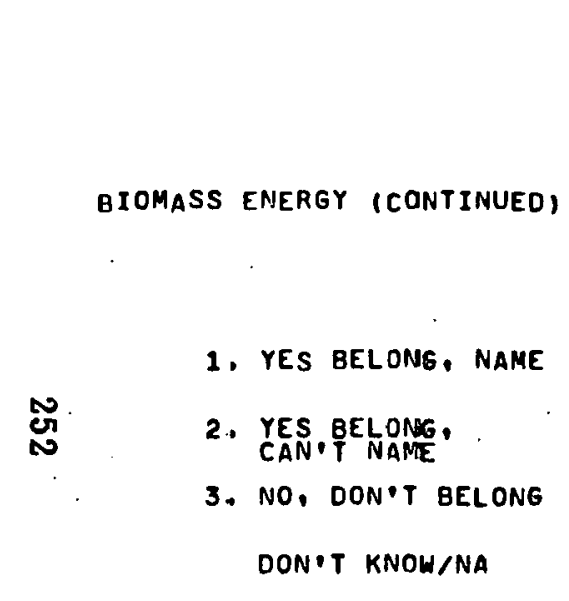

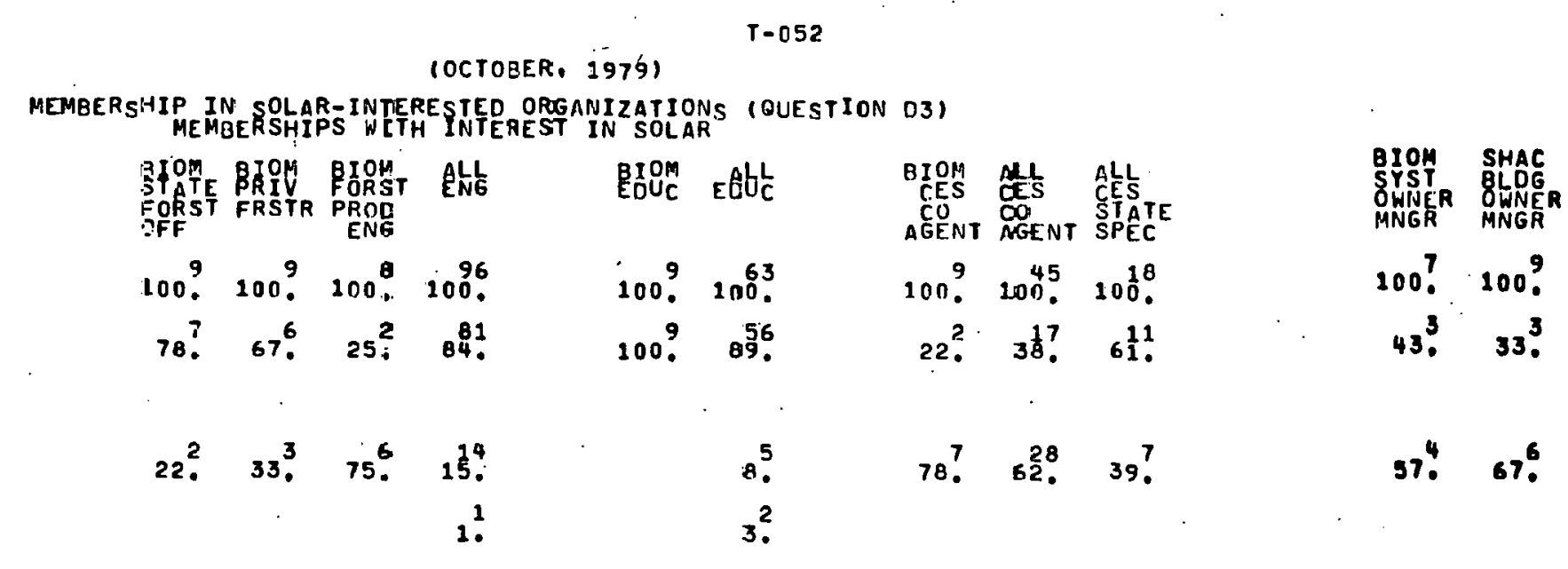

Figure F-1. Biomass Data Tables (continued) 
Figure F-1. Biomass Data Tables (continued) 
Figure F-1. Blomass Data Tables (concluded) 


\begin{tabular}{|c|c|c|}
\hline $\begin{array}{l}\text { Document Control } \\
\text { Page }\end{array}$ & $\begin{array}{l}\text { 1. SERI Report No. } \\
\text { TR-751-748 }\end{array}$ & 3. Recipient's Accession No. \\
\hline \multirow{2}{*}{\multicolumn{2}{|c|}{$\begin{array}{l}\text { 4. Title and Subtitle } \\
\text { Biomass Energy Systems Information User Study }\end{array}$}} & $\begin{array}{l}\text { 5. Publication Date } \\
\text { January } 1981 \\
\end{array}$ \\
\hline & & 6. \\
\hline $\begin{array}{l}\text { 7. Author(s) } \\
\text { W. W. Belew, B. }\end{array}$ & L. Wood, T. L. Marle, C. L. Reinhardt & 8. Performing Organization Rept. No \\
\hline \multirow{2}{*}{\multicolumn{2}{|c|}{$\begin{array}{l}\text { 9. Performing Organization Name and Address } \\
\text { Solar Energy Research Institute } \\
1617 \text { Cole Boulevard } \\
\text { Golden, Colorado } 80401\end{array}$}} & $\begin{array}{c}\text { 10. Project/Task/Work Unit No. } \\
8420.11\end{array}$ \\
\hline & & $\begin{array}{l}\text { 11. Contract (C) or Grant (G) No. } \\
\text { (C) } \\
\text { (G) }\end{array}$ \\
\hline \multirow{2}{*}{\multicolumn{2}{|c|}{ 12. Sponsoring Organization Name and Address }} & $\begin{array}{l}\text { 13. Type of Report \& Period Covered } \\
\text { Technical Report }\end{array}$ \\
\hline & & 14. \\
\hline
\end{tabular}

15. Supplementary Notes

16. Abstract (Limit: 200 words) This report describes the results of a series of telephone interview with groups of users of information on biomass energy systems. These results, part of a larger study on many different solar technologies, identify types of information each group needed and the best ways to get information to each group. The report is 1 of 10 discussing study results. The overall study provides baseline data about information needs in the solar community. It covers these technological areas: photovoltaics, passive solar heating and cooling, active solar heating and cooling, biomass energy, solar thermal electric puwer, solar industrial and agricultural process heat, wind energy, ocean energy, and solar energy storage. An earlier study identified the information user groups in the solar community and the priority (to accelerate solar energy commercialization) of getting information to each group. In the current study only high-priority groups were examined. Results from 12 biomass groups of respondents are analyzed in this report: Federally Funded Researchers (2 groups), Nonfederally Funded Researchers (2 groups), Representatives of Manufacturers (2 groups), Representatives of State Forestry Offices, Private Foresters, Forest Products Engineers, Educators, Cooperative Extension Service County Agents, and System Managers. The data will be used as input to the determination of information products and services the Solar Energy Research Institute, the Solar Energy Information Data Bank Network, and the entire information outreach community should be preparing and 17. Document Analysis disseminating.

a. Descriptors

Biomass:T1 ; Cost ; Data Acquisition : Data Analysis ; Data Base Management

Data Compilation ; Evaluated Data ; Information Needs:Q1 ; Marketing Research ;

b. Identifiers/Open-Ended Terms Sampling; Site Selection; Solar Industry ; Telephones ;

Communications; Data ; Energy Sources ; Industry ; Information ; Management ;

Numerical Data ; Renewable Energy Sources

c. UC Categories

$58 \mathrm{c}, 51 \mathrm{a}$

18. Availability Statement

National Technical Information Service

U.S. Department of Commerce

5285 Port Royal Road

Springfield, Virginia 22161

19. No. of Pages

254

20. Price

Form No. 8200-13 (6-79)

$\$ 10.75$ 